UNIVERSIDADE DE SÃO PAULO

FACULDADE DE EDUCAÇÃO

SIMONE RODRIGUES BATISTA

\title{
UM DIÁLOGO ENTRE COMUNICAÇÃO E EDUCAÇÃO: A FORMAÇÃO INICIAL DE PROFESSORES EM SOCIEDADES MIDIÁTICAS
}

SÃo PAULO 


\section{UM DIÁLOGO ENTRE COMUNICAÇÃO E EDUCAÇÃO: A FORMAÇÃO INICIAL DE PROFESSORES EM SOCIEDADES MIDIÁTICAS}

Tese apresentada à Faculdade de Educação da Universidade de São Paulo como parte dos requisitos para a obtenção do título de Doutor em Educação.

Área de concentração: Didática, Teorias de Ensino e Práticas Escolares

Orientadora: Profa. Dra. Maria Isabel de Almeida

Universidade de São Paulo

São Paulo

2012 
AUTORIZO A REPRODUÇÃO E DIVULGAÇÃO TOTAL OU PARCIAL DESTE TRABALHO, POR QUALQUER MEIO CONVENCIONAL OU ELETRÔNICO, PARA FINS DE ESTUDO E PESQUISA, DESDE QUE CITADA A FONTE.

Catalogação na Publicação Serviço de Biblioteca e Documentação

Faculdade de Educação da Universidade de São Paulo

$371.12 \quad$ Batista, Simone Rodrigues

B333d Um diálogo entre comunicação e educação: a formação inicial de professores em sociedades midiáticas / Simone Rodrigues Batista; orientação Maria Isabel de Almeida. São Paulo: s.n., 2012.

219 p. il.; grafs.; tabs.

Tese (Doutorado - Programa de Pós-Graduação em Educação. Área de Concentração: Didática, Teorias de Ensino e Práticas Escolares) - - Faculdade de Educação da Universidade de São Paulo.

1. Formação de professores 2. Comunicação (Produção) 3. Educomunicação I. Almeida, Maria Isabel de, orient. 


\section{Folha de Aprovação}

Simone Rodrigues Batista

\section{Um diálogo entre comunicação e educação: a formação inicial de professores em sociedades midiáticas}

Tese apresentada à Faculdade de Educação da Universidade de São Paulo como parte dos requisitos para a obtenção do título de Doutor em Educação.

Área de concentração: Didática, teorias de ensino e práticas escolares.

Orientadora: Profa. Dra. Maria Isabel de Almeida.

Aprovado em: de de 2012.

\section{Banca Examinadora}

Prof. Dr.

Instituição: Assinatura

Prof. Dr.

Instituição: Assinatura

Prof. Dr.

Instituição: Assinatura

Prof. Dr.

Instituição: Assinatura

Prof. Dr.

Instituição: Assinatura 
A Mariazinha Fusari

Por estar sempre presente,

$\mathrm{Na}$ dimensão de quem ama a humanidade

Aos meus pais, Silvio e Mércia,

Pela parceria e amor cotidianos 


\section{AGRADECIMENTOS}

À minha orientadora Maria Isabel de Almeida, pela cumplicidade na produção deste texto, pela abertura ao diálogo, pela leveza/seriedade com que trata a educação e a pesquisa.

Às professoras doutoras Eliany Salvatierra e Maria Amélia Santoro Franco, pela colaboração preciosa no momento da banca de qualificação.

Ao professor José Cerchi Fusari, pelo incentivo e leitura cuidadosa dos meus escritos e por me lembrar sempre que a vida é muito além disso tudo.

Ao meu diretor Adalto, pela compreensão da importância da pesquisa acadêmica.

À Sandra, pelo incentivo a continuidade dos meus estudos e da minha trajetória de pesquisa.

À Luciana, por me incentivar ao ingresso no doutorado, me acompanhando desde o início da elaboração do meu projeto de pesquisa.

À chefe do Departamento Pedagógico da Secretária de Educação de Santos, Selma Lara, por compreender a importância da pesquisa, permitindo flexibilidades nos meus horários de trabalho para uma maior dedicação a este trabalho.

Ao Gérson, pela paciência e competência com que me ajudou a elaborar os gráficos.

Ao Rodrigo, pela sua generosidade em ajudar, doando seu tempo de forma carinhosa e competente e pelas dicas e ideias quanto ao meu objeto de estudo e as formas de encaminhar a pesquisa.

Às professoras e professores da rede pública de Santos, que gentilmente responderam meus questionários.

Às equipes técnicas das escolas da rede municipal de ensino de Santos que permitiram meu trabalho junto aos docentes nas horas de trabalho pedagógico.

À Maria Amélia pelas sugestões valiosas de leitura e delimitação do meu objeto de estudo.

Aos colegas do GEPEFE, pelas valiosas contribuições quanto à minha pesquisa, com leituras cuidadosas do meu texto.

À Eliany, pelos papos no Skype, pelas sugestões e leitura, por partilhar sonhos educomunicadores comigo há muitos anos. 
À Mariasinha, que de onde quer que esteja, me ouve, me dá dicas, me acompanha na minha trajetória.

Ao professor Adilson Citelli, que me deu as primeiras sugestões quanto ao caminho a ser trilhado, pela sua dedicação a educomunicação.

Ao professor Eneus, meu primeiro professor no doutorado, com suas contribuições quanto às possibilidades para meu objeto de estudo.

Ao professor Clóvis de Barros, pela suas primeiras orientações, sempre profundas e precisas.

À Secretária Cristiane, com suas contribuições quanto à digitação e formatação de tabelas.

Em especial, as minhas colegas de doutorado, que partilharam angústias e sonhos comigo: Alda e Lygia.

À amiga Juliana, pela ajuda na elaboração do abstract.

A Deus, por ser uma presença que envolve, conforta, anima. 


\section{Epígrafe central}

Cenas de uma escola:

Cadeiras jogadas...

Gritos... vozes que se elevam...

Para, menino! Fiquem quietos todos vocês!

A não possibilidade do diálogo...

A perda de uma relação de alteridade...

Escola... tensão....

Escola... caminhos possíveis...

“O inferno dos vivos não é algo que será; se existe, é aquele que já está aqui, o inferno no qual vivemos todos os dias, que formamos estando juntos. Existem duas maneiras de não sofrer. A primeira é fácil para a maioria das pessoas: aceitar o inferno e tornar-se parte deste até o ponto de deixar de percebê-lo. A segunda é arriscada e exige atenção e aprendizagem contínuas: tentar saber reconhecer quem e o que, no meio do inferno, não é inferno, e preservá-lo, e abrir espaço." (Ítalo Calvino. Cidades Invisíveis) 


\section{RESUMO}

BATISTA, Simone Rodrigues. Um diálogo entre comunicação e educação: a formação inicial de professores em sociedades midiáticas. São Paulo, 2011. Tese de Doutorado.

Faculdade de Educação da Universidade de São Paulo

Esta pesquisa toma como objeto de investigação a formação inicial de professores em sua relação com a sociedade midiática atual, que exige novas habilidades dos professores para o trabalho com crianças nascidas e criadas na era tecnológica, onde a escola não é mais o único espaço de aprendizagem e socialização. Por considerar que a sociedade atual passa por transformações constantes e aceleradas, que impactam não somente a tecnologia, mas também a forma de se produzir cultura e se relacionar socialmente, tem-se como pressuposto que a escola, os professores e os alunos vem sendo impactados por estas transformações, o que coloca novas dificuldades para o processo de ensino e aprendizagem. A pesquisa tem como objetivo analisar a formação de professores em sua relação com as questões comunicacionais midiáticas e quanto ao preparo para um trabalho com mídias nas escolas. Em sua dimensão empírica, de base qualitativa, analisou os quadros curriculares de seis cursos de Pedagogia da cidade de Santos, na interface entre educação e comunicação. Também foram analisados questionários aplicados a professores de oito escolas de ensino fundamental I da rede pública municipal de Santos, que avaliaram suas percepções a respeito de suas práticas pedagógicas, em especial no que tange ao trabalho com novas mídias em suas aulas. Os resultados contribuíram para sustentar a tese apresentada sobre a necessidade de se reorientar a formação inicial de professores, em decorrência de novas demandas sociais, educacionais e culturais, uma vez que se têm cursos de formação que não estão preparando os futuros professores para um trabalho com alunos que vivem em sociedades midiáticas, com novas formas de aprendizagem e socialização. As conclusões apontam na direção de que a escola e os professores precisam se assumir como produtores sociais de comunicação, estreitando o diálogo entre as áreas de comunicação e educação.

PALAVRAS - CHAVE: 1. Formação inicial de professores; 2. Produção social de comunicação; 3. Mediação docente; 4. Educomunicação. 


\begin{abstract}
BATISTA, Simone Rodrigues. A dialog between communication and education: the initial education of professors in Mediatic societies. São Paulo, 2011. Doctorate thesis.
\end{abstract}

University of São Paulo - Education program.

This research has the objective of investigating the initial education of professors in relation to today's mediatic society that demands new skills from them for the work with kids born and raised in this era of technology, where school is no longer the only place for learning and socializing. For considering that today's society is undergoing constant and quick transformation, that impact not only technology, but also the way of producing culture and social relations, presupposes that the school, teachers and students are being impacted by these transformations, which brings new challenges for the process of teaching and learning. The research brings to analysis the formation of teachers in relation to the mediatic communication questions and the preparation of work with media in the schools. In its empirical dimension, qualitative base, it's been analyzed the curriculum of six Pedagogical courses in the city of Santos, in the interface between education and communication. It has also been analyzed the questionnaires applied to teachers in eight pre and junior high schools from the public system that evaluated their perceptions regarding their pedagogical practices, in special to the work with new media in their classrooms. The results contributed to sustain the present thesis about the need to reorient the initial education of professors, in regards to the new social, educational and cultural demands, once there are courses that are not preparing future professors to work with students who live in mediatic societies, with new ways of learning and socializing. The conclusions point to the direction in which schools and professors need to assume themselves as social communication producers, narrowing the dialog between the communication and education areas.

KEY WORDS: - 1. Inicial education for professors; 2. Social education production; 3. Teaching mediation ; 4. Educomunication 


\section{Lista de Tabelas}

Tabela 1. Disciplinas ofertadas na interface entre educação e comunicação. 121

Tabela 2. Diversificação de Metodologias, periodicidade e utilização de materiais. 155

Tabela 3. Relação Mídias e educação, periodicidade e utilização de materiais pelos professores.

\section{Lista de Gráficos}

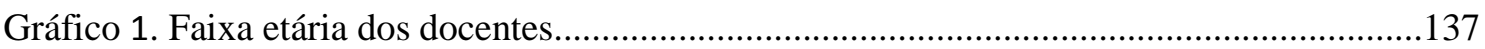

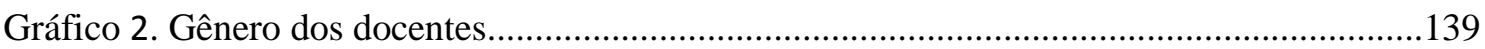

Gráfico 3. Local da formação inicial dos docentes..................................................................... 140

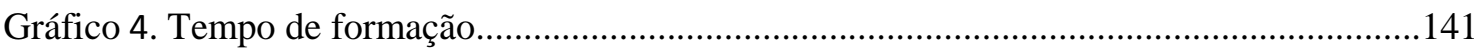

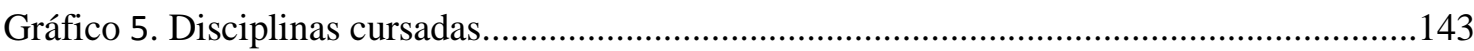

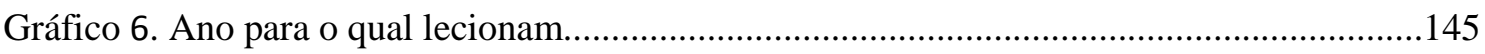

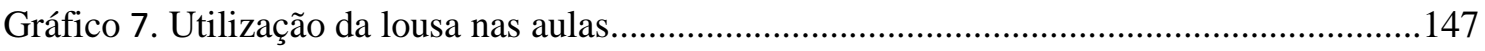

Gráfico 8. Utilização de programas de TV nas aulas...................................................................148

Gráfico 9. Periodicidade do uso de materiais em aula................................................................150

Gráfico 10. Periodicidade de uso de recursos variados nas aulas..............................................151

Gráfico 11. Programas de TV colaboram com as aulas?..............................................................161

Gráfico 12. Sondagem de programas de TV pelos docentes.......................................................165

Gráfico 13. Professores e discussão de programas de TV com alunos........................................167

Gráfico 14. Preparo dos professores para trabalho com mídias...................................................169 


\section{SUMÁRIO}

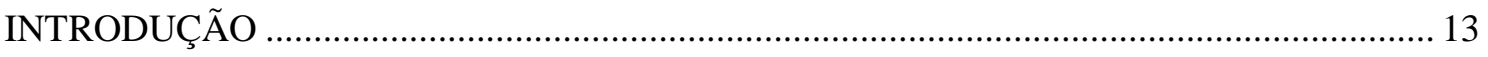

A construção da pesquisadora e da pesquisa: a dialeticidade do movimento ........................... 13

O caminho da pesquisa: múltiplos lugares, tempos e olhares .............................................. 29

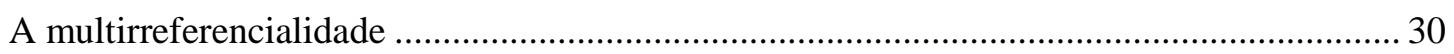

CAPÍTULO 1. UM MUNDO TECNOLOGIZADO E MIDIÁTICO: CRIANÇAS E EDUCAÇÃO ESCOLAR EM NOVOS CONTEXTOS DE COMUNICAÇÃO.......................... 39

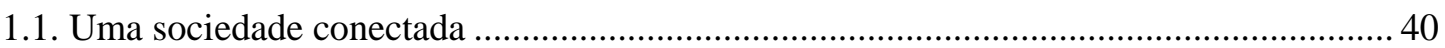

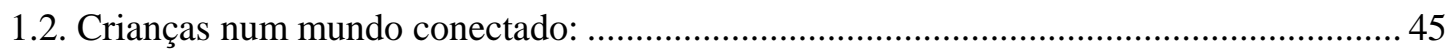

1.3. Pensando a escola num mundo tecnologizado e midiático: ............................................. 49

CAPÍTULO 2 - DOCENTES E SOCIEDADES MIDIÁTICAS: PENSANDO A FORMAÇÃO

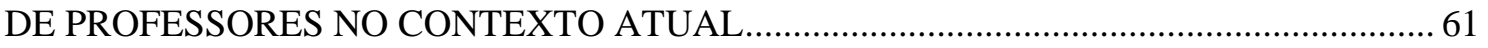

2.1 Retratos da rede municipal de ensino de Santos, retratos de professores: .......................... 62

2.2 Pensando a legislação de formação inicial de professores: .................................................. 67

2.2.1. As normas legais para formação de professores ........................................................... 69

2.3 A legislação de formação de professores e a relação entre educação e comunicação:...... 74

2.4 Os processos de formação de professores e a constituição da identidade docente: ........... 77

2.5 A formação inicial docente e as instituições formadoras: .................................................... 85

2.6 Os quadros curriculares dos cursos de Pedagogia da cidade de Santos e sua relação com a

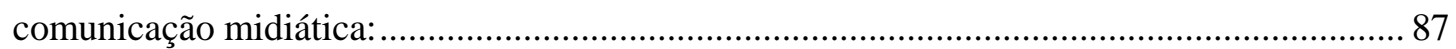

CAPÍTULO 3 - FORMAÇÃO DE PROFESSORES E INTERFACES COM PROCESSOS

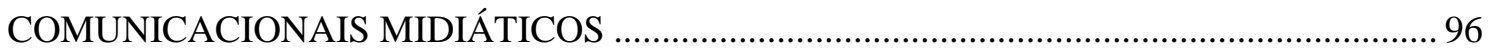

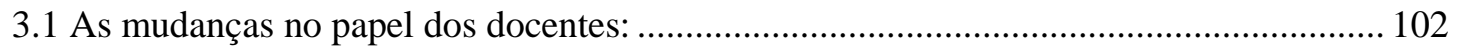

3.2 Processos comunicacionais e educacionais: a relação com a formação e trabalho docente nas escolas:

3.3 O que retratam as ementas das disciplinas relacionadas à área de comunicação nos cursos de formação inicial de docentes

3.3.1 Refletindo sobre as ementas e propostas das disciplinas: ........................................ 120

3.4 Pensando novos cenários para a educação e a formação de professores........................... 127

CAPÍTULO 4. FORMAÇÃO DE PROFESSORES E PRÁTICAS DOCENTES: OS DADOS

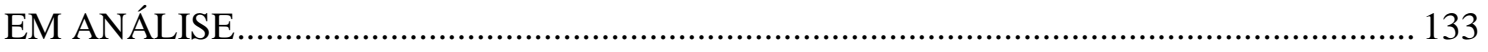

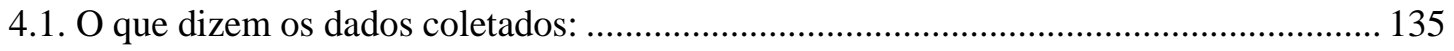

4.1.1. Contextualizando quem são os docentes da pesquisa: ............................................ 137

4.2. Percepção dos professores quanto às suas práticas docentes em relação às mídias ........ 154

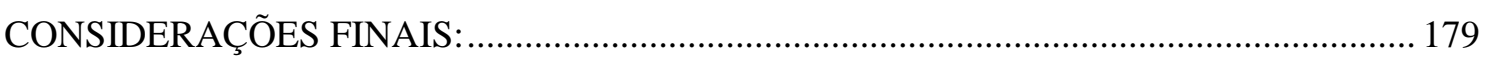

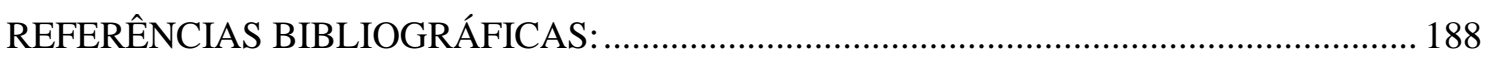




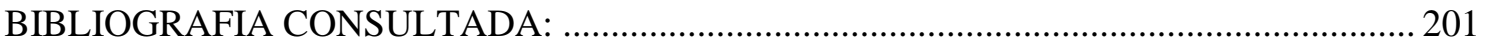

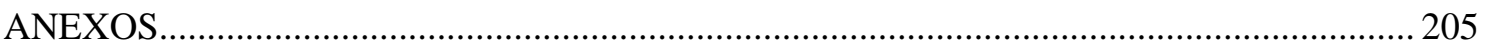

ANEXO A - Matriz Curricular da Instituição UNILUS ......................................................... 206

ANEXO B - Matriz Curricular da Instituição UNIMES ........................................................ 207

ANEXO C - Matriz Curricular da Instituição UNIMONTE ................................................... 208

ANEXO D - Matriz Curricular da Instituição UNIP ............................................................. 210

ANEXO E - Matriz Curricular da Instituição UNISANTA ……………………................. 212

ANEXO F - Matriz Curricular da Instituição UNISANTOS ................................................ 214

APÊNDICE - Questionário aplicado aos docentes da Rede Municipal de Ensino de Santos... 216 


\section{INTRODUÇÃO}

\section{A construção da pesquisadora e da pesquisa: a dialeticidade do movimento}

Trabalho com formação inicial de professores há aproximadamente 21 anos. Iniciei minha carreira docente trabalhando nos chamados cursos de Magistério, que formavam professores no nível médio. Por volta do ano de 1996 comecei a trabalhar com formação inicial de professores em nível superior, em uma faculdade privada. Assim, durante 15 anos, venho percorrendo um caminho como professora no ensino superior, em cursos de Pedagogia. Esta trajetória profissional tem me proporcionado inúmeros momentos de inquietação e reflexão acerca da realidade dos processos educacionais e escolares em nosso país. Desde adolescente, por conta da minha formação pessoal e escolar, me preocupava com as questões sociais que percebia em meu entorno. De família católica, com uma formação voltada para olhar os outros, perceber seus problemas e buscar superações pautadas em justiça, em solidariedade, em amor ao próximo, os problemas vivenciados no Brasil quanto à pobreza, violência, desigualdade sempre me incomodaram muito. Quando fui cursar o colegial, na década de 80 - ensino médio da época - entrei num colégio progressista, fundado por militantes políticos, que enxergavam a educação como umas das possibilidades de transformação social. Com 15 anos, já lia Paulo Freire e me encantava com os caminhos que percebia serem possíveis - de maior igualdade social - se formássemos as pessoas, se elas tivessem chance de ter mais dignidade em suas vidas cotidianas.

Estas considerações iniciais se fazem necessárias para que se organize um quadro dos meus primeiros referenciais teórico-práticos. Ideias progressistas, de libertação da opressão somadas a uma vontade e uma crença ser possível transformar o mundo - crença que alias, tenho presente comigo fortemente até hoje!

Na década de 80, mais precisamente em 1984, comecei a cursar Pedagogia na Unicamp e logo no meu primeiro ano de faculdade ingressei num grupo de pesquisa, com um trabalho de iniciação cientifica. Tenho, portanto, uma trajetória de construção como pesquisadora, desde meus primeiros momentos na formação como docente. Identifico que um dos pontos que me construiu como a profissional que sou hoje, foi 
justamente esse mergulhar em processos de reflexão e produção de conhecimento desde o início da minha trajetória de formação.

Logo após me formar, em 1987, iniciei meus trabalhos em cursos de formação inicial de professores. Nesses anos de atividade profissional, tenho procurado pesquisar para compreender melhor como os jovens em formação vêem o mundo, como percebem sua atuação em sociedade. Tenho buscado compreender como a escola e os professores formadores podem colaborar para que os futuros formadores sejam profissionais atuantes na sociedade, sejam profissionais comprometidos com as questões sociais cruciais, que consigam analisar e buscar caminhos de transformação para os problemas percebidos.

Minhas inquietações quanto à educação, comunicação e as mídias, em especial a $\mathrm{TV}$, tiveram início quando comecei a perceber no cotidiano social, inclusive no cotidiano das escolas, como as crianças e os adolescentes reproduziam discursos televisuais, como incorporavam maneiras de se vestir e de se comportar apresentadas por personagens dos programas de $\mathrm{TV}$, principalmente personagens de desenhos animados e de telenovelas. Minha inquietação tornou-se maior quando parei para analisar alguns desses programas, que tinham audiência alta, e vi alguns dos significados que eram construídos nesses programas, tais como competição, violência de todos os níveis, valores como traição, fofoca, intolerância. Comecei a me perguntar o que fazíamos enquanto professores diante dessa realidade.

Coincidentemente, no mesmo período em que essas reflexões sobre o cotidiano e sobre meu trabalho como formadora me inquietavam, numa das escolas de ensino médio em que lecionava, no ano de 1989, houve uma semana de palestras para formação contínua dos professores. Uma delas enfatizou a importância dos meios de comunicação na sociedade atual, questionando a chamada realidade virtual. $O$ palestrante, na ocasião, abordou temas como pós modernidade e função da escola na era do desenvolvimento rápido e acelerado das tecnologias. Somada aos meus questionamentos, aquela palestra motivou-me a querer pesquisar um assunto inquietante para mim: como seria a relação professor-aluno num mundo altamente tecnologizado? A evolução das técnicas, da velocidade da informação, da facilidade de acesso a essa informação determinariam a extinção da escola? Os alunos "liam" o mundo mediatizados pela televisão? Como isso influenciava sua formação? Qual o papel da escola e dos professores nessa mediatização? 
Foi com estes questionamentos que iniciei meus estudos para o mestrado $^{1}$ na Faculdade de Educação da USP, na área de Didática, Teorias de Ensino e Práticas Escolares.

\section{Como nos coloca Boff:}

A cabeça pensa a partir de onde os pés pisam. Para compreender, é essencial conhecer o lugar social de quem olha. Vale dizer: como alguém vive, com quem convive, que experiências tem, em que trabalha, que desejos alimenta, como assume os dramas da vida e da morte e que esperanças o animam. (BOFF, 1997:9)

Expressei, com estas breves considerações iniciais, meu lugar social, as experiências que por primeiro me motivaram a pesquisar e buscar a construção de outros caminhos para a relação entre educação, escola e sociedade. Em minha trajetória, tanto profissional como pessoal, a compreensão de que as transformações sociais necessárias também passavam pela educação, pelos muros das escolas, foi essencial. A educação pode ser um dos caminhos de mudança, ao assumirmos em nossas tarefas cotidianas docentes, a reflexão, o desenvolvimento da percepção crítica da realidade que nos cerca, a construção de alternativas viáveis aos problemas sociais. Como nos diz Libâneo:

Não dizemos mais que a escola é a mola das transformações sociais. Não é, sozinha. As tarefas de construção de uma democracia econômica e política pertencem a várias esferas de atuação da sociedade, e a escola é apenas uma delas (...) tem, também, o compromisso de ajudar os alunos a tornarem-se sujeitos pensantes, capazes de construir elementos categoriais de compreensão e apropriação crítica da realidade. (LIBÂNEO, 1998:10)

Essa compreensão do papel social da educação e da escola somada a minha trajetória de trabalho em cursos de formação, me fazem entender a formação de professores como uma das prioridades da educação brasileira. Enxergo a formação de um professor como possibilidade de transformação, de formação de pessoas capazes de processos de reflexão sobre as questões sociais, capazes de articular saberes e fazeres na busca de novas perspectivas. No mesmo sentido que venho construindo desde meu mestrado, acredito que formando professores preparados para debruçar-se sobre as questões do mundo em que vivem, das sociedades nas quais estão inseridos, podemos

\footnotetext{
${ }^{1}$ Mestrado realizado na FEUSP, sob orientação da Profa. Dra. Maria Felisminda de Rezende e Fusari, entre 1995 e 1998, com o seguinte título na dissertação: "Televisão e formação inicial de docentes: a importância da mediação docente.”
} 
elaborar propostas pedagógicas, projetos educacionais e escolares que favoreçam a construção do conhecimento emancipatório e de uma cidadania efetiva, entendida como possibilidades de participação social, buscando alternativas para as situações vivenciadas cotidianamente, com vistas a qualidade de vida para todos.

Em meus estudos anteriores, no mestrado, trabalhei o cruzamento de duas áreas que me inquietavam: a formação de professores e as questões comunicacionais, em especial as ligadas à TV e aos jovens.

Quanto à formação de professores, um dos referenciais utilizados no mestrado foi POPEKWITZ (1996) e sua argumentação de que os modelos de formação do professorado, existentes nos diversos países, são elementos centrais no nexo de poder e conhecimento, tanto na educação como na sociedade. A formação de professores pode desvelar as formas pelas quais os governos mantêm seus sistemas econômicos e políticos, controlando a preparação dos docentes, os currículos, enfim, o conhecimento que se produz e suas implicações sociais. Ao entendermos a formação de professores tanto inicial quanto contínua - como ponto fulcral, o estudo das questões educacionais e escolares necessitam de amplitude, considerando as implicações econômicas, políticas e culturais, considerando-se a formação de professores como constituidora e constituída pelas sociedades nas quais o processo de formação está acontecendo. Ou seja, hoje falamos de uma formação de professores que acontece em sociedades midiáticas, onde as produções simbólicas colaboram na constituição dos sujeitos e, portanto na construção do tecido social, exigindo que estes professores dialoguem e sejam mediadores diante destas novas linguagens.

Ao estudar a formação inicial de professores em sua relação com a TV, dando destaque para o papel da mediação docente, procurei nas leituras do mestrado compreender as interfaces entre educação e comunicação, considerando as duas áreas como produtoras de cultura e participantes dos processos de construção de identidade dos sujeitos nas sociedades midiáticas contemporâneas.

Como nos coloca PAULO FREIRE (1994), entre educador e educando deve existir uma relação dialógica, que estabeleça conversas entre o mundo de ambos, articulando os diversos saberes e experiências, as diversas leituras de mundo. Diante das novas tecnologias e dos impactos que trazem para as relações humanas de forma geral e também para a área educacional, as funções da escola e dos professores precisam ser revistas, analisando-as à luz do que vivenciamos hoje, do que a sociedade atual nos 
apresenta, do como estamos nos construindo enquanto pessoas. Leda Scheibe traz uma contribuição para esta reflexão:

Há hoje uma distância enorme entre as experiências proporcionadas pela escola e as características culturais que se transformam pela dinâmica do social. A educação institucionalizada continua a basear-se ainda fortemente em parâmetros de um mundo social que não mais predomina. (SCHEIBE, 1995:169)

Nos estudos de mestrado já apontei a minha preocupação quanto às formas dos professores trabalharem com as questões comunicacionais midiáticas. Ao entendermos que é preciso conhecer e partir da realidade dos alunos para efetuar nosso trabalho pedagógico, fica evidente que a escola precisa estabelecer canais de diálogo com as mídias, pois estas fazem parte do cotidiano dos alunos, apresentando em sua grade de programação, sentidos e significados diante do mundo que colaboram para a construção de ideias e posicionamentos que estes mesmos alunos têm diante da sociedade na qual estão inseridos.

Tivemos, quanto ao mestrado, o intuito de investigar a relação entre adolescentes e televisão e quais as mediações, nessa relação, dos professores desses alunos, sobretudo em se tratando da formação desses jovens, como professores, também mediadores da educação de outros alunos. Buscamos também alternativas para uma formação comunicacional de professores, com mídias, que estivesse mais atenta às realidades da sociedade atual. Para os estudos sobre mediação docente e sobre as formas de recepção comunicacional efetivadas por adolescentes trabalhamos com REZENDE E FUSARI (1990), ROCCO (1990), MARTÍN-BARBERO (1995), FISHER (1982), entre outros.

Como eixos principais da análise, trabalhamos na perspectiva de formar professores com habilidades específicas para mediação entre adolescentes e crianças e a programação da TV, colaborando na formação de leitores críticos e produtores de comunicação social; propusemos a mediação docente como um caminho capaz de incorporar a linguagem das mídias - tais como a televisual- ao cotidiano escolar e aos cursos de formação de professores, na perspectiva de cursos mais articulados a realidade social contemporânea.

Em meu percurso profissional, como professora universitária, comecei a trabalhar, alem dos cursos de formação de professores, em cursos da área de comunicação social, tais como curso de Rádio e TV, Propaganda e Marketing, Jornalismo. Se já havia uma 
preocupação em meus estudos iniciais quanto às questões da interface entre a área de comunicação e a área de educação, atuar como professora junto a estudantes de comunicação e trabalhar em conjunto com profissionais dessa área, fez com que meus questionamentos e inquietações aumentassem. Fez-me perceber um hiato existente no dialogo entre as duas áreas, hiato que percebo inclusive na Universidade em que curso hoje o doutorado. Em muitos momentos, percebo que educadores e comunicadores tem dificuldades em estabelecer um diálogo entre as duas áreas, em encontrar pontos comuns que possam fazer o diálogo avançar, na direção de colaborar para a construção de uma sociedade mais igualitária, atravessada hoje pela produção de uma cultura simbólica que exige reflexões cuidadosas tanto da parte dos educadores como da parte dos comunicadores sociais.

Estas inquietações e percepções me levaram a escrever o projeto de doutorado ${ }^{2}$, buscando construir um diálogo mais efetivo entre a educação e a comunicação, principalmente no que tange a formação inicial de professores em sociedades midiáticas, sociedades estas onde as crianças e adolescentes estão aprendendo de formas diferenciadas, exigindo, portanto, que a formação de professores também aconteça de novas formas.

É nessa interface entre a área de educação e a área de comunicação que nasce esse projeto de doutorado.

A preocupação desta pesquisa é com a formação inicial de professores em sua relação com a sociedade midiática atual. Esta relação parece exigir dos professores em atuação nas escolas um preparo diferente para lidar com alunos nascidos e criados nesta sociedade midiática, em função das demandas atuais de avanços tecnológicos, inclusive comunicacionais, que impactam a produção cultural. Pesquisas (Orozco, 2009; Citelli, 2004; Prensky, 2006) indicam que as formas de relacionar-se e aprender dos alunos transformaram-se. Tem a atenção difusa, apresentam soluções rápidas para os problemas, tem multifocalização, sendo capazes de estar atentos em objetos diferentes, com focos diversos. Alunos que aprendem dessas formas diferenciadas, exigem dos professores habilidades comunicativas capazes de lidar com múltiplas linguagens, em suportes diferenciados, numa configuração social perpassada por tecnologias comunicacionais, que geram um ecossistema educomunicativo, onde comunicação e educação são áreas que se interpenetram, inclusive na constituição da identidade dos

\footnotetext{
${ }^{2}$ Iniciei meus estudos para o doutoramento em março de 2009, na FEUSP.
} 
indivíduos, nas formas com as quais estes indivíduos aprendem, se socializam e partilham significados diante do mundo em que vivem.

Para contextualizar nossa preocupação quanto aos estudos propostos é preciso refletir brevemente sobre as mudanças que vem ocorrendo em nossas sociedades ao longo dos últimos anos do século XX e inicio do século XXI. Quais modificações percebemos na cultura e na sociedade e como estas mudanças impactam as formas de relacionamento entre as pessoas, as formas de ser e estar, impactando também as formas de ensinar e aprender? Qual a nova configuração social que estamos vivenciando?

Nas palavras de Bauman, vivemos uma vida líquida, "uma vida precária, vivida em condições de incerteza constante" (BAUMAN, 2007: 8)

A vida líquida é uma forma de vida que tende a ser levada à frente numa sociedade líquido-moderna. Líquido-moderna é uma sociedade em que as condições sob as quais agem seus membros mudam num tempo mais curto do que aquele necessário para a consolidação, em hábitos e rotinas, das formas de agir. A liquidez da vida e a da sociedade se alimentam e se revigoram mutuamente. (BAUMAN, 2007: 7)

Esta metáfora da liquidez da vida nos remete a uma ideia do líquido escorrendo pelas nossas mãos. Não temos como contê-lo, ele escorre e vai para os mais diversos pontos. Não sabemos nem como conter o líquido, nem em quais locais ele vai escorrer... Uma vida que nos escapa, nos assusta, pela própria fluidez! Vivemos em tempos de incerteza constante, de transformações cada dia mais aceleradas e intensas. Uma parte considerável destas transformações está ligada aos avanços tecnológicos dos últimos anos. Até meados do século XX, não tínhamos vários artefatos culturais que fazem parte do nosso cotidiano atual, como TV, internet, aparelhos de telefonia móvel, e-books, Ipods, tablets. O avanço da industrialização e os investimentos dos países considerados mais desenvolvidos em tecnologia, em informática, em robótica, trouxeram transformações cotidianas e novas possibilidades sociais e culturais. Os avanços e criações na área da tecnologia comunicacional, com novos meios de comunicação, possibilitou a divulgação de informações num nível global, de maneira padronizada. A revolução tecnológica comunicacional amplia, cada vez mais, a capacidade de produção, acumulação e veiculação de dados e informações. As novas possibilidades também trazem novos desafios e problemas. Ao mesmo tempo em que assistimos a avanços dos conhecimentos, das ciências e das tecnologias de comunicação e informação, também vemos uma situação paradoxal: aumento das disparidades sociais, 
acirramento das guerras por questões locais e disputas de territórios, globalização não só tecnológica, mas também da miséria e das péssimas condições de vida. Enquanto uma parte da humanidade desfruta dos avanços tecnológicos, ainda temos outra parcela considerável que não tem condições básicas de moradia, saúde e educação.

Os novos aparatos tecnológicos comunicacionais mudaram nossos contatos humanos. Autores como OROZCO (2009) nos falam de uma comunicação e contato via diferentes telas, que permitem, entre outras coisas, portabilidade e deslocamento, como é o caso da tela dos celulares, da tela dos computadores pessoais, como é o caso da programação dos canais de TV em telas de celulares. Comunicamo-nos hoje, de forma rápida, em qualquer lugar em que estejamos. Não precisamos mais nos comunicar somente por contato direto: acordo, ligo o laptop, me conecto à rede mundial de computadores - a internet - e em segundos, tenho acesso a diversas fontes de informação, jornais do mundo inteiro, revistas, blogs. Com um toque no celular, me comunico com pessoas em outras localidades, de forma rápida. Tenho acesso a amigos e conhecidos, nas chamadas redes sociais, tais como Orkut, Facebook, Twiter. Posso postar minhas atividades diárias e saber das atividades de todos nas páginas dessas redes sociais. Há uma velocidade na circulação das informações que não tínhamos em anos passados. Além da velocidade, há um enorme acesso as mais variadas informações, com linguagens diversas. Posso escutar música, fazer um tour virtual num museu europeu sem sair da cadeira da minha sala.

Estas possibilidades, criadas em função dos avanços tecnológicos, mudaram as nossas formas de comunicação, impactaram nossas produções culturais. Não são somente transformações tecnológicas e nos aparatos de comunicação, são mudanças na produção cultural de nossas sociedades, mudanças na própria forma de produção e circulação da comunicação.

Como nos diz Martín-Barbero:

Quando dizemos tecnologia, o que estamos nomeando, não é somente uma coisa, mas um âmbito extremamente potente, tanto de linguagens como de ações, tanto de dinâmicas sociais, políticas e culturais, quanto de interrogações sobre o que significa o social hoje. (MARTÍN-BARBERO, 2009:148)

As mudanças acontecem, portanto, não só no campo da tecnologia, mas nas dinâmicas sociais, trazendo uma nova configuração social, novas formas de agirmos, sentirmos, pensarmos e nos relacionarmos em sociedade. Estas mudanças perpassam as 
diversas instituições sociais, entre elas a escola, como um local por excelência de trabalho com conhecimentos e informações por meio de relacionamentos humanos. A escola, enquanto representação social, sempre esteve vinculada a ideia de local para transmissão de conhecimentos para as novas gerações, de espaço de socialização dessas mesmas gerações. Íamos à escola para aprender sobre nossas sociedades, aprender hábitos e valores, formas de comportamento. Socializávamo-nos na escola, com nossos colegas e professores, adquiríamos hábitos e atitudes.

Obviamente, isso tudo ainda acontece em nossas escolas, mas temos hoje a emergência de outros espaços de socialização. Além de aprendermos hábitos e atitudes em nossas escolas, a programação da TV, por meio de telenovelas, desenhos animados, telejornais, programas de auditório, nos oferece uma ampla gama de sentidos e significados. Os inúmeros sites a que temos acesso via Internet nos trazem não somente informações, mas jeitos de ver e estar no mundo. Um site bastante visitado por meninas em idade escolar, é o site da Barbie, boneca criada pela empresa estadunidense Mattel. Nesse site você pode navegar pelo quarto da Barbie, que apresenta TV de LCD, aparelho celular, todo decorado em rosa. Você pode também vestir um entre os inúmeros modelitos apresentados no guarda roupa da boneca, com inúmeras bolsas, sapatos e casacos. Será incentivado a ser fashion, estar na moda, com looks variados. O que será que podem aprender meninas, que talvez estejam estudando em escolas de bairros periféricos, sem acesso a rede de esgoto, ao entrarem num mundo de representações virtuais, com construção de sentidos sobre o que é ser mulher, sobre o que é ser feliz?

As provocações acima são para pontuar que em sociedades midiáticas como é a nossa, as crianças tem acesso a informações, a hábitos e atitudes também por meio das inúmeras mídias com as quais convivem todos os dias. A escola é somente um dos locais de socialização e aprendizagem de costumes e valores.

É nesse sentido que alguns autores, como MARTÍN-BARBERO (2009), constroem a noção de ecossistema comunicativo, ao falarem de uma nova ambiência cultural, com um conjunto de linguagens, de formas de escrita, de representações que transformam as formas de percepção e relação entre as pessoas.

Ao trabalharmos na interface entre duas áreas do conhecimento consolidadas, como são as áreas de educação e comunicação, temos que explicitar algumas escolhas teórico conceituais. Ao percebermos um hiato no diálogo entre as duas áreas, buscamos 
uma construção que permita a aproximação entre essas áreas, para podermos discutir o ponto que nos interessa: o trabalho com educação em sociedades midiáticas, com produções culturais simbólicas, onde as crianças aprendem de outras formas exigindo um repensar da formação de professores.

Não há mais como não articular educação e comunicação, pois as duas áreas são estratégicas para as sociedades atuais, no sentido de trabalharem, em seu conjunto de análises e reflexões, em suas atividades sociais, com produção de cultura e, nesse processo, com a constituição da identidade dos indivíduos.

Neste trabalho assumimos a busca de uma proposta de diálogo, que favoreça a troca de experiências entre a área da comunicação social e a área da educação, que favoreça a articulação de constructos teóricos das duas áreas na construção de uma nova área de conhecimento, a educomunicação.

Partimos da premissa de que a educomunicação, conceito que designa um campo de ação emergente na interface entre os tradicionais campos da educação e da comunicação, apresentase, hoje, como um excelente caminho de renovação das práticas sociais que objetivam ampliar as condições de expressão de todos os seguimentos humanos, especialmente da infância e da juventude. (SOARES, 2011: 15)

Assim, trabalhar na perspectiva da educomunicação é trabalhar com a noção de ampliar e analisar possibilidades de comunicação, de expressão de ideias e anseios, no sentido de ampliar a participação em nossas sociedades, de forma inclusiva e democrática, onde não só os grandes conglomerados comunicacionais apresentem suas visões de mundo utilizando as diversas mídias existentes, mas que qualquer pessoa consiga não só analisar criticamente as propostas veiculadas pelas mídias, mas empoderar-se e perceber-se como produtora social de comunicação, utilizando as novas possibilidades tecnológicas que existem para construção de uma cultura mais participativa, pautada em respeito às diversidades e promotora do diálogo entre todas as pessoas. Em especial, apontamos a necessidade de assumirmos a educomunicação como um dos eixos dos cursos de formação inicial de professores, preparando os atuais educandos e futuros docentes para um trabalho articulado entre educação e comunicação, que favoreça a promoção de diálogos críticos entre o trabalho mais propriamente didático e pedagógico e os desafios que nos trazem as transformações tecnológicas e culturais das sociedades contemporâneas. 
As crianças que estão em nossas escolas hoje são nascidas e criadas dentro desse contexto de transformações sociais aceleradas, relacionando-se com o mundo de formas diferentes das que nos relacionávamos antes. PRENSKY (2006) usa o termo nativos digitais ao referir-se a essas crianças: nascem em meio a tecnologia, utilizam os mais diversos aparelhos, muitas vezes simultaneamente, processam informações de forma cada vez mais rápida, com um raciocínio que não é linear, mas pautado em múltiplas conexões. Nas palavras de Ignácio, "crianças e jovens interagem na contemporaneidade em um mundo 'teleguiado', em constante mutação e repleto de informações." (IGNÁCIO, 2009:47)

Segundo COSTA (2009), imbricado nestas informações, está a prática de um consumo cada vez mais voraz, que está relacionado a formas de pertencimento social. Crianças e jovens, em nossas sociedades contemporâneas, aprendem, inclusive via propagandas veiculadas nas diversas mídias, a serem aceitas socialmente pelo consumo. A programação exibida nas telas da TV, as informações nos diversos sites das telas dos computadores, nos trazem sempre novidades a serem consumidas, novidades estas que estão relacionadas a formas de ser e estar no mundo. Falamos de um trabalho a ser desenvolvido em nossas escolas, com crianças que não aprendem somente informações num contexto perpassado por novas mídias. Aprendem também formas de conviver, formas de olhar e sentir a si mesmas e aos outros, aprendem sentidos sobre a vida nos inúmeros programas e sites com os quais interagem cotidianamente.

Ao pensarmos as questões educacionais e escolares hoje, fundamental pensar em como educar crianças que vivem em sociedades midiáticas, que interagem todos os dias com múltiplas linguagens, em suportes diferenciados e convergentes entre si, que trazem infinitas possibilidades de criação e recriação, possibilidades de experimentação. Pensar em como educar crianças que desenvolvem o raciocínio de forma cada vez mais acelerada, mas nem sempre acompanhada da profundidade e reflexão necessárias, com elaboração e síntese das informações as quais tem acesso.

Pensar em como sermos mediadores, enquanto professores/comunicadores educomunicadores - das inúmeras informações as quais as crianças e jovens tem acesso, colaborando na reconstrução de significados, que contribuam para uma convivência mais solidária e cidadã em nossas sociedades. Em como sermos professores que colaborem no desenvolvimento de posturas crítico-reflexivas, a favor de uma sociedade mais igualitária e inclusiva. 
FISHER (2006) fala da TV como prática social, discorrendo sobre a importância de entendermos que quando consumimos imagens, notícias, quando nos entretemos com os programas, estamos vivenciando práticas que estão relacionadas à produção de sentidos sobre nossa vida em sociedade. Diante deste entendimento, os educadores devem trabalhar as mídias com os alunos, assumindo esse trabalho enquanto tarefa educativa:

\begin{abstract}
Apropriar-se desse meio, estudar suas estratégias de endereçamento, de criação de imagens e sons, compreender a complexa trama de significações que aí estão em jogo - acredito que seja uma tarefa eminentemente educativa, pedagógica, no melhor sentido desse termo. (FISHER, 2006: 51)
\end{abstract}

Ao trabalhar com a rede de significações que estão presentes nos diversos programas da TV ou nos inúmeros sites navegados pelos alunos, o professor atua como mediador, interpelando os alunos quanto aos significados propostos, possibilitando a releitura, a resignificação. Possibilitando a recriação do que está veiculado nas mídias, pela leitura crítica dos alunos e pela capacidade de produção de outros sentidos, que colaborem para uma qualidade de vida para todos.

Ao entendermos o lugar que as mídias, como TV e computador, ocupam hoje em nossas sociedades, como instância de socialização, de divulgação de valores, hábitos e atitudes, de fonte de informação, de entretenimento, principalmente para as novas gerações, nascidas e criadas em sociedades midiáticas, torna-se evidente o papel da escola e dos professores como mediadores, como articuladores entre as varias ideias, informações e significados que circulam numa sociedade dividida em classes como a nossa.

A preocupação com um olhar mais crítico e atento sobre a produção midiática e como ela é recebida e elaborada não deve estar restrita somente aos alunos. Neste trabalho, enfatizamos a preocupação com a formação de professores que serão formadores de alunos, principalmente nas escolas públicas. É uma rede de mediações contínuas, em que se propõe um trabalho em todo o tecido social, pois as relações pessoais se interpenetram, nos mais diversos espaços e tempos. Um trabalho sobre mídias e com mídias, tendo como um dos eixos a mediação docente, é essencial hoje em cursos de formação de professores, para garantir um espaço e tempo de formação que seja espaço de troca, de interação, de negociação de sentidos. Ao construirmos e articularmos espaços e tempos que nos permitam debater as questões relacionadas à 
nossa vida em sociedade, em como percebemos o mundo e as pessoas que convivem conosco, espaços que nos permitam refletir sobre nossas próprias concepções e percepções, construímos também alternativas para nossa sociedade. CANCLINI (1995) afirma que precisamos reconquistar criativamente os espaços públicos, o nosso interesse pelo público, para redirecionarmos entre outras questões, a do consumo, inclusive de bens simbólicos. Trazer as mídias para o centro do debate em nossas escolas e cursos de formação de professores, mediando a leitura que as crianças e adolescentes fazem dos produtos midiáticos, é caminhar nessa direção da reconquista do espaço que é de todos, que é por isso mesmo, público! Pensar uma escola que exerça mediações para a leitura crítica e para uma produção social da comunicação com vistas à qualidade de vida para todos.

Para que esse exercício da mediação docente ocorra em nossas escolas, há que ter um olhar voltado para a formação inicial de professores, como ela vem acontecendo ao longo dos últimos anos e como pode ser pensada em função de novas demandas sociais e culturais. Pensar uma formação de professores que esteja articulada, entre outras questões, às discussões sobre a comunicação e sua interface com processos educacionais e escolares.

Autores como ESTEVE (1995) e NÓVOA (1995) nos apresentam uma mudança de cenário social e como esta mudança incide sobre os processos de formação de professores.

Essa também é a perspectiva que nos traz Orozco:

Neste novo século, a educação cada vez mais estará vinculada aos meios e tecnologias de informação e que, cedo ou tarde, isto vai modificar de maneira substancial os processos educativos e comunicativos. O cenário do futuro não é estático, muito pelo contrário. Por isso é importante antecipar o papel que tanto educadores quanto comunicadores devemos tomar, para que o sentido e a direção das inevitáveis transformações sejam as mais relevantes para nossas sociedades. (OROZCO, 2011: 173)

Pensar como trabalhar em nossos cursos de formação inicial de professores, em especial os cursos de Pedagogia, este cenário de mudanças, que nos trazem interfaces entre a educação e comunicação, é pensar qual sociedade temos e qual sociedade precisamos e queremos construir, como queremos pensar uma educação que seja cada vez mais inclusiva, pautada em respeito à diversidade, ao diálogo, a solidariedade.

GATTI e BARRETO (2009) nos apontam, em estudo realizado sobre os professores no Brasil, que é necessária uma revolução nas estruturas institucionais 
formativas e nos currículos de formação, destacando que há uma fragmentação nos processos de formação e que é preciso rever a direção e pensar a formação de professores articulada a função social da escola: "ensinar às novas gerações o conhecimento acumulado e consolidar valores e práticas coerentes com a nossa vida civil.” (GATTI e BARRETO, 2009: 257)

Gatti e Barreto ainda destacam a importância de partir de um campo da prática e agregar conhecimentos necessários que sejam considerados importantes e fundamentais para o exercício docente, para as mediações didáticas necessárias, enfatizando que se deve considerar um trabalho a ser realizado com crianças e adolescentes. Neste sentido, Gatti e Barreto se aproximam da discussão que estamos propondo neste trabalho, qual seja, uma formação de professores que considere as práticas e vivências sociais de todos, não só dos alunos que serão formados, mas também dos alunos em processo de formação para que sejam, no futuro, formadores. Todos pertencentes a um campo cultural perpassado por mídias e por diversas produções simbólicas, onde é necessário aprender a dialogar com essa produção, aprender a analisá-la, refleti-la, para, apropriando-se dela, recriá-la em prol de uma comunicação mais democrática e inclusiva. Formar o professor como um intelectual crítico, que conhece e vive a cultura de seu tempo, conseguindo analisá-la, pensá-la, transformá-la quando necessário, buscando qualidade de vida para todos.

CITELLI (2011) também aponta um descompasso entre as demandas que temos hoje, em sociedades midiáticas, e a formação de professores.

É como se estivéssemos diante de duas realidades distintas: uma representada pelos envolvimentos sociais com os sistemas e processos de comunicação e outra adstrita a determinados marcos institucionais que balizam e circunscrevem o mundo da escola. (CITELLI, 2011: 73)

Esta é uma inquietação central neste trabalho: a necessidade de estabelecer e aprofundar um diálogo entre as áreas de comunicação e educação, no que tange a um trabalho nas escolas e nos cursos de formação inicial de professores, de aproximação das dimensões didáticas aos desafios trazidos pelas sociedades midiáticas contemporâneas. Preocupação que estamos estudando desde o mestrado e que propomos um aprofundamento dos estudos no doutorado.

Assim, se configura como preocupação central desta pesquisa a formação inicial de professores em sua relação com a sociedade midiática atual, que exige desses 
profissionais em atuação nas escolas um preparo diferente para lidar com alunos nascidos e criados em meio a transformações tecnológicas e culturais, que aprendem de formas diferenciadas, exigindo dos professores habilidades comunicativas para lidar com múltiplas linguagens, numa nova configuração social, perpassada por tecnologias comunicacionais, que geram um ecossistema ${ }^{3}$ educomunicativo, onde comunicação e educação são áreas que se interpenetram, inclusive na constituição da identidade dos indivíduos, nas formas com as quais estes indivíduos aprendem, se socializam e partilham significados diante do mundo em que vivem.

Buscamos identificar aspectos da formação docente que possam ser trabalhados na perspectiva de uma formação mais articulada com uma sociedade que passa por transformações cada vez mais aceleradas, inclusive no que tange à questões comunicacionais, interpelando os cotidianos sociais, inclusive os cotidianos escolares e os processos de ensino aprendizagem.

Assim, temos como questão central do trabalho:

Como os cursos de formação inicial de professores estão trabalhando em seus quadros curriculares, com as mudanças culturais e comunicacionais da contemporaneidade, para que os futuros professores estejam preparados para lidar com alunos que aprendem de formas diferentes e vivenciam aprendizagens perpassadas por questões midiático-comunicacionais?

Diante desta questão e da problemática apresentada, temos alguns pressupostos, sempre considerando essas hipóteses numa perspectiva de pesquisa qualitativa, na área de educação, ou seja, não trabalhamos para confirmá-las ou refutá-las, mas pensamo-las como formas de balizar a reflexão no processo de desenvolvimento da pesquisa em curso.

Acreditamos que, via de regra, os professores não são preparados em seu período de formação inicial, nos cursos de Pedagogia, para o trabalho numa sociedade tecnológica midiática, onde a comunicação assume uma posição cada vez mais estratégica como cerne cultural e por isso mesmo, interfere nos cotidianos escolares, nos processos de ensino e aprendizagem, nas formas que temos acesso a informação e a elaboramos/reelaboramos.

\footnotetext{
${ }^{3}$ Adotamos aqui o conceito de ecossistemas comunicativos do Núcleo de Comunicação e Educação da ECA/USP, compreendidos como sistemas complexos, dinâmicos e abertos, conformados como espaço de convivência e de ação comunicativa integrada. (SOARES, 2011).
} 
Articulada a este pressuposto, também trabalhamos com a ideia que os professores continuam sendo preparados para uma sociedade que não existe mais, baseada somente em códigos escritos e no domínio dos processos de leitura e escrita em suportes impressos.

Os alunos atuais - sujeitos das escolas de ensino fundamental - nascidos e criados numa sociedade tecnológica, são portadores, também em função das novas mídias, de novas formas de ver e estar no mundo. Desenvolveram novas formas de aprendizagem, que exigem outra atuação dos professores, que necessitam de outro tipo de formação que os prepare para questões educomunicacionais e aptos a trabalhar com uma geração de alunos que aprende de formas diferenciadas, com novas linguagens, em novos suportes.

Diante destas considerações, temos como objetivo central desta pesquisa:

Propor uma formação inicial de professores que, em função das novas demandas sociais e culturais, especialmente no que tange a aspectos comunicacionais midiáticos, prepare os professores polivalentes para mediar novas formas de aprendizagem de alunos inseridos em sociedades com uma cultura perpassada pela tecnologia e suas novas linguagens.

Temos como objetivos complementares:

1. Analisar como se desenvolve a formação de professores na interface com as questões comunicacionais midiáticas, com enfoque particularizado nos seis cursos de Pedagogia da cidade de Santos, Estado de São Paulo, tendo como referência as matrizes curriculares das faculdades e universidades da cidade.

2. Analisar como professores do Ensino Fundamental I de oito escolas da Rede Pública Municipal de Santos expressam a compreensão que tem a respeito de suas práticas pedagógicas, em especial no que tange ao trabalho com novas mídias em suas aulas.

3. Apontar possíveis relações entre o que está previsto para o período de formação inicial dos professores, à luz das Diretrizes Curriculares Nacionais, com o que eles dizem a respeito do seu trabalho nas escolas, avaliando se a formação inicial tem contribuído para o desenvolvimento de práticas pedagógicas articuladas com os desafios das sociedades contemporâneas, tecnologizadas e midiáticas. 
4. Apontar novas possibilidades para a formação inicial de docentes num contexto educomunicativo.

Em seguida, explicitamos o caminho da pesquisa, por onde andamos para chegar a algumas considerações sobre a formação de professores em sociedades midiáticas.

\section{O caminho da pesquisa: múltiplos lugares, tempos e olhares}

Pesquisar é um ato de debruçar-se sobre o que percebemos e entendemos como as realidades, sobre os sujeitos que estão inseridos nestas realidades, construindo e sendo construídos por elas. É também um ato de debruçar-se sobre si mesmo, sobre sua própria trajetória acadêmica e profissional. Refletir sobre os próprios pressupostos diante da vida, diante das relações com outros seres humanos.

Por isso mesmo exige coragem, a coragem de remexer em ideias, conceitos, em representações sociais construídas ao longo dos anos, com as muitas experiências vivenciadas. É ainda um momento de solidão, em que é preciso recolher-se um pouco, sentir, ler muito, refletir mais um tanto e produzir. Produzir ideias, conceitos, formas de ver as pessoas e os acontecimentos. Mas como tudo tem dois lados, é um momento de criação coletiva. Cada autor lido é parceiro na jornada, ajuda a enxergar a situação por outro prisma, que ainda não tinha sido visto. Cada reflexão em conjunto com o orientador, propõe uma nova faceta do assunto em questão.

Pesquisar é sempre um trabalho de criação, de assumir correr riscos, de buscar respostas para perguntas que às vezes ainda não se tem clareza.

Pensando nestas questões, tomo como referencial epistemológico desta pesquisa o dialético crítico, numa compreensão de permanente movimento e transformação das sociedades e dos seres humanos. (LOPES, 2001)

Ao fazermos pesquisa, nos transformamos enquanto pesquisadores, transformamos os lugares e tempos onde debruçamos nosso olhar, provocando outros movimentos e leituras diante da realidade, transformamos uns aos outros nos encontros e desencontros causados pelas reflexões e análises.

Ainda pode ser considerado dialético crítico ao buscar um trabalho na articulação de duas áreas - educação e comunicação - e todos os aspectos que as 
permeiam, sociais, culturais, políticos, econômicos, assumindo uma busca de totalidade dos fenômenos e percebendo as contradições existentes.

Pesquisar, tendo como objeto de pesquisa, cursos de formação de professores e professores em atuação em escolas, que estão situados sócio e historicamente, mediados por tempos e espaços diversos, é considerar a dinamicidade das ações humanas em sua relação com a produção e vivência da cultura.

Ao trabalharmos com duas áreas do conhecimento, consolidadas em suas construções conceituais - como são a educação e a comunicação - é necessário um mergulho na complexidade que se estabelece na interface entre elas, buscando um diálogo, que assume os conflitos e partindo daí, busca novas sínteses conceituais.

Elaborando a pesquisa no entrecruzamento dos processos comunicacionais com os processos educacionais e escolares, destaca-se a compreensão de que tanto alunos como professores são agentes nos processos de comunicação. Como nos aponta Rezende E Fusari:

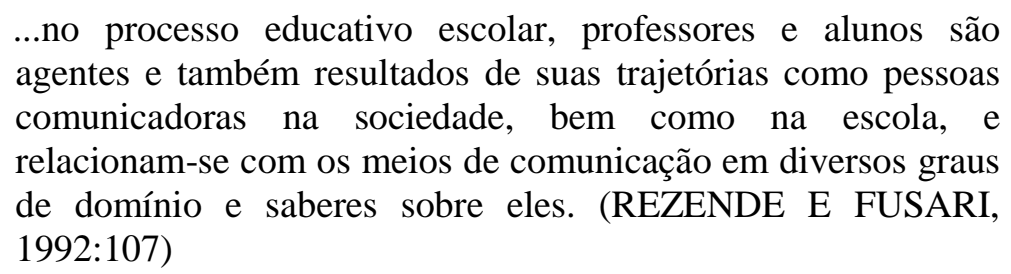

Pesquisamos a partir desta compreensão, para que possamos entender melhor as relações entre comunicação, em toda sua complexidade e como está articulada as escolas e cursos que temos hoje, com vistas a avançar em nossos estudos e propostas, na construção de uma escola que sonhamos e que necessitamos para uma sociedade mais justa em nosso país.

\section{A multirreferencialidade}

O próprio processo de pesquisa é uma busca de novos caminhos, que possibilitem investigar e criar formas de trabalhar com mídias, em toda sua complexidade comunicacional, em nossas escolas e, de forma mais especial, em cursos de formação inicial de professores.

Neste sentido, a abordagem deste trabalho também se baseia nas ideias de multirreferencialidade de Ardoino (1998), onde se buscam alternativas para a pesquisa diante da complexidade e pluralidade do mundo e das relações atuais: 
Assumindo plenamente a hipótese da complexidade, até mesmo da hipercomplexidade, da realidade a respeito da qual nos questionamos, a abordagem multirreferencial propõe-se a uma leitura plural de seus objetos (práticos ou teóricos), sob diferentes pontos de vista, que implicam tanto visões específicas, quanto linguagens apropriadas às descrições exigidas, em função de sistemas de referências distintos, considerados, reconhecidos explicitamente como não-redutíveis uns aos outros, ou seja, heterogêneos. (ARDOINO, 1998: 24)

Ardoino (1998), na abordagem multirreferencial, reconhece o caráter plural e complexo dos fenômenos sociais. Pondera que não é viável, diante da complexidade social, ter-se uma visão única da realidade. Reconhecendo o caráter complexo das práticas sociais e também das práticas educativas, onde não se pode falar em termos de homogeneidade, evidencia-se a necessidade de visões plurais e diferenciadas, para dar conta dos objetos de estudo.

A complexidade dos fenômenos educativos também é destacada por Franco:

A pesquisa em educação carrega diversas peculiaridades, pois trabalha com um objeto de estudo multidimensional, mutante, complexo, em que o caráter sócio-histórico de suas práticas faz com que cada situação educativa seja sempre única, irreptível, com imensas variações no tempo, no espaço, nas formas organizativas de sua dinâmica e no caráter de sua intencionalidade. (FRANCO, 2003:189)

Uma pesquisa na área de educação traz esta complexidade multidimensional, onde existe um objeto de estudo inicial e pressupostos que norteiam a pesquisa, mas também se assume uma construção metodológica que ocorre no próprio processo da pesquisa, diante das análises que vão sendo construídas.

Ao se relacionar, num processo de pesquisa, duas áreas do conhecimento, a complexidade é ainda maior. Neste sentido, a multirreferencialidade nos ajuda a ampliar o olhar, evitando reducionismos e permitindo ter a noção de uma multiplicidade de referências, que não se anulam entre si, mas que num processo fecundo de diálogo e interpenetração de ideias, colaboram para a análise das práticas sociais e educativas na complexidade ${ }^{4}$ das relações.

A abordagem multirreferencial parte da ideia de que os objetos de estudo podem ser interrogados de forma múltipla, não só pela multiplicidade de características existentes neles, bem como pela multiplicidade de olhares e questionamentos que se

\footnotetext{
${ }^{4}$ Complexidade é utilizada aqui no sentido da categoria de totalidade da teoria marxista, onde se busca superar uma concepção fragmentada e reducionista das realidades.
} 
pode ter sobre os mesmos, partindo de sujeitos também múltiplos, construídos a partir de diferentes referências de cada área do conhecimento, num entrecruzamento constante de concepções, ideias, representações, que não se esgota, ocorrendo em processos contínuos de reflexão e construção de possibilidades. Nas palavras de BUMHAM:

Uma das grandes contribuições que a perspectiva da multirreferencialidade pode trazer à escola é a abertura para se trabalhar com as linguagens, os valores, as crenças, enfim, uma multiplicidade de expressões das diversas culturas que se encontram nas escolas. (BUMHAM, 1993:8)

É esta possibilidade de trabalhar com uma multiplicidade de expressões, de diferentes e, por vezes, divergentes referências, que nos aproxima da abordagem epistemológica e metodológica proposta pela multirreferencialidade. Nas palavras do próprio Ardoino:

(...) quer dizer que no lugar de buscar um sistema explicativo unitário (...) as ciências humanas necessitam de explicações, ou olhares, ou de óticas, de perspectivas plurais para dar conta um pouco melhor, ou um pouco menos mal, da complexidade dos objetos. (ARDOINO, 1998:4)

Na perspectiva multirreferencial, parte-se da ideia de que o conhecimento sobre a educação, evidenciando-se a complexidade da mesma, se constrói por meio da articulação e da aproximação de diversas disciplinas, admitindo a dialeticidade das concepções e referências, onde o pensamento e o próprio conhecimento são gestados em contínuos movimentos. (Martins, 2004)

Neste mesmo sentido da multirreferencialidade, de entendimento da complexidade e multiplicidade das construções teóricas e suas interpretações, nesta pesquisa, optamos por uma abordagem qualitativa, onde se busca a interpretação e análise dos fenômenos e situações observadas, considerando-se a imensa gama de valores, crenças, representações, opiniões e atitudes que os perpassam cotidianamente. (DEMO, 1990). Destaca-se que não se pretende a não manutenção do rigor necessário a qualquer pesquisa científica, mas sim a possibilidade de perceber e analisar as diversas facetas das realidades com as quais se está trabalhando.

Como nos diz Domingues:

A opção metodológica num trabalho científico não se caracteriza apenas por uma escolha de técnicas a serem aplicadas, mas, sobretudo, um processo de reflexão sobre o próprio ato de pesquisar em função do problema a ser estudado. Essa análise do método, quando mais criteriosa, cuida melhor da cientificidade dos trabalhos de pesquisa desenvolvidos na 
abordagem qualitativa, que não se coaduna com uma postura laissez faire, pois essa decisão determinará escolhas e a organização de etapas em função do que se quer observar e conhecer, na busca pela transcendência do senso comum. (DOMINGUES, 2009:33)

Assim, enfatizamos a importância dos processos de reflexão na construção metodológica da pesquisa, que conduzem a escolha das técnicas e o olhar que se terá sobre elas.

Utilizaremos uma abordagem qualitativa, sem excluir a compreensão da importância da abordagem quantitativa, no sentido de que esta possibilita apresentar e trabalhar com dados que possam trazer à tona indicadores, inclusive numéricos, que cooperem para interpretação e análise das realidades que se apresentam.

Embora exista a construção de hipóteses, a pesquisa qualitativa compreende que o próprio processo de observação, descrição e interpretação dos dados, pode levar a construção de novas hipóteses, pensadas durante o processo, assumindo a ideia de que quem observa ou interpreta - no caso o pesquisador - influencia e é influenciado pelas realidades que está pesquisando, numa perspectiva dialética de construção do conhecimento. Ainda segundo BOGDAN e BIKLEN (1982), pesquisas com abordagem qualitativa estão preocupadas em retratar a perspectiva dos participantes, levando-as em conta na análise dos dados.

Considerando-se que nas pesquisas em educação, as ideias e atitudes do pesquisador estão intimamente relacionadas às analises construídas, há que se ter cuidado com a objetividade e rigorosidade. O rigor científico, neste caso, está traduzido numa postura ética e na importância da socialização das análises e investigações.

Ainda que a pesquisa apresente uma metodologia, formas de sistematização para construção das análises, o debruçar-se sobre realidades educacionais e comunicacionais envolve os ambientes escolares, os sujeitos presentes nestes espaços e tempos, em todas suas diversidades, exigindo que se assuma esta pluralidade:

Os proponentes do paradigma qualitativo (...) assumem que há múltiplas realidades e não uma, cada uma relativa à experiência de quem a constrói, e que, portanto, a pesquisa subjetiva é a única possível. Como consequência, todos os estudos são influenciados por valores até um nível indeterminado. (OLIVEIRA-FORMOSINHO, 2002: 97)

Assim, assumimos nesta pesquisa que há uma relação entre quem pesquisa e o objeto/sujeitos pesquisados, de interpenetração de ideias e formas de ler o mundo. $\mathrm{O}$ 
quadro teórico permite uma sustentação da análise, para que possa se manter o rigor científico.

Tivemos como lócus da pesquisa dois momentos. Em primeiro lugar, esta pesquisa foi realizada nos cursos de formação inicial de professores, da cidade de Santos, junto a seis cursos de Pedagogia. Estudamos o projeto pedagógico dos cursos, na sua dimensão de quadros curriculares e ementas das disciplinas afeitas à interface entre educação e comunicação. Num segundo momento, trabalhamos com questionários com 113 professores da rede pública municipal, sendo estes professores de oito escolas, que trabalhavam em Ensino Fundamental I, para saber como viam seu trabalho com mídias nas escolas em que atuavam.

A proposta é observar se os professores, em suas práticas pedagógicas nas escolas, estão trabalhando com questões comunicacionais midiáticas. Busco compreender as referências da formação inicial em relação ao trabalho docente nas escolas, analisando se os currículos de formação docente estão elaborados de forma a contribuir para o preparo dos professores em relação as exigências colocadas pelas sociedades midiáticas da atualidade.

Diante dessa proposta, trabalho, como instrumentos, com a análise documental projetos pedagógicos, diretrizes curriculares do curso de Pedagogia, quadros curriculares e ementas de disciplinas. Também foram utilizados como instrumento de pesquisa os questionários com os professores. Ainda temos como instrumento de coleta de dados a observação da pesquisadora nas escolas em que aplicou os questionários, nas reuniões pedagógicas de professores e com a equipe técnica das escolas. Essa multiplicidade de métodos busca uma melhor compreensão da realidade estudada.

A análise dos dados segue-se à elaboração descritiva e interpretativa das evidências percebidas durante a fase da coleta. Quando se retomam os dados, aparecem temas recorrentes, que orientam a elaboração das categorias de análise e que nortearão a interpretação e construção conceitual. No momento da análise dos resultados, é importante uma primeira leitura, que favoreça o contato com impressões e permita a enunciação das categorias e a indicação de possíveis hipóteses para análise dos dados.

Como afirma ANDRÉ e LUDKE (1986: 48): “o primeiro passo na análise é a construção de um conjunto de categorias descritivas. O referencial teórico do estudo fornece geralmente a base inicial de conceitos a partir dos quais é feita a primeira classificação dos dados". 
Assim, faz parte da análise a leitura e releitura do material coletado, para que o pesquisador possa ficar impregnado do conteúdo. Embora o trabalho seja a análise realizada por meio de categorias, destaca-se a atenção para a relação entre todos os elementos evidenciados pelos dados, de maneira a não se perder a visão da totalidade. Também é importante considerar, conforme ANDRÉ e LUDKE (1986), não só o material explícito, recorrências, mas também o que está implícito, ou seja, o conteúdo latente, que pode apontar contradições e temas silenciados pelos sujeitos. Nessa pesquisa, destaca-se que diante de algumas das questões, tanto abertas como fechadas, os sujeitos deixaram a resposta em branco, me fazendo refletir sobre o que querem dizer os silêncios, aquilo que não é pronunciado. Os silêncios também trazem indicativos de formas de perceber e expressar a realidade. Podemos dizer que, dentro das ideias da multirreferencialidade, é importante perceber que o não dito compõe a totalidade, compõe o sistema de referências que pode nos ajudar a entender as realidades com as quais se está trabalhando. Aquilo que não é explicitamente falado, também é carregado de sentidos e enunciados. Isto é especialmente verdadeiro em nossas escolas, onde muitas vezes, em função de como estão estruturadas as relações de poder, alunos e professores se calem, sendo seu silêncio, talvez, possível de ser entendido como forma de resistência e contestação.

Considerando estas ideias, acima citadas, no processo de categorização dos dados, busquei estabelecer novas conexões, propondo interpretações e explicações, na construção de novas perspectivas teóricas, mas também deixando "fios" que permitam o entrelaçamento de novas "redes", em novas pesquisas e estudos, mantendo o constante movimento e transformação dos nossos conhecimentos. Este processo de categorização, esta tessitura, emerge tanto dos dados, ou seja, das realidades, dos cotidianos, quanto da teoria, pois no momento em que me debruço sobre as leituras, percebo lacunas quanto às ideias que venho trabalhando bem como também aspectos recorrentes, que demonstram existir maior necessidade de reflexão. O mesmo movimento acontece na pesquisa de campo, quando, ao trabalhar com a multiplicidade de aspectos que emergem dos dados, notam-se algumas evidências, que nos remetem a novas questões e construções teóricas, num movimento constante de diálogo entre a prática e a teoria.

Para ampliar a reflexão sobre as interfaces entre educação e comunicação, relacionadas à formação de professores polivalentes e aprofundar a compreensão de quais temas estavam mais em evidência nos estudos da área, favorecendo a construção 
do problema de pesquisa, foi necessário investigar as produções científicas que tratavam desta temática, realizando um levantamento bibliográfico. Este levantamento foi feito considerando-se a produção acadêmica quanto às dissertações e teses desenvolvidas e defendidas entre 2000 e $2009^{5}$ que tratavam das relações entre educação e comunicação, mais especificamente da formação inicial de professores e sua relação com aprendizagem em sociedades midiáticas. A pesquisa bibliográfica ainda foi realizada em produções de periódicos da área de educação, entre 2000 e 2009, consideradas os avaliados pela CAPES como Qualis A e B. Ainda neste processo de revisão bibliográfica da temática em questão, foram investigados os trabalhos apresentados na ANPED - Associação Nacional de Pós Graduação em Educação ${ }^{6}$, entre os anos de 2000 e 2009, no grupo de trabalho - GT - Comunicação e Educação e no grupo de trabalho Formação de Professores, este nos três últimos anos, ou seja, entre 2009 e 2011.

O panorama encontrado no levantamento bibliográfico, quanto aos estudos apresentados nas dissertações e teses, nos indica que na interface entre educação e comunicação, em especial no que tange a formação inicial de professores, ainda é incipiente a produção acadêmica. Os poucos trabalhos encontrados indicam que, de forma geral, os professores ainda não concebem as mídias - TV, Computador - como parte integrante do rol de linguagens que podem ser utilizadas e trabalhadas nas escolas, bem como há um desconhecimento dos professores em seus processos de formação inicial quanto à relevância do papel da escola como mediadora crítica diante das mídias.

A revisão bibliográfica realizada nas dissertações e teses também apontou um crescimento na área da educomunicação nos últimos anos, mas ainda assim, só um trabalho tratava da questão da formação de professores.

Quanto à revisão do tema realizada nos principais periódicos da área de educação, percebe-se que existem temas recorrentes nas diversas revistas analisadas, geralmente apontando para os impactos das mídias sobre as crianças e buscando estabelecer conexões entre as áreas de comunicação e educação, formas de aproximação e diálogo, um aspecto que ressalto no meu trabalho de pesquisa. Alguns trabalhos publicados buscam aproximar as áreas de educação e comunicação, tanto na linha teórica dos Estudos Culturais, estabelecendo conexões entre educação e processos de

\footnotetext{
${ }^{5}$ Levantamento bibliográfico realizado no Portal da Biblioteca Digital de Teses e Dissertações do Instituto Brasileiro de Informação em Ciência e Tecnologia - IBICT, vinculado ao Ministério da Ciência e Tecnologia: http://bdtd.ibict.br/

${ }^{6}$ Endereço do Portal da ANPED: http://www.anped.org.br/
} 
comunicação, enquanto instâncias produtoras de cultura e sentidos sobre o mundo, bem como na área de mídias e educação, com discussão sobre como a TV pode estar presente no cotidiano das escolas, apontando a necessidade da construção de políticas educacionais que aproximem a realidade da comunicação da realidade das escolas.

Interessante apontar que o periódico que tem produções em maior número e variedade sobre a interface entre educação e comunicação é a Revista Comunicação e Educação, publicação da Escola de Comunicação e Artes (ECA) da USP, ou seja, uma publicação da área de comunicação, mais especificamente do grupo ligado às propostas de educomunicação. Neste periódico aparecem diversas abordagens sobre as implicações dos contextos comunicacionais midiáticos e suas linguagens para o cotidiano das escolas e dos processos escolares, apontando na direção da necessidade de elaboração de políticas públicas que aproximem as áreas de educação e comunicação, construindo diálogos que possam favorecer o trabalho da escola e dos professores nas sociedades contemporâneas.

Os trabalhos, apresentados no GT de Comunicação e Educação da ANPED, que foram pesquisados, apontam para uma diversidade de temas, dentro das inúmeras possibilidades das duas áreas do conhecimento. Há uma preocupação, em alguns trabalhos analisados, com a produção cultural das sociedades atuais e como esta produção pode ser trabalhada nas escolas e ser apropriada pelos professores.

Na revisão dos trabalhos apresentados no GT Formação de Professores, aparece pouquíssima produção sobre a relação entre formação docente e trabalho pedagógico com mídias nas escolas, o que acentua a necessidade de desenvolvermos pesquisas nesta área, com produção científica que colabore para um maior diálogo entre as áreas de educação e comunicação.

De forma geral, a pesquisa bibliográfica realizada evidencia que há poucos estudos sobre formação inicial de professores em relação com as demandas colocadas pelas sociedades midiáticas atuais, com produções culturais simbólicas, que trazem impactos para as formas de ensino e aprendizagem nos processos educacionais e escolares.

Ainda que o olhar de alguns pesquisadores esteja voltado para a relação entre mídias e formação de professores, há necessidade de aprofundar os estudos, incorporando novas problemáticas e construindo novas relações entre as áreas de educação e comunicação. 
Este trabalho encontra-se organizado em capítulos, sendo o primeiro referente às crianças e sua inserção no mundo atual, buscando compreender como as transformações sociais e culturais atingem a forma de ser das crianças, exigindo um repensar dos processos de formação docente. Ainda neste capítulo apresento um breve repensar da escola num mundo tecnologizado e midiático. O segundo capítulo discorre sobre a formação de professores, diante da legislação atual e dos estudos que vem sendo realizados na área, em função das demandas sociais, analisando propostas pedagógicas de cursos de formação inicial de docentes, quanto ao diálogo entre educação e comunicação. O terceiro capítulo discute a interface entre processos educacionais e comunicacionais, inclusive como se apresenta esta interface nas ementas de disciplinas de cursos de Pedagogia, que preparam professores para os anos iniciais do ensino fundamental. No quarto capítulo dialogamos com dados coletados em questionários aplicados a professores sobre como percebem sua prática pedagógica com mídias nas escolas. Por fim, nas considerações finais, buscamos apresentar algumas ideias sobre a formação de professores em sociedades midiáticas, diante das transformações tecnológicas e culturais vivenciadas contemporaneamente. 


\title{
CAPÍTULO 1. UM MUNDO TECNOLOGIZADO E MIDIÁTICO: CRIANÇAS E EDUCAÇÃO ESCOLAR EM NOVOS CONTEXTOS DE COMUNICAÇÃO
}

\begin{abstract}
...nem os meios são o inimigo (ao contrário) da educação, nem estão destruindo ou substituindo a escola; o que os meios fazem é desorganizar a hegemonia da escola desafiando sua pretensão de continuar sendo o único espaço legítimo de organização e transmissão de saberes. O que obriga a situar a relação escola-meios para além do debate sobre os efeitos morais ou ideológicos, sendo necessária entendê-la no âmbito das modificações na cultura e na sociedade, nas mudanças que ligam as novas condições do saber com as novas formas de sentir e as novas figuras da sociedade (Martín-Barbero)
\end{abstract}

Pretendo, neste capítulo, refletir sobre a situação das crianças e da educação escolar neste começo de século XXI em sua relação com a sociedade atual, altamente tecnologizada e midiática. Os processos educacionais e escolares sempre desempenharam uma função primordial em nossas diversas organizações sociais, sendo responsáveis, entre outras nuances, pela socialização dos indivíduos - em especial pela socialização das crianças -, pelo desenvolvimento de formas de relacionamento humano e maneiras de conceber e lidar com informações e conhecimentos. Para pensarmos o papel da escola, principalmente da escola pública, em nossa sociedade, localizada temporalmente no início do século XXI, e como esta escola está dialogando com seus alunos, precisamos pensar em como está estruturada esta mesma sociedade, quais são os movimentos que a constroem cotidianamente, quais são seus pilares e como estes estão relacionados à nossa construção enquanto indivíduos pertencentes a esta sociedade.

Entre outros autores, MARTÍN-BARBERO (1996) suscita uma reflexão pautada no âmbito das modificações na cultura e na sociedade, pois estas modificações também trazem outra conotação às condições do saber, impactando as formas de sentir e perceber a sociedade, as formas de aprender e apreender o cotidiano. Portanto, trazem implicações para as formas de ensinar e aprender, as formas com as quais trabalhamos nos processos educacionais e escolares, com os alunos que estão hoje em nossas escolas.

Para pensarmos qual escola queremos para o século XXI, precisamos refletir sobre o momento que vivemos. Qual contexto vivemos neste início de século XXI? De 
qual mundo estamos falando? Nos construímos como cidadãos, como educadores, em qual situação social, econômica e cultural?

\subsection{Uma sociedade conectada}

A humanidade está vivenciando uma situação paradoxal. Ao mesmo tempo em que assistimos a um considerável avanço dos conhecimentos, da ciência e das tecnologias de comunicação e informação, há um aumento das disparidades sociais, acirramento das guerras por questões locais e disputa de territórios, por diferentes crenças e formas de pertencimento social e cultural. Há que se pensar a educação e os processos escolares diante desta realidade que temos hoje: mundo globalizado, com desigualdades sociais, onde ocorrem processos de mundialização da cultura e avanços tecnológicos sem precedentes na história da humanidade.

Marc Augé, ao falar de mudanças no mundo atual, fala sobre mudanças na maneira de olhar: "o que confirma a hipótese segundo a qual a relação dos seres humanos com o real se modifica pelo efeito de representações associadas com as tecnologias, com a globalização e com a aceleração da história.” (AUGE apud em MARTÍN- BARBERO e REY, 2004:07)

Portanto, temos hoje, também em função do processo de globalização e do desenvolvimento das tecnologias, nossas formas de relação com o real alteradas. Nossas representações de mundo, nossas relações com outros seres humanos estão perpassadas pelas tecnologias, num processo que atinge a todos nós. Vejamos o que SOARES (1996) nos alerta sobre globalização:

Globalização não é um processo recente, como se poderia supor, mas representa um processo de larga maturação, com ciclos de retração, ruptura e reorientação, em que antigos costumes se mesclam com novos signos. Na atualidade, pode ser descrita a partir de algumas características vinculadas às relações econômicas, à ideologia política, à língua predominante e aos modos de comunicação. (SOARES, 1996:9)

Portanto, a globalização pode ser descrita, refletida, a partir de algumas características, entre elas, os modos de comunicação. Estes modos de comunicação vêm passando por aceleradas mudanças nos últimos anos, com estas transformações vinculadas aos avanços tecnológicos. 
Os países mais desenvolvidos, considerados potências mundiais, investem em tecnologia, informática, robótica e novos meios de comunicação como uma maneira de divulgar informações num nível global, de maneira padronizada, também como forma de incremento da produtividade. Os meios de comunicação, entre outras facetas, divulgam as vantagens do sistema capitalista e do livre-mercado, muitas vezes colaborando para que as pessoas acreditem ingenuamente que o mundo de avanços, de progresso está ao alcance de todos.

A revolução tecnológica comunicacional amplia, cada vez mais, a capacidade de produção, acumulação e veiculação de dados e informações. Este processo todo, vinculado a globalização, não se restringe à economia. Também atinge os processos de produção cultural. Os chamados bens simbólicos são difundidos por meio de filmes, programas de TV, rádio, livros, revistas, jornais. Estes bens também ficam submetidos às práticas econômicas e alimentam o imaginário e a representação social dos indivíduos.

Ocorre, portanto, não só uma globalização da economia, mas também uma mundialização da cultura. Hoje vivemos uma situação paradoxal: mesmo com a diversidade cultural existente, assistimos a certa pasteurização cultural: os jovens brasileiros gostam do mesmo hambúrguer que os jovens norte-americanos; o jovem asiático ouve o mesmo 'som' que o jovem europeu; o adolescente brasileiro deseja usar o tênis norte-americano... Há uma homogeneização do gosto, o que coloca o risco de perdermos a riqueza da diversidade cultural.

Os conteúdos simbólicos, assim mundializados, atendem aos ditames da indústria cultural e da publicidade comercial. Acabamos por ter diante de nós uma cultura fragmentada, em que a cultura local fica perdida em relação a si mesma, pois é reelaborada em nível global.

Portanto, a globalização está diretamente relacionada à revolução tecnológica dos meios de comunicação. Enquanto o avanço na tecnologia permite a produção, armazenamento e a difusão de informações, a economia e o neoliberalismo dão as normas de quem poderá usufruir tanto dos bens materiais, como dos bens simbólicos.

Assim, uma das modificações presentes nos novos contextos sociais e culturais, sobre a qual temos que refletir, principalmente nos impactos que trazem para a educação, refere-se às mudanças tecnológicas, especialmente os meios de comunicação, que nos trazem novas formas de aproximação/apropriação da realidade. 
Estas mudanças tecnológicas, incluindo as chamadas novas tecnologias de informação e comunicação, são uma realidade a partir dos anos 1950.

Inúmeros autores apontam as novas tecnologias, que invadiram o mundo a partir da segunda metade do século XX, como as desencadeadoras das fantásticas mudanças que observamos hoje em todos os domínios da nossa existência. (COSTA, 2009: 63)

Portanto, estamos falando de mudanças recentes historicamente. São transformações tecnológicas comunicacionais que fazem parte de nosso cotidiano a partir de meados do século XX. Considerando que estamos no início do século XXI, várias destas mudanças não nos impactavam, em nossas organizações sociais, culturais, educacionais, no início do século passado.

Pensemos em algumas dessas mudanças tecnológicas, em especial na área de comunicação. Hoje temos telefonia móvel - celulares -, que não só nos permitem falar com outras pessoas, mas são aparelhos que recebem e enviam dados, mensagens, que nos permitem ver a programação de canais de TV. Nosso sistema de TV nos permite a assinatura de canais, com acesso a informações e entretenimento 24 horas por dia. A realidade da TV digital, interativa, desenvolve-se rapidamente, permitindo novas produções. Há uma convergência entre as diversas mídias, que tende a crescer nos próximos anos, permitindo que uma tecnologia adapte-se a outra, oferecendo novos suportes e possibilidades de produção e difusão de informações. A rede mundial de computadores nos permite conexão com todo o mundo, a qualquer momento, nos aproximando de outras formas de percepção das realidades espaço-temporais.

Nossas relações estão e são mediatizadas pelas tecnologias, novas formas de comunicar-se uns com os outros fazem parte de nosso cotidiano. Há um bombardeamento de informações, que nos chegam por diferentes vias, por diferentes telas. O conceito de novas telas - trabalhado por OROZCO (2009) - nos fala desse mundo a que temos acesso pelas telas: a tela da TV, a tela do computador, a tela do cinema, a tela do celular, a tela do I-pod, do MP 3, MP4, MP5, a tela do tablet, do ereader. Em geral, são telas pequenas e portáteis. Ou seja, aonde vamos, carregamos a possibilidade da informação conosco, a possibilidade de comunicação, de estarmos conectados a acontecimentos, ideias, emoções. Uma verdadeira invasão de nossos espaços e tempos cotidianos!

Participamos dos acontecimentos cotidianos mesmo sem estarmos diretamente presentes aos mesmos. As telas nos trazem representações destes acontecimentos. Já 
colocava DÉBORD, em 1967: toda a vida das sociedades nas quais existem as condições modernas de produção pode ser entendida como uma imensa sucessão de espetáculos. Tudo o que era diretamente vivido se afastou numa representação. (DÉBORD, 1967)

Interessante observar que sei, por exemplo, o que está acontecendo no Amazonas - estando em São Paulo - ao olhar para uma tela de computador, ler a notícia, ver alguma imagem acoplada a mesma, escutar uma narração e pronto! Estou supostamente informado a respeito de outro local, de algum acontecimento, mesmo sem ter vivido, visto este acontecimento. Este é um aspecto que nos convoca a reflexão: $\mathrm{O}$ que esses processos de produção e circulação de informação e comunicação significam? Como essas formas de comunicação virtual, rápidas, instantâneas, podem afetar nosso jeito de constituir nossa humanidade? Como essa revolução tecnológica, que nos chega por inúmeras telas, muda nossas formas de perceber o mundo, refletindo também em processos educacionais e escolares, em nossos processos de formação enquanto seres humanos?

A revolução tecnológica, em especial a comunicacional, também invadiu nossas relações de trabalho e lazer. Com a possibilidade de envio instantâneo de dados, informações, com a comunicação imediata favorecida pelas novas mídias, as empresas podem ter base num determinado país e operar em outros países. Já temos o conceito de Home Office, onde algumas pessoas não precisam mais deslocar-se cotidianamente para o trabalho; podem realizar parte dele em suas casas, fundindo ambientes de trabalho e de moradia. Nosso lazer está ligado a inúmeras mídias, que nos permitem entretenimentos como vídeo game, sites de bate papo, assistir filmes em DVD, via tela de computador. As possibilidades são muitas e sempre com acréscimo de novidades, patrocinadas pelo mercado e pelo consumo incentivado pelo próprio regime capitalista. Esta não é uma realidade que fica distante das classes populares, pois há todo um mercado informal, onde são vendidos games, DVDs piratas, CDs com as últimas gravações de artistas e bandas. Mesmo nas favelas Brasil adentro, existem as lanhouses, os cyber cafés, montados nos mercadinhos e vendinhas, que permitem acesso a rede mundial de computadores. Os canais de TV apresentam incansavelmente todas as novidades tecnológicas, destacando inúmeras possibilidades de compra e financiamento. Mesmo num país como o Brasil, com índices altos de exclusão social, a realidade de uma sociedade cada dia mais perpassada pelas tecnologias e novas formas de produção 
e divulgação de informações pode ser percebida em nossos cotidianos. Cabe destacar que, diante deste cenário de transformações tecnológicas, há uma preocupação do governo federal em relação a como inserir escolas, alunos e professores neste cenário. As políticas públicas educacionais têm apresentado propostas diversas de introdução de computadores nas escolas, para permitir a navegação na internet para alunos e professores, inclusive tem sido apresentadas propostas de financiamento para que os docentes possam comprar computadores pessoais. Há programas específicos de aperfeiçoamento dos professores como é o caso do $\mathrm{PROINFO}^{7}$, para que os docentes possam ser preparados para estes novos cenários de um cotidiano perpassado por diversas mídias.

Hoje, podemos dizer que os mundos sociais e simbólicos estão articulados e subordinados às tecnologias, emergindo delas as formas de viver e estar no mundo. (POSTMAN, 1999)

Ou seja, nossas relações sociais estão atravessadas pelas tecnologias e a construção de nossas representações de mundo também. Os bens simbólicos são amplamente divulgados pela rede de mídias, que colabora também na construção de nossas formas de percepção do mundo em que vivemos e das relações que construímos.

$\mathrm{O}$ excesso de informação, as formas emergentes de comunicação e interação interpessoal, a convocação pelas mídias, as novas versões de entretenimento, entre tantas outras experiências deste 'admirável mundo novo', estão mudando a maneira de ser das crianças e dos adultos, embaralhando tudo o que achávamos que tinha um lugar certo, verdadeiro e lógico para acontecer. (COSTA, 2009: 61)

Autores como BAUMAN (2007), chamam nosso tempo de líquido. Algo que nos escapa, que parece escorrer por entre nossas próprias mãos, sem concretude. Nesta sociedade líquida nossas identidades também são cada vez mais cambiantes, múltiplas, sempre em processo de definição. Nossas certezas da chamada época da modernidade estão em questionamento. Em nossa sociedade atual, a que vivemos depois do período da modernidade, a pós modernidade, estamos perplexos não só com as mudanças, mas também com a velocidade em que essas mudanças se processam.

Segundo Veiga Neto:

\footnotetext{
7 PROINFO: O Programa Nacional de Tecnologia Educacional (ProInfo) é um programa educacional criado pela Portaria ${ }^{\circ}$ 522/MEC, de 9 de abril de 1997, para promover o uso pedagógico das tecnologias de informática e comunicações (TICs) na rede pública de ensino fundamental e médio.
} 
É claro que jamais a história humana parou, que jamais qualquer sociedade ou grupo humano ficou estacionado no tempo. Mas, por outro lado, jamais as mudanças aconteceram na velocidade e com a intensidade que hoje se observam. Mudanças - de costumes, práticas e valores culturais - que demoravam séculos para acontecer, hoje nos atravessam em poucos anos, de modo que, mesmo no curto período de uma vida, podemos experimentar muitas transformações que eram impensadas até o momento de ocorrerem. (VEIGA NETO, 2004: 159)

A velocidade das transformações nos deixa sempre com uma sensação de inacabamento, de não entendimento das situações, de estarmos apressados para fazermos algo que nem sempre sabemos exatamente o que é. VIRILIO (2000) afirma que nossas sociedades são dromológicas, ou seja, regidas pela velocidade.

Estamos, em nosso cotidiano, sempre buscando fazer as ações e atividades de forma mais rápida, querendo chegar rápido aos lugares, resolver as situações em pouco tempo. Podemos dizer que estamos vivendo uma vida acelerada! Esta vida acelerada envolve nossas relações com outros seres humanos, envolve nossas tarefas cotidianas, nosso descanso, nossas produções nos diferentes ramos de trabalho. Essa aceleração também está relacionada a nossos processos educacionais e escolares.

As tecnologias a que temos acesso modificam nossa organização dos espaços e tempos. Temos acesso a informações 24 horas por dia, nos mais diferentes suportes. Podemos estar informados pela televisão, pelos jornais, pela Internet. São tantas informações que não temos tempo hábil de lidar com todas, de processá-las, de conseguir articulá-las para que não sejam somente informações, mas que possam nos ajudar realmente a perceber o mundo e refletir sobre ele. Este imenso volume de informações também chega às crianças do nosso tempo, nas mais variadas formas, nos mais diversos suportes.

\subsection{Crianças num mundo conectado:}

Comecemos a imaginar este mundo de transformações em relação às crianças e jovens, aqueles com os quais trabalhamos em nossas escolas. São nascidos neste mundo tecnológico, acelerado, em constante mudança.

Autores como PRENSKY (2006) criaram um nome para as novas gerações: nativos digitais. Crianças - tanto das classes mais ricas quanto das classes populares - 
nascidas na era do desenvolvimento rápido das tecnologias e que operam essa tecnologia, muitas vezes de forma simultânea: assistem TV, ao mesmo tempo em que fazem a lição da escola, em que estão com a tela do computador à sua frente transmitindo informações e possivelmente também escutando música. Prensky afirma que as sinapses - ligações neuronais - desses meninos das novas gerações são mais rápidas do que eram anteriormente, numa velocidade que não é a mesma dos professores, que estão na chamada geração dos migrantes digitais.

Citelli apresenta a ideia de Prensky:

A ideia da existência de migrantes digitais e nativos digitais. Os primeiros marcados por uma cultura analógica, cujo aparelho perceptual e cognitivo trabalha, ainda, à base dos mecanismos lineares; os segundos formam os segmentos mais jovens, cuja forma mentis opera em ritmo rápido, com procedimentos mais próximos do aleatório (randômico), fundados nas linguagens digitais. (CITELLI, 2010: 20)

O raciocínio destes meninos e meninas, nativos digitais, se constrói na forma de hipertextos e não de forma linear, com começo, meio e fim. Fazem justaposições entre as diversas informações com as quais estão operando, numa lógica textual diversa da que costumamos utilizar, nós, nascidos e criados em outra geração, num mundo menos tecnologizado e midiático. A maioria dos professores que estão trabalhando hoje nas escolas não nasceu na era da tecnologia e não operam facilmente com a mesma, tendo um raciocínio muito mais pautado na linearidade do que nos hipertextos. Por isso são chamados de migrantes digitais. A tecnologia não é algo que nasceu com eles, mas tem que adaptar-se cotidianamente a ela. Estes professores, que não são nativos digitais, trabalham e dialogam a respeito do mundo com os nascidos na era tecnológica!

$\mathrm{O}$ avanço da tecnologia também permite atualmente a chamada convergência das mídias. Enfrentamos novos produtos audiovisuais, com novas lógicas de produção e difusão de informações e imagens. Há outras lógicas quanto às linguagens, não lineares, superpostas, que exigem destrezas especificas para entendê-las, articulá-las. O cenário atual exige aprendizagens múltiplas com novas linguagens e novas lógicas de produção. Pensar essas novas lógicas é pensar que elas modificam os processos de comunicação e informação, pautados também nas múltiplas possibilidades de emissão e não somente em processos de recepção.

Essa é uma faceta das mudanças que vemos acontecer: a tecnologia é a linguagem quase natural das novas gerações. Uma linguagem que operam mesmo sem 
saber as implicações que essas operações podem ter para suas formas de percepção do mundo em que vivem.

Portanto, um aspecto a ser considerado neste mundo em transformação é a forma como as crianças e jovens vivem suas experiências de vida cotidianas. Costa (2009) nos fala que com as transformações ocorridas após 1950, com o desenvolvimento das grandes corporações empresariais, estas corporações passam a criar uma cultura infantil. Nas palavras da autora: "as crianças de hoje são, antes de tudo, subjetividades forjadas em uma cultura regida pelos apelos do mercado". (COSTA, 2009:65).

Em nossas sociedades atuais, onde as economias estão globalizadas, somos incentivados sempre mais a práticas de consumo. Tudo é tratado como mercadoria, inclusive os processos culturais e educacionais. O nosso sistema de televisão é mantido pela publicidade, com propagandas dos mais diversos produtos, que pagam para inserção das propagandas na grade de programação e, assim, mantém os programas no ar. Se pararmos um momento para pensar em quais propagandas circulam no espaço de um programa infantil, como os desenhos animados, vamos perceber que são propagandas de grandes corporações: temos salgadinhos da Elma chips, Danoninho, Coca Cola, Mc Donald's e uma infinidade de apelos ao consumo.

Ao serem questionadas se preferiam brincar ou ver televisão (pesquisa realizada pelo Instituto Alana ${ }^{8}$, para produção do vídeo “Criança, a alma do negócio”), as crianças respondem: ver televisão. Momentos depois são apresentados às crianças vários legumes e frutas. As crianças não identificam mamão, beterraba ou manga. Em seguida, os entrevistadores apresentam as crianças pacotes de salgadinhos industrializados, sem os nomes, sem os rótulos. As crianças acertam todos os nomes!

BARBER (2009) afirma que a última fase do capitalismo é o chamado capitalismo de consumo, que traz consigo uma ética de infantilização, onde o protagonista principal é um consumidor compulsivo. Nas palavras do autor:

O mundo do capitalismo de consumo (...) dominado pela ética do infantilismo e que tenha como protagonistas consumidores juvenis incapazes de alcançar a liberdade dos cidadãos (...). É difícil resistir ao recente capitalismo de consumo, ou mudá-lo, porque ele cria uma ilusão de liberdade privada que resulta numa coerção invisível e torna o exercício da liberdade pública mais difícil. (BARBER, 2009; 67-68)

\footnotetext{
${ }^{8}$ O Instituto Alana é uma ONG que desenvolve atividades em prol da defesa dos direitos das crianças e dos adolescentes relacionadas a relações de consumo em geral, bem como ao excessivo consumismo ao qual são expostos.
} 
Esse capitalismo de consumo atinge a todos nós, mas obviamente, atinge mais as crianças e adolescentes, atinge mais os que estão em processo de formação e construção de suas identidades.

Pensemos no cotidiano das nossas crianças. É um cotidiano atravessado pelas mídias. Assistem TV, jogam games na tela do computador, mandam mensagens pela tela do celular, escutam musicas com seus Ipods. Se falássemos para as crianças que alguns de nós fomos crianças num mundo sem TV ou internet, elas teriam dificuldade em entender como seria o dia a dia.

Costa nos fala de

Relatos que dizem respeito a certos atravessamentos de artefatos culturais contemporâneos na vida escolar. Uma aproximação com vistas a obter mais detalhes sobre tais acontecimentos tem descortinado um vasto e novo repertório da cultura pós-moderna, predominantemente midiática, que se insinua na vida das pessoas, alterando as rotinas e as práticas cotidianas no interior de instituições consagradas como é o caso da família e da escola. (COSTA, 2005: 3)

As crianças são apresentadas a uma série de representações de mundo, de ideias quanto aos jeitos de ser humano nos inúmeros programas que assistem. Toda essa cultura midiática está incorporada ao nosso cotidiano e nos apresenta novas formas de nos relacionarmos uns com os outros, novas formas de estarmos informados e interagirmos.

Nas palavras de Buckingham:

As mídias eletrônicas têm um papel cada vez mais significativo na definição das experiências culturais da infância contemporânea. Não há mais como excluir as crianças dessas mídias e das coisas que elas representam. (...) Precisamos agora prestar muito mais atenção em como preparar as crianças para lidar com essas experiências. (BUCKINGHAM, 2007:32)

As crianças, nascidas e criadas nesse ambiente altamente tecnológico, midiático, adaptam-se ao mesmo. São capazes de operar várias tecnologias ao mesmo tempo. Algumas pesquisas (Núcleo de Pesquisas da Psicologia em Informática - NPPI PUC/SP, 1995) têm apontado que as sinapses das crianças estão mais rápidas do que antes, que a interatividade ocorre de novas formas, o que também nos obriga a repensar os processos de ensino e aprendizagem, que devem estar mais pautados nas possibilidades de diálogo e interação, entre alunos e professores. Obviamente, 
raciocínios mais rápidos não quer dizer que são raciocínios articulados ou elaborados com profundidade. Importante perceber as mudanças e refletir sobre as mesmas, de forma a buscar formas de construção do pensamento e elaboração das informações que permitam articular as informações em conhecimento, em formas de entender e intervir no mundo em que vivemos.

Outra citação de Costa corrobora essa ideia de uma infância relacionada à tecnologia:

Crianças pequenas que recém entraram na escola já conseguem operar com mais competência no universo tecnológico em que vivemos do que boa parte de seus pais e professores (...) às vezes nos surpreendemos incapazes de decifrar certos textos televisivos, certas propagandas, certos jogos, certos filmes, certas práticas, certos comportamentos, certas mensagens, exatamente porque fogem inteiramente ao nosso universo de referência. Há outra gramática cultural em andamento. Esse é o maior desafio de todos para a educação de hoje. (COSTA, 2009: 69)

A educação, principalmente a educação escolar, pode favorecer que nos assumamos criticamente como receptores/usuários destas novas formas de gramáticas culturais, midiáticas. Que nos assumamos também como emissores nestas novas lógicas, como comunicadores, que nos expressamos em múltiplas linguagens e lógicas, para interagirmos de maneira adequada com todos que estão sintonizados em redes de comunicação social, nos mais diversos suportes, que perpassam nossos cotidianos.

Portanto, estamos falando de um mundo em mudanças, em diversos níveis econômico, cultural, tecnológico - e como essas mudanças estão impactando as pessoas, em especial as novas gerações. Justamente as gerações com as quais trabalhamos em nossas escolas. Para pensar um pouco mais sobre as mudanças que vivemos e sua relação com a escola, pensemos qual papel a escola tem em nossa sociedade, como esse papel foi construído historicamente e como está situado nos dias atuais.

\subsection{Pensando a escola num mundo tecnologizado e midiático:}

O futuro ainda demora muito tempo? Nada mudou? Tudo mudou? Estamos num momento de transição. Pressentimos o fim de um ciclo histórico, iniciado em meados do século XIX, quando se inventou a modernidade escolar pedagógica. Mas temos dificuldade em abrir caminho à contemporaneidade. (...) 
A escola de hoje é infinitamente melhor do que a escola de ontem. É mais aberta, mais inteligente, mais sensível à diferença. Mas não chega. (Nóvoa, 2005:15)

A citação de Nóvoa nos ajuda a pensar o advento da chamada instituição escolar, seu percurso histórico e sua relação com nossa sociedade atual, atravessada por transformações rápidas, constantes, altamente tecnologizada e midiática.

Hoje temos uma situação singular na sociedade, em que a instituição escolar já não é a única ou a principal instituição a apresentar informações e formas simbólicas de perceber o mundo. A escola disputa com outras instâncias, em especial os circuitos comunicacionais, a construção de representações de mundo e as informações a que temos acesso.

Trata-se de um contexto singular que força a intensificação dos diálogos entre o dentro e o fora da sala de aula, requisitando dos ambientes educadores formais um novo tipo de tratamento, andamento e, sobretudo, estratégias didáticas e pedagógicas que não retirem dos seus horizontes de preocupações o fato de existirem outras dinâmicas a concertarem os processos de ensino-aprendizagem. (CITELLI, 2010: 20)

A escola, enquanto instituição social, ocupou durante muito tempo, um papel primordial na organização das sociedades, em especial das sociedades urbano industriais. Se remontarmos a época do desenvolvimento industrial no mundo, final do século XVIII e século XIX, veremos a importância da escola, naquele contexto, como formadora da mão de obra da nascente indústria. Uma maneira de formar rapidamente um contingente de mão de obra apto ao trabalho nas indústrias era uma formação em massa nas escolas. Não tínhamos, na época, outras formas de socializar os meninos e apresentá-los as informações necessárias a sua convivência social, senão instâncias socializadoras como a família e a escola. Portanto, temos um nascimento da escola ligado às questões econômicas, a expansão das sociedades urbano industriais.

Nas palavras de Veiga:

Para compreendermos a singularidade da história da educação escolar é preciso indagar como e por que historicamente a escola se estruturou de determinada forma e não de outra. Ou, ainda, nos perguntarmos como e por que a escola se estabeleceu na função de centralizar e normalizar os processos de produção e transmissão de conhecimentos e de socialização das gerações, em detrimento de outros espaços educadores da sociedade e de outros modos de aprendizagem. (VEIGA, 2007:10) 
Veiga nos apresenta um recorte interessante: a escola se estabeleceu, enquanto instituição social, na função de centralizar os processos de produção e transmissão de informações e conhecimentos, socializando as novas gerações, em detrimento de outros espaços educadores da sociedade. Portanto, percebemos o sentido da educação escolar como um sentido de socialização das crianças, de construção de cidadania, de apresentação do repertório cultural construído e acumulado pela humanidade, para que possam apropriar-se deste repertório e organizar suas experiências de vida.

Nas palavras de Julia, a escola era, desde os primeiros colégios: "não somente um lugar de aprendizagem de saberes, mas ao mesmo tempo, um lugar de inculcação de comportamentos e de habitus". (JULIA, 2001:22)

Assim, temos uma escola que, historicamente, vem cumprindo um papel social importante, quanto à forma de inserção das crianças nos costumes e hábitos sociais, quanto à instrução e normatização do cotidiano. Nessa instituição escolar, o papel central era - e ainda é - ocupado pelo professor, responsável direto pelas crianças e jovens, responsável direto pelos processos de socialização e de transmissão dos saberes acumulados historicamente pelas sociedades.

Citelli nos recorda que:

Os modelos escolares com os quais convivemosfrequentemente chamados, à falta de melhor termo, de tradicionais - estão construídos em torno de três eixos básicos: hierarquia, coerção, exclusão. A tendência, neste tipo de escola, foi a de elaborar programas educativos fechados em que não se ajustam comportamentos que possam levar à quebra das sequencias hierárquicas justificadas pela lógica da melhor escolha dos conteúdos e pela autoridade de quem os selecionou. Há que se ensinar, pois um conjunto de itens cuja pertinência se afirma como a única possível, sendo as vozes da fratura objetos de possíveis punições. (CITELLI, 2004: 84)

Nesse tipo de construção escolar, o professor assume um dos discursos considerados corretos e é o transmissor dos saberes as novas gerações. Não nos estenderemos sobre esses aspectos, mas o professor também está subordinado a normas e referenciais elaborados por órgãos oficiais - secretarias de educação, ministério da educação etc -, que apresentam um programa que deve ser cumprido. Sendo assim, temos vários elos compondo a organização e controle dos processos de ensino e aprendizagem, sendo a escola e o professor uma parte desses elos. Obviamente, não estamos questionando a necessidade de organização do sistema escolar, mas refletindo 
sobre a organização desse sistema, onde a maior parte das diretrizes e da escolha de conteúdos acontece fora das escolas, onde estão, no dia a dia, professores e alunos.

Se pensarmos no professor como mais um elo da corrente, não se pode afirmar que ele, professor, é alguém com autonomia o tempo todo para pensar as funções que desempenha. O professor tem uma autonomia relativa (Contreras, 2002) diante dos próprios processos docentes. Faz parte de um todo maior, pensado num contexto de uma determinada sociedade, que espera alguns procedimentos da escola e cobra esses procedimentos. Portanto, não há como descontextualizar as escolas da sociedade como um todo. Temos aqui uma via de mão dupla: as sociedades esperam algo da instituição escolar e conformam parte da instituição a interesses e objetivos da sociedade. Por outro lado, numa relação dialética, a escola também pode confrontar algumas normas sociais e apresentar outras possibilidades de organização.

Num país como o nosso, o Brasil, que tem alto índice de exclusão social, ainda temos que pensar outras circunstâncias a afetar os processos educacionais e escolares. Muitas de nossas escolas públicas estão sucateadas, em péssimo estado de conservação, com mobiliário não compatível com as necessidades cotidianas, com instalações precárias de laboratórios, quadras de esportes e bibliotecas. Muitas vezes as salas de aula estão sem iluminação adequada, sem nenhum recurso que possa colaborar para processos de ensino aprendizagem mais motivadores e eficazes.

Some-se a isso o baixo salário dos professores, que não favorece que professores possam comprar livros, participar de cursos e congressos de formação contínua ou mesmo ter hábitos de lazer que ampliem seu repertório cultural, possibilitando assim que também possam ampliar o repertório cultural de seus alunos.

Outro problema a afetar a escola no Brasil é o aspecto da exclusão social que enfrentam os nossos alunos:

Um dos aspectos problemáticos da escola que estamos discutindo envolve os mecanismos de exclusão. Alguns deles são gerados em espaços não escolares, caso de nossas conhecidas condições de miséria e desigualdades sociais que impedem muitas crianças de permanecer nas salas de aula. Frequentam uma ou outra série, passam pouco tempo nos bancos escolares e logo se vêem na condição de exilados a transitar pelas terras do trabalho infantil, do reforço do orçamento domestico. (CITELLI, 2004:92)

Libâneo (2010) apresenta uma análise da escola apontando um dualismo perverso: uma escola do conhecimento para os ricos e uma escola do acolhimento social 
para os pobres, onde se reproduzem as desigualdades sociais, contribuindo para um sucateamento da escola e da educação públicas. Há uma polaridade de posições quanto às funções sociais da escola em nossa sociedade,

Indicando o dualismo da escola brasileira em que, num extremo, estaria a escola assentada no conhecimento, na aprendizagem e nas tecnologias, voltada aos filhos dos ricos e, em outro, a escola do acolhimento social, da integração social, voltada aos pobres e dedicada, primordialmente, a missões sociais de assistência e apoio às crianças. (LIBÂNEO, 2010: 56)

Diante dessa compreensão da função social da escola como forma de assistência e apoio aos alunos, ocorre um empobrecimento da abordagem dos conteúdos curriculares, onde os alunos mais pobres - diante de uma escola do acolhimento - não tem acesso a conhecimentos que poderiam ampliar seus horizontes culturais, expandindo seu repertório de leitura de mundo.

Portanto, temos uma escola real em nossa sociedade, que apresenta problemas concretos, num quadro de dualidade e exclusão escolar. Escola que nasceu num determinado contexto histórico, o advento das sociedades urbano industriais, que se afirmou como instituição responsável pela transmissão de saberes acumulados historicamente, num horizonte de sociedade dividida em classes. Escola que construiu representações sociais quanto às funções da escola bem como representações quanto ao papel do professor como condutor quase exclusivo dos processos de ensinoaprendizagem.

Pensemos esta escola hoje, início de século XXI, numa sociedade complexa, estabelecida em diversas redes: redes sociais, redes de saberes e fazeres, cada vez mais múltiplos, com vozes plurais e com outras formas de transmissão de saberes, diferentes daquelas relativas ao século XIX e princípios do século XX. Uma sociedade, como já afirmamos, midiática, perpassada por novas formas de comunicação e interação entre as pessoas. Sabemos hoje que a socialização das crianças e jovens é atravessada por muitos fatores: a família, a escola, o grupo de amigos, as atividades na rua, os meios de comunicação, a igreja, os partidos, as associações de bairro. Não há uma única possibilidade de estar informado sobre o mundo: existe uma infinidade de possibilidades a conformar a identidade de cada um de nós em nossas experiências cotidianas. Parte delas é processada nas escolas. Outra parte de nossas experiências 
ocorre em ambientes múltiplos, com os quais é extremamente necessário que a escola dialogue. Nas palavras de Barbero:

Os meios de comunicação e as tecnologias da informação significam para a escola em primeiro lugar isto: um objetivo cultural, que torna visível a distância a cada dia maior entre a cultura que ensinam os professores e aquela outra que aprendem os alunos. Pois, os meios não apenas descentram as formas de socialização, de dispositivos de identificação/projeção de pautas de comportamentos, estilos de vida e padrões de gosto. E só a partir da assunção da tecnicidade mediática como dimensão estratégica da cultura que a escola pode insertar-se nos processos de mudança por que atravessa nossa sociedade. (MARTÍN-BARBERO, 1996:19)

Para que a escola em geral e, em especial, a escola pública, se repense como instituição e colabore no repensar da sociedade como um todo, precisa perceber a tecnicidade mediática como dimensão estratégica da cultura, portanto dimensão estratégica dos processos socializadores desenvolvidos nas escolas. Nas palavras de Pérez Goméz: "em la escuela tenemos que crear um espacio de vivencia de la cultura no um espacio de transmisión academicista de la cultura." (PÉREZ GOMÉZ, 2006:103). Ao assumir-se como espaço das mais diversas experiências culturais, a escola pode, muito mais do que transmitir conhecimentos, ser articuladora de saberes, de possibilidades de criação, de reinvenção do mundo em que vivemos.

O advento de novas formas de comunicação e informação, de novas tecnologias a atravessarem nossas experiências cotidianas, exige da escola um repensar sobre seu significado social e suas formas de atuação na construção de uma sociedade mais igualitária e democrática, com processos claros de inserção social cidadã. É um desafio ético para todos e, em especial, para os educadores, o repensar dos espaços públicos, de espaços coletivos, o repensar das funções e possibilidades da educação escolar.

Segundo Rosa Fisher:

Diria que se torna cada vez mais urgente a realização de um trabalho de leitura dos acontecimentos sociais e suas inúmeras versões (...) e, principalmente, à criação de espaços em que as crianças e adolescentes possam encontrar referências suficientes para aprender a organizar, selecionar e hierarquizar o imenso volume de informações, dados, imagens e sons e opiniões que recebem todos os dias. (FISHER, 2001:61)

A escola, muito mais do que um espaço de transmissão de saberes, pode ser um espaço para debate, para criação de novos saberes a partir das informações que todos recebemos todos os dias. Um espaço que permita a confrontação de ideias e 
perspectivas de mundo, colaborando para que os alunos sejam mais críticos diante das informações a que tem acesso. Um espaço que admita múltiplos discursos, que interagem entre si, levando a novas construções. Discursos de todos os envolvidos nos processos educacionais escolares: discurso de professores, de alunos, de funcionários, de pais, da comunidade que está no entorno da escola, das mídias, das inúmeras redes de saberes que existem em nosso cotidiano.

A escola, lugar privilegiado para educação escolar das novas gerações, está desafiada pela presença dos meios de comunicação em nosso cotidiano, conformando o espaço público.

As palavras de Bauman nos levam à reflexão: "O espaço público poderia ser transformado novamente num lugar de engajamento permanente em vez de encontros casuais e passageiros?” (BAUMAN, 2007:197)

Orozco também colabora em nossa reflexão quando afirma:

Os desafios educativos que nos colocam os meios de comunicação nos empurram a um dilema; ou enfrentamos os meios de comunicação de massa com astúcia, estratégia e métodos ou corremos o risco de perder relevância como educadores. Isto é, corremos o risco de ficar fora da jogada educativa. (...) temos que começar a jogar o que considero seja o jogo da mediação, entre os meios de comunicação, as instituições educativas e os processos de recepção de mensagens nos quais se envolvem nossos estudantes. (OROZCO, 1997:61)

A sociedade midiática do século XXI precisa de uma escola que amplie o repertório cultural dos alunos também quanto à sua posição de receptores dos meios de comunicação. O desenvolvimento da tecnologia nos possibilita hoje sermos usuários, ativos diante do que vemos e ouvimos, capazes de recriar a programação que nos chega pelos meios de comunicação em seus diferentes suportes e linguagens.

Os novos contextos que estão postos hoje nos trazem o desafio de repensar os processos educacionais e escolares. Os processos comunicacionais e educacionais estão cada vez mais relacionados entre si. OROZCO (2009) afirma que estamos numa sociedade do aprendizado. Passamos de uma escola com professores que cumpriam seu trabalho de transmitir conhecimento para uma escola onde a aprendizagem transcende o ensino. Esta é uma realidade para a qual temos que pensar em como preparar nossos professores, para que sejam protagonistas das transformações. Aprendemos em vários lugares, com consciência ou sem consciência dessa aprendizagem. Aprendemos 
conversando, vendo a lua, andando na rua. Aprendemos em contato com as telas da TV, do computador, do celular, presentes em nossos cotidianos.

A educação também resulta de intercâmbios que temos fora do sistema educativo escolar formal. É necessário problematizar essa situação. O que significa viver numa sociedade do aprendizado, onde só uma parte da aprendizagem é resultado da escolarização formal? Onde parte considerável da aprendizagem ocorre fora da escola, também por meio dos suportes de comunicação com os quais interagimos?

Nossas crianças, em seu cotidiano, passam mais tempo em frente às telas da TV e do computador, do que em nossas escolas. Ocorrem outras aprendizagens, em espaços diversos do espaço escolar formal. Temos colocado o desafio de outras formas de educação, diferente das usuais, diante das mudanças que percebemos em nosso mundo.

Com os avanços e transformações tecnológicas, os processos de comunicação e seus suportes também passaram por profundas mudanças. Hoje temos a possibilidade, diante da programação oferecida pelas mídias, de sermos emissores, não somente audiência. Podemos criar blogs, escrever textos e publicá-los, podemos fazer gravações de filmes com nossos aparelhos celulares e postá-los no you tube, para que outras pessoas assistam. Os meios de comunicação, em suas novas possibilidades, nos tornaram, simultaneamente, receptores e emissores. Essa mudança de receptores a emissores implica novos papéis sociais e culturais, novos papéis educacionais e escolares.

Nessa dimensão de processos de transformação na qual estamos inseridos, da qual participamos cotidianamente, a escola pode criar a perspectiva de se firmar como produtora cultural. A escola pode ser um espaço de articulação dos muitos saberes que estão dispersos em nosso cotidiano, que nos chegam por inúmeros canais e suportes diferentes. Muito mais do que um espaço de transmissão de saberes acumulados historicamente, a escola pode organizar a variedade e multiplicidade de informações a que temos acesso, articulando-a a projetos de vida, de sociedade, possibilitando a criação de novos saberes, de alternativas para nossas sociedades.

Podemos pensar a escola em nossa sociedade midiática atual como local para desenvolvimento de habilidades e competências para comunicação, com múltiplas linguagens, com lógicas diferentes de produção e circulação de mensagens, utilizando todos os suportes tecnológicos existentes. Os suportes mais tradicionais como lousa, caderno, e os suportes novos, como tela de computador, tela da TV, tela de celulares e I- 
pods. A escola pode repensar o papel de seus docentes, desenvolvendo formas de trabalho não só para recepção ativa de mensagens, mas também para produção de mensagens e emissão multilíngüe, convergente, que nos situe como comunicadores, como a tecnologia atual, em seus avanços, nos permite.

Como coloca Citelli:

De certa maneira, a própria dinâmica social e de interações dos alunos com a escola vem forçando o repensar dos modelos dominantes no âmbito das praticas didáticas e pedagógicas. A forma como as linguagens de massa, a multiplicidade dos veículos e os novos códigos entraram no cotidiano social e, conseqüentemente, no universo dos jovens, trouxe consigo o fato imperioso de que o trabalho pedagógico passou a requisitar outros procedimentos conceituais e operacionais, entre eles os de uma absorção mais intensa das maneiras de se transacionar a informação e de se relacionar com linguagens ancoradas em diferentes sistemas de signos. (CITELLI, 2004: 205)

É essencial que a escola dialogue com a dimensão cultural dos sujeitos e hoje, essa dimensão cultural é perpassada também pelos meios de comunicação. A linguagem da TV, dos computadores, em especial a linguagem da rede mundial, a internet, é parte essencial da cultura contemporânea e da conformação da identidade dos indivíduos. Se a dinâmica social está perpassada por diferentes linguagens, ancoradas em diferentes sistemas de signos, estas linguagens e signos devem estar incorporados ao cotidiano das escolas, em suas práticas didáticas. A escola assume, assim, um diálogo com a cultura de seu tempo, também colaborando para que se tenha criticidade diante das produções culturais, capacidade de leitura ampla e articulada.

Alguns autores, como Silva (2011), destacam que as produções culturais têm intencionalidades, apresentando concepções de mundo, atravessando as experiências de vida cotidianas. Ao entendermos currículo como um conjunto de experiências e vivências das crianças, relacionadas a formas de aprendizagem, podemos dizer que as produções culturais contemporâneas, inclusive as produções midiáticas, compõem os currículos vivenciados por nossos alunos. Nas palavras de Silva:

Tal como a educação, as outras instâncias culturais também são pedagógicas, também tem uma "pedagogia", também ensinam alguma coisa. Tanto a educação quanto a cultura em geral estão envolvidas em processos de transformação da identidade e da subjetividade. (...) Da perspectiva da teoria curricular, poderíamos dizer que as instituições e instâncias culturais mais amplas também têm um currículo. (...) Sem ter o objetivo explícito de ensinar, entretanto é óbvio que elas ensinam 
alguma coisa, que transmitem uma variedade de formas de conhecimento (...) que são vitais na formação da identidade e da subjetividade. (SILVA, 2011:139-140)

Ao assumirmos que as produções culturais contemporâneas colaboram na construção da identidade de nossos alunos, é necessário pensarmos tempos e espaços das escolas que nos permitam o exercício da reflexão sobre essas produções, dialogando com as mesmas, criando também a partir delas, articulando informações e ideias.

Nas escolas, entendidas como espaços de criação, de debate, de diálogo com a cultura, não se deve enfatizar somente a leitura de signos verbais. Podemos enfatizar a leitura de diferentes signos, em suportes diversos, inclusive as telas portáteis que estão presentes em nosso cotidiano. Podemos realizar, a partir da escola, a leitura de múltiplos significados, conseguindo trabalhar a polissemia atual existente em nossa sociedade.

Trabalhando na perspectiva de um diálogo com a cultura contemporânea, midiática, pautada em redes de comunicação, a instituição escolar e os professores podem colaborar para emancipar os participantes dos processos de comunicação. Martín-Barbero trabalha essa ideia, quando apresenta a recepção como espaço de interação, de negociação de sentidos.

\begin{abstract}
A recepção é um espaço de interação, de negociação de sentidos, em que é preciso fortalecer a ação reflexiva das pessoas da recepção em suas próprias circulações, veiculações de sentidos sobre a vida no mundo, e em confronto com a cultura das mídias e a cultura sócio-histórica. (MARTÍN BARBERO, 1995:58)
\end{abstract}

Há que se considerar nos processos de comunicação, nas propostas e programações apresentadas pelos meios, não somente as mensagens, mas os modos de interação e de construção de significado que se estabelecem entre os usuários a partir das mensagens veiculadas. Este é um papel importante a ser trabalhado por professores: assumir-se como mediadores culturais, capazes de atuar na interação e na construção, desconstrução e reconstrução de significados veiculados pelas mídias.

Ao pensarmos em educação em novos contextos, como o contexto atual em que vivemos, um espaço privilegiado é o da formação de professores. Os professores não devem ter como maior preocupação os programas de TV ou sites aos quais os alunos estão expostos e como as mensagens podem influenciá-los, mas, sobretudo, com a maneira de ajudá-los a elaborar, a fazer mediações reflexivas, sensíveis, em relação a essas programações e às necessidades socioculturais do mundo contemporâneo. A 
preocupação maior dos professores deve ser com a incorporação responsável das novas linguagens, com o perceber aquilo que os alunos têm a manifestar sobre sua participação no mundo das múltiplas mídias, o que expressa à constituição de um novo tecido social.

A escola, nesse começo de século XXI, inserida numa sociedade midiática e perpassada por avanços tecnológicos, pode se construir cotidianamente como espaço de interação, de escuta de diversas vozes, de abertura a novas possibilidades criativas, articulando todos esses saberes na direção da construção de uma sociedade mais plural, democrática e emancipada.

Esse espaço que é a escola (...) precisa existir como um espaço de aprendizagem, de ensino e aprendizagem sistemáticos da cultura. (...) é preciso discutir como é que vamos organizar isso no currículo, como fazer esse currículo se integrar no mundo de hoje. (...) A escola enfrenta desafios enormes para conseguir ser significativa para o próprio jovem, para as próprias crianças. Ela tem que fazer diferença, em termos valorativos, em relação a outras formas de aprendizagens que existem na sociedade. (PIMENTA, 2003:178)

Uma escola como espaço de aprendizagem, espaço de criação e aberto ao diálogo com outros espaços de aprendizagem, que trabalhe na perspectiva das construções de cada indivíduo na trama coletiva, mais do que com a transmissão simplesmente dos saberes ditos como importantes. Assim, os alunos têm mais possibilidades de desenvolverem-se enquanto sujeitos reflexivos e responsáveis pela construção de seu próprio processo de conhecimento, o que inclui serem também atuantes nos processos de recepção da programação e dos conteúdos que chegam via as inúmeras telas midiáticas de seus cotidianos.

Ao trabalhar com as múltiplas linguagens e códigos apresentados nas telas do computador, da TV, dos celulares, dos cinemas, incorporando-as ao cotidiano escolar, podemos debater ideias e significados, posicionarmo-nos quanto às questões sociais, de nossa vida, quanto à nossos projetos e sonhos.

A mediação a ser exercida por professores no cotidiano escolar coloca a escola como produtora social de comunicação, entrando na rede de construção de significados onde já operam outras instâncias sociais, assumindo que também pode significar e resignificar as formas de vida, de convivência, de construções sociais que estão apresentadas a todos nós diariamente. 
Ao apontar a escola e seus professores como agentes das transformações exigidas pelo atual contexto sócio cultural, temos que nos remeter a como tem sido historicamente nossos processos de formação de professores.

A formação inicial de nossos professores contempla o debate a respeito das transformações pelas quais passa nossa sociedade? Existe uma discussão a respeito da produção social da comunicação com mídias em nossos cursos de formação docente?

Os contextos atuais que apresentamos, atravessados pelas mídias, desafiam nossas concepções tradicionais a respeito do conhecimento, dos processos de ensino aprendizagem, do papel da escola e dos professores. Se a escola precisa dialogar com outras instâncias culturais, entre elas, as mídias, os professores, como atores centrais nesse processo, necessitam pensar sobre este diálogo, estar preparados para esse trabalho.

A questão evidenciada neste momento é a seguinte: o fato de existirem novas sociabilidades, vínculos naturalizados entre o sujeito e os múltiplos suportes técnicos, teria alcançado o percurso profissional do futuro docente, ele próprio formador de outros tantos jovens, ainda mais afeitos ao circuito da comunicação generalizada? (CITELLI, 2010:20)

A dúvida apresentada por Citelli é uma questão central e nos remete ao processo de formação de professores. Os cursos de formação inicial de professores estão preparando os docentes para o cenário em que trabalharão? Os cursos têm discutido em seu cotidiano, a necessidade de um trabalho com múltiplas linguagens, numa sociedade atravessada por mídias e pelas mais diversas tecnologias?

Para pensarmos sobre estas questões, nosso próximo capítulo discute a formação de professores em relação a este cenário da sociedade contemporânea, midiática e tecnologizada. 


\title{
CAPÍTULO 2 - DOCENTES E SOCIEDADES MIDIÁTICAS: PENSANDO A FORMAÇÃO DE PROFESSORES NO CONTEXTO ATUAL
}

\begin{abstract}
Compreender os caminhos e descaminhos da prática é uma tentativa de interpretar nosso modo de ser, que não se esgota no fazer cotidiano, mas se prolonga historicamente para além dele. É aquilo que fazemos que projeta o futuro, pois é através das ações pessoais e institucionais que projetamos modos de ser e modelos para poder ser mais do que aquilo que somos.
\end{abstract}

(Ghedin, Leite e Almeida)

Para pensar a formação inicial de professores em sua relação com o momento sócio histórico que estamos vivendo em nosso país e na sociedade contemporânea, é importante que esta reflexão esteja contextualizada. Portanto, partirei da reflexão sobre a realidade vivida pelas professoras e professores em seus cotidianos, o que significa apurar as lentes por meio das quais percebo a atividade docente no Brasil atual, em especial na região em que moro e que é objeto de estudo desta pesquisa, a cidade de Santos, localizada no litoral do Estado de São Paulo.

Destaco num primeiro momento dois pontos: importante pensar em cotidianos, no plural mesmo. Não há uma única forma de construirmos nosso dia a dia, não há uma única possibilidade de construção de quem somos e das formas como agimos. Sempre há inúmeras possibilidades, inclusive quanto a nós mesmos, como pessoas e como profissionais. Não somos os mesmos todos os dias. Cada nova experiência que vivenciamos abre outras/novas perspectivas, nos permite fazer escolhas diferentes. O segundo ponto está relacionado a este: se não somos sempre os mesmos, também não há somente uma forma de ser e de constituir-se professor. Há inúmeras formas. Constituímo-nos professores por meio de inúmeras trajetórias diferentes, de vida, de processos de formação, dos locais nos quais trabalhamos. Trajetórias que se cruzam umas com as outras e que vão costurando, por sua vez, outras formas de ser docente, num processo contínuo e dialético, de interpenetração de tantas possibilidades diversas. As realidades e formas de construção do ser docente que apresento e analiso em 
seguida, são minhas percepções atuais, em função das experiências que tenho vivido inclusive em cursos de formação inicial de professores - e dos estudos e leituras que tenho feito neste trajeto de pesquisa.

\subsection{Retratos da rede municipal de ensino de Santos, retratos de professores:}

Com a intenção de contextualizar o local de realização desta pesquisa, faço um breve retrato da cidade de Santos. É uma cidade de porte médio, com aproximadamente 500 mil habitantes, localizada no litoral do Estado de São Paulo. Tem uma tradição histórica de ser, ao mesmo tempo, uma cidade conservadora, constituída pelo desenvolvimento das lavouras de café e seu escoamento pelo porto, o que a aproxima da trajetória das elites que constituíram o Brasil, ideológica e culturalmente, e também um local de resistência às imposições ou restrições impostas por governos autoritários, com participação política dos munícipes nos rumos da cidade. A economia gira em torno das atividades portuárias, do comércio e da prestação de serviços. Santos integra a região metropolitana da Baixada Santista, sendo a cidade com melhores índices educacionais da região. A cidade conta hoje com uma rede municipal de ensino com aproximadamente 70 unidades, entre escolas de ensino fundamental I, II e infantil. Tem, em média, 4000 professoras e professores trabalhando nessas escolas, em diferentes turnos: matutino, vespertino e noturno.

Trabalho nessa rede municipal de ensino há, aproximadamente, 15 anos. Boa parte desse tempo trabalhei em cursos de formação inicial, nível médio, o chamado curso de Magistério ou Escola Normal ${ }^{9}$. Para acompanhar atividades de estágio das alunas em formação inicial, visitava as várias escolas de educação infantil e ensino fundamental da rede e desenvolvia, junto às alunas, atividades nessas escolas com as crianças e adolescentes que ali estudavam. A rede municipal de Santos é uma rede que conheço de forma próxima, em seus cotidianos de trabalho, de processos de ensino aprendizagem, em suas facetas diversas de relações humanas.

\footnotetext{
${ }^{9}$ O Curso de Magistério na rede municipal de Santos foi criado como projeto experimental de formação de professores, sendo trabalhado em período integral. Vigorou até 2010, em função da legislação vigente, que determina formação em nível superior.
} 
Para os estudos desta pesquisa, visitei diversas escolas da rede municipal, em especial as escolas da chamada zona leste. ${ }^{10}$ Dialoguei com professoras e professores em seus horários de reunião pedagógica, conversei com as equipes técnicas das escolas, entrei nas escolas, nas salas de professores, caminhei pelos corredores das escolas, enfim, estive presente nos cotidianos das escolas.

Diante das observações e olhares que construí nestes tempos em que estava nas escolas da rede municipal, se pudesse apresentar um retrato da professora/professor que eu vejo hoje em atuação eu diria que, na maior parte das vezes, é uma professora/professor cansado, com pouca esperança em relação às possibilidades de transformação do seu dia a dia. Uma professora/professor que está com a alma desiludida, que perdeu o brilho no olhar que caracteriza o ser humano quando estamos fazendo algo que amamos, algo pelo que vale a pena viver, algo que nos traz sentido e significado. Professores sem entusiasmo são aqueles que parecem não vislumbrar o que podem criar, que não vêem o novo, não percebem o seu próprio potencial e o de seus alunos. Um professor que vive uma crise da sua identidade profissional, do seu saber e do seu saber fazer.

Mas este retrato que faço dos professores de Santos, não é um retrato localizado somente nessa cidade ou região. É hoje um retrato possível de ser feito no país como um todo. As condições de trabalho dos docentes, as questões salariais e de carreira, o cotidiano das salas de aula são questões que perpassam os cotidianos dos docentes das mais diversas partes do Brasil. Este cansaço do professorado frente às adversidades e realidades enfrentadas todos os dias tem sido objeto dos mais diversos estudos, que apontam para a necessidade de pensarmos o fazer docente, seus processos de formação, as condições desse fazer e dessas instâncias de formação. Estes estudos sobre o desânimo dos professores, sobre sua apatia, apresentam esse quadro como uma síndrome que atinge principalmente os profissionais, como são os professores, que são encarregados em seus trabalhos cotidianos do cuidar de outras pessoas, no caso, os alunos e alunas. Para denominar esta síndrome

Burnout foi o nome escolhido; em português, algo como 'perder o fogo', "perder a energia" ou "queimar (para fora) completamente" (numa tradução mais direta). É uma síndrome através da qual o trabalhador perde o sentido da sua relação

\footnotetext{
${ }^{10}$ A Secretaria de Educação de Santos dividiu as escolas em zoneamentos, segundo os bairros da cidade. Temos quatro zonas: leste, noroeste, morros e área continental.
} 
com o trabalho, de forma que as coisas já não o importam mais e qualquer esforço the parece ser inútil. (CODO e VASQUESMENEZES, 2006: 238)

Esta situação dos professores, este sentimento de desencanto e desilusão, de certa apatia, é também descrito por Esteve ao falar das tentativas de reforma do ensino em países europeus nos anos de 1990:

...estas reformas surgem num momento de desencanto, sendo olhadas com grande cepticismo: a sociedade parece que deixou de acreditar na educação como promessa de um futuro melhor; os professores enfrentam a sua profissão com uma atitude de desilusão e renúncia, que se foi desenvolvendo em paralelo com a degradação da sua imagem social. (ESTEVE, 1995: 95)

Portanto, o retrato que faço da rede municipal de ensino de Santos e de certa desistência do educador frente a tantos percalços vivenciados nos cotidianos, é um retrato que se pode dizer, está generalizado em todo o Brasil e também em outros lugares do mundo, lugares conectados pelos processos de globalização, em todas suas benesses, mas também em todas suas problemáticas sociais.

Esse retrato feito em relação aos educadores é um retrato que reconhece todas as dificuldades da vida diária da maioria das professoras e professores desse país: não ganham bons salários, compatíveis com as necessidades da vida humana; tem duas ou três jornadas de trabalho e sendo a grande parte mulheres, outra jornada em casa, com serviços domésticos; são professoras e professores expropriados dos seus saberes e fazeres; trabalham em escolas, em sua maioria, com infra estrutura péssima; são professoras e professores numa sociedade que vive uma crise de valores, onde respeito, solidariedade, ética, parecem desaparecer de nossas atitudes cotidianas.

Ao pensarmos sobre a realidade e as condições de trabalho vividas pelos educadores torna-se evidente que um mundo globalizado e complexo como o nosso traz demandas de trabalho igualmente complexas.

Para dar conta delas é necessário que os profissionais da escola tenham um elevado nível de qualificação e, evidentemente, recebam uma remuneração correspondente à importância da sua atuação e contem com condições adequadas para realizar o seu trabalho (...) é necessário um processo que ressignifique a condição docente, promovendo a melhora do estatuto profissional e das condições de vida e trabalho dos professores, sem o qual fica difícil a concretização de uma mudança da 
escola e da qualidade das aprendizagens aí vividas pelos estudantes. (ALMEIDA, 2004:107-108)

Com demandas mais complexas, há uma real necessidade de que todos os processos dêem conta dessas demandas, desde a formação dos docentes, até a infra-estrutura colocada a disposição para os trabalhos a serem desenvolvidos, passando pelas questões salariais. Dados citados por AGUIAR (2004) apresentam um retrato recorrente em escolas da rede pública: a falta de recursos existentes, inclusive se comparadas com as escolas da rede privada:

Estudos têm demonstrado a importância das condições materiais das escolas para o desenvolvimento de atividades que favoreçam uma aprendizagem satisfatória. Todavia, tais condições ainda apresentam sérias limitações, inclusive com significativas diferenças entre a rede pública e a rede privada, como pode ser observado no Censo Escolar de 2002: nas escolas com classes de 1 a 4 série do Ensino fundamental, em todo o Brasil, apenas $19,5 \%$ possuem bibliotecas, enquanto nas escolas privadas chega a $79 \%$. Das escolas privadas, $56 \%$ têm laboratório de informática e na rede pública somente $4,8 \%$ delas. (AGUIAR, 2004: 132)

Ou seja, embora se exija cada vez mais do trabalho do professor, cada vez se exija maior diversificação de metodologias, cada vez se exija mais habilidades, diante das novas demandas sociais, estas exigências nem sempre são acompanhadas por uma infra-estrutura que colabore para o bom andamento dos trabalhos e nem por cursos de formação continuada que permitam um maior desenvolvimento dos professores quanto a sua profissionalidade e as exigências que lhes são feitas, tanto pelos governos como pela própria sociedade civil.

Nas palavras de Batista e Codo:

A expansão do ensino público aconteceu sem cuidado com a qualidade da infra-estrutura das escolas. Edifícios com condições ruins, carência às vezes de materiais básicos de funcionamento da escola, ausência bem mais acentuada de recursos de apoio ao ensino e de recursos que promovem melhores condições de trabalho, etc. (BATISTA e CODO, 2006: 71)

Ao fazermos um retrato do educador hoje, este retrato só pode ser feito se retratarmos também os tempos e espaços onde estão inseridos os educadores. Ou seja, a um retrato do educador, corresponde também um retrato da escola brasileira, em suas reais condições de trabalho cotidianas, em face das demandas sociais que temos hoje, nas sociedades contemporâneas, inclusive considerando as reflexões apontadas neste 
trabalho, quais sejam, estarmos inseridos em sociedades midiáticas, com configurações sociais diferentes das tradicionais configurações a que estávamos todos acostumados e adaptados, inclusive professores e alunos. Pensar a formação docente, passando pelas percepções diante de como estão os professores e qual a situação das escolas e da educação, exige um pensar enraizado, refletido a partir das condições reais de trabalho e de construção da identidade profissional docente nestas condições reais.

As novas demandas sociais trazem novas demandas para a formação de docentes, para a constituição da identidade social dos professores. Os conhecimentos exigidos dos professores estão relacionados com a formação desta identidade, em como, de que formas, o professor será exigido socialmente, será considerado competente profissionalmente falando. As novas demandas sociais contemporâneas também estão relacionadas à crise que percebemos nos educadores hoje:

A crise de identidade do educador é também o resultado singelo do fato que ele, atualmente, não tem segurança a respeito do que deve saber e ensinar e de como deve ensinar. Um problema central é a formação do educador, ou seja, o processo por meio do qual ele se apropria do saber e do saber-fazer, e que significa seu ingresso na "confraria". (BATISTA e CODO, 2006: 71)

Nesta pesquisa, que tem como objeto de estudo, as articulações entre formação de professores e aspectos educacionais de uma sociedade midiática, percebe-se esta crise de identidade do professor quanto a seus saberes e fazeres. Destaco, como já colocado antes, que este não é um retrato somente da região da Baixada Santista, mas um retrato da escola brasileira e de seus professores, um retrato relacionado a nossa atual situação sócio cultural, no Brasil e no mundo, em que estamos ressignificando também estes saberes e fazeres docentes, em função de novas realidades e exigências sociais que estamos todos experienciando.

Diante deste quadro, diante deste retrato breve de como estão os professores em seus cotidianos, penso algumas questões que se fazem importantes para refletirmos sobre a formação de docentes: como nos construímos professoras e professores? Como chegamos à situação atual dos nossos processos formativos? Como pensar novos/outros caminhos para a formação, que contribua para trazer de volta nosso entusiasmo diante do ato de ensinar e aprender? Como pensar a formação docente nessa sociedade contemporânea, com outra configuração social, inclusive a configuração criada também pelas mídias e impactos tecnológicos em desenvolvimento acelerado? 
Para pensar um pouco sobre estas questões, discuto em seguida, aspectos da legislação educacional que trata da formação dos docentes e questões centrais dos processos de formação dos professores analisadas por estudiosos desse campo. Ao final, discuto como as instituições formadoras de professores apresentam seus quadros curriculares inseridos em seus projetos pedagógicos, para pensarmos sobre as propostas de formação e as novas demandas sociais, em especial as relacionadas a processos educomunicacionais.

\title{
2.2 Pensando a legislação de formação inicial de professores:
}

\begin{abstract}
Ao certo, não se sabe como preparar hoje os educadores, não se sabe qual seria o papel da educação e da instituição escolar numa situação como a atual, caracterizada pela reestruturação do sistema capitalista e as brutais metamorfoses que acarreta (a outra face da modernização). As certezas tradicionais parecem se "desmanchar no ar." (Batista e Codo)
\end{abstract}

Em primeiro lugar cabe destacar que pensar educação e, em especial, a docência é sempre pensá-las inseridas num contexto histórico e social, permeadas por questões econômicas, políticas, culturais e sociais. Os processos educacionais e, dentre eles, a docência, são uma construção histórico-social, onde não se pode perceber a educação de forma isolada, mas sempre contextualizá-la temporal e espacialmente, percebendo a dialeticidade das relações, em processos sócio-históricos que se interpenetram, articulando-se e compondo-se continuamente.

O Brasil vive hoje, como país, em seu contexto sócio-historico, um processo de transformação em diversos níveis e setores. Este processo de mudança influencia e é influenciado também pelas demandas educacionais. Uma dessas demandas educacionais é referente à ampliação do acesso a escolarização em diversos níveis, desde a escolarização básica até o ensino superior, com ensino de qualidade, que nos ajude a construir uma sociedade mais inclusiva e com capacidade de tornar sustentável seu desenvolvimento.

Em função dessas demandas educacionais, tivemos diversos debates e a construção de alguns documentos nos últimos anos, tratando dessas demandas. Em 
2001, tivemos a promulgação, pelo Ministério da Educação - MEC - do Plano Nacional de Educação - PNE, com vigência de dez anos, onde Estados, Distrito Federal e municípios deverão, com base nesse plano, elaborar planos decenais correspondentes. Os objetivos do Plano, de forma sintética, são: elevação global do nível de escolaridade da população, melhoria da qualidade de ensino, redução das desigualdades sociais no que diz respeito ao acesso e permanência, com sucesso, na educação pública e democratização do processo de gestão. (BRASIL/PNE, 2001)

Outro documento que aponta para a busca de transformação no cenário educacional do país é o Plano de Metas Compromisso Todos pela Educação, promulgado em 2007, onde o governo federal, em colaboração com os Estados, o Distrito federal e os municípios, envolvendo as famílias e as comunidades, busca a mobilização social pela melhoria da qualidade da educação básica, por meio de programas e ações de assistência técnica e financeira.

Esses documentos têm favorecido no país, uma maior discussão sobre a importância da educação para a reflexão e encaminhamento de questões sócio políticas e a construção de uma sociedade mais igualitária e sustentável em seu desenvolvimento, com envolvimento também da sociedade civil e de entidades de classe, inclusive das universidades públicas e privadas e dos professores que nelas trabalham.

Entre outras questões também tem se discutido a formação de quadros profissionais para o país, inclusive os quadros relativos ao trabalho nas áreas de educação escolar. Em 1996, com a promulgação da Lei de Diretrizes e Bases da Educação Nacional - LDB 9394/96 - a discussão trouxe à tona, entre outros elementos, a formação em nível superior dos profissionais da educação, como uma das formas de possibilitar melhoras nos processos de ensino-aprendizagem.

Portanto, nos últimos anos, o Brasil tem vivido um período de debates e mudanças também em seu processo de formação de professores, alinhando a perspectiva da formação dos docentes às mudanças que se fazem necessárias para uma educação com mais qualidade e mais inclusiva no país, garantindo o acesso a e a permanência das crianças na escola. Essas mudanças estão expressas também no que tange a legislação 
em vigor no país. As discussões e encaminhamentos para a construção dessas leis envolveram órgãos de classe, universidades, governo e sociedade civil.

Procuro, neste item deste capítulo, fazer uma apresentação sobre a legislação que norteia a formação inicial de professores no país atualmente e depois fazer um recorte dessa legislação quanto ao aspecto especifico desse trabalho: a relação entre a formação de professores e o trabalho docente com mídias.

\subsubsection{As normas legais para formação de professores}

A formação inicial de professores é tratada em diversos documentos, que norteiam as políticas públicas para essa formação. Entre outros documentos, são estabelecidas normas para a formação docente na Lei de Diretrizes e Bases, em Resoluções e Pareceres do Ministério da Educação, em sua Câmara da Educação Superior e nas Diretrizes Curriculares Nacionais para o curso de graduação em Pedagogia. Destacaremos aspectos desses documentos relativos à formação inicial de professores.

A Lei de Diretrizes e Bases da Educação Nacional - Lei no. 9394/96 - trata da formação de professores para a educação básica no artigo no. 61 até o artigo no. 67, que compõem o título VI da LDB - Dos profissionais da educação.

Destacarei alguns pontos destes artigos, que podem nos ajudar a refletir sobre a formação de professores como está pensada e proposta no país hoje e que é uma das formas pelas quais nos constituímos cotidianamente enquanto professoras e professores.

Segundo o artigo 61 da LDB, a formação de professores deverá ter alguns fundamentos: articulação entre teoria e prática, uma sólida formação básica, com conhecimento de fundamentos científicos e sociais que sejam inerentes as suas atividades. O artigo também cita o aproveitamento da formação já existente e experiências anteriores.

Entre outras interpretações, alguns autores destacam que:

...a LDB buscou, por meio desse pressuposto, acolher a idéia da importância e da complexidade do processo de formação de professores e promover mudanças no quadro da formação 
docente para a Educação Básica do país. (GHEDIN, LEITE e ALMEIDA, 2008:39)

Diante da complexidade do processo de formação e das próprias demandas sociais há necessidade de um preparo mais consistente e articulado à questões fundamentais da sociedade.

Este preparo mais consistente dos profissionais da educação tem destaque no artigo 62, onde se aponta que a formação dos docentes será em nível superior, em universidades ou institutos superiores de educação, admitindo-se como formação mínima a oferecida em cursos de nível médio, na modalidade normal.

Este artigo da LDB provocou movimento em vários locais do país, onde a busca pela formação em nível superior intensificou-se, inclusive patrocinada por governos municipais. Este foi, por exemplo, o caso da rede pública municipal de Santos, onde em 2003 se encaminharam todos os professores em serviço que não tinham formação superior para cursos de Pedagogia, por meio de parceria entre uma instituição educacional formadora da cidade e a prefeitura municipal. Portanto, estamos nos constituindo como professores, nos últimos anos, também pautados por uma legislação que tende a colocar parâmetros mais focados no processo de formação, exigindo mais preparo dos profissionais, em função de novas demandas sociais. Cabe pensar se essa exigência maior na legislação vem sendo acompanhada de investimentos reais que melhorem a formação, tanto a inicial quanto a continuada. Também cabe refletir sobre as políticas de remuneração dos docentes e os investimentos na infra-estrutura das escolas, para que as exigências quanto à melhora dos processos de formação docente não estejam somente no nível da legislação, sem os desdobramentos necessários para que se efetivem e possam dar conta das demandas educacionais e sociais do país, num mundo globalizado e cada vez mais conectado e interdependente, como é o nosso.

O artigo 63 da LDB aborda a questão institucional da formação de professores ao destacar o papel dos Institutos Superiores de Educação, que deverão manter os cursos formadores para os profissionais da educação básica, os programas de formação pedagógica para aqueles que já são portadores de diplomas de formação superior e manter programas de formação continuada para os profissionais da educação. Uma questão fundamental que aparece neste artigo é a apresentação dos institutos superiores de educação como lócus para formação de professores, se esta não acontecer nas universidades. 
Há um destaque para a questão curricular da formação inicial de professores, quanto à inserção de horas de prática de ensino no computo do quadro curricular, reforçando a ideia da articulação entre teoria e prática.

A questão da valorização profissional tem destaque no artigo 67, inclusive com ênfase na experiência docente como pré-requisito para o exercício profissional de quaisquer outras funções de magistério, tais como as funções ligadas ao planejamento, orientação e direção da organização escolar.

Os artigos inseridos neste título VI da LDB - Dos profissionais da educação nos fazem perceber a importância do debate sobre a formação de professores no país, que transparece também nos instrumentos legais. Partindo das referências apresentadas na Lei de Diretrizes e Bases da Educação Nacional, foram regulamentadas algumas políticas públicas de formação inicial de professores.

A década inicial de 2000 apresentou vários desses documentos.

Entre eles, foram instituídas diretrizes nacionais para formação de docentes:

Em 2002 instituíram-se as Diretrizes Curriculares Nacionais para a Formação de Professores para a educação Básica, cuja redação centra-se no desenvolvimento de competências pessoais, sociais e profissionais dos professores. Postulam essas diretrizes que a formação de professores que atuarão nos diferentes níveis e modalidades da educação básica observará alguns princípios norteadores desse preparo para o exercício profissional especifico, que considerem, de um lado, a formação de competências necessárias a atuação profissional, como foco do curso, a coerência entre a formação oferecida e a prática esperada do futuro professor, e de outro, a pesquisa, com foco no ensino e na aprendizagem, para compreensão do processo de construção do conhecimento. (GATTI e BARRETO, 2009: 46)

Segundo esse documento, a formação de professores deveria ter como um de seus focos a aprendizagem de estratégias didáticas, pelos futuros professores, que ajudassem os alunos na resolução de situações problema. Apresenta também alguns eixos que devem nortear a composição dos projetos pedagógicos formadores de cada instituição. Entre esses eixos, destaca- se o desenvolvimento de processos de interação e de comunicação, com ênfase na construção e desenvolvimento da autonomia intelectual e profissional.

Ressalte-se que alguns autores, como GATTI e BARRETO (2009) apontam o hiato existente em diversos cursos de formação inicial de professores entre o que está posto na legislação e nos projetos pedagógicos das instituições formadoras e o que realmente acontece no cotidiano curricular, no cotidiano das escolas e das aulas. 
Embora existam avanços no país quanto ao debate sobre as políticas públicas para formação de professores, ainda se exige um aprofundamento destas questões, na busca de maior articulação entre o que se pensa para a formação, o que está apresentado nas legislações e como estas resoluções chegam ao cotidiano dos cursos de formação inicial dos docentes.

Ghedin, Leite e Almeida apresentam como um avanço a formação de professores em contextos específicos:

Sem dúvida, a possibilidade de oferecer a formação de professores em cursos específicos, do primeiro ao último ano, através de projetos pedagógicos próprios, comparece como um dos principais ganhos obtidos pela reforma na formação de professores, condição relevante e essencial para concretizar a profissionalização do professor, podendo assegurar desta forma, a construção dos saberes docentes necessários. (GHEDIN, LEITE e ALMEIDA, 2008:40)

Sendo assim, podemos pensar que professoras e professores estão constituindose profissionais num contexto de mudanças e reformas no processo de formação de professores, que buscam dar conta de novas demandas sociais e educacionais, conectadas ao momento sócio histórico que vivemos.

A preocupação com a formação da identidade do professor como educador transparece em vários documentos, como no Parecer CNF/CP28/2001. Há uma compreensão de que os professores devem ser formados para que compreendam o ambiente educacional de forma geral e também o contexto específico da escola.

Uma vez que estamos analisando de que maneiras a formação inicial de professores contribui para a construção de uma identidade profissional, um jeito de ser professor, importante ressaltar que estamos apontando reformas que se iniciam com maior força no final da década de 80 e nos anos 90 em diante. Portanto, muitos dos professores que estão hoje trabalhando nas escolas, foram formados em época anterior a esses processos de reforma. Foram formados com cursos estruturados de formas diferentes das atuais. Ghedin, Leite e Almeida (2008) fazem considerações quanto ao estágio, que nos revelam nuances dos processos de formação tradicional dos docentes:

De um modo geral, os estágios foram sempre considerados como aspectos irrelevantes na formação docente na maioria dos cursos de formação de professor. Não houve muita preocupação em oferecer uma organização curricular e pedagógica integrada e articulada, na qual a teoria organizasse as percepções para a prática e esta pudesse reorganizar e ressignificar a teoria. (GHEDIN, LEITE e ALMEIDA, 2008: 44) 
As Diretrizes Curriculares Nacionais para o curso de Pedagogia apontam claramente que os estudantes devem trabalhar um amplo repertório de informações e habilidades, que possibilite uma formação pautada nos princípios da interdisciplinaridade, da democratização, da relevância social dos conhecimentos, da importância da ética e de uma sensibilidade afetiva e estética diante do mundo no qual estão inseridos.

Conforme apontado no parágrafo único do artigo $3^{\circ}$.

Para a formação do licenciado em Pedagogia é central: I - o conhecimento da escola como organização complexa que tem a função de promover a educação para e na cidadania; II - a pesquisa, a análise e a aplicação dos resultados de investigações de interesse da área educacional; III - a participação na gestão de processos educativos e na organização e funcionamento de sistemas e instituições de ensino. (BRASIL, 2006:1)

As Diretrizes para os cursos de Pedagogia evidenciam a formação do estudante tendo como base identitária a docência, articulando esta docência a processos de pesquisa e investigação e a gestão dos processos educativos. Aponta-se um caminho de articulação entre teoria e prática, de busca de superação de um modelo de formação pautado em fragmentação de conhecimentos e em divisão de tarefas no ambiente escolar.

A preocupação em trabalhar na formação inicial com aspectos ligados a práticas dos professores deve favorecer a construção de saberes docentes necessários a realidade das escolas atuais, inseridas em sociedades midiáticas, globalizadas, com processos de mundialização de cultura, dentre outros fatores. Enfim, escolas que estão inseridas e são partícipes nas sociedades contemporâneas, com algumas exigências específicas deste nosso tempo.

Entre outras exigências colocadas pelas sociedades contemporâneas, existem aquelas apresentadas na interface entre processos comunicacionais e processos educacionais, como coloca Citelli:

Ao predicarmos os diálogos entre comunicação e educação, estamos tratando, portanto, não de acomodar modismos ou aceitar os tão insistentes apelos de ajuste instrumental do capital escolar à razão produtiva matizadora do nosso tempo, mas de uma relação crítica entre os vários núcleos produtores de sentidos visando a tornar aparente aquilo que já está latente nas salas de aula: uma cultura em cujo interior podem ser lidas as marcas da ampla reorientação nos modos de ver, sentir, 
conhecer e saber que singularizam os processos formadores no mundo contemporâneo. (CITELLI, 2004: 241)

Ao admitirmos mudanças culturais que nos trazem novas formas de ver, sentir, conhecer e saber e admitir também que os professores precisam estar formados com saberes docentes necessários a realidade das escolas atuais, fica evidente que também os processos de formação inicial de professores devem estar atentos a essas novas necessidades/realidades e novas formas de conhecer que se colocam em função das próprias transformações culturais nas sociedades em que vivemos. Nas palavras de Franco:

Considero que os processos de formação precisam considerar a estruturação de uma experiência formativa, experiência essa que não apenas mostra a prática; transmite teorias; discursa sobre a profissionalização; essa experiência precisa colocar o sujeito em processo de diálogos com a realidade; diálogos formativos com sua própria identidade, diálogos que irão formar capacidades de reelaboração reflexiva, a partir das contradições da existência vivenciada. (FRANCO, 2006; 13)

Processos formativos que levem em consideração as transformações vivenciadas nas sociedades midiáticas, onde as produções culturais estão perpassadas por novas linguagens, ancoradas em diferentes suportes. Processos formativos que colaborem para que os futuros professores possam mediar às interfaces entre processos educacionais escolares e processos comunicacionais com mídias, dialogando com a cultura simbólica da contemporaneidade, de forma crítica e reflexiva.

\subsection{A legislação de formação de professores e a relação entre educação e comunicação:}

A legislação de formação de professores também aponta alguns aspectos diretamente ligados às questões entre educação e comunicação, ao evidenciar as exigências sociais atuais e como os processos formativos devem dar conta destas demandas.

O Parecer CNE/CP no. 9/2001 destaca a necessidade de inserção nos cursos de formação de professores em nível superior as TIC - tecnologias de informação e 
comunicação-, devido ao impacto que as tecnologias têm apresentado para o tecido social.

No corpo da justificativa deste Parecer tem-se a seguinte argumentação:

A democratização do acesso e a melhoria da qualidade da educação básica vêm acontecendo num contexto marcado pela redemocratização do país e por profundas mudanças nas expectativas e demandas educacionais da sociedade brasileira. $\mathrm{O}$ avanço e a disseminação das tecnologias da informação e da comunicação está impactando as formas de convivência social, de organização do trabalho e do exercício da cidadania. (BRASIL/CNE, 2001:3)

Admite-se o impacto das novas tecnologias tanto nas formas de convivência social, quanto na organização do trabalho e nas formas de ser cidadão, questões diretamente vinculadas ao universo educacional e escolar.

Na Resolução CNE/CP 1/2006, que institui as Diretrizes Curriculares Nacionais para os cursos de graduação em Pedagogia, em seu $5^{\circ}$. artigo, onde se destaca a que o profissional formado em Pedagogia deverá estar apto para exercer suas atividades docentes, no item sétimo está relatado:

Relacionar as linguagens dos meios de comunicação à educação, nos processos didático-pedagógicos, demonstrando domínio das tecnologias de informação e comunicação adequadas ao desenvolvimento de aprendizagens significativas. (BRASIL. MEC/CNE, 2006:2)

Pode-se perceber claramente nos diferentes documentos referentes à formação inicial de professores o destaque para a relação entre aspectos ligados aos meios de comunicação e aspectos vinculados aos processos de ensino-aprendizagem, apontando a necessidade de preparar o docente para o domínio das diferentes tecnologias e suas múltiplas linguagens, em suas interfaces com os processos educacionais e escolares.

Segundo Gonçalves e Nunes,

Nesses documentos, fica evidente a utilização das tecnologias como fator essencial na sociedade contemporânea, levando-nos ao questionamento acerca das reais condições de utilização das TIC, nas escolas públicas brasileiras, e quanto à formação dos docentes para exercer tal tarefa, de modo a integrá-las aos conteúdos, construindo conhecimentos. (GONÇALVES e NUNES, 2006:6) 
Ainda que os documentos que norteiam as políticas de formação inicial de professores dêem destaque para a formação dos docentes também no que tange aos aparatos tecnológicos midiáticos comunicacionais, esse ainda é um ponto crucial em nossos currículos e práticas pedagógicas nos cursos de licenciatura.

Pesquisadores que trabalham com questões relativas à inserção das questões comunicacionais midiáticas na formação docente (NUNES, 2006; GONÇALVES, 2006; PACHECO, 1995) trabalham com a ideia que a construção dos saberes docentes está ligada as suas aprendizagens, tanto na educação formal, quanto também nos espaços não formais de aprendizagem. Ou seja, para que o professor desenvolva algumas habilidades para trabalhar com tecnologia, essas habilidades estarão ligadas também a seus processos formativos e a suas experiências, tanto nos cursos de formação inicial como em outros espaços de formação. Se os professores não desenvolvem essas habilidades em seus cursos de formação inicial, terão que desenvolvê-las em outros momentos, para poderem dar conta das atividades pedagógicas exigidas pelas demandas sociais e culturais das sociedades midiáticas atuais.

Conforme apontado no Parecer CNE/CP 9/2001: “são raras as iniciativas no sentido de garantir que o futuro professor aprenda a usar no exercício da docência, computador, rádio, vídeo-cassete, gravador, calculadora, internet e a lidar com programas e softwares educativos”. (BRASIL, 2001:24)

As escolas, as universidades, os cursos de formação de formadores e também os cursos de formação de comunicadores e educomunicadores, podem ser locais privilegiados para que experimentemos todas as possibilidades técnicas dos aparatos tecnológicos midiáticos comunicacionais, para que experimentemos todas as interfaces com os processos culturais e educacionais, as interfaces com novas formas de ler e expressar o mundo e as relações humanas trazidas por esses mesmos aparatos tecnológicos. Pensar a legislação relativa à formação docente nos obriga a repensá-la diante das cirscuntâncias atuais, face às mudanças sociais aceleradas que vivenciamos hoje. Nas palavras de Esteve: "as atitudes dos professores (...) dependem, em boa medida, do tipo de formação inicial que os professores receberam e da sua preparação prática para enfrentar os problemas reais do ensino”. (ESTEVE, 1995:109)

Além do que está colocado na legislação referente à formação inicial dos docentes, alguns outros pontos merecem destaque nestes processos de formação, nas 
formas em como nos constituímos professoras e professores, e são abordados por especialistas e pesquisadores da área.

\title{
2.4 Os processos de formação de professores e a constituição da identidade docente:
}

\begin{abstract}
Chegou o tempo de fazermos uma verdadeira revolução na formação de professores. $\mathrm{O}$ que existe é frágil. A interligação entre as questões do ensino, da investigação e das práticas escolares e a participação efetiva dos profissionais na formação dos futuros professores são fundamentais para que se crie um novo modelo de formação de professores. Não nascemos professores. Tornamo-nos professores por meio de um processo de formação e de aprendizagem na profissão. (Antonio Nóvoa)
\end{abstract}

Ao falar de formação de professores, muitos trabalhos e estudos, nos últimos anos, (GUIMARÃES, 2004; PIMENTA, 2002; DINIZ, 2006, NÓVOA, 1995; TORRES, 1998) apresentam problemas, situações complexas quanto aos processos de formação, envolvendo desde as concepções formativas, as práticas exercidas nos cursos de formação inicial, a insuficiência das políticas públicas, entre outros dados.

As produções acadêmicas e científicas vêm procurando trabalhar na dimensão dos processos formativos, para entendê-los e criar possíveis intervenções, no sentido de buscar transformações, mudanças que nos ajudem a perceber outros caminhos possíveis para a formação de professores nas sociedades contemporâneas.

Entre diversas questões ligadas à formação de professores tem se discutido a formação e sua relação com os processos de mudanças das sociedades, a falta de condições materiais do trabalho docente, a relação entre as práticas formativas nos cursos de formação e como se dá a constituição do ser docente, a especificidade de saberes docentes a serem trabalhados nos processos de formação. Apresentaremos algumas reflexões dos estudiosos dessa área nessas dimensões, para pensarmos em como nos constituímos docentes segundo essas mesmas reflexões. Relembrando que nos interessa, neste trabalho, não o aprofundamento destas questões, mas sua interface com as questões da prática docente que vem sendo exercida nas escolas em sua relação com as mudanças sociais que nos apresenta uma sociedade midiática exigindo novas reflexões e posicionamentos das práticas pedagógicas cotidianas. Práticas docentes que 
estejam voltadas para processos de ensino aprendizagem focados nos alunos atuais, em como trabalhar com esses alunos, também frutos de transformações no tecido social e que pretendemos que possam ter práticas cidadãs, de responsabilidade com a sociedade em que vivem, capazes de atitudes éticas, fraternas e justas.

Uma das facetas das produções e reflexões sobre formação de professores está ligada aos processos formativos e como esses processos trabalham os saberes profissionais, como estão as práticas formativas nos cursos de formação docente, em quais condições este processo de formação inicial acontece. GUIMARÃES (2004) nos aponta que ao pensarmos sobre as práticas formativas e os saberes profissionais veiculados nos cursos de formação inicial, podemos identificar qual identidade profissional se busca desenvolver nesses cursos.

Este é um eixo, portanto, da forma de pensarmos hoje os processos formativos: nos tornamos professores por meio de nossos processos formativos, do que eles nos apresentam no percurso da formação, do que vivenciamos nessa trajetória, quais interfaces entramos em contato, como essas interfaces conversam com nossos outros saberes e experiências. Continuamos nos formando professores, ao longo de nossa própria trajetória profissional, ao longo do que aprendemos no cotidiano de nossas escolas, de nossos cursos de formação continuada, de nossos diálogos com os outros professores, com os demais profissionais da educação com os quais convivemos todos os dias em nossas redes de saberes e fazeres. Criamos uma identidade profissional ao longo de nossos processos formativos.

Ao analisarmos alguns aspectos dos processos de formação inicial de professores vemos prevalecer uma formação mais teórica do que prática, um privilégio maior para os professores ligados diretamente a pesquisa com menor valorização dos que trabalham a docência, desvalorização de práticas profissionais, trabalho fragmentado. Nas palavras de Libâneo

os docentes universitários não modificam seu trabalho pedagógico em função das licenciaturas, raramente um professor do bacharelado interessa-se pela transposição didática do que esta ensinando, há um notório desprezo pelas formas de instrumentalização didática dos licenciandos, nega-se a necessidade de saberes específicos para a docência. (LIBÂNEO, 2004: 12-13)

Nossas práticas formativas precisam se aproximar dessa instrumentalização didática dos professores, de discutir os saberes necessários e específicos para a 
docência, permitindo que no próprio processo de formação inicial possa ir se constituindo um jeito de ser professor, de lidar com os conhecimentos e como mediá-los junto aos alunos, num processo de construção autônoma.

Temos um desafio nos processos formativos, na constituição da profissão e dos processos de profissionalização do professor, que é pensar esses processos na sociedade atual, em como termos uma formação docente bem fundamentada e que possa dialogar, de forma flexível, criativa, com a demanda de formar novas gerações que vivem numa sociedade onde as informações e conhecimentos são produzidos de forma cada vez mais acelerada, numa sociedade onde as relações pessoais e sociais, relações de trabalho e de produtividade estão em processos de transformação, conectadas às transformações tecnológicas cada dia mais velozes, tão representativas das sociedades contemporâneas.

A discussão sobre as práticas formativas dos cursos de formação inicial de professores, envolve os meios que são utilizados para essas práticas, quais saberes profissionais são veiculados e pensar também uma cultura profissional existente nesses cursos. Constituímo-nos professores também por meio das representações sobre a profissão às quais temos acesso, representações estas que estão presentes na cultura profissional trabalhada em nossos processos formativos e na sociedade na qual estamos inseridos.

Ao pensarmos neste aspecto - práticas formativas - de nossa constituição como professores, podemos fazer uma interface com as questões de como estão pensadas as relações entre as questões comunicacionais e educacionais em algumas de nossas praticas pedagógicas nos cursos de formação inicial. Nas palavras de Citelli

O sujeito-educador, saído de um instituto superior ou de algum curso para o magistério que se resumiu a prepará-lo para o trabalho com o texto verbal, está, agora, diante de uma nova rede discursiva e de desafios práticos que lhe sugerem problemas com os quais não está em condições de operar. (CITELLI, 2004: 222)

Nossas práticas formativas nos cursos de formação inicial precisam estar relacionadas com os desafios que serão vividos pelos futuros professores em seus cotidianos, com os saberes que serão exigidos pela sua atividade docente. Processos de formação que não somente coloquem os formandos em contato com a prática, mas que favoreçam o trabalho reflexivo com os confrontos suscitados por essa mesma prática (Franco, 2006). Cursos com práticas formativas capazes de preparar futuros docentes que façam a mediação entre os alunos e o campo cultural em que estão imersos, práticas 
que envolvam processos relacionais entre professor e alunos, dos alunos entre si, e destes com a comunidade na qual estão inseridos. Importante destacar ainda que as práticas formativas, enquanto práticas educativas, acontecem na intersecção de diferentes contextos, como nos coloca Sacristán (1995). Ao assumirmos a multirreferencialidade como uma epistemologia, que nos coloca a complexidade e a totalidade como categorias de análise das realidades, não podemos falar das práticas de formação fora da compreensão da dialeticidade que também as perpassa. As práticas de formação estão relacionadas a uma multiplicidade de contextos: o sistema social nas quais estão inseridas, os diferentes sistemas educativos, as múltiplas realidades das escolas e das aulas, com a atuação de diferentes sujeitos sociais. Ou seja, as práticas educativas articulam-se com contextos extra-escolares, exigindo uma compreensão ampliada dos processos de formação de docentes, onde os professores devem finalizar sua formação inicial tendo clara a questão da dialética, dos conflitos, da multideterminação do seu ser professor, com competência para utilizar os conhecimentos e experiências para seu desenvolvimento em contextos pedagógicos práticos.

Frente à existência de práticas de formação de professores centradas num processo de transmissão de conhecimento e na transmissão de saberes disciplinares (DEMO, 1990), em confronto com uma cultura contemporânea que apresenta novas formas de discurso, para além de textos verbais, necessário atentar para como trabalharmos com esse paradoxo existente hoje em algumas de nossas práticas, onde não dialogamos com um campo cultural emergente, que nos apresenta novos desafios e pensarmos outras possibilidades de trabalho com o conhecimento, numa sociedade tecnológica e informacional, em nossas escolas e universidades.

Formamos o profissional professor em nossos cursos de formação inicial, com atitudes e atividades cotidianas que dão a base para seu processo de profissionalização. Sem desconsiderar outros aspectos, importantes para a profissionalização do professor, sem duvida um dos lócus básicos para a constituição do ser docente são os cursos de formação inicial.

Portanto, estamos destacando, segundo estudos da área, este ponto: a formação inicial dos professores, no que tange as práticas formativas trabalhadas nesse processo de formação, é ponto crucial na constituição da identidade do ser professor. 
Outra dimensão que transparece nas reflexões teóricas sobre formação de professores é a dimensão da especificidade dos saberes docentes.

O professor, durante a sua formação inicial ou continuada, precisa compreender o próprio processo de construção e produção do conhecimento escolar, entender as diferenças e semelhanças dos processos de produção do saber científico e do saber escolar, conhecer as características da cultura escolar, saber a historia da ciência e a história do ensino da ciência com que trabalha e em que pontos elas se relacionam. (DINIZ, 2006:47)

Existem saberes docentes específicos que são exigidos pela profissão. Estes saberes específicos necessitam ser trabalhados nos cursos de formação inicial, fazendo parte da constituição do ser docente dos futuros profissionais. Há um imaginário social, reproduzido em muitos discursos, que afirma que o domínio de conteúdo já é suficiente para que alguém se torne professor. Essa é somente uma faceta do trabalho docente. Para alem do domínio dos conteúdos, há necessidade de desenvolver algumas habilidades quanto às formas de mediar esse conteúdo, de relacioná-lo com a vida dos alunos, com as questões sociais. Há toda uma construção de práticas pedagógicas necessárias para que o processo de ensino aprendizagem se efetive. Ou seja, nossos cursos de formação inicial são um tempo e espaço para a construção de saberes específicos para o exercício da docência. Construímo-nos professores também ao entrarmos em contato com esses saberes, ao refletir sobre os mesmos, ao incorporá-los e transformá-los em relação com nossos outros saberes e experiências.

Nas palavras de Pimenta:

O professor precisa ser formado. Ele precisa ser formado e estar em constante formação, seja num curso, seja durante seu processo de trabalho, porque a sala de aula e a escola colocamlhe questões para as quais ele não tem resposta pronta (...). A formação do professor requer investimento pessoal, institucional, público, político e social. Todos são fundamentais para a constituição do que denomino identidade epistemológica do professor (...) essa identidade se dá pela experiência, ou seja, ser professor é uma profissão que exige uma série de requisitos, o que faz crer que não é qualquer um que pode ser professor. (PIMENTA, 2002: 15)

Essa especificidade de saberes que são exigidos pela docência deve ser um ponto crucial nos processos de formação. Só poderemos efetivamente melhorar a realidade das escolas, se melhorarmos a formação dos professores e as possibilidades de desenvolvimento profissional deles. Logicamente, sem desconsiderar que é necessário 
que também existam melhoras nas condições de trabalho e nas condições salariais, compatíveis com a importância do trabalho docente para a sociedade.

Admitir que existam saberes específicos para a docência, nos faz também pensar na contextualização desses saberes. São saberes que estão relacionados ao mundo em que vivemos, a sociedade em que estabelecemos nossas relações, nossas formas de trabalho, nossas formas de perceber o mundo.

Ao pensarmos na especificidade dos saberes, isso nos remete a outra das reflexões dos especialistas na área: as transformações pelas quais nosso mundo vem passando e como essas transformações impactam as questões educacionais e escolares, impactam a forma de pensarmos a escola e, conseqüentemente, a formação dos professores que trabalharão nessas escolas.

A nossa sociedade mudou. Ela mudou de uma sociedade industrial para uma sociedade pós-industrial. Ela passou a ter outra lógica, que é a da sociedade do conhecimento, da informação, das novas tecnologias. Quando examinamos o trabalho e o local de trabalho dos professores, a forma como trabalham, percebemos que a maioria das escolas permanece inalterada, preservando características da sociedade industrial. (PIMENTA, 2002:11-12)

Nossas escolas permanecem hierarquizadas, burocratizadas, com dificuldades para organizar-se na forma do trabalho coletivo. A organização das aulas é disciplinar, com tempos e espaços delimitados, de forma isolada e fragmentada. Como coloca PIMENTA (2002), uma lógica de produção em série.

Também nossas universidades, pensadas nessa lógica do sistema escolar, permaneçam, em boa parte, com uma lógica de sociedade industrial. A formação de nossos docentes conta com grades disciplinares, estruturadas em disciplinas, que acabam por fragmentar os saberes e dificultar uma visão mais global por parte dos futuros professores.

Diante desta lógica industrial que permanece em nossos sistemas escolares, em seus diversos níveis e modalidades, espera-se dos docentes que sejam capazes de responder aos desafios da sociedade atual, em toda sua complexidade, com o processo de mudanças sociais e culturais cada dia mais velozes a que assistimos. Espera-se dos docentes capacidade de diálogo com cenários cada vez mais plurais e tecnologizados. Nos constituímos professores hoje diante de uma perplexidade: mantemos algumas estruturas e atitudes e temos que transformar outras tantas, sem termos espaço e tempo 
suficiente para pensarmos essas transformações, analisá-las e construir outras possibilidades. Pimenta caracteriza essa crise:

Os professores se questionam: o que é ser professor hoje? (...) Ao mesmo tempo em que convivemos com uma escola que mantêm o modelo da sociedade industrial, deparamos com um professor que está se questionando diante das novas exigências que a própria sociedade lhe apresenta. (PIMENTA, 2002: 13)

Este é um aspecto relevante a ser tomado em consideração em nossos cursos de formação inicial de professores: estamos num momento de transformações rápidas, de fim das certezas, de perplexidade diante das mudanças. Estamos nos constituindo professores num cenário de incertezas, de perda de credibilidade na profissão, de questionamento de verdades científicas.

Este cenário, ao mesmo tempo em que exige mais dos professores, portanto exige mais também dos processos e práticas formativas, é um cenário de desvalorização da profissão, no que tange a falta de condições materiais do trabalho docente, a própria condição de assalariado do professor e a forma de organização do trabalho nas escolas. Não se pode colocar todo o peso na formação docente, desconsiderando as condições em que ocorrem esses processos de formação e desenvolvimento profissional.

A organização social do trabalho na escola, com fragmentação do conteúdo e das funções, foi expropriando o professor de seus saberes e fazeres. O professor, diante da organização do trabalho na escola "foi sendo paulatinamente esvaziado dos seus instrumentos de trabalho: do conteúdo (saber), do método (saber fazer), restando-lhe agora, quando muito, uma técnica sem competência" (CURY, 1982:59).

Ao pensar a formação de professores é preciso pensá-la articulada com as questões do cotidiano das escolas, de como se dão as práticas pedagógicas diante da organização do trabalho dos professores. Num sistema burocratizado de ensino, onde o trabalho pedagógico está pensado de forma fragmentada, as práticas de controle e avaliação sobre o trabalho dos docentes são formas de manter o sistema, de maneira autoritária e coercitiva. Diante deste contexto pode-se entender a falta de entusiasmo percebida em alguns professores nas redes de ensino. Professores que estão alienados de seu próprio trabalho, de pensá-lo nas diversas dimensões, de construir sua autonomia profissional e ter a escola como seu espaço de ação e criação, espaço de elaboração de possibilidades pedagógicas, que colaborem para a formação dos alunos e também para o desenvolvimento profissional dos próprios docentes. 
Ao entendermos que o trabalho docente é um trabalho intelectual, reflexivo, precisamos pensar em processos de formação inicial que caminhem nessa direção: formar futuros professores que desenvolvam criticidade e autonomia na construção de usa profissionalidade docente. Podemos caminhar na direção de práticas de formação de docente que desenvolvam a consciência crítica

(...) para analisar o que acontece com o ensino (dentro e fora da sala de aula) e o modo como o contexto social mais amplo se relaciona com a função social do trabalho docente, tendo como horizonte finalidades educativas pretendidas e sua concretização, pois o ensino é uma atividade teórico-prática transformadora da realidade. (LISITA, 2006:34)

No sentido deste trabalho, pensar cursos de formação de professores que possam analisar as sociedades midiáticas contemporâneas, relacionando os processos de formação com as transformações sócio-culturais e quais interlocuções com os processos educacionais e escolares, inclusive os processos de formação docente, que estas transformações exigem.

Como destaca Almeida:

(...) importância de uma concepção ecológica da formação docente, que leve em conta o entorno, o indivíduo, o coletivo, a instituição, a comunidade, as bases implícitas subjacentes, as decisões e atitudes dos professores em um contexto específico a universidade e a sala de aula-, capaz de tornar mais eficiente sua atuação e os saberes que a sustentam. Ou seja, uma formação que tenha a prática educativa e o ensinar como objeto de análise, que assegure os elementos que permitam aos professores compreender as relações entre a sociedade e os conhecimentos produzidos, e que os ajude a desenvolver a atitude de pesquisar como forma de aprender. (ALMEIDA, 2011: 52)

Ao destacar uma concepção ecológica da formação docente, Almeida nos ajuda a pensar os entornos dos processos formativos nas sociedades midiáticas: são entornos perpassados por mídias e suas múltiplas linguagens, que colocam para os professores e para os sistemas escolares nos diversos níveis, os desafios de pensar o ensino inclusive o dos professores em processo de formação inicial - em sua complexidade como prática social na contemporaneidade.

Com estas reflexões, que não pretendem esgotar um assunto tão complexo como o da formação de professores, procurei apresentar alguns aspectos considerados relevantes pelos estudiosos da área, no que tange a processos de formação inicial de professores. Aspectos que nos remetem a pensar em como nos constituímos professores, 
cotidianamente, em cursos de formação inicial, nas práticas que acontecem nesses cursos, na cultura profissional que é veiculada por essas mesmas práticas, na interface que esses cursos de formação inicial constroem com as redes de ensino, com o cotidiano das escolas, com os desafios que se colocam todos os dias em nossas salas de aula.

Como estão estes cursos de formação em sua composição curricular? Como se apresentam os projetos pedagógicos dos cursos de formação docente? Iniciei este capítulo com um retrato das escolas e dos professores, em como está nossa construção enquanto docentes. No próximo item, discuto a formação inicial em sua relação com as instituições formadoras da região de Santos - lócus desta pesquisa - quanto à suas propostas pedagógicas, inclusive curriculares, no que tange à articulação entre educação e comunicação midiática como demanda da formação docente diante das mudanças sociais atuais.

\subsection{A formação inicial docente e as instituições formadoras:}

Para pensarmos como se dá a formação inicial de docentes nas diferentes instituições formadoras, precisamos levar em consideração como estas mesmas instituições estão estruturando sua visão educacional, suas propostas de formação, como articulam seus valores com os processos cotidianos de formação dos professores. Um dos documentos que apresenta as ideias e posicionamentos das instituições é o chamado Projeto Político Pedagógico (PPP). Como já está colocado na denominação, tem uma dimensão pedagógica e uma dimensão política, que estão entremeadas. Todo projeto serve para dar direção, apontar caminhos, onde as ações realizadas estejam orientadas por intencionalidades construídas pelos envolvidos nessas mesmas ações. Ao falarmos de projetos construídos nas escolas, falamos necessariamente de projetos coletivos, com compromissos firmados por todos os envolvidos nos processos. Para André, o projeto pedagógico deve

expressar a reflexão e o trabalho realizado em conjunto por todos os profissionais da escola, no sentido de atender às diretrizes do sistema nacional de Educação, bem como às necessidades locais e específicas da clientela da escola. (ANDRÉ, 2001:188) 
Em sua dimensão política, o projeto pedagógico destaca a intencionalidade da formação do cidadão, inserido numa determinada sociedade. Ou seja, apresenta qual cidadão pretende formar, para qual tipo de sociedade. A dimensão pedagógica define as ações educativas da escola, para que possam se realizar as intencionalidades propostas. (VEIGA, 1998).

Neste sentido, os projetos políticos pedagógicos dos cursos devem expressar às intenções dos processos de formação, as concepções de educação, as articulações das diversas ações cotidianas em prol dos rumos que se pretende trilhar.

Sob essa ótica, o projeto é um meio de engajamento coletivo para integrar ações dispersas, criar sinergias no sentido de buscar soluções alternativas para diferentes momentos do trabalho pedagógico-administrativo, desenvolver o sentimento de pertença, mobilizar os protagonistas para a explicitação de objetivos comuns definindo o norte das ações a serem desencadeadas, fortalecer a construção de uma coerência comum, mas indispensável, para que a ação coletiva produza seus efeitos (VEIGA, 2003:275)

Cabe destacar que o Brasil vem construindo estas ideias nos últimos anos, onde o Ministério da Educação - MEC - tem incentivado posturas de participação coletiva e gestão democrática, primando pelo envolvimento de todos nos processos educacionais e escolares, compreendendo a importância desses mesmos processos para o desenvolvimento do país como um todo. Entretanto, como todo processo em construção, apresenta percalços e problemas a serem resolvidos. Nem todas as instituições formadoras discutem seus projetos de forma coletiva, envolvendo todos os partícipes, quais sejam, os professores, os alunos, os funcionários e a comunidade do entorno das instituições. Esta é uma situação usual no ensino superior brasileiro, onde aproximadamente $70 \%$ das instituições são privadas e muitas vezes apresentam projetos já prontos a seus professores e não os envolvem nas discussões pedagógicas. Como apontado por Gatti, Barreto e André (2011: 114): “a relação teoria-prática tão enfatizada em documentos e normas, com a concepção curricular integrada proposta, não se concretiza no cotidiano das diferentes licenciaturas."

Ainda que se leve em conta esta situação, sem dúvida os projetos pedagógicos apresentam intencionalidades e, nos casos dos projetos de cursos de formação de professores, expressam conteúdos e formas que nos ajudam a entender como se dá a constituição do ser professor em seus processos de formação inicial. 
Um dos componentes dos projetos pedagógicos são os quadros curriculares, onde estão elencadas as disciplinas que os alunos em processo de formação cursarão.

Ao pensarmos que nos formamos professores em nossos diversos processos formativos, também assumimos como parte da formação docente estes currículos que existem nos cursos de formação inicial com os quais os alunos em formação dialogam.

Cabe destacar que os estudos sobre currículo são uma importante área de debate hoje em educação. Não existe uma única forma de compreendermos currículo e as diferentes concepções trazem debates e disputas de significado para essa área. Compreendemos currículo segundo ALVES (2004), como todas as experiências, saberes e fazeres que se entrelaçam nos diversos cotidianos das escolas, nas inúmeras redes e tessituras de conhecimentos que se constroem, envolvendo todas as pessoas que vivenciam esses cotidianos nas escolas. Currículo é, portanto, em nossa concepção, construído cotidianamente, com as crenças, representações de mundo, com todas as redes de contatos, de vivências, que trazemos para as relações sociais e que estão relacionadas ao que fazemos, falamos e construímos também em nossas escolas, nos processos educacionais vivenciados.

Como o enfoque desta pesquisa não é um estudo aprofundado sobre os currículos dos cursos de formação inicial, esclarecida nossa posição conceitual, nos ateremos, pelos próprios limites do processo de pesquisa, a discutir os currículos da formação inicial de professores em sua dimensão de quadros curriculares, ou seja, as disciplinas que são propostas, o que está colocado nas ementas dessas disciplinas e nas bibliografias apresentadas para estudo dos alunos em processo de formação. Analisaremos como aparecem, propostas pelas instituições formadoras, em seus quadros curriculares, disciplinas que relacionem as questões da formação inicial docente às formas de como trabalhar nas práticas pedagógicas também os aspectos de comunicação midiática, objeto de estudo aqui proposto.

\subsection{Os quadros curriculares dos cursos de Pedagogia da cidade de Santos e sua relação com a comunicação midiática:}

A cidade de Santos, localizada na região da Baixada Santista, Estado de São Paulo, conta hoje com seis cursos de Pedagogia, oferecidos pelas seguintes instituições: 
UNIMONTE - Centro Universitário Monte Serrat; UNIP - Universidade Paulista; UNISANTA - Universidade Santa Cecília; UNISANTOS - Universidade Católica de Santos; UNIMES - Universidade Metropolitana de Santos e UNILUS - Centro Universitário Lusíadas. São cinco cursos presenciais e um curso à distância - o da UNIMES. Todos os cursos são oferecidos por instituições privadas. Quatro por Universidades e dois por Centros Universitários. Trabalharemos com os quadros curriculares desses cursos, visto que a maior parte dos professores em atuação na rede municipal de Santos é formada por um destes cursos. Discuto dados da pesquisa de campo relativa aos professores e suas atividades docentes no capítulo 4 .

Em seguida, apresentaremos, resumidamente, os quadros curriculares dos seis cursos, no aspecto que aqui nos interessa: a relação entre a formação inicial de professores e os aspectos do preparo desses docentes para trabalharem com mídias nas escolas, em sua atuação profissional. Destacarei a relação entre o total de disciplinas propostas, a carga horária total de formação do curso e à proporção que está direcionada, de forma mais específica, a tratar da relação entre aspectos educacionais e comunicacionais. Esta é uma primeira abordagem para trazer à reflexão a relação existente hoje entre a formação inicial de professores e os aspectos relacionados à comunicação midiática, numa sociedade tecnologizada como a nossa. Necessário pensarmos como estão as propostas, inclusive em termos de carga horária, para os cursos de formação de professores e analisarmos se essa carga horária proposta está de acordo com as exigências das quais falamos ao longo deste capítulo, quais sejam: as de uma sociedade com novas demandas, também no que tange a aspectos educacionais e escolares, demandas estas relacionadas ao desenvolvimento tecnológico, a entrada cada vez maior de aparatos tecnológicos em nossas vidas cotidianas, trazendo novas formas de ser e estar no mundo, novas formas de nos relacionarmos enquanto seres humanos. A discussão das cargas horárias é, portanto, apenas uma faceta da nossa reflexão, considerando que os números podem nos ajudar a pensar sobre as questões relacionadas à formação de professores e sua relação com uma sociedade midiática comunicacional. (Os quadros curriculares completos dos cursos de Pedagogia estão nos anexos A, B, C, D, E e F)

Dos seis cursos de Pedagogia da cidade de Santos, cinco fazem referência direta, nos quadros curriculares, à presença de disciplinas que trazem em seu título e suas 
ementas, aspectos da formação docente relacionados às novas tecnologias e às questões midiáticas comunicacionais.

Comecemos pelos cursos dos dois centros universitários, UNILUS e UNIMONTE. No curso do UNILUS, a matriz curricular apresenta entre as disciplinas elencadas no $1^{\circ}$. ano a disciplina "Tecnologias Aplicadas à educação", com carga horária de 80 h. O quadro total de horas do curso é de 3280 horas, sendo destas, portanto, 80 horas destinada a discutir especificamente a relação entre tecnologia e educação. Portanto, podemos considerar que, aproximadamente, 2,43\% do curso de Pedagogia do UNILUS discute temas específicos relacionados à comunicação e educação.

No curso do UNIMONTE, com carga horária total de 3280 horas, no $8^{\circ}$. módulo aparece à disciplina: "Educação e Tecnologias", com uma carga horária de 80 horas, num percentual de $2,5 \%$ diante do total de horas de formação proposta aos alunos.

Quatro cursos de Pedagogia são oferecidos por Universidades. São elas: UNISANTOS, UNISANTA, UNIMES e UNIP.

Na matriz curricular da UNISANTA, o $1^{\circ}$. semestre traz a disciplina "Educação e Tecnologias I" e o $2^{\circ}$. semestre a disciplina "Educação e Tecnologias II", cada uma com respectivamente 72 horas. Com um total de 3280 horas de formação, 144 h são direcionadas a discutir a relação entre educação e tecnologias, num percentual de 4,39\% em relação à carga total da formação docente.

No quadro curricular da UNIP, com um total de 3200 horas, aparecem as disciplinas "Didática para o ensino à distância", ofertada no $6^{\circ}$. semestre e "Informática: tecnologias aplicadas à educação", no $2^{\circ}$. Semestre, cada uma com carga horária de 36 horas, numa proporção diante do total da carga de 2,25\%.

No curso de Pedagogia - ensino a distância - EAD - da UNIMES, no primeiro ano temos a disciplina Comunicação, Educação e Tecnologias, com uma carga horária de $80 \mathrm{~h}$, diante da carga total do curso que é de 3570 horas, trazendo, portanto, um percentual de 2,24\% de carga referente à assuntos específicos da relação entre educação, tecnologias e comunicação.

No quadro curricular da UNISANTOS, não aparece uma referência direta a relação entre comunicação, educação e tecnologias no nome de nenhuma das disciplinas. As disciplinas que indicam alguma possibilidade de discussão sobre a relação entre educação e comunicação são: nos $3^{\circ}$ e $4^{\circ}$ semestres - "Gestão da 
Informação I e II", respectivamente, com carga horária de 34 h cada uma diante da carga total do curso de 3278 horas, o que nos daria um percentual de 2,07\% de disciplinas que discutem a relação entre comunicação e educação.

Percebe-se, portanto, que ainda que todos os quadros curriculares apresentem disciplinas que fazem referência à relação entre comunicação e educação, a presença, em termos de carga horária diante do quadro total de horas de formação, é mínima diante das demandas da sociedade atual e das novas formas pelas quais as crianças aprendem, exigindo uma formação de professores compatível com essas transformações. O curso que apresenta uma quantidade maior de horas dedicada diretamente ao tema oferece $4,39 \%$ da carga horária total do curso. Se pensarmos na importância que o tema tem hoje, podemos dizer que os cursos de formação inicial não estão dando destaque para as questões educomunicacionais, ainda não tem uma estrutura curricular articulada às interfaces entre questões comunicacionais $\mathrm{e}$ educacionais, necessitando pensar em como é possível realizar um repensar dos processos formativos.

Em pesquisa realizada por GATTI e BARRETO (2009), com cursos de formação de professores em todo o Brasil, aparece dado semelhante. As pesquisadoras fazem uma categorização quanto às disciplinas obrigatórias presentes nas estruturas curriculares dos cursos de formação inicial docente e evidenciam que os conhecimentos relativos às tecnologias estão na categoria de análise "conhecimentos relativos à formação profissional específica", na subcategoria "tecnologias" e aparecem num percentual de $0,7 \%$ nos quadros curriculares. Outra categoria utilizada pelas pesquisadoras foi a categoria “outros saberes', que incluía as disciplinas que ampliam o repertório dos professores como, temas transversais, novas tecnologias etc. Essa categoria aparece, em termos de Brasil, oferecida em 5,6\% dos cursos de formação de professores, número bastante próximo aos encontrados nas estruturas curriculares dos cursos de Pedagogia da cidade de Santos.

Analisados estes quadros percebe-se que existe, por parte das instituições formadoras - pelo menos quanto aos quadros curriculares - uma atenção pequena em termos de quantidade de horas diante do computo geral de horas dos cursos - ao aspecto do preparo do futuro docente para seu trabalho com a questão das mídias comunicacionais em sua relação com processos educacionais. 
Ao evidenciarmos o impacto que as novas tecnologias trazem para a constituição da dinâmica social, evidenciamos também o impacto que trazem para as escolas, para o cotidiano dos processos de ensino aprendizagem, o que traz novas exigências para os processos de formação de professores. Como coloca Citelli:

A despeito dos novos paradigmas sociotécnicos, da ambiência mediática, da presença dos nativos digitais, de formas de sensibilidade e sociabilidade orientadas por outras percepções dos vínculos entre tempo e espaço, os programas de formação para o magistério tendem a permanecer amarrados a outros contornos epistemológicos, certamente de extrema importância em suas singularidades, mas insuficientes para abranger demandas, expectativas, contradições, jogos de linguagem, operações de acobertamentos e revelações, que a amplitude da comunicação oferece à vida social. (CITELLI, 2011: 61-62)

Há necessidade de repensar práticas didáticas e pedagógicas e está reflexão precisa estar presente nos cursos de formação inicial de professores, onde os futuros docentes têm tempo e espaço para reflexões, para construir novas possibilidades pedagógicas, onde podem entrar em contato, também em seus processos de formação inicial, com maneiras de se relacionar com novas linguagens, com sistemas de signos veiculados em suportes diferentes dos tradicionais.

Os dados trazidos no estudo nacional de ementas das estruturas curriculares apontam como estão nossos cursos de formação inicial na constatação de GATTI e BARRETO:

\begin{abstract}
Destaque-se o desequilíbrio na relação teoria- prática, em favor do pretenso tratamento de fundamentos e teorizações. Note-se que a escola é objeto quase ausente nas ementas, o que leva a pensar numa formação de caráter mais abstrato e pouco integrado ao contexto concreto em que o profissional professor deve atuar, haja vista que, dentre as ementas examinadas, podese encontrar referência explícita à palavra escola em apenas $8 \%$ delas. (GATTI e BARRETO, 2009: 130-131)
\end{abstract}

Estamos nos construindo professores de uma forma um pouco distante em relação ao cotidiano das nossas escolas, aos nossos cotidianos sociais! As matrizes curriculares dos cursos de formação inicial, em função das diferentes realidades que vivenciamos nas sociedades contemporâneas, podem ser revistas, repensadas, trazendo em seu bojo uma articulação mais consistente com as realidades das escolas e das crianças e jovens atuais, trazendo uma articulação mais consistente entre as questões da educação e as questões da comunicação, trazendo um pensar sobre a formação docente 
numa sociedade perpassada por mídias, por avanços tecnológicos constantes e impactantes em todo o tecido social.

As propostas de formação das instituições educacionais necessitam estar atentas a questões contemporâneas, atentas no que se refere a mudanças tecnológicas e comunicacionais e como essas mudanças impactam o cotidiano das escolas.

Os estudiosos da área de formação de professores, como apresentamos acima, destacam a necessidade de uma formação inicial mais conectada às dimensões do cotidiano, uma formação inicial que ajude os professores, na constituição de sua profissionalidade docente, a refletir sobre as questões educacionais e escolares em sua relação com as questões sócio culturais e construir possibilidades efetivas de ação e transformação na direção da construção de uma escola mais cidadã, articulada a construção de uma sociedade mais igualitária e democrática. Nas palavras de PIMENTA:

Qual é o papel da escola na sociedade hoje? É garantir o acesso ao conhecimento de qualidade por parte de todas as crianças e jovens a esse instrumental, a fim de que se situem no mundo. Um mundo que é rico em avanços civilizatórios. E, em decorrência, apresenta imensos problemas de desigualdade social, econômica e cultural. De valores. De finalidades. A tarefa da escola é inserir as crianças e jovens tanto no avanço como na problemática do mundo de hoje, pela reflexão, pelo conhecimento, pela análise, pela compreensão, pela contextualização, pelo desenvolvimento de habilidades e atitudes. (PIMENTA, 2002: 62)

Para que a escola se situe desta forma, capaz de colaborar na inserção cidadã das crianças e jovens no mundo contemporâneo, a formação de professores precisa estar articulada com essas mesmas questões, para preparar professores capazes de se situarem no mundo, refletir sobre a sociedade em que estão inseridos, capazes de fazer análises das conjunturas sócio culturais, de buscar caminhos alternativos para os problemas que se apresentam, capazes de fazer a gestão dos processos de sala de aula, na construção de uma escola mais democrática e cidadã.

Diante da sociedade atual, com novas demandas em diversos setores, principalmente nos referentes à comunicação e sua implicações na educação, há falta de políticas de formação de professores voltadas, de forma mais específicas, para essas questões da educomunicação. O país precisa de um projeto formativo claro de acordo com as necessidades e objetivos reais para as escolas atuais, que entre outras questões, também considere a necessidade urgente de articular as questões educacionais a 
questões comunicacionais, área tão estratégica para o desenvolvimento dos países, para um desenvolvimento que considere a autonomia do ser humano, sua capacidade crítica, seu posicionamento claro diante das questões fundamentais que envolvem o viver em sociedade. Segundo Almeida:

(...) necessidade de formar um professor capaz de desenvolver uma cultura profissional que lhe assegure o papel e a possibilidade de ser, individual e coletivamente, um agente de mudança que dê conta de enfrentar situações problemáticas contextualizadas, em meio às quais ele saiba não só o que fazer e como fazer, mas também porque e para que fazê-lo. Ou seja, falamos de um processo formativo sustentado na articulação teoria-prática, onde o professor desenvolva a capacidade de olhar para si, para o ensino e para a aprendizagem enquanto um processo de ação dinâmica, vivo, contextualizado e transformador, ou seja, uma prática social complexa. (ALMEIDA, 2011:54)

Esta complexidade da prática docente contemporânea exige a produção de conhecimentos que possam fundamentar tal prática. Esses conhecimentos podem ser construídos a partir de saberes trabalhados nos cursos de Pedagogia, nos cursos de formação inicial de docentes. Saberes construídos coletivamente pelos docentes, os que estão já formados, portanto em processos de formação contínua e os que estão em processos de formação inicial, ressignificando os cotidianos escolares, a partir de uma concepção epistemológica da prática, que promova uma articulação entre teoria e prática capaz de fertilizar nossas escolas e seus processos de ensino e aprendizagem.

Como colocado por Gatti, Barreto e André, há necessidade de políticas públicas voltadas para a formação docente que sejam mais claras e incisivas, pois

O problema da formação do licenciado como profissional professor se acha descurado de sua qualidade na direção do perfil de profissional com condições mínimas de adentrar em uma escola em que crianças e jovens em desenvolvimento dependem de seu trabalho para chegar à cidadania plena. (GATTI, BARRETO e ANDRÉ, 2011: 117)

Portanto, as políticas docentes também precisam debruçar-se sobre a complexidade das sociedades atuais, colaborando para que haja articulação entre teoria e prática nos processos de formação inicial de docentes, preparando-os para as múltiplas realidades com as quais se defrontarão em seus tempos e espaços de trabalho. Ainda cabe destacar que, embora muitas iniciativas e propostas de mudanças sejam apresentadas quanto à formação inicial de professores, os pesquisadores alertam que não se tem mexido no ponto nevrálgico: 
As gestões educacionais e as universidades têm apenas proposto reformulação deste ou daquele aspecto desses cursos, não tocando no âmago da questão, tão bem salientado nas análises: sua estrutura institucional e a distribuição de seus conteúdos curriculares. (GATTI, BARRETO e ANDRÉ, 2011:135)

Ressalte-se que a maior parte dos cursos de formação de professores está sob o controle da iniciativa privada, o que inclui as licenciaturas em geral e, principalmente, os cursos de Pedagogia. O governo federal brasileiro tem ampliado sua participação nos processos de formação inicial de professores, com cursos voltados a essa questão e também com ações via ensino à distância. Entretanto, os cursos de Pedagogia, onde formamos os professores polivalentes do ensino fundamental e da educação infantil são predominantemente privados. ${ }^{11}$ Embora esse não seja o foco desta pesquisa, são dados que trazem a premência de reflexões e análises diante da complexidade das relações de poder que estão permeando os processos formativos dos docentes.

Ainda destaco outra situação a ser levada em consideração. "Ao falar de qualidade dos professores da educação básica, também se está indiretamente referindo aos gestores de escolas que, de origem, são professores." (GATTI, BARRETO e ANDRÉ, 2011:28). Aqueles que podem colaborar na articulação dos processos escolares, junto aos docentes, também foram formados nos cursos de Pedagogia, portanto tem as mesmas fragilidades já apontadas em seus processos formativos. Os gestores das escolas foram formados diante do quadro que apresentamos: com uma formação mais teórica do que vinculada com as práticas, com um olhar que pouco se debruça diante das realidades das escolas concretas. No caso do foco desta pesquisa, foram formados com poucas discussões e vivências quanto aos aspectos educomunicacionais, quanto às interfaces entre processos escolares e sociedades midiáticas.

A formação de profissionais professores para a educação básica tem de basear-se em seu campo de prática, com seus saberes, integrando-os com os conhecimentos necessários como valorosos, em seus fundamentos e com as mediações didáticas necessárias, sobretudo por se tratar de formação para o trabalho educacional com crianças e adolescentes. (GATTI, BARRETO e ANDRÉ, 2011:136)

Destacando que hoje a prática é perpassada pelas questões midiáticas, os saberes são atravessados pelas múltiplas linguagens, nos mais variados suportes, com os quais

\footnotetext{
${ }^{11}$ Segundo o Censo 2010 da Educação Superior, são os seguintes os números de matrículas em cursos de graduação presenciais de Pedagogia: total de matrículas: 297.581, sendo 36.120 em instituições federais, 52.104 em estaduais, 5.662 em municipais e 203.695 em instituições privadas. (portal.inep.gov.br, acesso em 27.01.12)
} 
convivemos todos os dias, nós professores e nossos alunos, inclusive os que estão em processo de formação para a docência.

Para aprofundarmos a compreensão das questões que relacionam aspectos da formação de professores a aspectos comunicacionais e tecnológicos da sociedade contemporânea, no próximo capítulo discutimos a formação docente e sua relação com a comunicação, com as mídias e suas interfaces com a educação e o cotidiano das escolas. Discutiremos o que está proposto nas ementas das disciplinas acima elencadas e quais outros aspectos e elementos formativos dos cursos de professores que podem colaborar na construção da identidade de um profissional preparado para novas demandas sociais que interpelam os processos de ensino e aprendizagem nas sociedades midiáticas contemporâneas. 


\section{CAPÍTULO 3 - FORMAÇÃO DE PROFESSORES E INTERFACES COM PROCESSOS COMUNICACIONAIS MIDIÁTICOS}

Ao iniciarmos este capítulo, que discutirá a formação inicial de professores e sua relação com aspectos comunicacionais midiáticos nas interfaces com processos de ensino aprendizagem, necessariamente temos que questionar mais uma vez: Para qual sociedade formamos professores? Quais nossas concepções e convicções sobre a vida, sobre as relações entre os seres humanos? Quais nossos sonhos diante da realidade em que estamos inseridos? Quais nossos objetivos diante da vida e da sociedade, nós, que formamos os formadores?

REZENDE E FUSARI nos convoca a uma atitude de responsabilidade social:

Tendo em vista a responsabilidade de nosso trabalho como educadores - e portanto comunicadores - junto a crianças, jovens, adultos na escola ou fora dela, precisamos olhar e pensar essa comunicação de concepções, de atitudes, de convicções sobre a vida no mundo e que tem sido por sua vez pensada, feita, expressada em nosso cotidiano, colocando em cena os modos de relacionamentos sociais entre as pessoas. (REZENDE E FUSARI 1994: 22)

Portanto, é responsabilidade nossa, enquanto formadores de professores, que também somos, em nosso trabalho cotidiano, comunicadores - de concepções, de atitudes, de crenças - pensarmos em como acontecem os processos comunicacionais na sociedade atual, como estão as interfaces entre os processos comunicacionais e os processos educacionais e escolares. Pensarmos a formação de professores diante de um cenário de transformações e mudanças, que impactam as maneiras que apreendemos o mundo, que impactam nossas relações sociais, que impactam as formas de ver, sentir e pensar das nossas crianças e jovens. Transformações que impactam as formas de ser e estar no mundo de todos nós, inclusive nós professores!

Pensamos que a escola, neste início de século XXI, tem como um de seus papéis, como agência socializadora e criadora de cultura, colaborar na análise dos processos comunicacionais, na interpretação das novas linguagens que circulam socialmente e, sobretudo, colaborar na produção de comunicação pelos alunos. Que sejam mais do que receptores de ideias, imagens e representações sobre o mundo. Que sejam produtores sociais de comunicação. 
Nas palavras de Libâneo:

Não dizemos mais que a escola é a mola das transformações sociais. Não é, sozinha. As tarefas de construção de uma democracia econômica e política pertencem a várias esferas de atuação da sociedade, e a escola é apenas uma delas (...) tem também, o compromisso de ajudar os alunos a tornarem-se sujeitos pensantes, capazes de construir elementos categoriais de compreensão e apropriação crítica da realidade. (LIBÂNEO, 1998: 09-10)

Para que nossos alunos sejam produtores de comunicação, se apropriem criticamente da realidade, nossos professores igualmente têm que ser vistos como produtores sociais de comunicação, com capacidade de leitura de mundo e leitura de palavra (FREIRE, 1971), formados para uma realidade comunicacional tecnologizada e midiática, capazes de analisar, mediar e ressignificar informações, imagens, ideias, que estão inscritas nos inúmeros artefatos culturais dos nossos tempos.

Vivemos um momento histórico repleto de perplexidades, com um desenvolvimento científico e tecnológico cada vez mais acelerado, numa crise de paradigmas, que nos traz sempre muitas incertezas diante de nossas escolhas cotidianas. Incerteza dos caminhos, incerteza dos valores, incertezas vividas também no campo profissional.

Nos últimos 50 ou 60 anos, vivemos transformações tecnológicas que impactaram a cultura, as formas de relacionamento humano, a produção e circulação de informações. A televisão entrou como forma de comunicação em nossas casas, por volta de 1950. Primeiro preto e branco, depois a cores, trazendo imagens do mundo todo, ao vivo, para toda família. Trazendo representações de mundo, ideias e emoções. Muito mais do que um suporte ou recurso, uma nova forma de linguagem, uma tela a nos trazer determinadas formas de ver o mundo. Tela pela qual passamos a ver o mundo!

Como nos coloca Fisher, tela que participa de nossos processos de formação pessoais:

A TV, na condição de meio de comunicação social, ou de uma linguagem específica ou ainda na condição de simples eletrodoméstico que manuseamos e cujas imagens cotidianamente consumimos, tem uma participação decisiva na formação das pessoas - mais enfaticamente, na própria constituição do sujeito contemporâneo. Pode-se dizer que a TV, ou seja, todo esse complexo aparato cultural e econômico - de produção, veiculação e consumo de imagens e sons, informação, publicidade e divertimento, com uma linguagem própria - é parte integrante e fundamental de processos de produção e circulação de significações e sentidos, os quais por 
sua vez estão relacionados a modos de ser, a modos de pensar, a modos de conhecer o mundo, de se relacionar com a vida. (FISHER, 2006:15)

Portanto, ao nos referirmos às mudanças tecnológicas dos últimos 50 anos, não estamos falando simplesmente de recursos de comunicação. Estamos falando de novas formas de participarmos do mundo, novas formas de significação dos processos sociais, novas sociabilidades. Estamos refletindo sobre todo um complexo aparato cultural e econômico, que veicula ideias sobre o estar no mundo, sobre o nosso agir cotidiano e que traz impactos para a vida nas escolas, para as formas de pensarmos os processos educacionais. Estamos falando dos desafios que as mudanças na comunicação trazem para as questões educacionais e escolares. Não é um desafio que fica restrito a como nos apropriarmos de dispositivos tecnológicos, restrito a como usarmos as tecnologias na educação, mas nos traz a necessidade de pensarmos em uma nova ambiência cultural, pensarmos em ecossistemas comunicativos - compreendidos como sistemas complexos, dinâmicos e abertos, conformados como espaço de convivência e ação comunicativa integrada (Soares, 2011) - em sua relação com os sistemas educacionais e escolares, igualmente complexos e dinâmicos.

Nestes últimos 50 anos, além da entrada da TV em nosso cotidiano social, também tivemos o advento da internet, com a possibilidade de termos computadores pessoais ligados a uma rede mundial de computadores. Hoje, uma parte considerável de nós, interage com o cotidiano por meio da tela do computador. Escrevemos e-mails, participamos de redes sociais, pesquisamos em sites diversos, lemos as notícias do dia.

As indústrias culturais (rádio, cinema, televisão, impressos) viveram uma verdadeira revolução tecnológica decorrente do progresso técnico nas telecomunicações e na informática, cujo resultado é a digitalização de praticamente todos os dispositivos técnicos no trabalho ou em casa, particularmente os de comunicação. Tal revolução veio colocar à disposição de cada indivíduo possibilidades pletóricas de comunicação e de acesso à informação e ao conhecimento, configurando uma nova paisagem comunicacional e informacional. (BELLONI, 2009: XII)

Esta nova paisagem comunicacional e informacional, este novo ecossistema comunicativo, nos traz informações de forma contínua, acelerada, num ritmo quase impossível de acompanhar em nosso cotidiano. O entendimento de ecossistema como sistema complexo, como teia de relações, nos ajuda a pensar as interfaces entre 
comunicação e educação e toda a complexidade de sujeitos, ações e saberes envolvidos nesses processos.

Obviamente, nossas formas de comunicação atuais, via TV, via Internet, trazem inúmeras possibilidades: de nos expressarmos, comunicarmos ideias e sentimentos, de termos acesso a fontes diversas de informação. Mas, nossas formas de comunicação também trazem desafios, inclusive no que tange às questões educacionais. As questões educacionais e escolares estão hoje perpassadas por mudanças culturais relacionadas às mudanças tecnológicas nas práticas de comunicação e informação. Ao mesmo tempo em que a TV, a Internet, os Ipods, MP3, telefones celulares multifuncionais podem ampliar o acesso à cultura e informação, também trazem novas interpelações, inclusive nas publicidades e propagandas que apresentam. Nas palavras de FISHER (2006), a TV e outras mídias operam como processadores do que ocorre no tecido social. As informações e ideias que temos da realidade social são apresentadas pelas mídias, narradas, mostradas, significadas nessas mídias. Ao ler notícias de uma guerra, ao lermos sobre um filme no cinema, ao assistirmos a um capítulo de novela, entramos em contato não somente com as informações, mas elaboramos, a partir dessas informações, relacionadas a nossos conteúdos, formas de entender a sociedade, construímos formas de nos posicionarmos diante do que vemos. Ou seja, construímos ideias, construímos representações de mundo e das relações humanas. Em outra palavra, aprendemos!

Não há dúvida, por exemplo, de que a TV seria um lugar privilegiado de aprendizagens diversas; aprendemos com ela desde formas de olhar e tratar nosso próprio corpo até modos de estabelecer e de compreender diferenças de gênero (isto é, de como "são" ou "devem ser" homens e mulheres), diferenças políticas, econômicas, étnicas, sociais, geracionais... Estou falando em modos de existência narrados através de sons e imagens que, a meu ver, tem uma participação significativa na vida das pessoas, uma vez que de algum modo pautam, orientam, interpelam o cotidiano de milhões de cidadãos brasileiros - ou seja, participam da produção de sua identidade individual e cultural e operam sobre a constituição de sua subjetividade. (FISHER, 2006: 16)

Pensar as novas tecnologias de informação e comunicação - a TV, o computador etc - é pensar sobre formas de expressão culturais contemporâneas, que estão justamente expressas nessas novas tecnologias, que por sua vez estão presentes e circulam no cotidiano social, nas formas de trabalho, nas formas de comunicação, nas formas que aprendemos e ensinamos. As escolas e os professores atuais estão inseridos nessa sociedade midiática, nesse campo cultural perpassado por transformações 
tecnológicas aceleradas, pela velocidade dessas transformações. Um campo cultural que traz, junto a essas novas tecnologias, outras formas de sociabilidade, onde compartilhamos muito mais informações, interagimos uns com os outros e temos processos comunicacionais mais flexíveis, onde quem recebe mensagens - receptor assume uma posição nunca vista antes, pois tem a sua frente, devido à tecnologia, inúmeras possibilidades de ser o emissor de outras mensagens, de interagir com outros usuários. As transformações e avanços tecnológicos permitem a figura hoje, com participação ativa, nas mídias, de um sujeito produtor. Para pensarmos nisso, somente um exemplo, relacionado ao Youtube ${ }^{12}$ :

gera uma nova sociabilidade do receptor-emissor, do antes agente passivo da comunicação que só via e agora tem uma TV ambulante precisando apenas de um celular, uma câmera fotográfica que filme e um computador conectado à Internet para espalhar seus vídeos pelo mundo de ter sua emissora de televisão própria. (BERTI, 2010:7)

Estamos assistindo a possibilidades comunicacionais nunca vistas antes, potencializadas pelos avanços tecnológicos, pela convergência das mídias, por novas linguagens e formas de comunicação. Estas novas possibilidades comunicacionais interpelam a escola, interpelam os professores em exercício nessa escola. Interpelam os cursos de formação docente, local do preparo inicial dos professores para o seu trabalho social. As mudanças tecnológicas comunicacionais nos constituem, enquanto sujeitos, de forma diferenciada. Temos hoje rotinas diferenciadas em função dos artefatos midiáticos contemporâneos. Temos possibilidade de informação e comunicação quase instantâneas, numa velocidade que não imaginávamos antes. Vivemos uma era acelerada, volátil, onde nos tornamos mais imediatistas todos os dias, vivendo de forma sempre mais rápida, com inúmeras opções diante de nós.

As novas tecnologias trazem novos desafios para a relação entre comunicação e educação. Entre eles, o desafio de lidar com uma cultura midiática interativa e participativa, novos delineamentos entre quem tem o poder de transmitir mensagens e quem as consome, novas formas de perceber o mundo e de aprender, novas formas de ser cidadão. Como nos coloca Machado (2009), temos colocado hoje, explicitado pelo diálogo necessário entre comunicação e educação, o desafio do trabalho com a dialogicidade e a alteridade. Todas as potencialidades colocadas pela interface

\footnotetext{
${ }^{12} \mathrm{O}$ YouTube é um site que permite que seus usuários carreguem e compartilhem vídeos em formato digital.
} 
educomunicacional dependem das formas com as quais vamos nos relacionar com as mídias, nós enquanto professores e também como vamos ensinar as novas gerações a se relacionarem com as novas possibilidades geradas por essa multiplicidade de formas de ver, geradas por essa multiplicidade de signos e suportes. As relações que as crianças e jovens vão estabelecer e construir com as mídias e suas potencialidades dependem de estarem apropriados da linguagem dessas mídias, apropriados das formas de construção de sentidos apresentadas nessas mídias. Para que os jovens e crianças se apropriem, para que reflitam e articulem seus posicionamentos e criações, dependem em boa parte da articulação e análise feitas por seus professores, no ambiente das escolas, com tempo e espaço para pensarem sobre a cultura, para debatê-la, com tempo e espaço para criação e recriação, tempo e espaço para que se apropriem das novas linguagens de formas mais democráticas, críticas e criativas. Por sua vez, os professores, para que articulem novas formas de trabalho com as mídias, necessitam de tempo, espaço e recursos para trabalharem essa articulação.

Será necessário que a mídia-educação penetre efetivamente nos sistemas de ensino, de modo interdisciplinar e transversal, oficial e integrado ao cotidiano das práticas pedagógicas. Isto exige uma mudança de escala imprescindível, acompanhada de profundas transformações culturais, não apenas na formação de professores, embora esta seja condição sine-qua-non, mas também e, sobretudo na definição de políticas públicas; é preciso que a vontade política responda à demanda social e que a mídia-educação seja inscrita nas prioridades educacionais, o que depende da convicção e da mobilização de educadores comprometidos com a qualidade do ensino e com a cidadania. (BELLONI, 2009: XIV - XV)

As questões educomunicacionais, questões relativas à mídia-educação, precisam estar pautadas nas políticas públicas, como nos alerta Belloni. Enquanto educadores, inscritos na vida das sociedades contemporâneas, precisamos assumir um papel ativo na discussão e elaboração de propostas que colaborem para uma ação docente articulada às questões socioculturais atuais, ou seja, articulada também as questões midiáticas que conformam as sociedades em que vivemos. Trabalhar não só na dimensão da recepção crítica, mas para além, na dimensão de quem organiza e gere processos comunicacionais, com o objetivo de "ampliar a prática da cidadania mediante a aprendizagem sobre como aplicar a gestão participativa e democrática dos recursos da informação nos espaços educativos." (MACHADO, 2009: 33) 
Enquanto professores, podemos trabalhar com as inúmeras possibilidades proporcionadas pelas novas tecnologias, ampliando o poder de expressão e comunicação entre todos os sujeitos envolvidos nos processos educacionais e escolares, permitindo desenvolvimento da criticidade e criação.

Para poder discutir novas propostas educacionais, perpassadas pelas questões comunicacionais midiáticas e articuladas às demandas sociais atuais, é preciso que, como professores, tenhamos clareza das mudanças sociais e como estas estão relacionadas à nossa função docente.

Assim, discuto em seguida como as mudanças sociais e culturais afetaram o papel dos docentes, exigindo um repensar dos cursos de preparo inicial destes docentes para seu trabalho em escolas constituintes e constituídas por um campo cultural midiático tecnologizado.

\subsection{As mudanças no papel dos docentes:}

Nesse contexto de modernidade radical, de ambivalência entre o global e o local na construção do mundo vivido e refletido, de obsolescência rápida dos saberes e das técnicas, o papel da escola em todos os níveis é cada vez mais a formação do cidadão competente para o futuro. Como formar o cidadão frente à influencia avassaladora da mídia e no quadro de uma cultura pós moderna fragmentada e fragmentadora? Qual o papel da escola nesse processo? Quem, mais uma vez, educará os educadores? E quem forma os comunicadores? (Maria Luíza Belloni)

As mudanças tecnológicas e culturais dos dias atuais trazem impactos para a atuação dos docentes na sociedade, obrigando a um repensar destas funções diante das demandas das sociedades contemporâneas. Alguns autores, como ESTEVE (1995) e NÓVOA (1995), falam sobre os tempos paradoxais que os professores tem vivido em seu cotidiano profissional. A sociedade vem exigindo cada vez mais dos professores, exigindo transformações na escola e nas práticas pedagógicas que possam dar respostas mais efetivas a todo esse quadro de mudanças sócio culturais a que assistimos. No entanto, essa cobrança que é feita aos professores e a sua competência profissional, não é correspondida na forma de dar-lhes condições para pensar e elaborar sua profissionalidade docente. ESTEVE (1995) apresenta uma comparação muito interessante ao dizer que as mudanças sociais cada vez mais aceleradas podem ser comparadas ao ato de encenar uma peça teatral, onde os atores estão vestindo trajes de 
uma determinada época e são surpreendidos, no meio da encenação, pela mudança de cenário, tornando assim suas vestimentas fora de contexto, inadequadas, provocando risos na platéia e momentos de tensão e desconserto entre os atores.

O problema reside em que, independentemente de quem provocou a mudança, são os atores que dão a cara. São eles, portanto, quem terão de encontrar uma saída airosa, ainda que não sejam os responsáveis (...) Em qualquer caso, a palavra mal-estar poderia resumir os sentimentos deste grupo de atores perante uma série de circunstâncias imprevistas que os obrigam a fazer um papel ridículo. (ESTEVE, 1995:97)

As mudanças sociais, inclusive as mudanças tecnológicas - cada dia mais rápidas - atingem o cotidiano dos professores e suas funções docentes. Neste sentido, atingem a própria imagem que o docente tem de si e de seu trabalho, influenciando a forma de constituição do seu ser docente, a constituição de sua profissionalidade docente. Alguns elementos da mudança estão diretamente relacionados ao trabalho dos professores; outros elementos estão indiretamente relacionados ao cotidiano docente e diretamente relacionados a mudanças no contexto social de forma mais ampla. Quase todos os aspectos dessas mudanças sociais estão relacionados a mudanças que também dizem respeito a processos de comunicação e seus conteúdos e dimensões.

Um dos fatores ligados ao contexto social e que atinge as práticas docentes é o aumento das exigências em relação ao trabalho dos professores. Espera-se dos professores hoje que cumpram um leque variado de atividades: ensinem os conteúdos, trabalhem com os alunos com necessidades especiais, facilitem o processo de aprendizagem, organizem atividades em grupo, dentre outras. A esse aumento das exigências, não correspondeu uma efetiva mudança nos cursos de formação de professores, que têm, na maioria dos casos, a mesma formatação que tinham anos atrás. Entre as exigências, pode-se destacar que se espera que o professor consiga trabalhar com novas linguagens, que domine os avanços tecnológicos e articule-os com seu cotidiano docente. Também para isso não estão sendo preparados em seus cursos de formação inicial.

Um segundo fator das mudanças sociais que incide sobre o trabalho docente é a inibição educativa de outros agentes de socialização, onde papéis educativos que eram, por exemplo, da família, passam a ser exigidos das escolas e dos professores. Um terceiro fator está relacionado ao desenvolvimento de fontes de informação alternativas à escola, levando o professor a ter que rever seu papel de transmissor de conhecimentos. 
Os meios de comunicação têm um potencial informativo que os professores necessitam integrar em seu trabalho, a cada dia mais, em função do desenvolvimento constante de novas possibilidades tecnológicas desses meios. Outro fator das mudanças sociais é a ruptura do consenso social sobre os objetivos da educação. Tínhamos processos de socialização convergentes, com o papel da escola claramente definido. A atual sociedade, multicultural e multilíngue, traz o desafio da incorporação, no cotidiano escolar, de culturas diversas, de realidades que se conflitam. Os professores precisam dialogar com todas essas culturas e desenvolver uma competência para esse diálogo multicultural.

Essa ruptura no consenso social sobre o papel da educação traz em conjunto o aumento das contradições no exercício da docência. Uma sociedade multicultural traz inúmeros apelos e demandas diferenciadas, nem sempre sendo possível integrar todas essas demandas ao trabalho docente, nas opções que o professor faz para realizar seu trabalho cotidiano. ESTEVE (1995) afirma que o professor fica sujeito a críticas constantes, críticas tanto no que se refere a valores como críticas quanto a suas opções metodológicas. FAURE (1973) traz outro ponto que nos faz pensar sobre as contradições vivenciadas pelos professores, ao afirmar que se pede hoje que os docentes preparem os alunos para uma sociedade que ainda não existe, para uma configuração social que está em pleno processo de criação. Outro ponto a afetar o trabalho docente está relacionado a mudanças de expectativas em relação ao sistema educativo. Se antes era um sistema voltado ao ensino das elites, hoje é um sistema de ensino de massas, com uma valorização social diferente, exigindo adaptação frente a essa nova realidade. Aliado a este ponto, temos a modificação do apoio da sociedade ao sistema educativo. A expansão do sistema escolar não garantiu a igualdade social, trazendo diversas situações conflitantes. Em geral, o professor foi culpabilizado pelos problemas dos sistemas de ensino, como grande responsável pelo fracasso das propostas.

O julgamento social dos professores tem vindo a generalizar-se. Desde os políticos com responsabilidade em matéria educativa até os pais dos alunos, todos parecem dispostos a considerar o professor como o principal responsável pelas múltiplas deficiências e pela degradação geral de um sistema de ensino fortemente transformado pela mudança social. Ora, mais do que responsáveis, os docentes são as primeiras vítimas. (ESTEVE, 1995: 104)

Com esta retirada do apoio ao trabalho docente, a valorização social do professor também se modificou, tornando-se menor do que antes. Como hoje o status social está 
ligado a critérios econômicos e os professores têm salários mais baixos em relação a outros profissionais com o mesmo nível de formação acadêmica, cria-se uma desvalorização social em relação ao profissional docente, ligada, entre outros fatores, a questões salariais.

Um importante fator a ser considerado é o relacionado à mudança nos conteúdos curriculares. As transformações sociais ligadas aos avanços tecnológicos, ligadas a mudanças nos processos de comunicação, de produção e circulação de informações, trazem a exigência de mudança nos currículos e conteúdos escolares. Com inúmeras possibilidades de pesquisa, de redes que possibilitam a rápida troca de informações, há um repensar do que é mais importante e significativo a ser ensinado para as novas gerações. Se estamos preparando os meninos e meninas para uma realidade social que se constrói a cada dia, que se modifica rapidamente, se estamos preparando-os para uma nova configuração social, como saber o que é melhor que eles saibam? Esta realidade traz inúmeros conflitos para os professores, abalando sua confiança nas atividades docentes que desempenham. Ao educar as novas gerações, transmitimos conteúdos considerados socialmente necessários para aquela determinada sociedade. Se falamos de outra configuração social, se falamos de uma diversidade de fontes de informação, relacionadas aos avanços na tecnologia e às mudanças nos aparatos comunicacionais e informacionais, como selecionar quais conteúdos são mais relevantes para o trabalho com as novas gerações?

Esse repensar dos conteúdos e das práticas docentes para o trabalho com esses conteúdos está intimamente ligado ao repensar dos cursos de formação inicial de docentes. As mudanças sociais afetam o cotidiano docente, trazendo implicações sobre a forma como estão pensados os cursos de professores. Belloni nos traz uma reflexão forte:

As tentativas de inovação metodológica, por exemplo, as práticas inspiradas no construtivismo, tem se chocado com a resistência dos professores que, apesar do discurso inovador ou construtivista, não transformaram em quase nada sua prática pedagógica efetiva e continuam a ser formados para repetirem velhas pedagogias, quase sempre sem novas tecnologias. (BELLONI, 2009: 92)

Formados para repetirem velhas pedagogias... Um novo cenário, com novas linguagens e os docentes formados para um cenário que não existe mais... Formados para um contexto social que já se modificou... 
Além dos fatores relacionados ao contexto social mais amplo que implicam na atividade docente, temos mudanças que estão relacionadas mais diretamente ao trabalho docente nas salas de aula.

A falta de recursos materiais e as condições de trabalho dos professores também afetam sua atividade docente. Ao mesmo tempo em que aumentaram as exigências quanto ao trabalho docente, também em função das modificações sociais, inclusive as modificações vinculadas aos avanços tecnológicos e comunicacionais, esse aumento das exigências não veio acompanhado de recursos materiais que possam colaborar na implementação das atividades necessárias ao cotidiano das escolas e de trabalho dos professores. Muitos professores continuam afirmando que só tem giz para trabalhar nas aulas. Numa sociedade em que os meninos têm a seu dispor fontes de informações diversas, em suportes cada vez mais diferenciados, onde os meninos podem tirar fotos com seu celular, podem publicar filmes na internet feitos por eles mesmos, onde podem navegar em sites diversos, temos professores somente com giz à sua disposição, exigindo bastante da sua criatividade, da sua capacidade de envolver os alunos nas propostas de ensino. Junto à falta de recursos materiais para o trabalho, o cotidiano de trabalho dos professores é marcado por um sistema com horários, normas, formas de organização do tempo e espaço, que também interpelam sua forma de trabalhar.

Outro fator a ser destacado é a mudança nas relações professor-aluno. Todo o quadro de mudanças elencado acima, trouxe mudança nas relações escolares, que estão mais conflituosas e complexas, demandando dos professores um repensar das questões relacionadas à participação dos alunos, a formas de convivência, ao trabalho com questões disciplinares. Um último fator a ser considerado é a fragmentação do trabalho do professor. Ainda em função de todas as novas demandas apresentadas acima, se exige cada vez mais dos professores, se exige uma multiplicidade de funções e desempenho de diferentes papéis, que acaba por fragmentar o trabalho do professor e levá-lo a um desgaste no cotidiano.

Todas essas mudanças sociais apresentadas impactam o trabalho dos docentes, exigindo um repensar dos processos de formação:

A mudança acelerada do contexto social influi fortemente no papel a desempenhar pelo professor no processo de ensino, embora muitos professores não tenham sabido adaptar-se a estas mudanças, nem as autoridades educativas tenham traçado estratégias de adaptação, sobretudo em nível de programas de formação de professores. (ESTEVE, 1995: 100) 
A formação de professores, em função das transformações, precisa ser repensada para que não tenhamos uma formação inicial frágil, descolada das realidades contemporâneas, que não colabore para um exercício profissional competente dos professores. Ao assumirmos que a comunicação é uma das dimensões que configura o campo cultural na atualidade e assumirmos também que a escola é produtora de cultura e produtora de comunicação social, torna-se evidente que a escola, em seus vários níveis, inclusive no nível da formação docente, precisa trazer para seu interior as discussões afeitas a esse campo cultural. Um dos papéis da escola é a construção da cidadania e a cidadania passa, nas sociedades contemporâneas, pela incorporação das tecnologias e suas linguagens, porque também por intermédio delas circula o conhecimento que está sendo produzido pela humanidade. Há uma dimensão cultural nos processos de comunicação midiática que precisa estar incluso na formação inicial de educadores. Vivemos uma relação entre comunicação, educação e uso de novas tecnologias nas sociedades contemporâneas, que deve ser debatida e compreendida em nossos ambientes escolares, principalmente nos ambientes que são formadores de formadores. Como nos coloca Orozco:

A tríade comunicação, educação e novas tecnologias resume uma das problemáticas substantivas do novo milênio. Constitui um desafio central, não só para os comunicadores e os educadores preocupados pelo avanço da tecnologia telemática e digital e suas múltiplas vinculações mútuas, mas também para a democracia e, claro, para a cultura, como processos maiores que contextualizam e condicionam a geração, circulação e consumo do conhecimento. (OROZCO, 2011: 159-160)

A escola é peça fundamental na construção cultural, na criação e recriação da cultura. A escola como peça fundamental em entender que esse campo cultural está relacionado hoje às questões comunicacionais midiáticas e que os aparatos tecnológicos interpelam nossas sociedades em diversos campos, interferindo no cotidiano das sociedades e dos indivíduos. Não se trata de termos uma escola ilhada, que se ausente das discussões do espaço e tempo no qual está inserida, do qual faz parte histórica e socialmente. Uma escola que se assuma como produtora social de comunicação, discutindo as questões colocadas pelas mídias, as questões colocadas pelos avanços tecnológicos. Uma escola como possibilidade de pensamento e reflexão.

Considerá-la como lugar onde os alunos aprendem a razão crítica para poderem atribuir significados às mensagens $\mathrm{e}$ informações recebidas das mídias, multimídias e formas de 
intervenção educativa urbana (...). A escola exercendo a função reestruturante e organizadora das informações e aportes culturais; recebidos multivariadamente, fazendo a síntese entre a cultura formal e a cultura experienciada. É necessário que a escola propicie não só o domínio de linguagens para busca da informação, mas também para a criação da informação. (LIBÂNEO, 1998:65)

Uma escola que reflita sobre as mudanças sociais e se assuma participante ativa deste quadro de mudanças, compreendendo as dinâmicas sociais. Uma educação e uma escola que "se preocupa com a interação dialética entre as pessoas e a realidade, com o desenvolvimento de suas capacidades intelectuais e da consciência social. (MACHADO, 2009: 41)

Nesse sentido, professores formados para trabalhar em escolas nessa perspectiva - emancipatória e crítica - devem estar preparados para entender não somente de novas tecnologias, de suas linguagens e possibilidades. Mas devem ser capazes de uma leitura ampla de mundo, percebendo as nuances dos processos comunicativos e as relações político ideológicas que perpassam esses mesmos processos. Propomos uma educação que possibilite muito além do trabalho com mídias, mas que pense todo o ambiente comunicacional em que vivemos e possa problematizá-lo, estimular discussões, reflexões e diálogos, envolvendo alunos, professores, comunidade em formas de participação social, com vistas à construção de qualidade de vida para todos.

.Autores como MARTÍN-BARBERO (2000) afirmam que as sociedades atuais apresentam duas dinâmicas básicas que caracterizam as mudanças pelas quais passamos: o surgimento de um novo ecossistema comunicativo, onde as relações comunicacionais estão perpassadas por novas tecnologias de comunicação e informação e onde se percebem novas sensibilidades, principalmente entre os mais jovens. Nas palavras de WOLF (1987:54): “os jovens têm mais empatia cognitiva e expressiva com as tecnologias e com os novos modos de perceber o espaço e o tempo, a velocidade e a lentidão, o próximo e o distante". A outra dinâmica das sociedades atuais é relativa aos ambientes educacionais. Podemos falar de um ambiente educacional difuso, com inúmeras informações circulando, com descentramento do sistema educativo escolar. Um dos maiores desafios que as novas formas de comunicação colocam hoje para a escola e para os professores é justamente essa possibilidade de diversificação e circulação do saber fora do ambiente escolar, para além dele, em conjunto com o outro 
desafio citado: as novas formas de perceber - e consequentemente, de aprender - das gerações mais jovens.

Os professores tem tido dificuldades em conviver com essas alterações, as quais requerem não apenas o descentramento do professor no processo de ensino-aprendizagem, como estão a exigir competências comunicativas mais aprimoradas. Se, desde sempre, as relações comunicativas são essenciais à vida em sociedade, num mundo cheio de tecnologias essa exigência é maior. (TOSCHI, 2003:117)

Some-se a esses desafios, o desafio ao qual está relacionado este trabalho, o da formação de professores. Há, ainda, uma tradição nos currículos e projetos pedagógicos dos cursos de formação inicial de docentes, que primam mais por aspectos teóricos do que por abrir espaço nos quadros curriculares para a discussão de questões práticas vivenciadas nas escolas, para a discussão de temas sociais atuais, conflitivos, que exigem novas abordagens e a construção de práticas alternativas, diferenciadas quanto aos processos de ensino aprendizagem. (GATTI e BARRETTO, 2009)

Os currículos, tanto dos cursos de formação inicial de professores quanto os currículos de nossas escolas de educação básica, ainda estão muito centrados nos saberes científicos produzidos pela humanidade e considerados centrais para a aprendizagem dos meninos e meninas. Sem desconsiderar esses saberes, há que se pensar que os saberes relativos à tecnologia - também uma produção cultural da humanidade, também conhecimento humano - são pouco discutidos, analisados, vivenciados em nossos currículos.

A tecnologia atual trouxe em seu bojo, novas formas de nos relacionarmos, novas formas de estarmos em contato com informações. Trouxe novas formas de aprendizagem. Se pensarmos que todos ensinamos em alguns momentos e aprendemos em outros, nossos processos de comunicação, inclusive comunicação escolar, tem que ser mais dialógicos, não coercitivos, processos de comunicação mais horizontalizados, onde circulem todos os saberes, todas as percepções, possibilitando diferentes formas de construção de pensamento, com diferentes e múltiplas linguagens. Podemos pensar em mediações na educação que nos possibilitem a construção de novos formatos de espaços escolares. Nas palavras de Soares:

Trata-se de um espaço de vivência pedagógica muito próximo ao imaginário da criança e do adolescente, propiciando que não apenas dominem o manejo dos novos aparelhos, mas que criem projetos para o uso social das invenções que caracterizam a era da informação. (SOARES, 2011: 48) 
Pensar em processos comunicacionais em nossos ambientes escolares que permitam vivências entre todos os sujeitos, com circulação dos diversos e diferentes saberes, na construção de relações mais autônomas e democráticas, que podem trazer perspectivas de mudanças exigidas pela nossa sociedade atual.

Nossas escolas ainda estão pautadas em modelos de comunicação verticalizados, baseados na transmissão unidirecional de mensagens, formando os professores para um cenário que, socialmente, não existe mais, o que colabora para a produção do mal estar docente, como já discutimos no capítulo anterior. Colabora para termos um retrato de escola e de professores em estado de desânimo, diante da velocidade das mudanças que interferem em suas práticas escolares cotidianas, com as quais não estão conseguindo estabelecer diálogos, propondo novas articulações e formas de trabalho.

Soares (2011) nos fala em trazer para os espaços educativos o mesmo brilho no olhar que vemos nas crianças quando estão "navegando" em sites na Internet, quando estão jogando games, quando assistem a uma produção cinematográfica que lhes permite sonhar. Podemos igualmente pensar em trazer brilho para o olhar dos professores, um brilho de quem se percebe co-criador, com potencialidade para mobilizar potencial criativo, na direção da construção de uma sociedade mais fraterna e igualitária, com melhor qualidade de vida para todos. Para pensarmos melhor a relação entre comunicação e educação, enfatizando a necessidade de estabelecermos relações mais democráticas e criativas, discutimos a seguir diferentes abordagens em processos comunicacionais e educacionais.

\subsection{Processos comunicacionais e educacionais: a relação com a formação e trabalho docente nas escolas:}

Importa não somente discutirmos a presença das novas tecnologias nas escolas, nos currículos, nos cursos de formação inicial de docentes. Importa também pensar em como estamos entendendo a relação entre comunicação e educação, em como estamos pensando a mudança que os novos aparatos tecnológicos e suas diferentes linguagens, impactam no cotidiano das atividades docentes, no dia a dia de nossas escolas e alunos em processo de formação e de construção da subjetividade. 
Para aprofundarmos essa questão, vamos, brevemente, resgatar as diferentes concepções sobre modelos comunicacionais, entrecruzando-os com modos de praticar e pensar educação escolar e pensar a recepção dos sujeitos diante das novas tecnologias e suas linguagens.

Os modelos comunicacionais historicamente produzidos, apontados por WOLF (1987), são referências pertinentes e que contribuem para estudos sobre as relações entre a comunicação e a escola. Na história das pesquisas nessa área - formuladas ao longo do século XX e que Wolf chama de teorias comunicativas - é apontada a existência de três modelos comunicacionais: modelo comunicativo informacional, modelo comunicativo semiótico-informacional e modelo semiótico-textual.

Não tenho o intuito de aprofundar o estudo sobre estes modelos, mas sim o de procurar destacar alguns de seus aspectos que se entrecruzam com modos de praticar e pensar educação escolar e a recepção dos telespectadores. Tentarei esclarecer os aspectos relevantes em cada modelo apresentado por Wolf e, a partir daí, destacar traços deles nas tendências pedagógicas, além das conservações e rupturas de posicionamentos postas em movimento nessas redes de significados.

O primeiro modelo, comunicativo informacional, também é conhecido como teoria matemática da comunicação ou modelo hipodérmico, mecanicista, do tipo “estímulo - resposta". Segundo TOSCHI (1993: 45)

\section{a origem do modelo comunicativo informacional é buscada nos trabalhos de engenharia das telecomunicações sobre a velocidade de transmissão de mensagens telegráficas, sobre a medida da quantidade de informação que objetivavam melhorar a velocidade de transmissão de mensagens.}

Em cada processo comunicativo existiria a fonte da informação, a ser transmitida por um canal, recebida e convertida em mensagem, chegando ao destinatário. Portanto, como destaca WOLF (1987: 100), a principal finalidade da teoria informacional é "fazer passar, através de um canal, o máximo de informações com o mínimo de distorção e com a máxima economia de tempo e de energia."

A preocupação desse modelo não é com o significado da mensagem, mas sim com a rapidez de transmissão da informação. Ele facilitou o estudo dos "efeitos", que tem sido, em termos de estudos sobre recepção, a abordagem mais discutida. Devido à possibilidade de quantificação, de experimentação, o modelo informacional favoreceu o estudo sobre o que a transmissão das mensagens provoca nos receptores. 
Nesse modelo funcionalista de comunicação, predomina a dualidade do pensamento cartesiano sobre a relação entre objeto e sujeito. Essa análise funcionalista da comunicação foi introduzida e expandida no Brasil, principalmente, por meio da expansão das agências norte - americanas de publicidade e dos institutos de pesquisas e de opinião pública. Privilegia-se o ângulo psicossocial no estudo do comportamento para identificar e estimular o consumo. O sujeito da comunicação é o indivíduo, mas reificado enquanto peça de um sistema.

O segundo modelo sintetizado por WOLF (1987), o semiótico-informacional, incorpora o primeiro e supera-o ao colocar as diferenças individuais como intrínsecas à comunicação. Nesse modelo, a preocupação passa a ser a transformação de um sistema por outro, ao invés apenas da transferência ou transmissão de informação. Nesse modelo,

\begin{abstract}
A mensagem significante pode ter vários significados e mesmo que existam códigos de base aceitos por todos, pode haver diferenças nos sub-códigos. É a chamada 'decodificação aberrante', que se verifica quando o destinatário faz uma interpretação das mensagens diferente das intenções do emissor e do modo como ele previa que a decodificação seria executada. (TOSCHI, 1993: 59)
\end{abstract}

Portanto, no modelo semiótico-informacional, abre-se a possibilidade de respostas diferentes ao mesmo estímulo. Passa-se a considerar como se articula o mecanismo de reconhecimento e de atribuição de sentido entre códigos do emissor e do receptor.

O terceiro modelo, semiótico-textual, incorpora, por sua vez, os dois primeiros, superando-os ao colocar que o destinatário não recebe uma única mensagem, mas muitas ao mesmo tempo, incluindo as de sua história e confrontos culturais.

O modelo semiótico-textual considera que há uma assimetria dos papéis de emissor e receptor, isto é, a falta de correspondência não se refere somente à interpretação das mensagens transmitidas, mas vai além ao entender que a troca comunicativa se constrói não só no confronto de mensagens com códigos reconhecíveis, mas se realiza na competência interpretativa dos destinatários, a qual se amplia se os conjuntos textuais, isto é, as diversas mensagens transmitidas, são textos já consumidos, isto é, formam conjunto de mensagens já reconhecidamente aceitas. (TOSCHI, 1993: 65)

Portanto, nesse terceiro modelo, a relação é histórica e cultural do receptordestinatário e do emissor-destinador. Nesse processo de construção da comunicação 
entre emissor e receptor, as informações, ideias, sentimentos são transmitidos, transformados, elaborados, sendo a codificação influenciada pelas próprias condições e diversas fontes da decodificação e da história de cada um.

Contemporaneamente, ao receptor não é reservado o lugar da passividade. Considera-se que existe uma pluralidade: os meios de comunicação não existem isolados nem as pessoas se expõem a eles isoladamente; compõem uma prática conjugada: a intermídia está na esfera da produção tanto quanto na do consumo. (SOUSA, 1995). Assim, a própria comunicação social é processo e tanto ela quanto os veículos dos quais se serve participam da construção da subjetividade.

Frequentemente, ainda, ao analisarmos TV e outras mídias eletrônicas e digitais, prevalece a redução, a tecnologia-máquina-ferramenta-veículo. Ou seja, ela é encarada como "entidade", como expressão viva do emissor-invasor.

Deveríamos trabalhar com novas categorias de análise, com a noção de cotidiano, da interação comunicação-cultura. Procurar perceber novos modos de compreender o lugar do receptor-sujeito em comunicação. Como coloca MARTÍNBARBERO (1995), o emissor e o receptor não se situam somente com relação a um canal, a um meio, porém também em relação a necessidades e problemas quanto à suas próprias vivências e histórias.

Segundo Barbosa da Silva,

$$
\begin{aligned}
& \text { a comunicação passa a ser vista como um processo que é } \\
& \text { produzido entre sujeitos ativos, culturais, históricos que } \\
& \text { possuem experiências, crenças, sentimentos, conceitos, ideias, } \\
& \text { práticas, que são captadas e reelaboradas nesse processo. Não se } \\
& \text { trata de um simples processo de "ida e volta", mas de um } \\
& \text { processo dialético de elaborações cognitivas, emotivas onde } \\
& \text { nem todas as nuances estão previstas a priori nem tão pouco são } \\
& \text { rigorosamente controláveis. (BARBOSA da SILVA 1997:7) }
\end{aligned}
$$

Também na área de educação existem pressupostos diferentes quanto ao processo de ensino-aprendizagem, à forma de selecionar e trabalhar com conteúdos, às maneiras de entender a avaliação. Esses diferentes pressupostos relacionam-se a determinadas visões de homem e de mundo. Dentre muitos estudos realizados na área educacional, trabalharei com as tendências pedagógicas apontadas por LIBÂNEO (1984). Fiz esta escolha porque o trabalho deste autor procura fazer um levantamento das tendências, baseado na prática dos professores nas escolas.

O critério que Libâneo utilizou, para estabelecer a classificação, foi a posição que cada tendência pedagógica adota em relação às finalidades sociais da escola. Assim, 
poderíamos dividir as correntes da Pedagogia em dois grandes grupos: as liberais e as progressistas.

Dentro da corrente da Pedagogia Liberal teríamos a escola conservadora, a renovada progressivista (ou escola nova) e a renovada não-diretiva. O conjunto da Pedagogia Progressista seria formado pela escola libertadora, libertária e pela pedagogia crítico - social dos conteúdos.

Assim, como destaquei ao discorrer sobre os modelos comunicacionais, não tenho por objetivo discutir profundamente cada uma dessas escolas de pensamento. Procurarei destacar os aspectos mais relevantes quanto a cada escola apresentada por Libâneo, para cruzar com aspectos dos modelos comunicacionais. Também ressalto que as duas grandes correntes e suas escolas de pensamento se interpenetram, num movimento dialético, onde ocorrem justaposições e rupturas. Considerar as escolas e suas características como puras ou mutuamente excludentes seria absurdo. Apesar da limitação da classificação, acredito que servirá como instrumento de análise para o objetivo que se pretende: perceber a relação existente entre modelos comunicacionais e modelos educacionais.

Quanto ao primeiro grande conjunto, o da Pedagogia Liberal, sintetiza, em educação, os princípios defendidos pela doutrina liberal, que procuram justificar o sistema capitalista de produção. Segundo Libâneo:

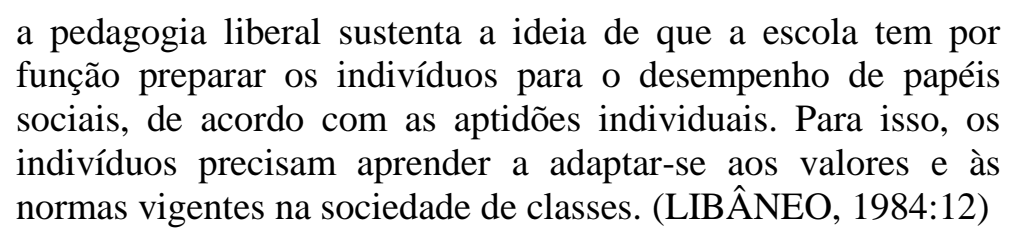

Esta corrente favorece o individualismo e a competição. Escamoteia a desigualdade social ao difundir a ideia de igualdade de oportunidades, desconsiderando a desigualdade de condições. Em sua versão conservadora, é a autoridade do professor que predomina, ocorrendo a exigência de atitude receptiva por parte dos alunos. É o professor quem transmite o saber, e este é desvinculado da realidade concreta. Para absorver o que é transmitido pelo professor, o aluno deve estar em silêncio, atento e ser disciplinado.

$\mathrm{Na}$ chamada Escola Nova, o aluno é o sujeito da aprendizagem, sendo o processo de aprendizagem mais importante do que o ensino. Segundo Libâneo, nessa concepção de pedagogia renovada, em oposição à tradicional 
o professor deve colocar o aluno em condições propícias para que, partindo de suas necessidades e estimulando os seus interesses, possa buscar por si mesmo conhecimentos e experiências. A ideia é a de que o aluno aprende melhor o que faz por si próprio. O professor incentiva, orienta, organiza as situações de aprendizagem, adequando-as às capacidades de características individuais dos alunos. (LIBÂNEO, 1991: 65)

Portanto, o professor orienta o raciocínio do aluno, para que este pense de forma independente. $\mathrm{O}$ conhecimento é transformado a partir das ações dos alunos. Apesar dos avanços em relação à pedagogia conservadora, a relação interpessoal é essencial, implicando uma prática em que o professor deve trabalhar com pequenos grupos. Para quem conhece a realidade da educação brasileira (salas de aula lotadas), sabe que isso é, senão impossível, bastante improvável!

A terceira escola de pensamento componente da Pedagogia Liberal é a renovada não-diretiva, que propõe educação centrada no aluno, sendo que o professor deve garantir um clima de relacionamento pessoal e autêntico. Deve-se favorecer um clima de auto-desenvolvimento e realização pessoal.

O segundo grande grupo, denominado Pedagogia Progressista, parte de uma análise crítica das realidades sociais, sustentando as finalidades sócio-políticas da educação. A Pedagogia Progressista Libertadora consiste na educação voltada para a conscientização da opressão, o que permitiria uma conseqüente ação transformadora. Aprender é apropriar-se da realidade concreta, das situações reais da vida, aproximando-se criticamente dessa mesma realidade. $\mathrm{Na}$ escola de pensamento libertária privilegia-se a autogestão, recusando-se qualquer forma de poder ou autoridade.

A terceira versão da pedagogia progressista, a escola crítico-social dos conteúdos, valoriza a difusão de conteúdos, entretanto, esclarece que estes devem ser concretos, indissociáveis das realidades sociais. Acredita-se que se todos tiverem acesso a um bom ensino, que seria a apropriação dos conteúdos escolares básicos, colaborar-seia com as classes populares, possibilitando-lhes igualdade social.

De uma forma geral, a tendência progressista trabalha na perspectiva da relação horizontal/dialógica entre professor e aluno, em que existe troca e construção de conhecimento nos dois pólos da relação. Os temas trabalhados têm dimensão social e política. A educação é concebida como uma das formas de transformação social, de reflexão sobre a realidade em que se está inserido, visando a mudanças. 
Estas tendências pedagógicas coexistem em nosso país, sendo possível identificá-las em diversos momentos históricos.

Assim como houve transformações/evoluções nas práticas e entendimento sobre comunicação, estas também ocorreram na área da educação. Logicamente, não se passa mecanicamente de um modelo comunicacional para outro, ou de uma tendência pedagógica para outra. Ocorre, pode-se dizer, uma justaposição em alguns momentos. Em outros, uma interpenetração ou uma superação por incorporação. Com isso, quero reafirmar que o processo de mudança de tendências comunicacionais e educacionais não é linear. É dialético. Existe conflito entre ideias diferentes, que buscam a superação, num mundo material, eivado também de conflitos, especialmente no Brasil.

Se fôssemos fazer um cruzamento das duas áreas, poderíamos dizer que ao modelo comunicativo informacional corresponderia a pedagogia liberal, em sua versão conservadora, considerando-se a passividade de um dos pólos da relação. $\mathrm{Na}$ dita pedagogia, existe predomínio da autoridade do professor, sendo o aluno mero receptor, como ocorre no modelo informacional. Neste modelo também não ocorre a preocupação com a mensagem, mas sim com a eficácia da transmissão, assim como na pedagogia conservadora desvincula-se o conhecimento da realidade concreta dos alunos e enfatiza-se a transmissão de saberes dominados pelo professor.

O segundo modelo, semiótico-informacional, corresponderia à pedagogia liberal renovada. Segundo TOSCHI (1993: 58):

o modelo semiótico-informacional, contrastando com o informacional, coloca as diferenças individuais como intrínsecas à comunicação e, por esta razão, possui certa homologia com a pedagogia liberal renovada que concebe que as diferenças individuais devem ser levadas em conta no processo educativo.

Até, pode-se dizer, que existe relação entre o modelo semiótico-informacional e a pedagogia progressista, pelo fato de considerarem essencial a relação comunicativa. Mas, como ocorre uma preocupação na pedagogia progressista com a realidade e com a situação social e histórica, podemos relacionar esta tendência mais ao modelo comunicacional semiótico-textual, o qual considera que as mensagens são transformadas e construídas no âmbito de um conjunto cultural e que, neste conjunto, os critérios de significação são diferentes. Também porque, neste terceiro modelo, o receptor e o emissor têm papel ativo, assim como o aluno e o professor são partes integrantes, ou seja, ambos são sujeitos do processo na pedagogia progressista. 
Hoje, ao considerar-se a comunicação social e a educação enquanto processos, o receptor também ocupa seu lugar de sujeito emissor e que interage com as mídias. $\mathrm{O}$ aluno e o professor, ambos receptores e emissores nos processos comunicacional e educacional, têm capacidades cognitivas e sensíveis, pluri e transculturais de elaboração e reelaboração constantes, interagindo com seu meio, transformando-o e sendo por ele transformados.

Diante das discussões que estamos fazendo, da necessidade da escola repensar seu cotidiano, da necessidade de repensarmos também a formação inicial de professores, é importante refletirmos em que modelo de comunicação e de educação estamos pautados, predominantemente, até hoje. Nas palavras de Martín-Barbero:

O modelo predominante é vertical, autoritário na relação professor-aluno e linearmente sequencial no aprendizado (...). Enquanto permanecer a verticalidade na relação docente e a sequencialidade no modelo pedagógico, não haverá tecnologia capaz de tirar a escola do autismo em que vive. Por isso, é indispensável partir dos problemas de comunicação antes de falar sobre os meios. (MARTÍN- BARBERO, 2000:52)

Pensar a relação entre comunicação e educação, pensar a relação entre a construção histórica de modelos de comunicação e modelos de educação, pode nos ajudar a pensar novas formas de trabalho nas escolas, que assumam as interfaces entre processos comunicacionais e educacionais, colaborando em processos de formação de professores que estejam em condições de promover movimentos dialógicos entre as dimensões pedagógicas e didáticas e os desafios contemporâneos trazidos pelos ecossistemas comunicativos. Pode colaborar para o "empoderamento das pessoas para se expressarem e, portanto, para se apropriarem dos recursos midiáticos, a partir do seu ponto de vista e dos seus próprios projetos e interesses. (MACHADO, 2009: 34)

Este entrecruzamento de modelos comunicacionais e educacionais também pode nos ajudar a repensar o formato de nossos cursos de formação de professores, em função da realidade cultural que estamos vivendo hoje, perpassada por transformações tecnológicas e comunicacionais que trazem novas demandas para as instituições sociais, inclusive para as escolas e faculdades. Pensarmos em uma formação de professores

Voltada para a dialogicidade educomunicativa, em condições de prever formação teórica e prática para que as novas gerações tenham condições não apenas de ler criticamente o mundo dos meios de comunicação, mas, também, de promover as próprias formas de expressão (...), construindo espaços de cidadania pelo uso comunitário e participativo dos recursos da comunicação e da informação. (SOARES, 2011: 37) 
Pensar formatos de cursos de formação inicial de professores pautados na dialogicidade, no reconhecimento da alteridade dos sujeitos, pautados na possibilidade do trabalho com novas linguagens e saberes, do que é necessário trabalhar com as novas gerações, para que possam ter posturas reflexivas e criativas. Podemos repensar os modelos de comunicação que estamos vivenciando, introduzindo nas escolas e nos processos educacionais e escolares, formas de comunicação mais descentralizadas, horizontais, que aproximem professores e alunos, que permitam trocas efetivas de saberes e fazeres, que permitam que todos os integrantes do processo sejam, ao mesmo tempo, emissores e receptores, que todos tenham autoria e produzam cultura, criando e recriando significados diante do mundo em que vivem. Se nossas crianças e jovens constituem suas subjetividades em relação com os novos aparatos tecnológicos, em processos comunicacionais mediados por novas tecnologias, se aprendem de formas diferentes, nós, enquanto professores, enquanto formadores daqueles que serão formadores, temos que pensar essas novas construções e aproximar o diálogo entre essas duas áreas envolvidas nos processos de aprendizagem e constituição dos sujeitos nas sociedades contemporâneas, a área de educação e a área de comunicação.

A diversificação e circulação do saber fora da escola, para além daquele que acontece na escola, é um desafio para os docentes, um desafio para os cursos de formação de docentes. Os futuros docentes, dentre outras funções, precisam estar preparados para habilidades comunicativas, inclusive as perpassadas pelas tecnologias e suas novas formas de linguagem.

Ao pensarmos em como estão nossos quadros curriculares nos cursos de formação inicial de professores, vemos a fragilidade desta formação no que tange a questões comunicacionais, a questões midiáticas. Retomemos os dados apresentados no capítulo anterior. Diante de quadros curriculares com, aproximadamente, 3200 horas, 80 ou 120 horas são destinadas a uma discussão sobre as questões educomunicacionais! Não se trata de termos somente uma carga horária maior para a discussão de questões relacionadas à interface entre educação e comunicação - ainda que isto também seja necessário - mas de tratarmos a comunicação de forma diferente. Assumi-la como uma área estratégica na nova configuração social, como interlocutora direta das questões culturais, que acabam por nos constituir como pessoas. Trata-se de assumirmos, como escola, uma posição de produtores de cultura e não de meros receptores de cultura, 
transmissores de conteúdos já prontos e estabelecidos socialmente. Trata-se de, como escola e como professores, nos assumirmos como produtores sociais de comunicação, capazes de elaborar novos significados diante dos artefatos culturais com os quais convivemos, de ressignificar representações sociais já dadas. Trata-se de estarmos prontos a conversar com novas linguagens, articulando-as a saberes e linguagens já existentes; trabalharmos com novos suportes, criando e recriando possibilidades, entendendo que o uso e as potencialidades da tecnologia também depende de nossas escolhas, de nossas vontades políticas. A forma como vamos trabalhar com as tecnologias em nossas aulas, a forma como vamos mediá-las, depende de como entendemos o ser humano, como vemos o mundo e as relações entre as pessoas. Tratase de formarmos professores capazes de lidar com as tecnologias comunicacionais e toda sua polissemia, redimensionando seu papel de comunicadores sócio-históricocultural no mundo em que vivem. Segundo BATISTA (2005), não são as tecnologias, os meios de comunicação em si, que exclusivamente irão transformar a relação pedagógica. A tecnologia tanto pode acentuar uma relação conservadora como pode contribuir para uma visão mais progressista. Depende do uso que façamos dela e também de conseguirmos entender com quais visões de mundo e de ser humano ela está comprometida.

Nas palavras de Moran:

O reencantamento, enfim, não reside principalmente nas tecnologias - cada vez mais sedutoras - mas em nós mesmos, na capacidade em tornar-nos pessoas plenas, num mundo em grandes mudanças e que nos solicita a um consumismo devorador e pernicioso. É maravilhoso crescer, evoluir, comunicar-se plenamente com tantas tecnologias de apoio. É frustrante, por outro lado, constatar que muitos só utilizam essas tecnologias nas suas dimensões mais superficiais, alienantes ou autoritárias. O reencantamento, em grande parte, vai depender de nós. (MORAN, 1994:26)

Conforme BATISTA (2005), a produção sócio histórica de comunicação com mídias, que inclua transmissões, mas, sobretudo, transformações e construções significativas no conjunto cultural das pessoas participantes, é um reencantamento cuja prática é necessária na formação inicial e contínua de professores em nosso país.

Para pensarmos em como estamos lidando com esta questão, a produção sócio histórica de comunicação com mídias, que pode e deve estar presente nos cursos de formação docente, passamos a analisar as ementas das disciplinas relacionadas a 
questões educomunicacionais dos cursos de formação inicial de professores da cidade de Santos.

\subsection{O que retratam as ementas das disciplinas relacionadas à área de comunicação nos cursos de formação inicial de docentes}

Ao considerarmos os cursos de formação inicial de docentes o lócus por excelência de debate das questões relativas às nossas escolas contemporâneas, e também assumirmos a importância nestas sociedades contemporâneas, onde estão inseridas as escolas, da dimensão comunicacional midiática, torna-se evidente que os cursos de formação devem discutir estas mesmas questões comunicacionais em sua interface com questões educacionais, em sua relação com os cotidianos das crianças e jovens que estão nas escolas, assumindo seu papel de lugar de formação e de produção social da comunicação.

No capítulo anterior, apresentamos o espaço - em termos de carga horáriadedicado a assuntos relacionados à comunicação em sua interface com educação, nos quadros curriculares dos seis cursos de Pedagogia da cidade de Santos, local escolhido para realização desta pesquisa. Nesses quadros curriculares, constatamos, diante da carga horária total do curso, a pouca quantidade de horas destinada ao tema da comunicação em suas interfaces com questões educacionais e escolares.

Com a discussão realizada que vimos apresentando, sobre a importância das questões comunicacionais nos processos de formação de professores, queremos apresentar uma reflexão sobre as ementas das disciplinas que, de forma mais direta, fazem esta interlocução nos cursos de formação, para pensarmos em como, efetivamente, vem se construindo a relação entre comunicação e educação na formação inicial de professores na cidade de Santos.

\subsubsection{Refletindo sobre as ementas e propostas das disciplinas:}

A cidade de Santos conta com seis cursos de Pedagogia, sendo dois oferecidos por centros universitários e quatro por universidades, sendo todas instituições privadas. Discutiremos as ementas e propostas das disciplinas relacionando-as aos cursos de 
Pedagogia, ressaltando que não nos interessa o que cada faculdade está fazendo, de forma isolada, mas como está colocada a discussão das questões referentes à educação e comunicação, pensando a formação oferecida em relação à prática pedagógica dos docentes nas escolas, após seu período inicial de formação, um dos pontos essenciais deste estudo.

De forma geral, os cursos analisados oferecem disciplinas que oscilam entre duas denominações: "Tecnologias Aplicadas à Educação" e "Comunicação, Educação e Novas Tecnologias". Em alguns cursos aparece a disciplina "Informática Aplicada à Educação". Os quadros curriculares completos podem ser conferidos nos anexos A, B, C, D, E e F.

Nas ementas é recorrente o uso das palavras "recursos" e "técnicas" ao tratar das novas tecnologias. Em geral, as mídias, como TV, computadores, internet são considerados recursos de apoio ao professor e aos processos de ensino-aprendizagem, ferramentas que podem colaborar no desenvolvimento das atividades trabalhadas nas aulas. Nas ementas não aparece a perspectiva da escola como produtora social de comunicação, com possibilidades de colaborar na criação e recriação de significados construídos também por alunos e professores, enquanto sujeitos comunicacionais.

A utilização da palavra "tecnologia" também é recorrente nas diversas ementas, associada à ideia de implementação de tecnologia ou de desenvolvimento das mesmas e ainda de apropriação das tecnologias ao processo de ensino-aprendizagem.

Vejamos a oferta das disciplinas, ementas e cargas horárias na tabela a seguir:

Tabela 1. Disciplinas ofertadas na interface entre educação e comunicação.

\begin{tabular}{|c|c|c|c|}
\hline $\begin{array}{l}\text { Instituições } \\
\text { Formadoras }\end{array}$ & Disciplinas oferecidas & Ementas das disciplinas & $\begin{array}{l}\text { Carga } \\
\text { Horária }\end{array}$ \\
\hline UNILUS & $\begin{array}{lcl}1^{\circ} . & \text { Semestre: } & \text { Tecnologias } \\
\text { aplicadas à educação } & \end{array}$ & $\begin{array}{l}\text { Paradigmas científicos e sua influência na } \\
\text { concepção de tecnologia aplicada à educação. O } \\
\text { uso de recursos tecnológicos na educação como } \\
\text { estratégias de intervenção e mediação nos } \\
\text { processos de ensino e aprendizagem. } \\
\text { Potencialidades e limites do uso das TICs. }\end{array}$ & $80 \mathrm{~h}$ \\
\hline UNIMES & $\begin{array}{l}1^{\circ} . \text { Ano: Comunicação, educação } \\
\text { e tecnologias }\end{array}$ & 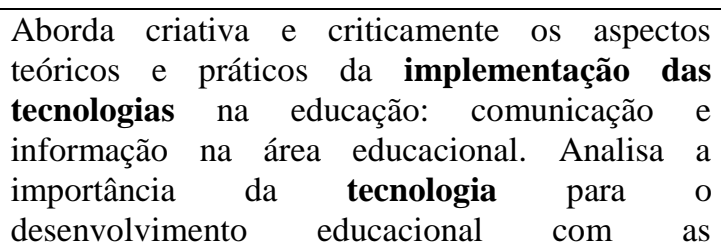 & $80 \mathrm{~h}$ \\
\hline
\end{tabular}




\begin{tabular}{|c|c|c|c|}
\hline & & $\begin{array}{l}\text { possibilidades inesgotáveis de pesquisa através de } \\
\text { um dos recursos telemáticos (Internet) e estuda o } \\
\text { potencial do computador como ferramenta } \\
\text { educacional. Trabalha com o conceito de } \\
\text { aprendizagem colaborativa entre as áreas do saber } \\
\text { pedagógico e técnico. Focaliza o processo de } \\
\text { auto-aprendizagem e interaprendizagem e a } \\
\text { importância da mediação pedagógica presencial e } \\
\text { à distância }\end{array}$ & \\
\hline UNIMONTE & $\begin{array}{l}8^{\circ} . \quad \text { Semestre: } \\
\text { tecnologias }\end{array}$ & $\begin{array}{l}\text { Reflexões sobre a produção de comunicação e de } \\
\text { informação, com ênfase nas novas tecnologias e } \\
\text { na dinâmica das transformaçães na escola e na } \\
\text { educação em geral. Práticas de educação e de } \\
\text { comunicação como responsáveis articuladoras } \\
\text { entre espaços virtuais e ambientes geográficos } \\
\text { atuais (cidades, comunidades, culturas locais) de } \\
\text { vida humana. Análise e a criação de novos } \\
\text { processos pedagógicos através de novas } \\
\text { tecnologias informatizadas. A inclusão digital. }\end{array}$ & $80 \mathrm{~h}$ \\
\hline UNIP & $\begin{array}{l}\text { Didática para o ensino a distância } \\
\text { Informática: tecnologias aplicadas } \\
\text { à educação }\end{array}$ & $\begin{array}{l}\text { Concepções atuais e procedimentos pedagógicos } \\
\text { que reorientam a didática e a formação do } \\
\text { professor nos dias de hoje. Mediação da didática } \\
\text { no uso de novas tecnologias despertando atitudes } \\
\text { de aprendizagem mais complexas e significativas. } \\
\text { O ensino a distância. Incorporação e aplicação } \\
\text { dessas novas tendências e desafios pedagógicos } \\
\text { na era tecnológica. } \\
\text { Análises teóricas e práticas que permitam ao } \\
\text { aluno elaborar e avaliar estratégias para educação } \\
\text { atual na sociedade tecnológica e informatizada. } \\
\text { Oferecimento de subsídios ao aluno para uma } \\
\text { prática pedagógica consciente, que integre } \\
\text { aspectos tecnológicos aos socioculturais de sua } \\
\text { comunidade escolar. Vivências e explorações dos } \\
\text { recursos da linguagem informatizada em } \\
\text { situações de ensino e de aprendizagem. }\end{array}$ & $36 \mathrm{~h}$ \\
\hline UNISANTA & $\begin{array}{l}1^{\circ} \text {. Semestre: } \\
\text { Tecnologias I }\end{array}$ & $\begin{array}{l}\text { A sociedade digital e a educação. Concepção e } \\
\text { histórico da informática educativa. Conhecimento } \\
\text { e avaliação de software e portais educacionais. A } \\
\text { informática como recurso educacional. } \\
\text { Concepçães sobre tecnologias e inteligências. } \\
\text { Tecnologia educacional: pressupostos conceituais } \\
\text { e filosóficos; relação; aprendizagem, tecnologia e } \\
\text { educação a distância; recursos de ensino } \\
\text { (audiovisuais). } \\
\text { Novas tecnologias educacionais: informática, } \\
\text { softwares, internet, outros; dinamização da } \\
\text { aprendizagem: educação presencial, educação à } \\
\text { distância e de novas tendências no uso do } \\
\text { computador; técnicas de utilização das diversas } \\
\text { tecnologias da educação. }\end{array}$ & $36 \mathrm{~h}$ \\
\hline \multirow[t]{2}{*}{ UNISANTOS } & $\begin{array}{l}3^{\circ} . \quad \text { Semestre: } \quad \text { Gestão da } \\
\text { Informação I }\end{array}$ & $\begin{array}{l}\text { Sociedade contemporânea e } \text { os efeitos } \\
\text { revoluçãa tecnológica na comunicação e } \\
\text { informação. Visão reflexiva e crítica acerca da } \\
\text { apropriação das tecnologias no processo de } \\
\text { ensino-aprendizagem. }\end{array}$ & $34 \mathrm{~h}$ \\
\hline & $\begin{array}{l}4^{\circ} . \quad \text { Semestre: } \\
\text { Informação II }\end{array}$ & $\begin{array}{l}\text { Mediação entre a educação e a tecnologia - mídia } \\
\text { através da competência midiática. Visão crítica e }\end{array}$ & $34 \mathrm{~h}$ \\
\hline
\end{tabular}


Fonte: Ementas relativas às matrizes curriculares dos cursos de Pedagogia de Santos.

Perceba-se que não há, em geral, nas ementas, referência a uma nova forma de linguagem apresentada nas e pelas mídias, tampouco há referência a transformações culturais articuladas às transformações tecnológicas. Ainda que apareça a questão da apropriação das tecnologias aos processos de ensino-apredizagem, não aparece explicitamente a importância da apropriação aos saberes dos professores, nem o impacto que as transformações tecnológicas e comunicacionais estão causando nas formas de aprender e socializar-se das crianças.

As ementas parecem indicar uma insistência na aplicação da técnica na educação formal, na ideia de incorporar mudanças tecnológicas que possam desenvolver de melhor forma a aprendizagem nas escolas. Aliás, a palavra escola está praticamente ausente das ementas, com exceção da instituição UNIMONTE, que fala sobre a dinâmica das transformações na escola e na educação em geral e da UNIP, que cita comunidade escolar. Conforme já discutimos no capítulo dois, há uma ausência da explicitação das questões escolares cotidianas nas ementas das disciplinas, no contexto dos quadros curriculares dos cursos de formação inicial de professores no Brasil, conforme pesquisa realizada por GATTI E BARRETO (2009).

As discussões propostas nas ementas ficam muito aquém do necessário para a formação de professores no contexto atual. Não estamos mais falando de recursos ou simplesmente novos suportes. Nas palavras de REZENDE E FUSARI:

...é preciso reformular noções pouco desenvolvidas, que muitos professores ainda mantêm (por causa da formação que recebem) a respeito de "recursos audiovisuais" e que aparecem em seus planejamentos, planos de curso, em sua didática, em suas práticas de aulas com seus alunos. As mídias (meios de comunicação) integrantes da comunicação que fazemos e pensamos ao longo da educação escolar não podem mais ser considerados apenas "recursos audiovisuais". Além de auxílios, ajudas, socorros sonoros, icônicos, verbais, dos quais nos valemos para trazer à lembrança, à imaginação, à discussão os assuntos tratados em aulas, as mídias são importantes componentes articulados ao complexo conjunto comunicacional que caracteriza a educação escolar. (REZENDE e FUSARI, 1992: 105)

Estamos falando, no campo da interface entre educação e comunicação, no campo da educomunicação, de complexas articulações em nossos processos 
comunicacionais e escolares, falando de novas formas de linguagem que exigem outras habilidades comunicativas dos professores em seu cotidiano docente. Não podemos reduzir a discussão a um mero tecnicismo. Como coloca Soares: "o universo da comunicação representa, na contemporaneidade, um mundo de cultura que jamais poderia ser reduzido a um conjunto de ferramentas." (SOARES, 2011: 19-20)

Os professores precisam aproximar-se e apropriar-se da discussão - uma vez que em muitos momentos ficam excluídos dos processos de debate e decisão - sobre uma nova configuração social, a nos exigir uma articulação entre as áreas de comunicação e educação, que possa ampliar o diálogo. Não basta formar os professores para explorar recursos ou utilizar ferramentas em suas aulas. Esta discussão fica reduzida a uma dimensão meramente técnica, que não permite um debate sobre a comunicação como constituidora do campo cultural onde ocorrem os processos de formação de educadores.

Os cursos de formação podem e precisam discutir novos papéis para a escola:

A escola, em nova perspectiva, já não seria o centro depositário do conhecimento e do saber, mas teria que se transformar em centro de reconhecimento e articulação de múltiplos conhecimentos e informações que circulam usualmente, para orientar os educandos sobre como associá-los para seus fins de aprendizado. (OROZCO, 2011: 171)

As disciplinas que discutem aspectos da relação entre comunicação e educação poderiam apresentar uma reflexão sobre como articular múltiplos conhecimentos e informações, sobre como trabalhar com novas linguagens. Sair de um reducionismo técnico para assumir novos cenários sociais e comunicacionais impactando a atividade docente e o cotidiano escolar.

A ideia de "aplicar os recursos", como aparece em uma das ementas da Instituição UNILUS, também merece uma reflexão. A palavra “aplicar" traz uma noção um pouco positivista, no sentido de que parece algo externo, que precisa ser colocado no processo de ensino aprendizagem. Como se tivéssemos uma descoberta, algo que merece ser inserido na escola. A noção do trabalho com mídias e suas novas formas de linguagem e possibilidades de criação e experimentação está mais afeita a palavras como articular, impactar, no sentido de pensar mudanças, de pensar novas formas de relação entre os processos de comunicação e mídias e as realidades educacionais e escolares.

Nos objetivos apresentados nos planos de ensino das disciplinas, também aparece, de forma recorrente, a palavra recursos. 
"Conhecer os diferentes recursos e técnicas e desenvolver a visão crítica e habilidade na aplicação desses recursos e técnicas como instrumento de apoio ao professor." (objetivos da disciplina Tecnologias aplicadas à educação - Instituição UNILUS)

Há uma insistência na utilização das expressões "recursos" e "técnicas", o que nos dá uma indicação do que vem sendo discutido nas disciplinas afeitas à relação entre comunicação e educação, onde o trabalho aparece focado na noção de recursos e instrumentos, não havendo realce em relação à criticidade dos processos e produtos comunicacionais. A compreensão, trabalhada nos cursos de formação inicial de professores, ainda é da TV, do computador, como recursos que devem apoiar o trabalho docente. É preciso avançar nesta discussão, considerando as mídias como artefatos culturais, com linguagens próprias, que exigem abordagens específicas quanto às mediações a serem exercidas por docentes, em escolas. Evoluir para o que FISCHER (2006) nos alerta, ou seja, a necessidade de tratar os meios de comunicação como produção cultural. Embora a autora nos alerte de forma mais específica sobre a TV, podemos pensar a sua fala em relação a todas as mídias:

Queremos tratar da TV como criação, como produção cultural que nos oferece uma série de possibilidades de expressão audiovisual, de comunicação de sentimentos, ideias, indagações, informações; ao mesmo tempo, desejamos fazer desse estudo da TV uma forma de pensar os problemas, as possibilidades e os impasses da educação na contemporaneidade - fortemente marcados por alguns sintomas culturais, relacionados às mudanças tecnológicas nas diferentes práticas de comunicação e de informação de nosso tempo. Há, portanto, um cruzamento básico aí, entre uma forma de expressão cultural, própria do nosso tempo, e modos de aprender e de ensinar, certamente alterados justamente pela existência desse e de outros meios de comunicação e informação. (FISCHER, 2006: 16)

Pensar a educação na contemporaneidade, numa cultura marcada pelas transformações tecnológicas nas práticas de comunicação, que estão articuladas a novas formas de aprender e ensinar, relacionadas, portanto, a novas formas de pensarmos a formação de educadores. Pensar a formação de docentes integrada às mídias "para tentar fazer com que esses participantes conheçam-se, instrumentalizem-se, reassumamse como comunicadores e como receptores mais conscientes e mais atuantes". (REZENDE E FUSARI, 1996: 187) 
A formação inicial de professores precisa garantir em seus currículos a discussão a respeito da produção social da comunicação com mídias, comunicação com suportes diferentes e convergentes entre si, numa multiplicidade de linguagens e de construção de sentidos.

As possibilidades tecnológicas nas sociedades contemporâneas permitem pensar novos paradigmas em relação não só à comunicação, mas também em relação à educação. Não há como trabalhar em nossos cursos de formação de docentes, que depois trabalharão nas escolas, seguindo - na maior parte das vezes - o seu trajeto de formação, somente na perspectiva de transmissão de conteúdos, de modelos comunicativos e educacionais pautados em unidirecionalidade. As transformações tecnológicas nos permitem hoje, além da transmissão, experimentação. Diante das mídias atuais, diante da tela da TV digital, da tela do computador, da tela dos celulares, podemos experimentar novas produções, novas combinações, utilizando diferentes linguagens. Não precisamos esperar pelas informações. A um comando, a um clique numa tecla, podemos buscar o que mais nos interessa. Podemos usar mais nossa criatividade, arriscando, navegando, sendo também autores.

Este é o campo cultural em que estamos todos imersos: os professores, formadores dos formadores, os professores em formação, os alunos nas escolas. Todos imersos numa nova configuração social atravessada pela tecnologia.

Desse modo, uma instituição importante como a escola passa a
fazer parte, também ela, dessa ordem no interior da qual os
meios de comunicação ganham, para lembrar Jesus Martin-
Barbero, dimensão estratégica (...). Reconhecer o fato segundo
o qual a produção do discurso educativo formal, com os seus
agentes, ritos, procedimentos, não consegue ser mais entendida
ou operada fora da ambiência ampla desse campo social
midiático. (CITELLI, 2010:24)

Não temos mais como não pensar a escola, como não pensar a formação de professores senão articulada a esse campo social midiático. Este novo âmbito social, estes novos cenários nos colocam desafios para pensarmos a educação, a formação docente e novas possibilidades de intervenção pedagógica. 


\subsection{PENSANdo NOVOS CENÁRIOS PARA A EDUCAÇÃo E A FORMAÇÃO DE PROFESSORES}

Um primeiro cenário a ser pensado é da sensibilização social sobre as relações e implicações entre o sistema midiático e a educação. Este cenário nos convoca a uma cultura de educomunicação. Não somente uma compreensão da inclusão instrumental, técnica, mas um repensar das relações entre comunicação e educação.

Há algumas questões que precisamos enfrentar enquanto educadores: quais transformações no sistema escolar são necessárias para incorporar todo potencial tecnológico atual? Como implantar novas pedagogias para o uso das telas com as quais convivemos - TV, celular, computador, etc?

Ainda temos que considerar que as formas de aprendizagem passam por modificações:

O uso fluente e especializado dos recursos de comunicação tem modificado alguns conceitos de aprendizagem, dando destaque a uma dinâmica em que o estudante demonstra maior autonomia para a experimentação, o improviso e a autoexpressão. Nesse sentido, a tecnologia se torna uma aliada do educador interessado em sintonizar-se com o novo contexto cultural vivido pela juventude. (SOARES, 2011: 29)

Existe uma resistência por parte dos educadores quanto às transformações em curso, não só quanto ao possível uso pedagógico das tecnologias, mas ao entendimento mais geral das interfaces na relação entre educação e comunicação. "Essa questão envolve, pois, um enorme esforço de formação do magistério tendo em vista as novas demandas sociais colocadas à escola.” (CITELLI, 2004: 208) Há um desafio quanto a entender a legitimidade educativa das novas mídias, nas interações com nossos alunos e conosco mesmo.

Esta compreensão nos leva a outro cenário: das alfabetizações múltiplas dos estudantes e dos docentes. A educação precisa ser relacionada aos meios e às tecnologias, estruturantes da sociedade atual. 
Temos que manejar diferentes códigos e gramáticas ${ }^{13}$ para entender o que vemos. Temos que entender efeitos especiais, imbricações de gênero. Necessitamos de uma alfabetização ampla, de compreensão de todo o processo de produção e circulação das mensagens. Há lógicas de funcionamento com as quais não estamos acostumados, pois nos acostumamos a pensamentos expostos em livros impressos, sequenciais, lineares. As alfabetizações a que estamos desafiados são de muita complexidade, para além dos nossos letramentos habituais. Este é um ponto importante a ser considerado nos cursos de formação de professores.

Nas palavras de Orozco:

La convergencia tecnológica que actualmente multiplica las combinaciones de formatos, lenguajes y estéticas en las diversas pantallas abre nuevos escenarios y posibilidades que a su vez contribuyen a facilitar otros modos de interacción comunicativa a sus audiencias. (OROZCO, 2009:3)

Importante destacar a predominância ainda, mesmo com os avanços de outras mídias, da TV. Estamos num processo de transição para outras mídias, com as quais temos interatividade, tais como I-pod, celular, internet. Estamos mudando paulatinamente e incorporando à tela da TV, outras telas. Entretanto, a tela principal, a mídia principal em termos de interação, de processos de emissão e recepção, ainda é a tela da TV. A transformação atual, com o desenvolvimento de outras mídias atinge uma minoria das populações. Em países latinos americanos, como México e Brasil, se falaria em $35 \%$ hoje, em termos de acesso da população às novas mídias. (Instituto Nacional de Estatística do México - INEGI, 2009; Instituto Brasileiro de Geografia e Estatística IBGE, 2009). Estatisticamente falando, $100 \%$ de nossas populações têm acesso a TV. Assistir TV é um hábito cotidiano, que faz parte do dia-a-dia de países como o Brasil. Infelizmente, não há acesso assim a todas as telas presentes na contemporaneidade. Esta situação está relacionada à distribuição desigual da riqueza dos países, com concentração de renda em algumas classes sociais, em detrimento de outras. Por isso, não podemos perder de vista em qual terreno social e político estamos ao falar da transição que vemos em relação às mídias.

Diante deste cenário de transformação tecnológica, de novos formatos, de novas telas, que nos exigem novas competências comunicativas, há a necessidade de criarmos projetos, inclusive fora da escola, para darmos conta dessa situação da necessidade de

\footnotetext{
${ }^{13}$ Orozco (2009) utiliza o termo ao falar de novos cenários para educação, que exigem trabalho com as novas linguagens das mídias, portanto manejo de códigos e gramáticas diferenciados.
} 
alfabetização e letramento em múltiplas linguagens. Desenvolver habilidades para ler e escrever no novo mundo em que também somos emissores e podemos expressar nossas próprias mensagens, num sistema complexo de redes.

Todas essas mudanças nos fazem refletir sobre a produção de novas aprendizagens, no contexto que podemos chamar de novas educações e novos processos de formação de professores, aprendizagens realizadas com o uso dos meios e das tecnologias de informação e comunicação, numa nova ambiência cultural e social. Podemos dizer que hoje há uma exigência para a educação para a interatividade, para a percepção de mudança que os meios trazem aos nossos cotidianos, inclusive os cotidianos escolares.

Se pensarmos em nossa realidade de docentes, veremos que ainda produzimos pouco: temos poucas páginas na Internet, poucos blogs, que são formas de comunicação que vem se estabelecendo a cada dia com mais propriedade em nossa sociedade, principalmente entre as gerações mais jovens. É importante que entendamos o potencial da interatividade e desenvolvamos a nossa, como educadores, como aqueles que podem, de certa maneira, apresentar alternativas aos que estão em processo de formação.

Esta é uma aprendizagem, relacionada à interatividade, que nossas sociedades ainda estão realizando e que a escola pode e deve participar, como produtora social de comunicação, muito mais do que como simples receptora de conteúdos já prontos e estabelecidos.

As escolas, as universidades, os cursos de educação e também os de comunicação podem ser locais privilegiados para que experimentemos todas as possibilidades técnicas e de linguagens diversas dos meios, desenvolvendo outras habilidades, importantes para o mundo atual e as relações humanas que estabelecemos.

Pensar em uma escola que não se restrinja ao uso de códigos verbais, mas que também utilize imagens, sons, múltiplas linguagens, na polissemia tão diversa e conflitante da sociedade atual. Enfim, aproveitar todo esse mundo de possibilidades que a tecnologia também nos proporciona. Há formas de trabalho que a tecnologia facilita, até de forma mais lúdica, criativa. Como professores, podemos conseguir melhores resultados, desafiando os estudantes, fazendo com que queiram buscar mais. Podemos dizer que as novas educações, postas hoje, exigem maior interatividade de todos os envolvidos no processo. 
Importante destacar que não é só uma interatividade na concepção mais instrumental. É também uma interatividade com as diferentes telas com as quais temos contato, manejando-as, explorando-as, criando novas possibilidades, num processo humano, de transformação, de criação, de ousadia, de busca do novo.

OROZCO (2009) chama esse processo de uma criação comunicativa própria, uma apropriação das tecnologias, das telas para expressões comunicativas inovadoras.

Outro desafio para a educação é perceber a importância da mediação, da necessidade de problematização e aproveitamento de aprendizagens extra-escolares por parte da escola, num processo de reconversão educativa, como enfatiza OROZCO (2009).

Essa já é uma estratégia pedagógica, que começou a ser usada antes do advento das últimas e novas telas. Educomunicadores, preocupados com a formação de audiência crítica, já usavam estas estratégias, de reconversão do que está produzido fora da escola, pela mídia, para objetivos e necessidades educacionais escolares.

Podemos aproveitar produtos da TV, produtos veiculados em inúmeros sites e blogs, para estudar valores, discutir modelos de ser humano que essas mídias nos apresentam. Essa reconversão exige dos educadores uso da criatividade, de não ter medo de experienciar o novo, estabelecendo diálogos entre a comunicação e a educação.

Essa reconversão educativa é um primeiro passo para que possamos desenvolver um cenário de experimentação e desenho de novas didáticas, de novas formas de ensino e aprendizagem, que é uma forma de investigação educativa participativa. Educadores que se percebem e se assumem como investigadores, em pesquisas cotidianas, sobre e na sua própria prática docente. Esses processos investigativos colaboram nos processos de ensino, trazendo novas perspectivas. Perceber que a investigação é uma ferramenta de aprendizagem, tanto para os docentes como para os discentes.

As novas mídias também nos levam a refletir sobre o conjunto do que vemos, o que alguns autores vêm chamando de ecossistema comunicacional e educativo. Estamos inseridos nestes ecossistemas e precisamos desenvolver habilidades para a construção de uma cidadania comunicativa.

Num mundo midiático como o nosso, com uma presença constante e cotidiana dos meios de comunicação e informação, não podemos mais entender a cidadania fora das nossas interações com os meios. Se assumirmos que os meios também têm uma pedagogia, que também ensinam, têm intencionalidade, que de certa forma têm um 
currículo próprio, precisamos dialogar com essas ideias e intenções, expressas pelos meios de comunicação. Mesmo que nos eduquem sem a intenção explícita, nos apresentam jeitos de ser e estar no mundo, nos apresentam jeitos de ser cidadão. Orozco (2009) nos lembra que "en la época actual, la producción de identidades pasa necesariamente por las pantallas." (OROZCO, 2009: 10)

Nos meios de comunicação, vemos modelos de comportamento, vemos os direitos dos outros, os nossos direitos próprios. Estamos aprendendo com as telas, onde estão colocadas as representações sociais, nas telenovelas, nos telejornais, nos desenhos animados, nas propagandas, nos diversos artefatos culturais. Aprendemos a comportarmo-nos como amantes, como amigos, como pais, como professores, como consumidores. Aprendemos a ser cidadãos ou não aprendemos.

Portanto, uma responsabilidade social da escola, dos educadores, está em desenvolver nossa percepção de cidadania também conformada pelos meios de comunicação e assumir posicionamentos de diálogo, de intercâmbios, de análise crítica, de possibilidade de novas produções, exercendo realmente uma postura cidadã.

OROZCO (2009) alerta para outro cenário, que seria o da observação midiática. Estarmos atentos ao que acontece no ecossistema comunicativo, com observação e monitoramento dos programas. Conhecer a programação veiculada na tela da TV, as representações sociais apresentadas nos sites, conhecer as produções postadas nos blogs, pode nos ajudar a pensar formas de estabelecer relações com a educação, a criar possibilidades, a estabelecer diálogos, colaborando para que nossos alunos desenvolvam criticidade diante das produções midiáticas com as quais tem contato cotidianamente.

O cenário atual da comunicação, dos avanços tecnológicos, nos pede ousadia. É necessário ousar, usar todas as linguagens, perceber a complexidade do mundo atual, para criarmos e recriarmos constantemente nossos espaços. Formar professores mediadores, que busquem alternativas e possam criar, vislumbrando o novo, na construção das mudanças, da reinvenção eterna do nosso mundo. São necessárias novas educações, num sentido plural, que assuma a diversidade, para novos contextos e discursos em que somos construídos todos os dias como cidadãos, como educadores, como seres humanos.

É necessário, sobretudo, que o sistema escolar incorpore, fortemente, a ideia de que existe uma permanente luta pela construção das hegemonias discursivas. Se os media prosseguem tão célere e tranquilamente ampliando a sua força constituidora dos espaços públicos, é urgente que a educação 
formal aumente o som de sua orquestra, caso deseje continuar levando público às salas de concerto. (CITELLI, 2010: 25)

Uma formação docente que assuma a luta que existe socialmente pela construção de significados, em discursos diversos a nos interpelar todos os dias, discursos veiculados, principalmente, pelas mídias.

Diante desta explicitação de novos cenários e desafios a nos convocar, como estão nossas práticas pedagógicas em salas de aula nas escolas? Como nossos cursos de formação de professores estão preparando - ou não - para o trabalho docente cotidiano, numa sociedade midiática?

Para refletir sobre estas questões, fomos às escolas e dialogamos com professores da rede pública municipal de Santos. No próximo capítulo, apresento estes diálogos e reflexões. 


\section{CAPÍTULO 4. FORMAÇÃO DE PROFESSORES E PRÁTICAS DOCENTES: OS DADOS EM ANÁLISE}

Este capítulo apresenta as análises e reflexões quanto às respostas aos questionários aplicados a professores de escolas públicas municipais de Santos. Uma vez que a preocupação desta pesquisa é com a formação inicial de professores em sua relação com a sociedade midiática atual, que exige deles novas formas de trabalho nas escolas, depois de analisarmos os cursos de formação docente, em suas propostas curriculares, fomos às escolas para entender melhor como estão estas práticas em sua relação com os momentos de formação vivenciados pelos docentes.

O lócus desta fase da pesquisa são oito escolas da rede municipal de ensino em Santos.

A Secretaria de Educação de Santos - SEDUC - organiza as escolas em diferentes zonas, de acordo com os bairros da cidade e sua proximidade geográfica. Assim, a cidade de Santos conta com quatro zonas escolares: a zona leste, a zona noroeste, os morros e a área continental. Tanto a zona noroeste quanto os morros são consideradas áreas mais periféricas, com uma população de menor renda econômica, e com menos acesso a bens de consumo. A zona leste abriga os bairros considerados de classe média, ainda que, por ser uma zona abrangente, apresente uma oscilação entre os diversos bairros que a compõe, contando assim com bairros onde a maioria da população é de classe média, mas também com bairros que tem uma população com menor poder aquisitivo ${ }^{14}$.

Para a realização da pesquisa, após diálogo com dirigentes da Secretaria de Educação, optou-se pela zona leste, em função de conter uma população com maiores possibilidades econômicas, o que nos faz supor que tenham maior acesso a bens de consumo, tais como a utilização de canais pagos de TV, acesso a rede mundial de computadores, ao uso de celulares, o que constitui um cenário mais propício para a realização desta pesquisa.

Trabalhamos com oito escolas localizadas na Zona Leste: as escolas são chamadas na Secretaria Municipal de Educação de Unidade Municipal de Ensino UME. Fizemos a pesquisa em oito unidades municipais de ensino, que serão

\footnotetext{
${ }^{14}$ Segundo dados da Secretaria de Assistência Social (2005)
} 
apresentadas neste trabalho, por questões éticas, de preservação da identidade dos participantes da pesquisa, pelas letras A, C, D, L, M, ME, P e O. As escolas estão localizadas em diferentes bairros, que são: Macuco; Encruzilhada; Aparecida; Vila Belmiro; Gonzaga; Ponta da Praia e Marapé.

Nestas oito escolas realizamos a pesquisa com 113 professores do ensino fundamental I, ou seja, professores que trabalham com crianças do $1^{\circ}$. ao $5^{\circ}$. anos. Escolhemos trabalhar com o Ensino Fundamental I em função da faixa etária dos alunos, que já permite a opção deles diante das programações que assistem na TV, bem como dos sites em que navegam, bem como já estabelecem diálogos com outras pessoas a respeito de seus cotidianos. Além disso, trabalhamos nesta pesquisa na perspectiva de cursos de formação inicial de professores, os cursos de Pedagogia, que preparam docentes para a educação infantil e para os anos iniciais do Ensino Fundamental.

Fomos às escolas no horário das reuniões de professores, que na Secretaria de Educação de Santos são chamadas de HTPs - Hora de Trabalho Pedagógico e acontecem duas vezes por semana, com todo o grupo de professores reunidos, coordenados por um componente das equipes técnicas das escolas, preferencialmente pelo orientador ou coordenador pedagógico ${ }^{15}$. As reuniões acontecem às terças e quintas feiras, das $11 \mathrm{~h} 45 \mathrm{~min}$ às $12 \mathrm{~h} 45 \mathrm{~min}$ para os professores do turno da manhã e das $17 \mathrm{~h} 45 \mathrm{~min}$ às $18 \mathrm{~h} 45 \mathrm{~min}$ para os professores do turno da tarde. Entre os meses de setembro e dezembro de 2010, fomos às oito escolas, nos horários de reuniões, previamente agendados com as equipes técnicas das escolas. Como as escolas têm classes de ensino fundamental I nos dois períodos - manhã e tarde - fomos, no mínimo, duas vezes em cada escola.

Nestes encontros com os professores, explicamos sobre o que tratava a pesquisa e seus objetivos. Em seguida, entregamos o questionário para cada um deles. Foram momentos muito significativos para a realização da pesquisa. Como os professores estavam todos juntos nas salas de reunião, respondiam o questionário conversando uns com os outros, trocando ideias, tirando dúvidas. Também dialogavam comigo, pesquisadora, fazendo inferências a partir do que estava no questionário, opinando, se posicionando. Estes momentos me permitiram ter uma ideia mais clara da forma com que os professores vêem seu trabalho, como interagem uns com os outros, como são

\footnotetext{
${ }^{15}$ A rede municipal de ensino de Santos conta, em suas equipes técnicas com: diretor de unidade, assistente de direção; coordenador pedagógico e orientador educacional. Também há a figura do supervisor de ensino que trabalha com blocos de duas ou três escolas.
} 
algumas práticas de comunicação vivenciadas nas escolas entre os docentes e entre estes e as equipes técnicas das escolas.

Apresento em seguida, a análise dos dados dos questionários aplicados aos 113 professores das oito escolas da rede municipal de Santos. Os dados serão analisados tendo como referência inicial a preocupação maior desta pesquisa: a formação de professores em sua relação com a sociedade midiática atual, onde os alunos aprendem de formas diferenciadas, exigindo dos professores habilidades comunicativas com múltiplas linguagens, em suportes diferenciados, numa nova configuração social, atravessada por tecnologias comunicacionais.

\subsection{O que dizem os dados coletados:}

Na primeira fase da pesquisa, trabalhamos na análise das propostas curriculares dos seis cursos de Pedagogia da cidade de Santos, para entender como se dá o processo de formação docente no que tange à sua articulação com as exigências das sociedades midiáticas atuais, perpassadas pela convivência cotidiana com diferentes mídias, nos constituindo como sujeitos de uma forma diferenciada, inclusive nas formas como aprendemos e ensinamos. Constatamos que os cursos de formação de professores não apresentam um trabalho voltado para questões educomunicacionais, não preparando os futuros docentes para o trabalho com novas linguagens, em suportes diferenciados, que exigem a construção de novas habilidades comunicacionais. Em geral, os cursos de Pedagogia preparam os alunos - futuros professores - para o trabalho com formas de linguagem tradicionais:

É de lembrar que os cursos de magistério e as diversas licenciaturas estavam e estão orientadas, basicamente, para as operações com as linguagens verbal ou numérica: alfabetização, história, geografia, matemática, física. Posto de outro modo, as disciplinas e áreas de formação dos professores tem como referência algarismos, palavras e, inevitavelmente, estão formatadas em textos. Ocorre que falamos, agora, igualmente em outras dimensões discursivas, muitas delas ancoradas nos códigos imagéticos, portanto em distintos mecanismos de produção dos sentidos, e se constituindo a partir dos sistemas complexos: entendidos como produtos da junção das várias modalidades de signos. (CITELLI, 2004: 207) 
Professores formados em cursos que privilegiam a utilização de linguagens tradicionais, como as linguagens verbais e numéricas, sairão dos cursos com esses conhecimentos e habilidades. Logicamente, terão maior dificuldade em lidar no cotidiano de seu trabalho docente com meninos que aprendem utilizando outras formas de linguagem, outros códigos, mais ancorados em imagens, que se apresentam das mais variadas formas, em suportes tecnológicos cada vez mais elaborados e convergentes entre si. Zanchetta afirma que "os professores não passaram pelo exercício de escolarização do conhecimento midiático" (ZANCHETTA, 2008: 11). Ou seja, precisam trabalhar com códigos e linguagens para os quais não foram preparados, sem estudos específicos voltados para o conhecimento midiático. Como nos aponta Sacristán (1995), a prática dos professores será influenciada pela formação que vivenciou, pelo ambiente em vive, com as concepções de mundo que o circundam bem como pelo repertório cultural com o qual tem contato. Ao considerarmos o ensino enquanto prática social entendemos que "essa prática para ser compreendida e transformada precisa ser dialogada e tecida nos significados que emergem dos práticos, daqueles que a concretizam." (FRANCO, 2010:90). Portanto, para pensarmos sobre as práticas docentes em sociedades midiáticas, precisamos entendê-la num contexto mais amplo, envolvendo os processos de formação vivenciados pelos professores, a situação concreta em que estão as escolas onde estes mesmos professores exercem suas práticas cotidianas, as propostas oficiais das políticas públicas educacionais. A prática educativa é extremamente complexa e multirreferenciada.

Pensando nestas questões e reflexões e tendo-as como referencial inicial de análise, elaboramos os questionários para os professores, com a intenção de melhor entender como eles mesmos vêem seu trabalho na relação com as mídias, como percebem sua própria prática docente. A primeira parte é constituída de 8 questões fechadas que visam contextualizar os processos formativos e caracterizar os professores pesquisados. Elas abordam: faixa etária, gênero, local do curso e tempo de formação. Elas também abordam as disciplinas estudadas durante a formação, para que possamos compreender quais aprofundamentos teóricos o futuro docente teve acesso no seu período de formação inicial. Questionam ainda o ano para o qual o professor leciona e quais recursos ou materiais costuma utilizar em suas aulas, para poder dimensionar como ele percebe sua própria prática docente cotidiana. 
Na segunda parte, propusemos cinco questões abertas, que abordam o porquê da utilização de determinados materiais nas aulas; o uso de TV e computador e como o professor se sente preparado - ou não - para o trabalho com essas mídias.

Inicio agora a apresentação e análise das questões fechadas.

\subsubsection{Contextualizando quem são os docentes da pesquisa:}

Quanto à faixa etária, os professores tinham quatro opções como resposta: se tem entre 20 e 25 anos; entre 26 e 30; entre 31 e 40 ou mais de 40 anos. Esta questão tinha por objetivo primeiro conhecer em qual faixa etária estão os professores em atuação na rede municipal, visto que desenvolvemos como uma das ideias deste trabalho a de migrantes digitais - nascidos numa era menos tecnológica, com processos de comunicação menos complexos e um cotidiano não atravessado por mídias eletrônicas e digitais - e nativos digitais - nascidos na era dos avanços tecnológicos e com um cotidiano perpassado pela convivência com múltiplas mídias, nas mais diferentes linguagens (PRENSKY, 2006).

De um total de 113 professores, 74 tem mais de 40 anos de idade. Somente três professores têm entre 20 e 25 anos.

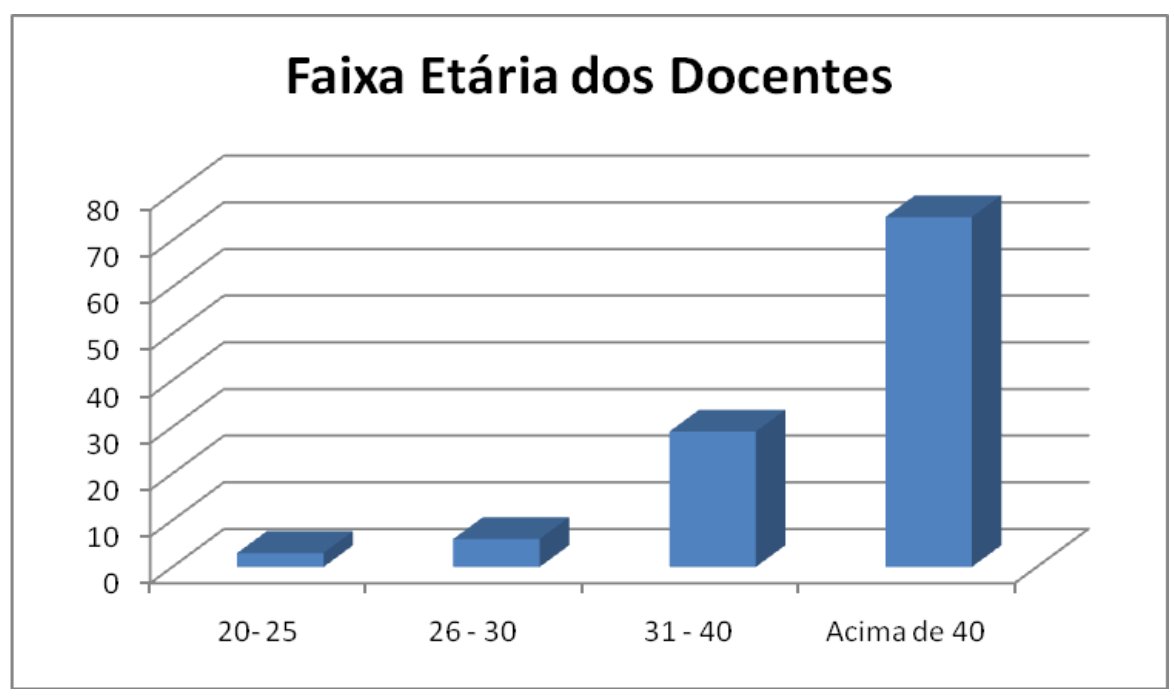

Gráfico 01. Faixa etária dos docentes

A maioria dos professores, por inferência, nasceu nas décadas de 1950 e 60, foram crianças em uma sociedade que ainda usava pouco a TV ou nem tinha acesso à mesma. 
Cresceram sem celular e sem internet. Se tomarmos a história da educação no Brasil como referência, provavelmente, foram alunos de escolas tradicionais, onde os processos de ensino e aprendizagem eram pautados em códigos verbais, com transmissão de conteúdo pelos professores, numa construção de pensamento mais linear. Nas palavras de Citelli: "marcados por uma cultura analógica, cujo aparelho perceptual e cognitivo trabalha, ainda, à base dos mecanismos lineares" (CITELLI, 2010: 20)

Essa geração de professores, de migrantes digitais, está nas escolas lidando com a geração de nativos digitais. Duas gerações convivendo com formas diferentes de processar pensamentos e informações e uma delas sendo a responsável por mediar a construção de conhecimentos da outra. Como fazer para que professores que, na sua constituição como sujeitos, não tiveram o cotidiano impactado por mídias digitais e informatizadas, possam aprender a trabalhar com uma geração nascida no meio de inúmeras transformações tecnológicas, cada vez mais rápidas, operando com muitas informações, chegadas das mais variadas fontes? Esse é um dos questionamentos que faço, para os quais busco alternativas nos processos de formação inicial dos docentes. Professores que não foram preparados em sua formação inicial para um trabalho com mídias, com certeza terão maior dificuldade para construir capacidades comunicativas para esse trabalho. Bem como também não terem experimentado práticas comunicativas midiáticas em seu processo de formação é algo a ser considerado. Desenvolvemos uma profissionalidade docente também por meio de nossas experiências formativas. Se essas experiências privilegiavam alguns códigos e padrões, esses mesmos códigos estarão presentes na constituição da futura profissionalidade. Portanto, não se trata nesta pesquisa de culpabilizar o professor pelas práticas pedagógicas que exerce, mas compreendê-las para poder pensar novos modelos de formação inicial que respondam às demandas das sociedades midiáticas atuais, bem como também apontar possibilidades para a formação contínua desses professores.

$\mathrm{Na}$ segunda questão apresentada aos professores, perguntamos sobre gênero. Entre 113 professores, 107 são mulheres e somente 6 são homens, o que evidencia a já bastante identificada e discutida feminização do magistério. 


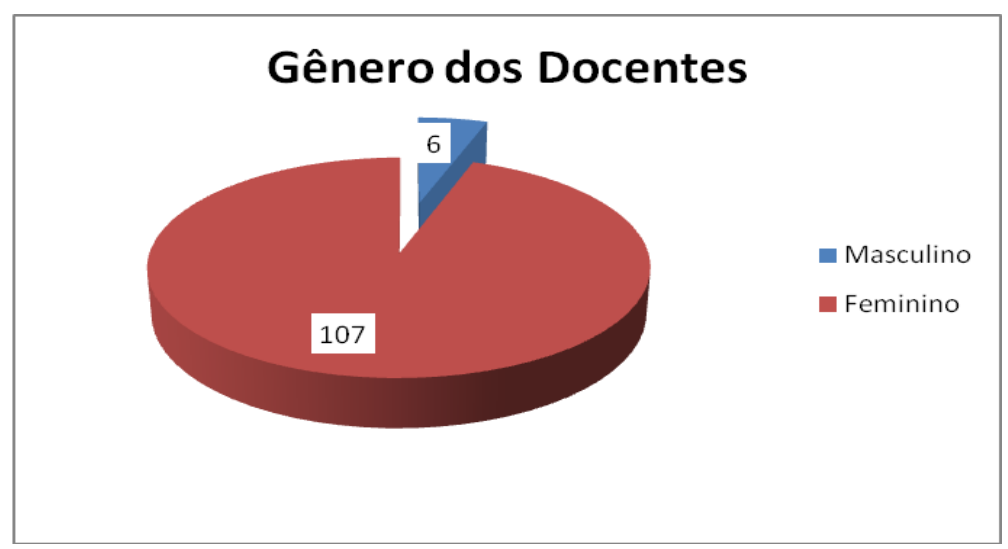

Gráfico 02. Gênero dos docentes

Em relação às mulheres, se formos considerar o histórico dos processos educacionais e a construção das representações sociais, veremos que são consideradas mais avessas ao uso das tecnologias, uma vez que foram ensinadas e preparadas, de forma geral, para as funções mais domésticas, de cuidar dos filhos e do marido, de cuidar das coisas da casa, da família. Mesmo sendo professoras, levaram essa concepção do cuidar para as escolas ${ }^{16}$. Imaginemos uma geração de migrantes digitais, sem hábito de uso diário de tecnologias e somemos a isso o fato da maioria ser composta de mulheres! Temos como número maior de professores em atuação nas escolas, um grupo que, ao longo de sua história de vida, inclusive de construção da identidade profissional, não desenvolveu hábitos e costumes com o uso de mídias eletrônicas e digitais.

A terceira questão apresentada às professoras e professores, perguntava sobre o local de formação universitária, apresentando as seis instituições da cidade de Santos que oferecem o curso de Pedagogia e abrindo a possibilidade de colocar alguma outra instituição. Como podemos ver no gráfico a seguir, a maioria dos professores formou-se na UNISANTOS. Se retomarmos os dados do capítulo anterior e a análise dos quadros curriculares, veremos que justamente a UNISANTOS não apresenta nenhuma disciplina em seu quadro, que faça referência direta a assuntos da comunicação midiática.

\footnotetext{
16 Sobre feminização do magistério, dentre vários autores, podemos citar Vianna 2001/02 e Chamon 2006.
} 


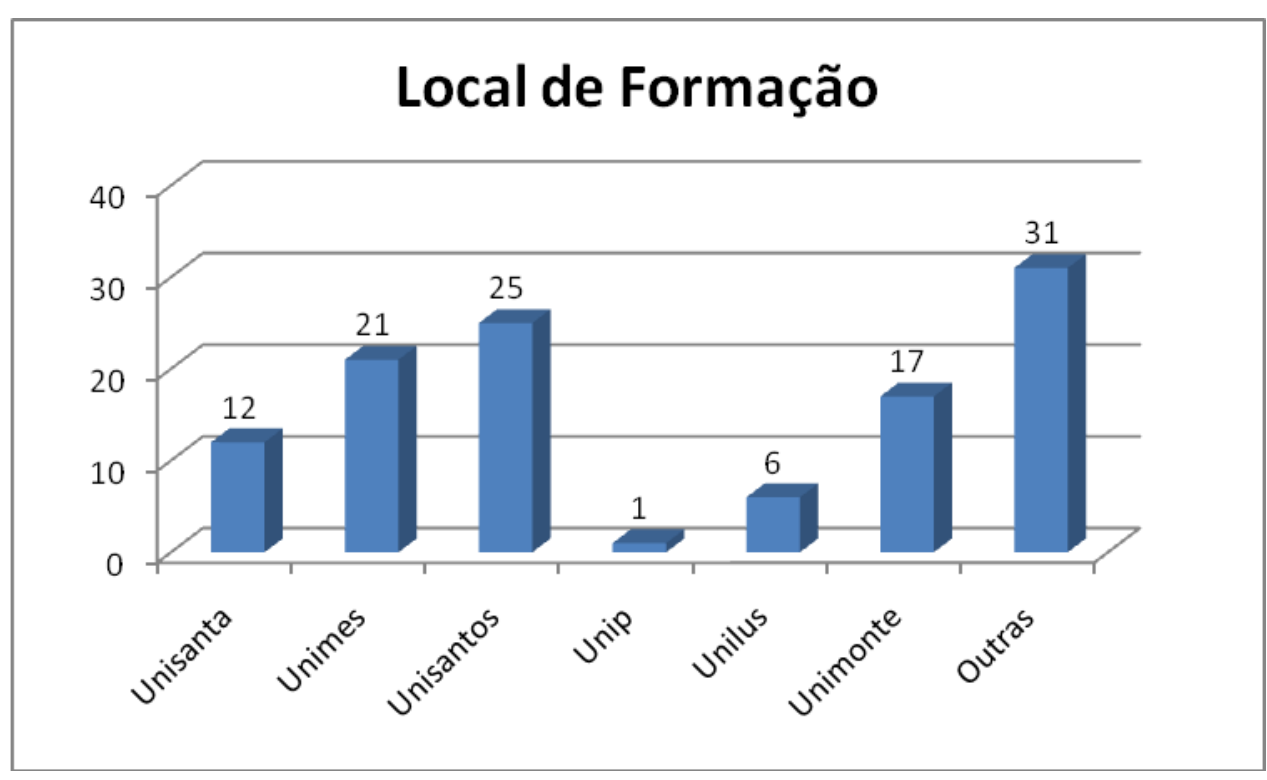

Gráfico 03. Local da formação inicial dos docentes

A quarta questão perguntava em qual curso as professoras e professores se formaram. Do total de 113 sujeitos, 93 formaram-se no curso de Pedagogia, o que nos dá um percentual de 82,3\%. Os cursos de Pedagogia aparecem como lócus principal da formação de docentes, o que acentua a importância de repensarmos como estão ocorrendo os processos de formação nestes cursos, onde os futuros docentes são preparados para seu trabalho nas escolas.

$\mathrm{Na}$ quinta questão, o objetivo era saber há quanto tempo os docentes estão formados, para pensar essa formação inicial dentro de um contexto histórico, tanto dos processos de formação quanto das transformações pelas quais a sociedade vem passando. Os professores podiam responder entre cinco opções: formados há menos de um ano, entre um e três, de três a cinco, de cinco a dez e há mais de dez anos. Das 113 professoras e professores, 73 estão formados há mais de 10 anos. Outros 26 estão formados entre cinco e dez anos. Formados há menos tempo, temos cinco professores entre três e cinco anos e quatro formados entre um e três anos. Somente um professor respondeu que está formado há menos de um ano. Podemos visualizar melhor no gráfico a seguir. 


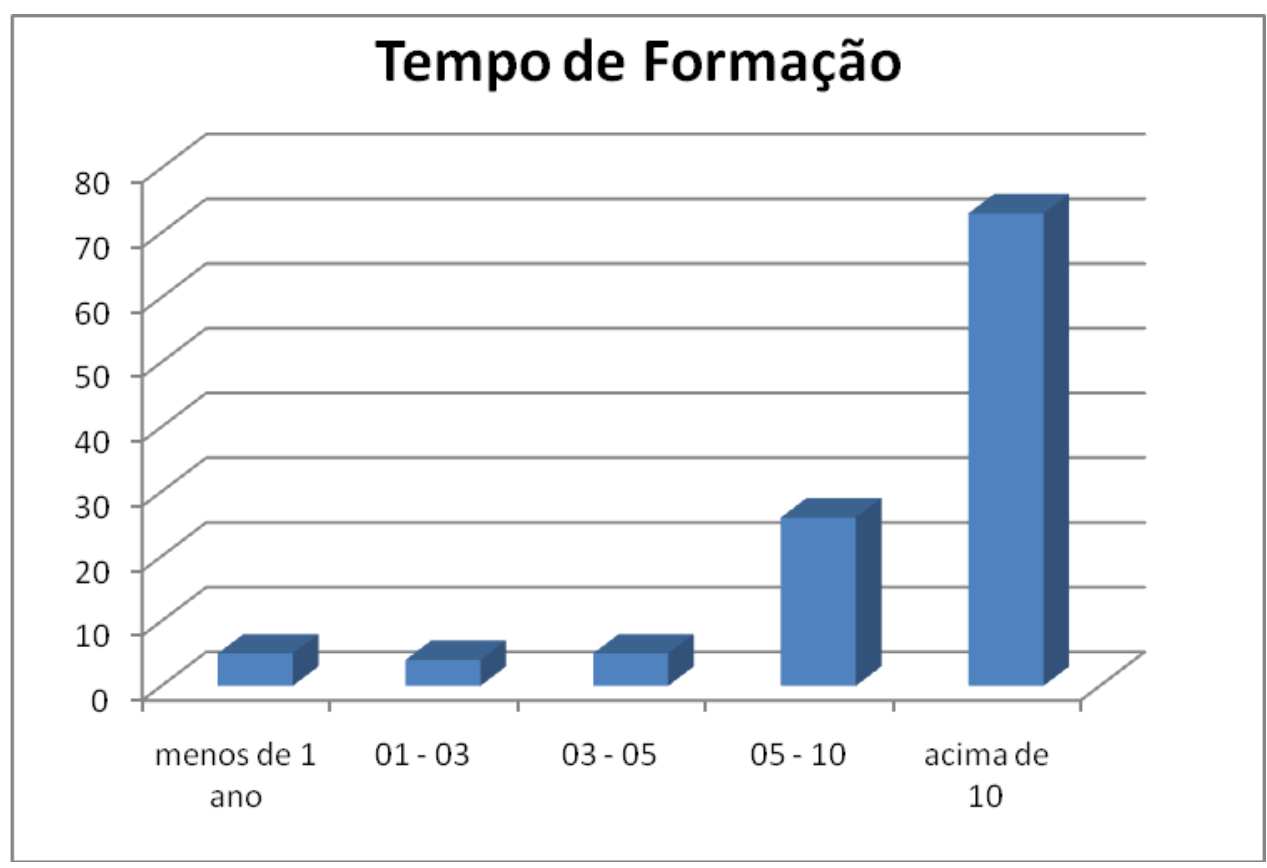

Gráfico 04. Tempo de formação

Considerando de forma percentual, temos $64,6 \%$ das professoras e professores, um pouco mais da metade, formados há mais de 10 anos. Se cruzarmos esta questão com a primeira, que fazia alusão à faixa etária, podemos inferir que temos um grupo de professores formados entre 1980 e 2000, visto que 74 dos sujeitos tem mais de 40 anos. Foram formados numa época de transição da história brasileira, logo após o período da ditadura militar. Esta também foi uma época de muitos debates na área de educação, inclusive na área de formação de professores, que culminou com um período de reformas educacionais e formulação de políticas públicas (GHEDIN, LEITE e ALMEIDA, 2008).

Temos um grupo de professores formados num momento em que os cursos de Pedagogia do país estavam passando por reformulações, tentando construir um caminho mais fundamentado para a formação inicial de professores. Ainda assim, "pesquisas recentes tem mostrado que os professores não estão recebendo preparo inicial suficiente nas instituições formadoras para enfrentar os problemas encontrados no cotidiano de sala de aula." (GHEDIN, LEITE e ALMEIDA, 2008: 23)

Para podermos compreender um pouco mais sobre o processo de formação dos docentes, a sexta questão perguntava sobre as disciplinas cursadas no período inicial de estudos. Colocamos como opções para os professores, as disciplinas usuais dos currículos de Pedagogia, tais como Didática, Metodologia de Ensino, Sociologia e 
História da Educação junto a disciplinas que compõe os quadros curriculares mais recentemente, como Tecnologia e Educação, Informática, Diversidade Cultural e Alfabetização e Letramento.

Quanto às disciplinas mais tradicionais temos o seguinte: dos 113 professores, 104 cursaram Didática em seu período de formação inicial, dando um percentual de 92,03\%, ou seja, quase todos os professores tiveram acesso ao conteúdo de Didática. Os números permanecem iguais ou praticamente iguais para as disciplinas de Metodologia de Ensino - 104 professores - Sociologia - 103 - e História da Educação, com 100 dos 113 professores. Estes números nos trazem a perspectiva já anunciada por GATTI E BARRETTO (2009), quando ao trabalharem com análise de quadros curriculares de formação de professores em todo o país, encontram currículos com disciplinas com maior ênfase no embasamento teórico a partir de diferentes áreas do conhecimento do que disciplinas que estejam ligadas a profissionalização mais específica dos professores, não construindo efetivamente uma articulação teórico-prática como proposto nos documentos oficiais sobre formação de professores.

Os números das disciplinas afeitas a discutir aspectos da comunicação midiática e dos avanços tecnológicos impactando a educação são bastante diferentes: dos 113 professores, somente 39 cursaram a disciplina de Tecnologia e Educação, num percentual de $34,51 \%$. Os números são praticamente iguais para a disciplina de Informática: 35 professores estudaram Informática. As respostas dos professores caminham no sentido da confirmação de nossa hipótese, de que os cursos de formação inicial possivelmente não estão preparando os futuros docentes para as novas demandas de trabalho que estão se apresentando em função das transformações sociais. Mesmo as disciplinas não ligadas diretamente às questões comunicacionais, mas que trabalham com conceitos necessários à nossa sociedade complexa atual, como a disciplina Diversidade Cultural, apresenta números que nos fazem pensar: dos 113 professores, somente 34 cursaram a disciplina. 


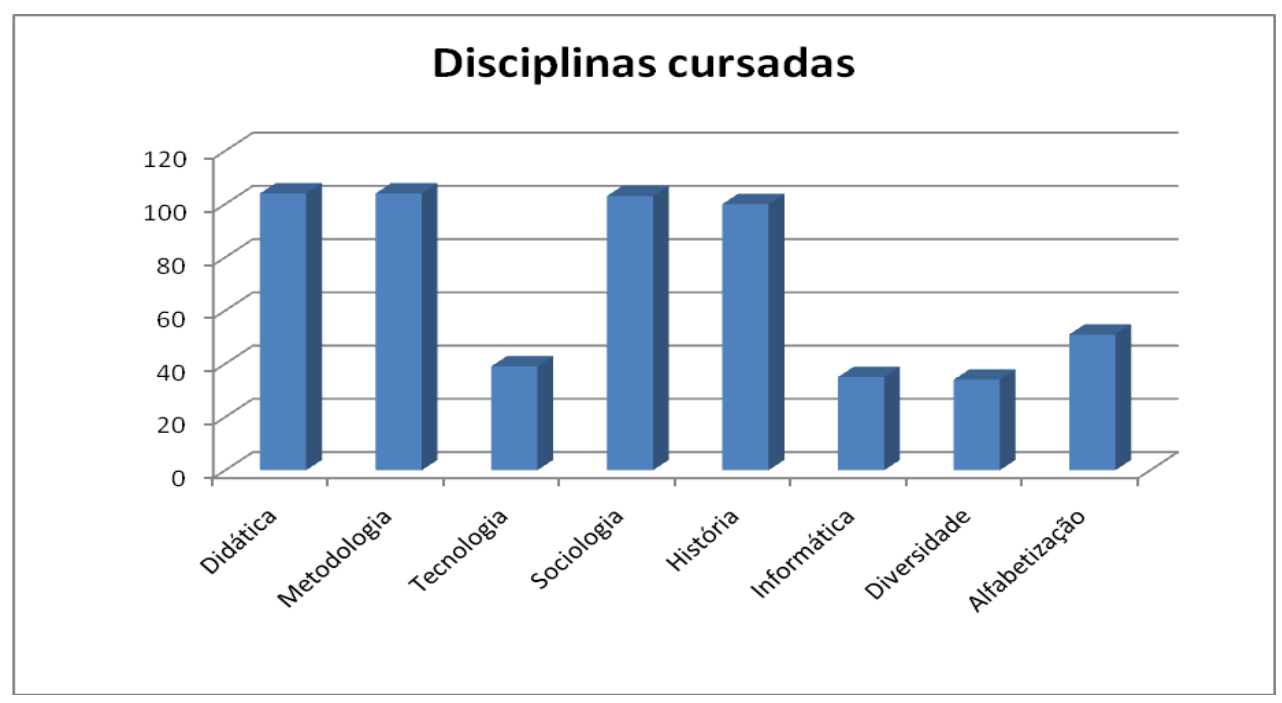

Gráfico 05. Disciplinas cursadas

A análise das disciplinas cursadas na formação inicial pelos professores em atuação nas escolas públicas municipais também tem que ser considerada em articulação com o que dizem os documentos oficiais sobre os objetivos do Ensino Fundamental. Os Parâmetros Curriculares Nacionais (BRASIL, 1997) abordam claramente a necessidade do trabalho com novas tecnologias e estimulam o uso de novas linguagens. O perfil de formação de nossos docentes nos cursos de Pedagogia parece não estar compatível com o perfil de um docente que possa implementar as políticas públicas expressas nos documentos referentes à Educação Básica. Ao termos cursos de formação que enfatizam mais conteúdos teóricos do que conteúdos ligados à prática docente e ao desenvolvimento profissional do professor, diante do quadro de mudanças da sociedade atual, entregamos à sociedade professores que não foram formados para as situações nas quais trabalharão. Quando iniciam seu trabalho nas escolas ficam perplexos diante de tantas e tão rápidas mudanças, para as quais não foram minimamente preparados em sua trajetória de formação e para as quais tem que dar respostas concretas em seu trabalho cotidiano.

Ao analisarmos os dados dos questionários sobre o tempo de formação dos docentes, cruzando-os com os dados sobre as disciplinas cursadas durante a formação inicial, percebemos que os professores formados há mais tempo só tiveram as disciplinas mais tradicionais, como Didática, Sociologia e História da Educação. Como o maior número dos professores em atuação nas escolas está formado há mais de dez 
anos, evidencia-se a possibilidade de pensarmos que a maior parte dos professores não foi preparada, durante a formação inicial, para as demandas sociais e culturais atuais.

O cotidiano de nossas escolas e dos alunos que estão nelas todos os dias é perpassado pelas questões comunicacionais, pelas questões midiáticas. Somos interpelados todos os dias por inúmeras imagens e sons, que nos constituem como pessoas e conversamos pouco sobre isso, bem como também vivenciamos pouco essas questões em nossos cursos de formação docente. Enquanto professores, precisamos estar preparados para essa interlocução com questões comunicacionais midiáticas, para dialogar com as novas gerações de alunos. Nas palavras de Fisher:

\begin{abstract}
...a escola ainda não está suficientemente instrumentalizada para dirigir-se à criança telespectadora, para comunicar-se com o adolescente nascido, criado e 'alfabetizado' pela TV (sem falar nas outras tecnologias, como o computador, e as respectivas formas de comunicação viabilizadas a partir delas). Como diria a estudiosa Elizabeth Ellsworth - referindo-se aos modos de nós, educadores e educadoras, falarmos às crianças e aos adolescentes, aos modos de endereçarmos nossas aulas e nossos currículos - talvez não tenhamos ainda conseguido uma sintonia com esses novos alunos. (...) Há, portanto, um longo caminho a ser percorrido, no sentido de um trabalho amplo e diversificado sobre as múltiplas relações entre mídia, cultura e sociedade, no espaço escolar. (FISHER, 2006: 31-32)
\end{abstract}

Em nossos currículos de formação de professores precisamos percorrer esse caminho de articulação entre mídia, cultura e sociedade, formando professores que dialoguem com os desafios trazidos pelos ecossistemas comunicativos, articulando-os às dimensões pedagógicas e didáticas.

$\mathrm{Na}$ sétima questão perguntamos aos professores para quais anos lecionavam. Conforme pode ser visto no gráfico apresentado em seguida, temos a seguinte composição: 19 lecionam para o primeiro ano, 18 para o segundo, 21 para o terceiro, 28 para o quarto e 14 para o quinto ano. Dez professores responderam que lecionam para todos os anos - lembrando que temos os professores de artes, professores de informática educativa - POIES - e professores de educação física, que trabalham no ensino fundamental I, nos diversos anos. 


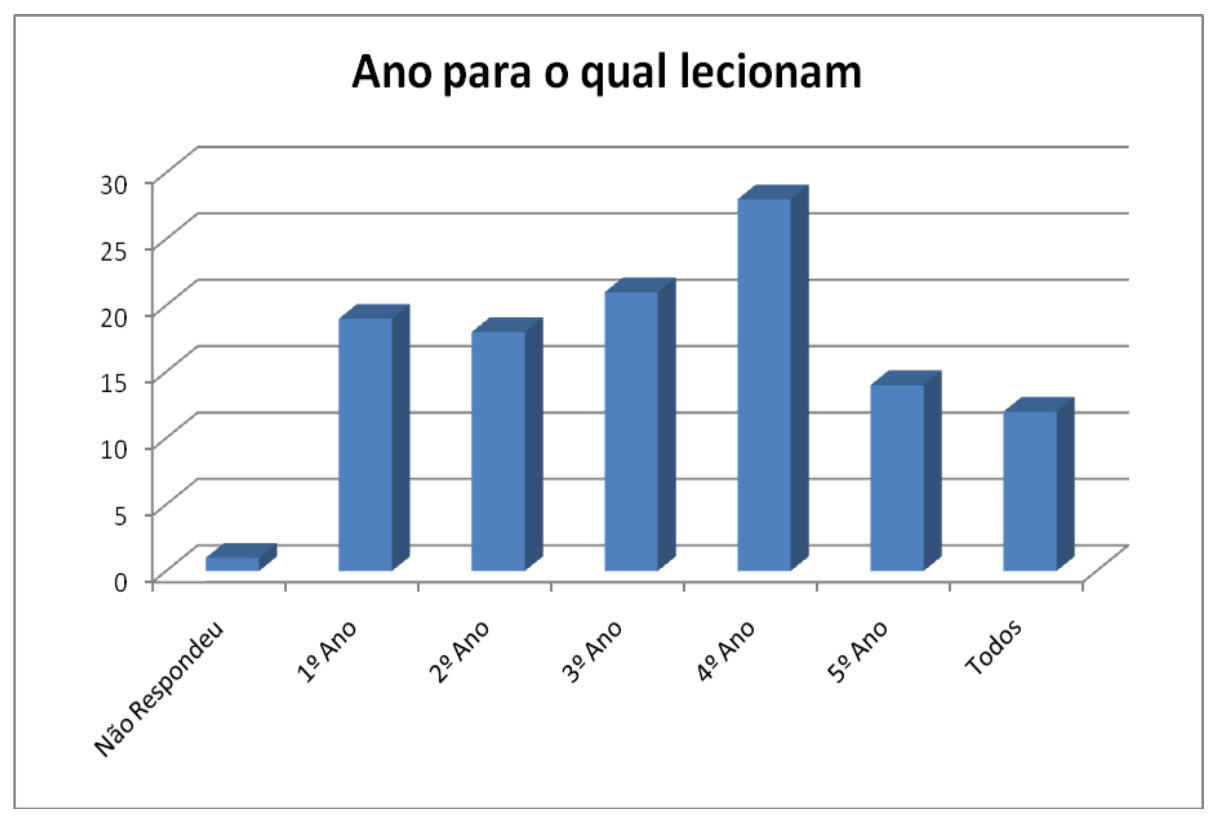

Gráfico 06. Ano para o qual lecionam

Quanto aos POIEs, cabe explicar que são os professores de informática educativa, que trabalham nos laboratórios de informática nas escolas da rede municipal. São acompanhados pedagogicamente pelo Núcleo Tecnológico Municipal, assessorados por professoras da rede que visitam as unidades municipais e buscam uma articulação entre a informática e os demais componentes curriculares da escola. A opção por ter em seu quadro professores de informática faz parte das preocupações da Secretaria Municipal de Educação, que tem como um dos seus eixos da organização didático-pedagógica a inclusão digital.

Há que se considerar que existem dificuldades na operacionalização do trabalho dos POIEs, tanto por problemas estruturais nas unidades escolares, como pelo trabalho que ainda está em construção para que o coletivo da escola, inclusive as equipes técnicas, percebam a importância do trabalho com novas mídias e estas passem, explicitamente, a compor os projetos pedagógicos das unidades. Ainda assim, destacase que é um trabalho diferenciado entre as cidades da região da Baixada Santista e mostra um caminho a ser trilhado, quanto ao trabalho com as novas demandas sociais, articulado ao cotidiano das atividades escolares. A existência dos POIEs, enquanto política pública, também evidencia a necessidade de um diálogo mais estreito entre as instâncias formadoras - universidades e faculdades - e os órgãos gestores de políticas públicas. Enquanto analisamos nos currículos dos cursos de Pedagogia, por meio das ementas propostas, que não é um foco dos processos de formação inicial a preocupação 
com as novas mídias e as novas habilidades que exigem dos professores, há um olhar da Secretaria de Educação para essa questão, que poderia estar mais articulada num trabalho conjunto entre os gestores das políticas públicas e os cursos de formação inicial docente das instituições formadoras.

$\mathrm{Na}$ oitava questão perguntamos aos professores quais recursos ou materiais costumam usar nas aulas, apresentando um quadro com o nome dos recursos mais usuais - gibis/histórias em quadrinhos; músicas; lousa; programas de TV: telenovelas, desenhos, comerciais; computador: softwares, internet; revistas e/ou jornais; livros paradidáticos; DVDs/filmes; outros/quais? - e seis opções de periodicidade - nunca; toda aula; duas a três vezes por semana; uma vez por semana; uma vez por mês; outra periodicidade/qual.

Vejamos os números e as colocações dos professores - pois alguns completaram explicitamente o quadro escrevendo - para essa questão. Primeiro, vamos apresentar cada recurso e como, em termos de periodicidade, os professores dizem usá-los. Depois, destacaremos algumas colocações dos professores.

Quanto à utilização de gibis e histórias em quadrinhos nas aulas, aproximadamente metade dos 113 professores afirma usá-los como recursos ao menos uma vez por semana. Nove professores dizem usar toda aula.

Na opção música, 57 professores estão nas opções uma vez por semana, duas a três vezes por semana ou toda aula, permanecendo próximos da opção gibi/ HQ, ou seja, aproximadamente metade dos professores utiliza música como recurso nas aulas costumeiramente.

Quanto à utilização da lousa, os dados mostram que 88 professores dizem usá-la todas as aulas, num percentual de $77,87 \%$. 


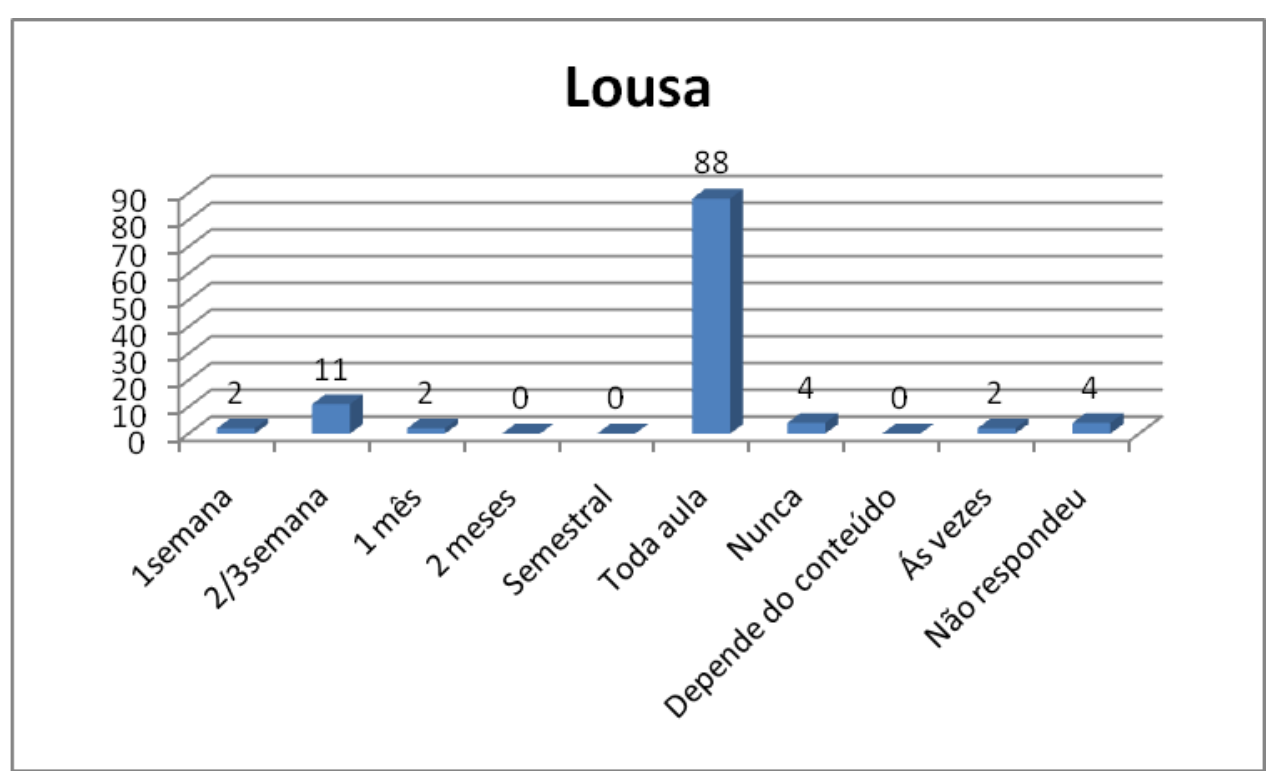

Gráfico 07. Utilização da lousa nas aulas

Esse é um dado que evidencia alguns aspectos das nossas análises neste trajeto de pesquisa. Numa sociedade contemporânea e midiática como a nossa, onde os alunos trazem novos anseios quanto à aprendizagem e situam-se no mundo por meio de inúmeros artefatos tecnológicos, o material fartamente utilizado por professores em suas aulas é a lousa, que nos remete a uma representação social e a um cotidiano escolar de um local de transmissão de conteúdos. Uma lousa na frente da classe onde o professor escreve e os alunos copiam, sentados cada um no seu devido lugar. Ainda que possamos pensar que a lousa pode ser usada em conjunto com outros materiais, sua utilização diária e constante nos remete a uma idéia bem tradicional de aula e de escola.

Vejamos o que os professores apontam quanto à utilização de programas de TV em suas aulas. Um único professor diz que utiliza programas de TV em todas as suas aulas, o que nos dá um percentual de $0,88 \%$. Enquanto a lousa era utilizada por quase $80 \%$ dos professores todas as aulas, a TV fica abaixo de $1 \%$ ! Os números falam por si! Dos 113 professores, 21 afirmam nunca usar a TV em suas aulas, configurando 18,58\% do total, o que também é um número representativo, nos indicando a ausência de trabalho com essa mídia nas aulas. Temos um número de 22 professores que afirmam usar a TV e sua programação pelo menos uma vez na semana, o que também nos traz números interessantes. Aproximadamente 19\% dos professores afirmam usar a TV com certa frequência, o que pode indicar que começamos a ter algumas mudanças no fazer docente nas aulas. 


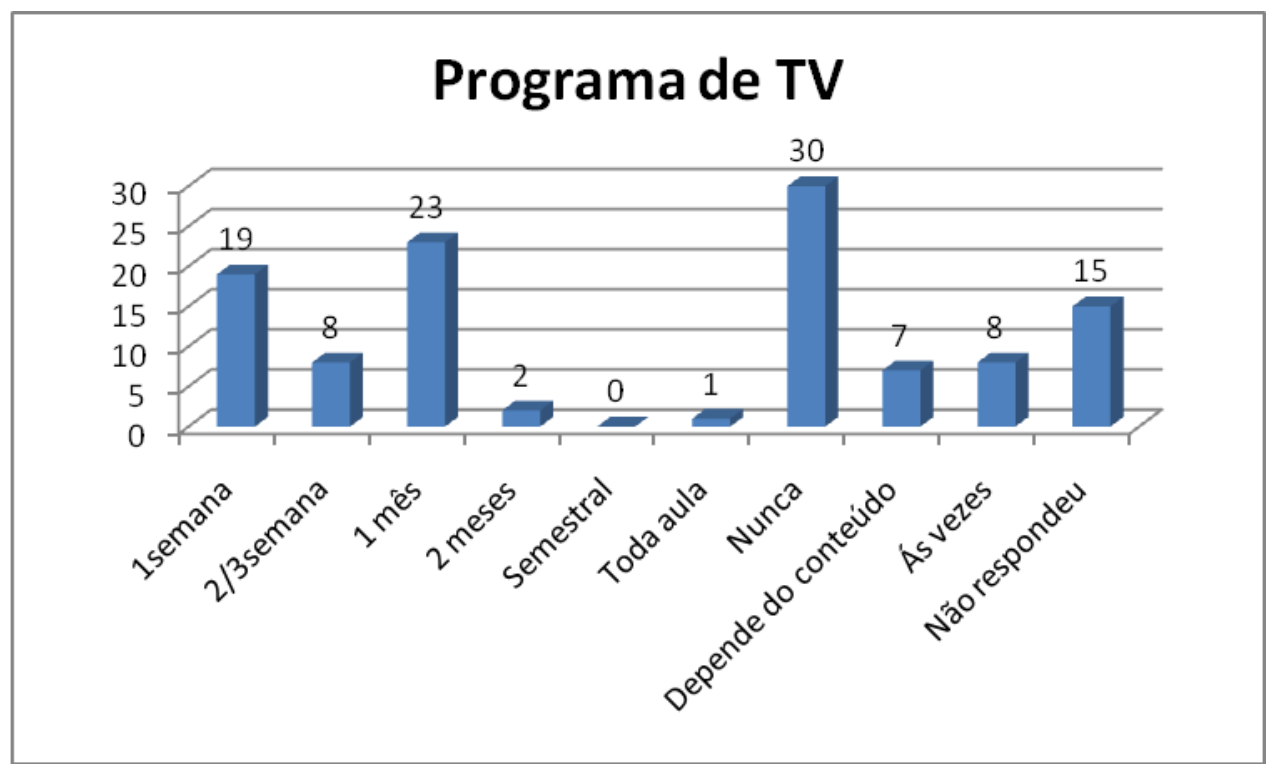

Gráfico 08. Utilização de programas de TV nas aulas

Destacamos que essa mudança no fazer docente cotidiano passa necessariamente pelos processos de formação. O uso de recursos, equipamentos e linguagens precisa ser aprendido, analisado, discutido. Um espaço para que isso aconteça é o espaço dos cursos de formação inicial, sem desconsiderar a importância das escolas como local de formação continuada, com encontros e reuniões de professores, onde possam ser construídas alternativas para o trabalho cotidiano com os alunos. Neste sentido, destacamos a preocupação de Franco: "preocupa-me muito o caminho que nossos cursos de formação vêm tomando e, mais que isso, as condições precárias, aviltantes, alienantes das demais escolas e demais instituições educativas. (FRANCO, 2010: 93)

Quanto à utilização do computador, softwares ou internet, em suas aulas, os professores responderam o seguinte: 67 usam uma vez por semana, aproximadamente $60 \%$. Este número provavelmente está relacionado à política pública da Secretaria de Educação de Santos, que tem POIEs - professores de informática educativa - em seus quadros. Esses professores são selecionados e trabalham em blocos de duas ou três escolas, indo uma vez por semana em cada uma delas. Os professores titulares das salas podem acompanhar ou não os professores de informática aos laboratórios. Em geral, os professores da sala não acompanham os POIEs, que vão com as turmas de alunos para a “sua' sala de aula, o laboratório especifico. Ainda assim, com a existência dos professores específicos para o trabalho com informática, 15 professores afirmam não 
usar nunca o computador em suas aulas. A figura do professor de informática fica um pouco descolada na escola, não colaborando para a construção de uma nova profissionalidade docente que envolva todos os professores. Logicamente, a existência de uma política de trabalho instalada pela Secretaria, enquanto órgão gestor, no cotidiano das escolas, traz alguns resultados, sem dúvida. Os números apresentados pelos professores em suas respostas evidenciam que começa a existir uma prática pedagógica mais articulada à cultura digital. Entretanto, para que seus efeitos sejam efetivos, ela deve ser uma prática do coletivo da escola e não de um professor específico. A elaboração e implantação de políticas públicas educacionais é uma forma de construir novos caminhos no cotidiano das escolas, no cotidiano de alunos e professores. Também sem dúvida, as políticas colocadas em execução pelos órgãos gestores devem dialogar com os cursos de formação inicial de docentes, levando-os a repensarem seus quadros curriculares em função das demandas exigidas pelas escolas e pelo trabalho cotidiano dos professores. Esta articulação entre órgãos gestores e universidades e faculdades é cada vez mais necessária, para que, na construção de diálogos, haja um trabalho mais focado nas situações reais vivenciadas nas escolas, com a colaboração dos estudos e conhecimentos de todas as redes de saberes e fazeres, das universidades, dos colegiados das escolas, das comunidades que estão no entorno das instituições.

Quanto à existência de POIEs - professores de informática educativa - pode ser encarada como uma situação provisória. De certa forma, é interessante que existam professores com uma função específica de trabalhar com os computadores e suas linguagens, com a rede mundial e todas as possibilidades comunicativas e educacionais que isso traz. Por outro lado, a utilização das novas mídias e linguagens, deve ser de todos os professores da escola e não somente de alguns, selecionados especificamente para isso. O trabalho deve caminhar no sentido da escola, enquanto um coletivo, assumir que pode utilizar todas as formas possíveis de linguagens, vivenciadas e utilizadas pela sociedade, com o envolvimento de todos os professores, alunos, equipe técnica, na construção e desenvolvimento de uma proposta educacional que responda às necessidades da sociedade atual.

Ainda na questão oito, como possibilidade de uso de recursos ou materiais nas aulas, os professores tinham a opção de escolher revistas e/ou jornais. Dos 113 professores, 26 responderam que usam jornais ou revistas, duas a três vezes por semana 
e 32 responderam que usam uma vez por semana, o que nos dá um percentual de 51, $32 \%$ usando com certa frequência. O uso de livros paradidáticos aparece sendo usado toda aula por 33 professores, com $29,25 \%$ do total. Sendo utilizado com frequência semanal, aparece com 48,67\% em relação ao total. São números bem altos, num país como o Brasil, onde ainda temos um número de leitores reduzido, inclusive entre professores. Estes números nos fazem refletir sobre um possível "jogo de imagens", onde os sujeitos da pesquisa apresentam respostas que acreditam que são esperadas pela pesquisadora.

Fazendo referência à utilização de DVDs e filmes, os números apresentam diferença quanto aos outros recursos. Em geral, os professores apontavam certa constância no uso de revistas, jornais, livros paradidáticos. Quando apontam o uso de filmes, 41 deles afirmam usar uma vez por mês, uma frequência bem menor do que os outros recursos, que apareciam sendo utilizados uma, duas ou três vezes por semana. 12 professores não marcam nada, deixando a opção em branco, o que, possivelmente, também é indicativo de que não há diversidade de uso de materiais no trabalho destes docentes. Não assinalam a coluna "nunca", não se pronunciam a respeito da utilização dos DVDs ou filmes, como se não tivessem uma posição ou não soubessem o que responder. Vejamos o gráfico a seguir:

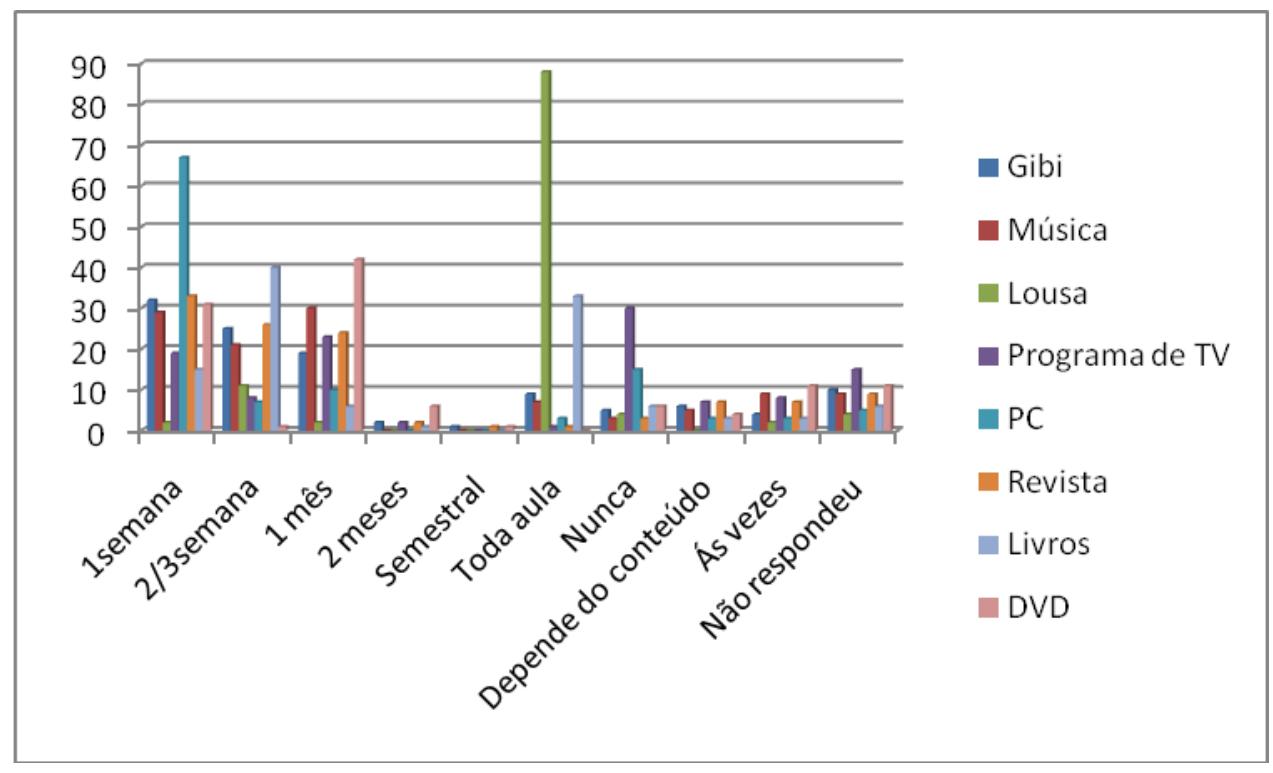

Gráfico 09. Periodicidade do uso de materiais em aula 
Outra opção de escolha dos professores permitia indicar outros materiais, além dos selecionados previamente no quadro. Foram apontados: violão, jogos, dramatização, folders, dicionário e embalagens, da seguinte forma:

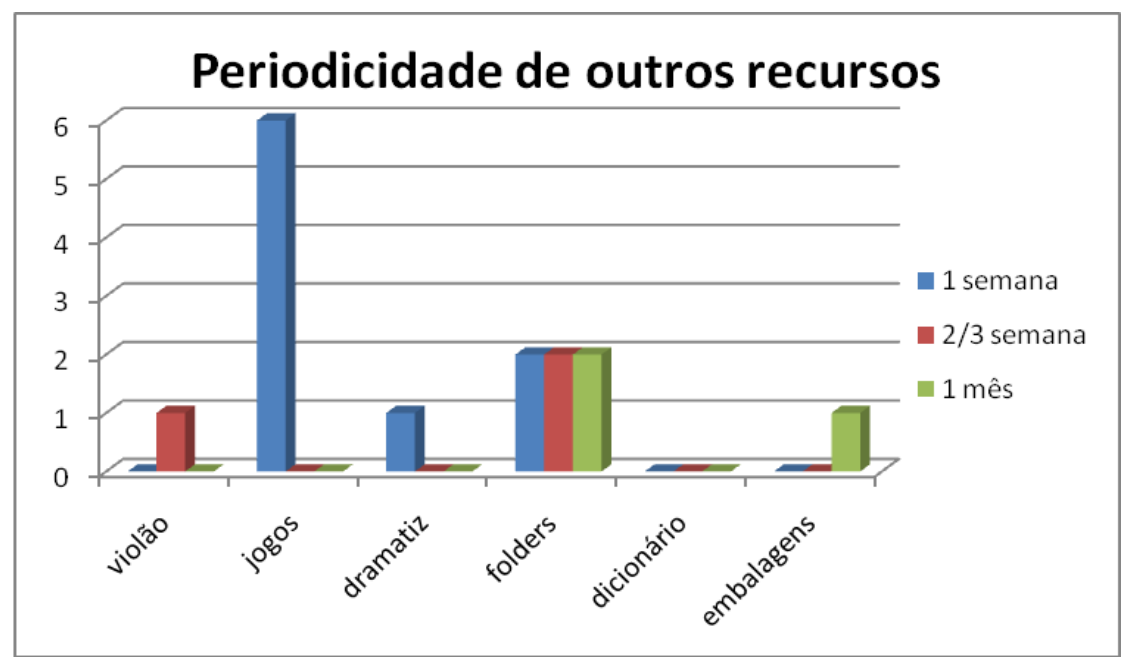

Gráfico 10. Periodicidade de uso de recursos variados nas aulas

O quadro nos mostra uma utilização pouco variada de materiais pelos professores. Dos 113, somente 16 elencaram possibilidades diferentes daquelas dadas no quadro. Diante de tantas alternativas de recursos e linguagens existentes, das inúmeras possibilidades criativas, ainda temos a maior parte dos professores usando a lousa como único recurso em todas as suas aulas.

Esses números nos permitem uma aproximação inicial das respostas dos professores à forma de trabalho desenvolvido nas aulas, segundo a percepção deles mesmos. Em seguida, vamos apresentar algumas respostas escritas, dadas pelos professores, que nos trazem indicadores interessantes ${ }^{17}$. Destacamos que não faremos uma análise da fala dos professores enquanto forma de discurso, mas sim como recurso que nos permite refletir sobre as percepções que eles tem sobre suas práticas pedagógicas. E lembramos ainda que as utilizaremos como referência para discutirmos a formação inicial de professores.

A professora P9 deixa o quadro de materiais completamente em branco e escreve:

"Como sou auxiliar, trabalho com a professora titular." (P9)

\footnotetext{
${ }^{17}$ Os professores serão indicados por letras e números, em codificação feita para preservar a identidade dos mesmos e de suas respectivas escolas.
} 
A professora em questão, que como se vê na posição de auxiliar $^{18}$ e não de professora principal da classe, não aponta o uso de nenhum material de sua escolha nas aulas, o que, praticamente, nos parece indicar a sua ausência da ação docente. O que a professora titular escolher, ela assume também. Essa manifestação é um indicador para se pensar a respeito de como se constroem as relações comunicativas nas escolas, entre os sujeitos envolvidos nos diversos processos educacionais e escolares.

Alguns professores apontam, quanto ao quadro de materiais e recursos, que a escolha da periodicidade tem relação com o conteúdo a ser trabalhado. A professora D3 marca todos os recursos na opção "outra periodicidade" e escreve: "Em nenhum dos casos há uma periodicidade, pois tudo dependerá do conteúdo trabalhado.” (D3)

Entretanto, quanto ao recurso "lousa", ela marca que utiliza "toda aula". A utilização da lousa também não deve depender do conteúdo trabalhado? A resposta demonstra como está incorporado aos hábitos cotidianos de trabalho do professor o uso do chamado 'quadro negro'. Qualquer outro material, para ser utilizado, pensar-se-á primeiro em qual é o conteúdo que o exige. Mas a lousa, não! Estará presente em todas as aulas.

As professoras D10 e D15 também apontam que o uso dos materiais depende do conteúdo. Para falar da periodicidade do uso de gibis, programas de TV, revistas e DVDs, D15 diz: "Uso quando se faz necessário e a atividade pede".

Esta fala dos professores quanto ao uso quando se faz necessário e na relação com o conteúdo, chama a atenção para dois pontos: um deles é a percepção de que não se deve trabalhar com o material por ele mesmo, mais saber pensar o potencial que existe num material específico para ajudar a desenvolver determinados conteúdos. Outro ponto é a questão da necessidade, numa visão um pouco pragmática das atividades na escola. Nem sempre vemos, ouvimos, lemos algo porque nos é útil! Muitas vezes é por fruição, pelo prazer de ler, ouvir e ver. A escola pode pensar em como se aproximar das produções culturais de forma mais lúdica, trazendo realmente a perspectiva do trabalho com múltiplas linguagens, um trabalho que seja também prazeroso e daí, do prazer, do significado e motivação despertados nos alunos, desenvolver outros aspectos, tais como análise crítica de conteúdo, relações com outros conteúdos trabalhados nas diversas aulas.

\footnotetext{
${ }^{18}$ A professora auxiliar trabalha no contra turno, em salas onde há crianças com deficiência de aprendizagem, colaborando com a professora titular.
} 
Em uma das escolas, dois professores afirmam não trabalhar com música e programas de TV, pois não há acesso aos mesmos na escola: "A escola não tem aparelho de som.” (O9) "Não temos acesso a programas de TV.” (O2)

$\mathrm{O}$ acesso a programas de TV é algo que exige reflexão. $\mathrm{O}$ professor, provavelmente, tem aparelho de TV em sua residência e assiste a vários programas. Pode conversar sobre os programas, pode gravá-los e apresentá-los em videocassete ou aparelho de DVD para os alunos. É uma questão realmente de como incorporamos a cultura eletrônica e digital que já vivenciamos no dia a dia em nossas aulas. Pesquisas realizadas por CITELLI (1997; 2004; 2010) apontam que mesmo que os professores utilizem as mídias em seu cotidiano não as traspõem para suas atividades docentes. Ainda destaca que mesmo docentes mais jovens, com um cotidiano atravessado por novas linguagens, não fazem uso recorrente das mesmas enquanto professores:

As práticas em sala de aula não parecem ter mudado substancialmente pelo fato de os jovens docentes estarem mais integrados aos circuitos de comunicação. A posse de computadores e televisão a cabo ou o acesso à internet não garantem, nas práticas do magistério, a passagem da sociedade industrial para o pólo informático-mediático. Neste aspecto, professores de diferentes faixas etárias dão continuidade a uma estrutura escolar complexa, cifrada por inúmeros problemas, que convidam à manutenção de dinâmicas propedêuticas e rotinas normatizadas que funcionam como fatores de conservação dos processos educativos formais. Existe, aqui, uma espécie de patamar comum a unir gerações diferentes de docentes. (CITELLI, 2010: 23)

As respostas dadas pelos professores a essas 8 questões iniciais nos trazem alguns elementos para reflexão. Como colocado por Citelli (2010), as práticas em sala de aula não parecem ter mudado. A caracterização dos professores pesquisados, quanto a faixa etária, gênero, escolarização e a contextualização de seus processos formativos - onde e quando estudaram - traz elementos para pensarmos a formação inicial de professores. Estes primeiros dados demonstram que os professores em trabalho nas escolas não passaram pelo exercício de escolarização do conhecimento midiático. Se a prática dos professores também é influenciada pelos processos de formação vivenciados, ao desejarmos que os professores desenvolvam habilidades comunicativas para o trabalho com mídias, é necessário que esses processos sejam trabalhados em nossos cursos de formação inicial.

Além das questões fechadas, apresentamos aos professores cinco questões abertas, que passaremos a analisar em seguida, relacionando-as, quando for necessário, às 
questões fechadas, para uma melhor reflexão sobre as percepções dos professores quanto às suas práticas docentes.

\subsection{Percepção dos professores quanto às suas práticas docentes em relação às mídias}

As questões abertas procuravam trazer à tona a opinião dos professores quanto à utilização de diferentes materiais em suas aulas, inclusive novas mídias, como computador e TV. Uma vez que a preocupação deste trabalho é com a formação de professores em relação às novas demandas colocadas por uma sociedade midiática como a nossa, as perguntas também abordavam a colaboração que as mídias podem trazer para as aulas, o trabalho ou não com programas de TV e sua relação com conteúdos de ensino, como os professores percebem o seu preparo diante do trabalho com mídias, em especial TV e computador e como entendem a relação entre educação e mídias.

Diante dos dados já apresentados e discutidos em relação aos quadros curriculares dos cursos de Pedagogia e como está proposto neles, via disciplinas, a abordagem da interface entre educação e comunicação, procuramos analisar nas falas dos professores as práticas docentes diante dos conhecimentos que construíram em seus cursos de formação inicial.

Nesta perspectiva é que analisamos os dados a seguir. O material relativo aos 113 questionários foi lido e relido, para uma imersão nas colocações dos professores e, com isso, diante do quadro teórico, pudéssemos construir algumas análises que colaborem para avançarmos na compreensão do que se faz necessário na formação de docentes num mundo perpassado por mídias como é o nosso.

Na primeira das questões fechadas, a de número nove, perguntamos aos docentes: "Por que você utiliza esses materiais e/ou recursos em aula?", fazendo referência ao quadro já apresentado na questão número oito.

Algumas falas foram muito recorrentes nas respostas dos professores, nos dando indicadores para a análise. Em geral, os professores afirmaram utilizar diferentes materiais e recursos em suas aulas como forma de despertar o interesse dos alunos e 
motivá-los, para diversificar as aulas e a metodologia, tornando o ensino mais prazeroso, para enriquecer conteúdos e despertar a criatividade na leitura. Também como forma de integrar a realidade vivenciada pelos alunos à escola.

Para facilitar a visualização de nossos leitores, apresentaremos as falas dos professores em quadro, relacionando aos recursos já apontados no quadro da questão número oito. Destacamos as falas contraditórias dos professores, que mesmo considerando que devem diversificar a metodologia e motivar os alunos, utilizam recursos como a lousa em todas as aulas e praticamente não trabalham com novas mídias, como é o caso da TV. Vejamos as falas:

Tabela 2. Diversificação de Metodologias, periodicidade e utilização de materiais

\begin{tabular}{|c|c|c|c|}
\hline Professores & Falas dos professores & $\begin{array}{l}\text { Materiais utilizados } \\
\text { nas aulas }\end{array}$ & Periodicidade \\
\hline A6 & $\begin{array}{l}\text { A diversidade de materiais torna a aula } \\
\text { mais interessante }\end{array}$ & $\mathrm{TV}$ & Nunca \\
\hline $\mathrm{P} 2$ & $\begin{array}{l}\text { Para dinamizar a aula, tornar o } \\
\text { aprendizado mais agradável, facilitar o } \\
\text { processo de aprendizagem e estimular o } \\
\text { raciocínio e a criatividade }\end{array}$ & $\begin{array}{l}\text { Lousa } \\
\text { TV }\end{array}$ & $\begin{array}{l}\text { Toda aula } \\
\text { Nunca }\end{array}$ \\
\hline $\mathrm{P} 1$ & $\begin{array}{l}\text { Para tornar a aula mais dinâmica, } \\
\text { interessante para o aluno e aproveitar o que } \\
\text { há de melhor para trabalhar os conteúdos }\end{array}$ & $\begin{array}{l}\text { Lousa } \\
\text { TV } \\
\text { Livros }\end{array}$ & $\begin{array}{l}\text { Toda aula } \\
\text { Nunca } \\
\text { Toda aula }\end{array}$ \\
\hline $\mathrm{O} 1$ & $\begin{array}{l}\text { Para diversificar o trabalho pedagógico e } \\
\text { oportunizar o conhecimento destes } \\
\text { recursos materiais para os alunos, o que } \\
\text { beneficia o processo de leitura }\end{array}$ & $\begin{array}{l}\text { Lousa } \\
\text { Computador: } \\
\text { softwares/internet } \\
\text { TV, DVDs, musicas }\end{array}$ & $\begin{array}{l}\text { Toda aula } \\
\text { Nunca } \\
\text { Às vezes }\end{array}$ \\
\hline $\mathrm{O} 4$ & $\begin{array}{l}\text { São utilizados como recurso "extra" que } \\
\text { proporcionam um melhor aprendizado, } \\
\text { contribuindo na formação }\end{array}$ & $\begin{array}{l}\text { Lousa } \\
\text { TV } \\
\text { Computador }\end{array}$ & $\begin{array}{l}\text { Toda aula } \\
\text { Nunca } \\
\text { Deixa em branco }\end{array}$ \\
\hline ME16 & $\begin{array}{l}\text { Porque acho importante utilizar outros } \\
\text { recursos além de lousa e giz }\end{array}$ & $\begin{array}{l}\text { Lousa } \\
\text { Livro } \\
\text { TV } \\
\text { Computador } \\
\text { DVDs/Musicas }\end{array}$ & $\begin{array}{l}\text { Toda aula } \\
\text { Toda aula } \\
\text { Deixa em branco } \\
\text { Deixa em branco } \\
\text { Deixa em branco }\end{array}$ \\
\hline
\end{tabular}




\begin{tabular}{|c|c|c|c|}
\hline ME2 & $\begin{array}{l}\text { Para enriquecer, motivar, prender a } \\
\text { atenção, estimular a busca pelo } \\
\text { conhecimento, a pesquisa, sair da rotina }\end{array}$ & $\begin{array}{l}\text { Lousa } \\
\text { Livro } \\
\text { TV/DVDs } \\
\text { Computador }\end{array}$ & $\begin{array}{l}\text { Toda aula } \\
\text { Toda aula } \\
\text { Eventualmente } \\
\text { Só nas aulas de } \\
\text { informática }\end{array}$ \\
\hline ME7 & $\begin{array}{l}\text { Para auxiliar o trabalho e provocar o } \\
\text { interesse pelo o que é estudado }\end{array}$ & $\begin{array}{l}\text { Computador } \\
\text { Lousa } \\
\text { Gibis/HQs/Músicas }\end{array}$ & $\begin{array}{l}\text { Nunca } \\
\text { Toda aula } \\
\text { Eventualmente }\end{array}$ \\
\hline $\mathrm{C} 8$ & $\begin{array}{l}\text { Para tornar a aula mais atrativa, mais } \\
\text { estimulante }\end{array}$ & $\begin{array}{l}\text { TV } \\
\text { Lousa }\end{array}$ & $\begin{array}{l}\text { Nunca } \\
\text { Toda aula }\end{array}$ \\
\hline M8 & $\begin{array}{l}\text { Para facilitar a aprendizagem e diversificar } \\
\text { as aulas, com o objetivo de chamar a } \\
\text { atenção dos alunos }\end{array}$ & $\begin{array}{l}\text { Lousa } \\
\text { TV/DVDs } \\
\text { Computador }\end{array}$ & $\begin{array}{l}\text { Toda aula } \\
\text { Eventualmente } \\
\text { Eventualmente }\end{array}$ \\
\hline L7 & $\begin{array}{l}\text { Esses materiais estão presentes em nosso } \\
\text { meio social, por isso busco utilizá-los com } \\
\text { os alunos para que saibam como usar e } \\
\text { desenvolvam a criticidade diante deles }\end{array}$ & $\begin{array}{l}\text { Lousa } \\
\text { Livro } \\
\text { TV } \\
\text { DVDS } \\
\text { Revistas/Jornais }\end{array}$ & $\begin{array}{l}\text { Toda aula } \\
\text { Toda aula } \\
\text { Nunca } \\
\text { Eventualmente } \\
\text { Eventualmente }\end{array}$ \\
\hline D20 & Para atividades diversificadas & $\begin{array}{l}\text { Lousa } \\
\text { Livro } \\
\text { Programas de TV } \\
\text { Revistas/Jornais } \\
\text { DVDs }\end{array}$ & $\begin{array}{l}\text { Toda aula } \\
\text { Toda aula } \\
\text { Nunca } \\
\text { Nunca } \\
\text { Nunca }\end{array}$ \\
\hline
\end{tabular}

Fonte: questionários respondidos pelos professores participantes da pesquisa

Analisando-se o quadro anteriormente colocado e a fala dos professores percebese que são recorrentes, embora tenhamos destacado falas de docentes das diferentes escolas estudadas. Mesmo sendo de escolas diferentes, os professores têm o mesmo discurso e afirmam que os recursos e materiais usados nas aulas devem servir para motivar os alunos, diversificar as aulas e as metodologias, tornar as aulas mais interessantes e próximas à realidade dos alunos. Entretanto, ao fazerem a opção pelos 
materiais utilizados por eles mesmos nas aulas, se observa a constância da utilização da lousa e do livro, que são usados em todas as aulas, mostrando que não há diversidade de materiais ou de metodologias. Os programas de TV não são usados ou são trabalhados de forma eventual. O mesmo acontece com a utilização do computador, que aparece como nunca sendo usado ou não é nem assinalada essa opção, que é deixada em branco. Outros materiais, como revistas, jornais, HQs, gibis, também aparecem sendo usados eventualmente ou nunca.

Mesmo diante da compreensão da importância de diversificar as aulas, de tornálas atrativas para os alunos, os professores parecem estar usando a mesma metodologia em todas as aulas, com uma escolha quase unânime quanto à utilização da lousa. Dentre os 113 professores pesquisados, como já dissemos, 88 afirmam usar a lousa todas as aulas, aproximadamente $80 \%$ dos docentes. Há uma incongruência entre o que dizem saber os professores e o que estão fazendo em seu cotidiano nas escolas, com os alunos.

Podemos considerar alguns aspectos para analisar esta incongruência. Um deles é a formação inicial destes docentes. Como vimos na análise das ementas e quadros curriculares dos cursos de Pedagogia da cidade de Santos, eles parecem não estar sendo preparados, em seus estudos iniciais, para o desenvolvimento e construção de novas possibilidades para suas práticas enquanto professores. Os cursos de formação continuam privilegiando uma formação voltada para a linguagem verbal e numérica, privilegiando pouco o estudo de novas linguagens, as possibilidades de experimentação e criação proporcionadas pelas novas mídias. Há pouco espaço para reflexão sobre a interface entre processos comunicacionais e educacionais nos cursos de formação docente. Este hiato traz um paradoxo: os professores sabem da importância de diversificar as aulas e até querem fazê-lo, mas não foram preparados para tal e, assim, temos como hipótese, que tem receio de inovar e talvez errar em algum momento. Resistem às próprias ideias que tem sobre a necessidade de aproximar a escola e os alunos da realidade midiática, em que todos - professores e alunos - já vivem em seus cotidianos.

Citelli nos diz exatamente isso, ao afirmar que temos uma questão para pensar quanto à forma que trabalhamos nos cursos de formação de educadores:

O sujeito-educador, saído de um instituto superior ou de algum curso para o magistério que se resumiu a prepará-lo para o trabalho com texto verbal, está, agora, diante de uma nova rede discursiva e de desafios práticos que lhe sugerem problemas 
com os quais não está em condições de operar. (CITELLI, 2004: 222)

A Lei de Diretrizes e Bases da Educação Nacional (LDB no. 9394/96), nas diretrizes propostas para o Ensino Médio, aponta nas premissas do documento que a produção contemporânea de cultura é essencialmente simbólica e que o convívio em sociedade exige o domínio das linguagens como instrumento de comunicação e de negociação de sentidos. É diante desta perspectiva que devem ser repensados os cursos de formação de professores: como locais onde se aprendam a dominar diferentes linguagens, pois são formas que temos para nos comunicar e, acima de tudo, maneiras de construirmos diferentes sentidos diante da vida. Ou seja, o domínio das linguagens, a capacidade de analisá-las e usá-las socialmente podem nos conduzir à construção de sociedades mais democráticas, onde todos tenham direito a livre expressão e a participação realmente cidadã nos processos sócio-históricos. Os professores podem e devem ser formados na perspectiva que o trabalho docente é um trabalho intelectual, que exige autonomia e capacidade crítica para avaliar seu próprio trabalho em relação aos desafios do contexto social mais amplo, sem perder de vista os objetivos da escola, sua função social de pensar e transformar a realidade.

Alguns professores apontaram problemas no acesso aos materiais e até mesmo a falta deles. O professor L8 assinala que nunca usa nenhum recurso, nem TV, DVD, música, gibis e utiliza lousa e livro em todas as aulas: "Não temos esses recursos e com classes lotadas e indisciplinadas fica difícil. A maioria dos jornais, pesquisas e leituras são lições para casa." O professor O5 corrobora essa idéia e usa lousa e livro em todas as aulas e TV e computador em nenhuma das aulas: "Uso lousa toda aula por falta de recursos disponíveis e estrutura." Esta também é a fala do professor O9: "Qualquer mídia, bem focada, é boa para o desenvolvimento geral do aluno e do conteúdo a ser trabalhado. Porém, essa escola não privilegia seu uso.” Afirma usar lousa em todas suas aulas e que na escola não há aparelho de som, nem revistas nem acesso a DVD.

Outro importante aspecto a ser pensado refere-se à importância de que os professores precisam ter acesso às novas mídias na própria escola, se a intenção é de que eles realizem um trabalho que as tenha como um dos eixos formativos. Um trabalho que leve em conta a educomunicação pode estar explícito nos projetos pedagógicos das escolas, sendo gerenciado por toda a comunidade escolar, inclusive pelos órgãos gestores externos, caso das Secretarias de Educação. 
No caso das escolas do município de Santos, elas recebem os DVDs do programa federal do Ministério da Educação, "Projeto DVD Escola". Entretanto, alguns professores dizem não ter acesso ao material. Há um descompasso evidente entre um caminho que já se sabe que é preciso percorrer - pois está explícito inclusive em documentos oficiais - e o que acontece cotidianamente nas escolas e nas aulas. Os órgãos gestores das políticas públicas de ensino podem ser catalisadores destas discussões quanto ao proposto e ao real vivido nas escolas, colaborando na articulação entre a formação inicial de docentes e as propostas pedagógicas das Secretarias de Educação, como também proporcionando momentos de formação continuada aos docentes em exercício.

Ainda quanto à questão nove, aparecem falas não recorrentes, mas que é interessante destacar. Nos trabalhos em educomunicação, alguns eixos são fundamentais. Um deles é trabalhar a criticidade dos alunos diante da recepção aos produtos midiáticos, construindo uma capacidade de leitura, análise e compreensão que caminhe no sentido de práticas cidadãs diante dos processos culturais. Um único professor, dos 113 pesquisados, tem uma fala neste sentido. O professor D5 afirma que é preciso variar os materiais nas aulas "para incentivar os alunos a pensarem, questionarem, terem opinião crítica." Mesmo diante desta colocação, é interessante observar que ele mesmo permanece usando a lousa e o livro em todas as suas aulas e usa, eventualmente, programas de TV, gibis e música.

É essencial que os professores, inseridos numa sociedade perpassada por mídias, numa cultura videotecnológica, façam a mediação dos artefatos midiáticos, colaborando para o desenvolvimento de uma leitura mais crítica dos seus alunos. Além das funções da escola tradicionalmente reconhecidas, como trabalhar junto aos alunos com os conhecimentos construídos e acumulados pela humanidade, o desenvolvimento da socialização e da capacidade argumentativa, dentre outras, é importante que se pense em novas demandas quanto ao papel dos docentes e da escola nas sociedades contemporâneas. É preocupante que um único professor explicite, claramente, a necessidade de fazer com que os alunos pensem, questionem e formem uma opinião crítica diante dos conteúdos veiculados pelas mídias e mais preocupante ainda é que mesmo pensando na criticidade, ele tem limitações para colocá-la em prática, na medida em que usa em todas as suas aulas a lousa e o livro enquanto materiais de apoio e leitura de mundo. Ressalto que essas análises não pretendem, em nenhum momento, 
culpabilizar os professores. Penso que devemos focá-las em como estamos formando nossos professores, em quais ambientes, vivenciando quais experiências. Se os professores não explorarem, refletirem e construírem propostas em seus processos de formação inicial para o trabalho com mídias, terão enormes dificuldades para desenvolver esse trabalho em seus cotidianos junto aos alunos.

Outro aspecto essencial na interface entre educação e comunicação é a superação da compreensão de que as mídias são simplesmente recursos técnicos. As novas mídias apresentam novas linguagens, a construção de novos significados e sentidos. Um único professor aponta este aspecto em sua resposta, dizendo que varia os recursos "para oportunizar o reconhecimento das diversas linguagens." (ME6).

Nas palavras de Ismar Soares:

Confrontos entre, de um lado, o mundo da comunicação/suas tecnologias e, de outro, o universo da educação/suas didáticas permaneceram tão arraigados, por tanto tempo, que a sociedade não se deu conta da necessidade de formar os educadores para dominar as linguagens produzidas socialmente na construção da cultura contemporânea. (SOARES, 2011: 19)

Os cursos de formação inicial precisam garantir que os futuros educadores dominem os conhecimentos sobre a cultura midiática, que estejam familiarizados com as diferentes tecnologias e suas linguagens, para que façam uso delas e para que saibam ajudar seus alunos a pensarem sobre as mesmas, utilizando-as de forma a construírem uma sociedade mais inclusiva e igualitária. Bem como as condições estruturais das escolas precisam favorecer o trabalho dos docentes. Escolas que tenham os equipamentos necessários para um trabalho educomunicativo, com utilização também de novas tecnologias. Escolas que privilegiem a construção de espaços de diálogo entre os sujeitos, onde se possa criar, debater e sentir prazer na permanência cotidiana.

Outra idéia que aparece em algumas respostas dos professores é a de que os materiais e recursos podem ser utilizados em função de conteúdos já determinados. Parece não haver uma compreensão de que estudar as linguagens e formatos próprios das mídias já é, em si, um conteúdo exigido pela atual sociedade midiática. Não falamos mais em estudar somente os conteúdos, analisá-los criticamente, nem mesmo de simplesmente usar a TV ou o computador como suportes ou recursos, de forma meramente técnica. Estamos falando da necessidade de se trabalhar na escola com a dimensão das novas linguagens, de forma a permitir a constituição de novas criações. Novas linguagens que trazem formas de comunicação diferentes, com as quais estamos 
aprendendo a conviver diariamente, que tem impactado nossos relacionamentos sociais, para além da própria escola. O trabalho com novas mídias, com novas formas de comunicação que atravessam nosso campo cultural atual, trazendo-lhe novas configurações, também deve permitir que crianças e jovens expressem-se livremente, que construam e reconstruam significados para suas próprias vidas. Que ao estudar as novas linguagens nas escolas possam se assumir como produtores culturais, possam não só analisar criticamente os conteúdos veiculados nas mídias, mas que possam propor novos conteúdos, novas formas de expressão, que os conduzam a uma participação mais efetiva na sociedade na qual estão inseridos, da qual são protagonistas. Pensar em práticas educomunicativas é pensar no aluno que temos hoje em nossas escolas, com todos os anseios e sonhos que sem dúvida estão vinculados às formas com as quais convivemos nas sociedades contemporâneas.

Retomando a análise do questionário respondido pelos professores, na questão dez abordamos a questão da utilização de programas de TV como forma de colaborar com as aulas. Dos 113 professores, 76 responderam que os programas de TV podem colaborar com as aulas; somente três deles pensam que não pode haver nenhuma colaboração. Visualizamos os dados no gráfico a seguir:

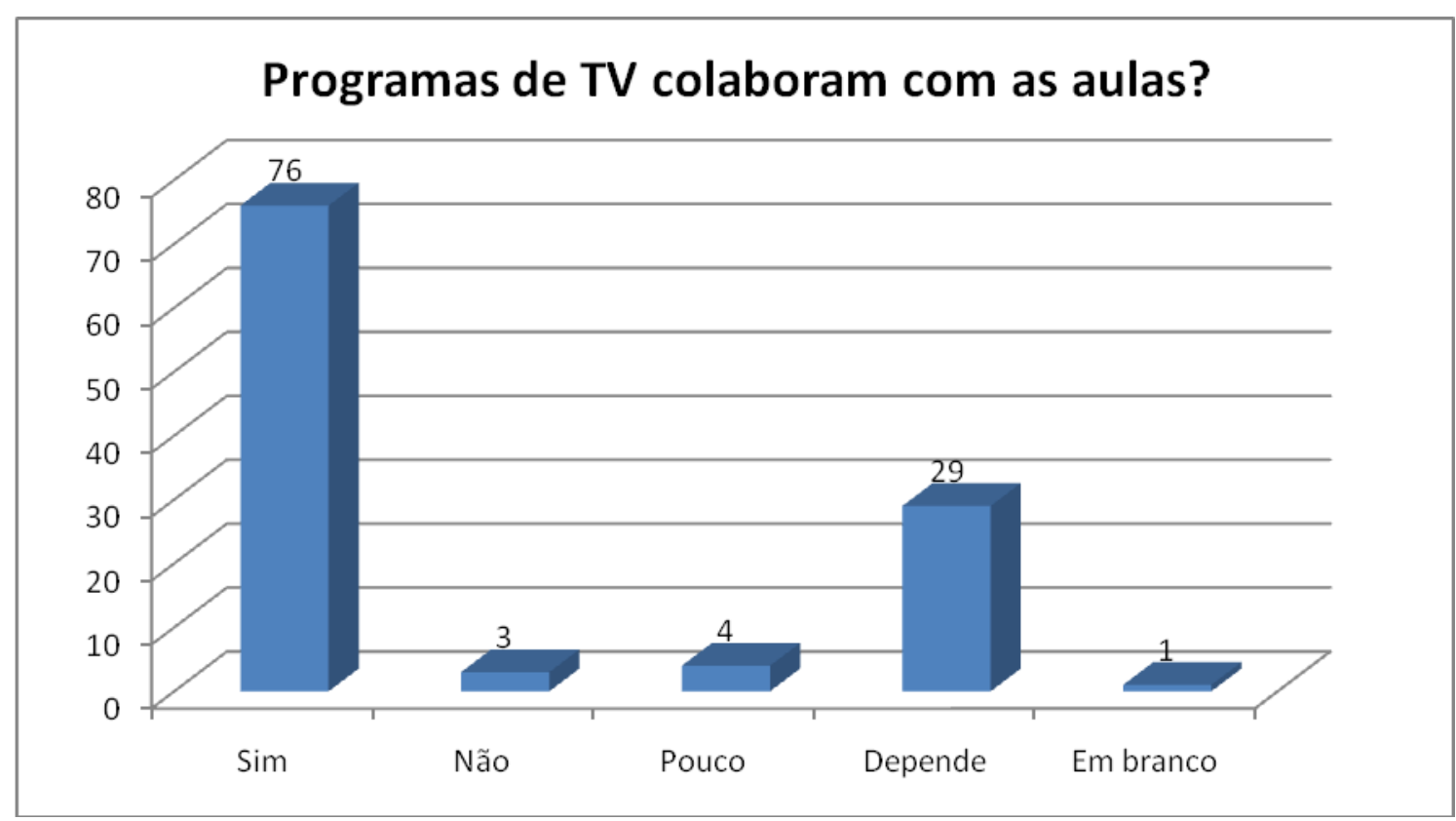

Gráfico 11. Programas de TV colaboram com as aulas? 
Quanto aos indicadores nesta questão, aparece de forma recorrente que os programas de TV podem ser usados para ilustrar e ajudar os alunos a fixar os conteúdos trabalhados nas aulas. Essa é a fala do professor P11: "Sim, para melhor fixação e apreensão dos conteúdos." Também é a fala do professor L12: "Sim, desde que o assunto vá ao encontro do conteúdo que está sendo trabalhado."

Junto a esta ideia de ajudar com os conteúdos, aparece também a relação dos temas veiculados na TV com a realidade vivenciada pelas crianças na sociedade. Vejamos duas falas de professores: "Sim, pois documentários e reportagens aproximam as crianças mais da realidade e mostram também, alguns gêneros, uma visão científica." (D3) “Sim, desde que tenham relação com o conteúdo trabalhado. Podem ser documentários ou alguns desenhos." (C7)

Interessante destacar que não aparece nas falas dos professores que uma ideia seria partir do interesse das crianças, daquilo que elas mais assistem e que, portanto, traz significados e leituras de mundo para elas. Nesse sentido, as respostas dos professores nos fazem pensar sobre currículo e conteúdo. Como esses professores, que afirmam em vários momentos que devem trabalhar os conteúdos, pensam a respeito desse mesmo conteúdo? Quem, afinal, determina os conteúdos trabalhados em nossas escolas? Enquanto professores, não temos a tarefa, dentre outras, de estabelecer em conjunto com nossos pares, o que trabalharemos, de que forma, para qual objetivo?

A fala do professor D1 traz uma indicação quanto à cobrança dos conteúdos que é feita aos professores: "Só mesmo os educativos, pois a cobrança com os conteúdos e a programação da escola não nos deixa muito livres. (D1)

Este é um dado importante para reflexão. Este pensamento dos professores, quanto a não estarem livres para desenvolver seu trabalho, nos remete aos cursos de formação docente e a própria configuração de nossos sistemas de ensino, que muitas vezes engessam o trabalho dos professores, não dialogando com os mesmos sobre suas reais necessidades e anseios, inserindo-os na elaboração e implementação de propostas e projetos para as escolas, para que possam opinar e para que, efetivamente, a construção da proposta pedagógica das escolas seja feita de forma coletiva.

Ainda nessa questão, a número dez, aparece em várias falas dos professores, que se pode trabalhar com programas de TV desde que sejam programas educativos ou ligados a assuntos pensados como sendo pertinentes a escola e seu universo. É o que nos diz o professor D 11: "Sim, desde que educativos e próprios para a idade." 
O que serão programas educativos? Magalhães realizou um estudo sobre os programas infantis da TV e traz uma interessante contribuição para se pensar essa questão:

O engajamento não é feito de forma mecânica, e a criança não estará, necessariamente, interagindo de forma determinada ou esperada pelos produtores do projeto somente ao se expor ao programa educativo. (...) Assim como os demais (e complexos) fatores que envolvem a aprendizagem, o programa é mais um fio a se mover (e ser movimentado). A diferença entre esse fio e o fio pelo qual passam programas como o TV Xuxa ou Cocoricó não está no seu movimento e na sua extensão, mas na sua qualidade, considerada como a sintonia e as interrelações e interações provocadas entre a criança e os demais fios da malha que a cerca, e que está integrado de forma conjunta e harmoniosa com a trama social. (MAGALHÃES, 2007: 50-51)

O que torna um programa "educativo" é muito mais do que o programa em si. É a forma como este programa dialoga com outras experiências vivenciadas pelas crianças, inclusive aquelas que podemos mediar, enquanto educadores, em nossas escolas, nas aulas. A compreensão e releitura dos programas dependem muito mais dessa mediação do que aquilo que o programa apresenta para a criança.

A escola pode e deve trabalhar com todos os programas de TV e seus conteúdos, pois já fazem parte do universo das crianças e dos adolescentes. Aliás, já fazem parte também do universo dos professores! Interessante notar mais uma vez certo paradoxo nas respostas dos professores. Embora 76 deles achem que a TV e sua programação podem colaborar com as aulas, não percebem todas as possibilidades e amplitude da linguagem televisual. Ficam presos a trabalhar com programas que estejam de alguma forma ligados aos conteúdos já estabelecidos como aqueles que devem ser trabalhados nas escolas, na educação formal. A escola tem, entre seus papéis, o preparo das novas gerações para o convívio social, para a apropriação de conhecimentos acumulados pela humanidade e logicamente não deve abrir mão dessas funções. Mas não pode se furtar a pensar em novos papéis, na medida em que temos outras exigências sociais hoje, nos pautando mediações docentes diferenciadas. Podemos pensar em como articular as funções tradicionais da escola às novas demandas, sendo capazes de diálogos com a cultura contemporânea midiática.

Ainda cabe destacar que os professores falam em usar a TV como forma de aproximar os alunos da realidade. Isso nos faz pensar em como vêem a realidade ou o que será realidade para os professores. Os conteúdos que estão propostos nos 
parâmetros curriculares oficiais ou nos livros didáticos adotados pelas escolas não são reais, não falam da realidade que vivemos? Será que, intuitivamente, os professores sabem que há um descolamento entre os conteúdos trabalhados nas escolas e a realidade vivida pelos alunos? Ou ao menos que há um descolamento entre os anseios dos alunos e como a escola e os professores vêm tratando destas questões no dia a dia das instituições?

Alguns professores ainda citam que a escola deve trabalhar com a programação televisual para que os alunos saibam o que é bom ou não é. Apontamos algumas das falas docentes: "Sim. Mesmo aqueles que consideramos prejudiciais, podem ser discutidos (valores, etc.)." (M14). Outro professor diz: “Sim, apenas para discussão sobre valores positivos e/ou negativos e relacionar com os conteúdos." (C9) Também é o que aparece nesta fala: "Em certas discussões sim; pode servir de instrumento de análise do que é positivo e negativo para o conhecimento.” (ME 2)

Os professores parecem demonstrar estar mais preocupados com os conteúdos veiculados na TV do que em discutir com os alunos também o formato da produção, a especificidade da sua linguagem. Importante trabalhar criticamente as mensagens veiculadas na mídia e compreender também as particularidades das diferentes linguagens, considerando o que é possível trabalhar em cada faixa etária, em função do desenvolvimento dos alunos e de sua capacidade de absorção e análise da realidade. Este trabalho com a criticidade e com a diversidade de linguagens é um ponto a ser considerado nos cursos de formação de professores. Trabalhar todo o potencial que pode ser explorado no trabalho com mídias, para muito além das análises de conteúdo, embora sem dúvida, estas sejam fundamentais para construção de um senso crítico mais apurado. Entretanto, é importante, como já consideramos em outros pontos deste trabalho, que os professores também sejam preparados para trabalhar com a forma dos diversos programas, que entendam sobre os diversos gêneros de produção. Os alunos, cidadãos de uma sociedade midiática, devem aprender a pensar na linguagem televisual, na linguagem digital. Compreender a edição do programa, a forma de produção e circulação da informação. Só assim, podem ampliar a sua própria capacidade de serem produtores sociais de comunicação com mídias, aptos a criticar programas, aptos a construir programas, aptos a perceber como a música inserida num programa procura construir um determinado significado, como uma cor utilizada quer construir uma determinada ideia, como o plano da câmera constrói um sentido e assim por diante. 
Cursos de formação docente para que os professores entendam e possam trabalhar com múltiplas linguagens, cada vez mais convergentes entre si, cada vez mais sofisticadas e que só podem estar a serviço da construção de uma sociedade mais democrática se aprendermos a utilizá-las, a dialogar com elas, a construir novos significados a partir das inúmeras possibilidades que nos oferecem.

Retomando as questões, a de número 11 estava formulada assim: "Nas suas aulas você tem por hábito sondar quais programas televisivos seus alunos assistem?” ( ) sim; ( ) não; ( ) às vezes. Se a resposta for sim ou às vezes, você discute com eles a programação assistida? Relaciona com os conteúdos do ensino?"

Dos 113 professores questionados, 42 afirmam que sim, 07 respondem não e 63 respondem às vezes, como podemos ver no gráfico apresentado em seguida:

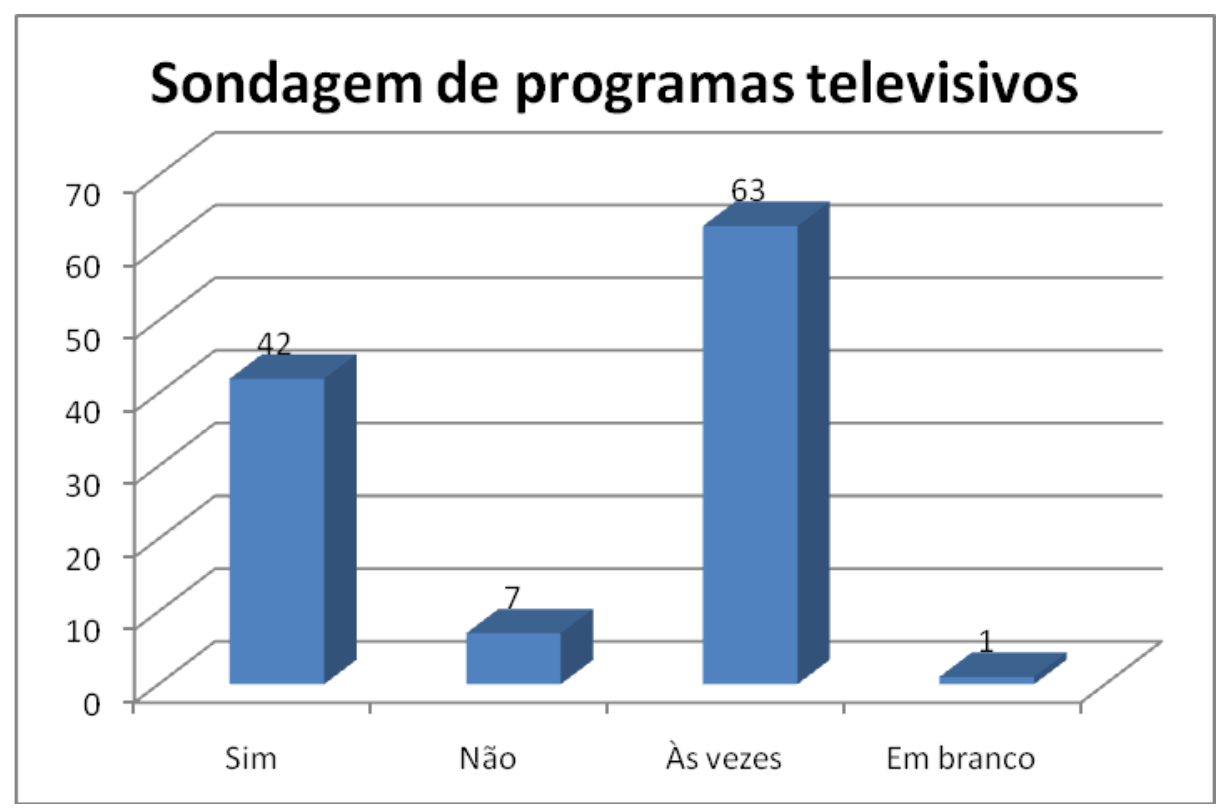

Gráfico 12. Sondagem de programas de TV pelos docentes

Relacionando a questão anterior com esta, aparece algo interessante para a nossa reflexão. Ao serem questionados se os programas de TV podem colaborar com as aulas, 76 dos professores dizem "sim”. Entretanto, logo após, são questionados se conversam com seus alunos sobre os programas que estes dizem assistir mais e o número de respostas vai para 42 respostas "sim”. Interessante perceber que os professores sabem da importância de sondarem a programação da TV, de conversarem com seus alunos sobre essa mesma programação, mas parecem não assumir efetivamente a mediação diante dessa programação! Se há uma centralidade da mídia enquanto constituidora do 
campo cultural e de seus significados em nossa sociedade, há, sem dúvida, um papel a ser desempenhado pela escola e pelos professores, também criadores de cultura e construtores de significados diante da vida e do mundo. A escola pode ser um espaço de interlocução com outras instâncias culturais da sociedade, trazendo possibilidades de criação e recriação de sentidos diante das produções culturais sociais, principalmente as perpassadas pelas mídias.

BELLONI (2009) nos fala sobre o papel da TV e sua programação como momento de criação e circulação de conteúdo que crianças e jovens usam nas suas formas de interação social. Os conteúdos fornecidos pela TV são apropriados e reelaborados pelas crianças a partir de suas experiências. Sendo assim,

O papel da televisão no processo de socialização será mais ou menos determinante segundo as diferentes formas de relação das crianças com o meio, a maior ou menor importância da ação dos outros atores, e o acesso a outras referências culturais. (Belloni, 2009: 35)

O papel de outros atores, tal como os professores, pode colaborar para que a apropriação e reelaboração dos conteúdos da TV aconteça articulada às experiências vivenciadas na escola, a valores discutidos no cotidiano escolar. Pode colaborar para uma apropriação mediada, onde os significados estão construídos em processos dialógicos e não somente aqueles trazidos pelos grandes conglomerados econômicos que são os financiadores de inúmeros programas de TV, das propagandas veiculadas nesses mesmos programas.

$\mathrm{Na}$ mesma questão, perguntados se discutem com os alunos a programação assistida e se relacionam ao conteúdo trabalhado em suas aulas, as respostas são: 72 respondem "sim"; 07 "não"; 23 "às vezes" e 11 deixam a resposta em branco, como podemos ver no gráfico a seguir: 


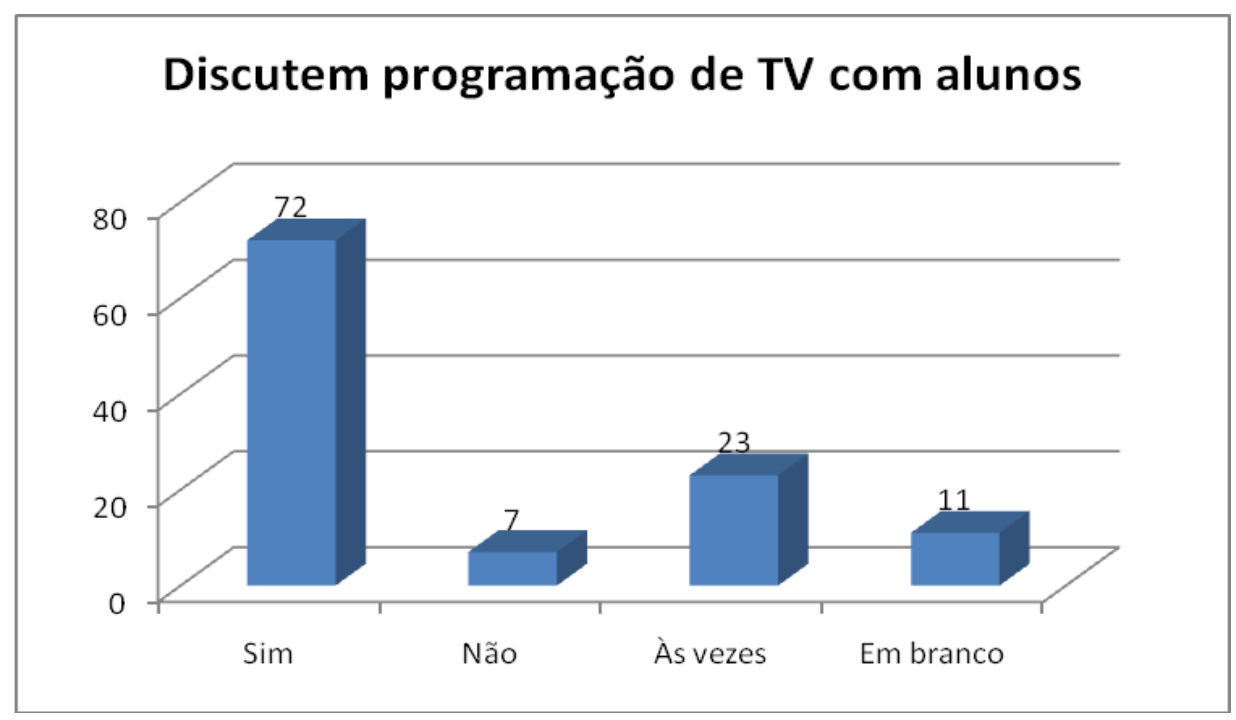

Gráfico 13. Professores e discussão de programas de TV com alunos

Aparece de forma recorrente a ideia de que só é possível discutir os programas com os alunos se eles forem programas educativos, como já vimos em análise de questão anterior. Vejamos algumas falas: "Não, porque raramente eles assistem a programas educativos." (A8) "Sim, principalmente aqueles das TVs educativas." (O11) "Mando que eles assistam TV Cultura, Futura e que peçam permissão dos pais para assistirem algum tipo de programa." (ME 14)

Magalhães (2007) faz uma reflexão sobre o que seriam programas educativos, discutindo-os a partir de algumas características e das idéias-chave da interrelação entre educação e comunicação e da dialogicidade entre a criança e outros atores sociais. Assim, um programa seria educativo em função da "natureza do processo de interação com a criança, respeitando sua sintonia com a malha social em que está inserida". (MAGALHAES, 2007: 50)

Ou seja, o que pode tornar a experiência significativa para a criança, diante da programação assistida, não é a programação em si, mas como ela é apropriada pela criança, considerando suas próprias vivências, a sua interlocução com outras pessoas, em ambientes nos quais está inserida. Ou seja, a mediação exercida por outras pessoas, pais e professores, abre possibilidades de diálogo sobre o que foi visto, abre possibilidades de releitura e de outras formas de apropriação do conteúdo apresentado. Enquanto professores, podemos dialogar com nossos alunos sobre qualquer programa de TV, sobre qualquer site, sobre qualquer outro artefato cultural, pois não é o conteúdo em si, sozinho, que constrói o sentido, mas toda a rede de significados. Não há uma 
construção de significado somente no momento da recepção; há uma rede de mediações, tecidas dentro de contextos sociais, onde acontecem processos de comunicação da emissão para a recepção, mas também da recepção para a emissão, onde todos os atores, em algum momento, são emissores, construindo sentidos a partir de suas próprias leituras. É nesse sentido que a escola pode atuar: sendo um espaço nessa rede de mediações, propiciando diálogos constituidores de sentidos, trazendo reflexões sobre as produções culturais midiáticas, assumindo-se como construtora de cultura, como produtora social de comunicação. Esse é um papel a ser exercido por professores numa sociedade como a nossa, que tem como um dos eixos de sua cultura, as produções midiáticas eletrônicas e digitais, trazendo uma constituição do tecido social atravessada pela tecnologia e pelas diversas linguagens expressas nessas tecnologias.

Ainda que a maioria dos professores responda "sim" ao ser questionada se discute os programas de TV e relaciona-os com os conteúdos, aparecem duas situações. Uma delas é apresentar a resposta 'sim" de forma seca, sem nenhuma argumentação, sem nenhuma colocação. Simplesmente "sim" e não se posicionam mais. A outra situação é a afirmação de que é preciso relacionar com o conteúdo da escola, das disciplinas. Parece existir uma compreensão dos professores de um conteúdo prescrito, a ser dado e que os programas de TV são um complemento, um recurso extra, que pode facilitar a aprendizagem dos alunos quanto aos tais conteúdos já prescritos. A discussão sobre aspectos comunicacionais com mídias na escola vai muito além da ideia de recursos e de complementar os conteúdos. Há uma especificidade das linguagens das novas mídias, uma especificidade da forma e conteúdo da TV, do computador, que não são recursos para um conteúdo, já são o conteúdo em si mesmo. Estudar a linguagem específica das novas mídias, estudar as possibilidades de criação e recriação a partir dessas linguagens já é um conteúdo. Não basta ensinar sobre a Amazônia para os meninos e então mostrar um documentário sobre o Amazonas ou um programa de reportagem. É preciso mostrar realitys show para os meninos, para que eles percebam a edição que é feita, o porque tal música é colocada, o porque de uma cor no programa e não outra.

É preciso que os meninos entendam como é produzida a informação, qual a sua forma de circulação, qual seu objetivo. Também é preciso que os meninos se sintam capazes de construir conteúdos, a partir de suas realidades locais. Que, por exemplo, se moram em área degradada de mangue, sejam capazes de olhar para o local, pensar sobre 
ele, tomar uma câmara nas mãos, filmar o local, apresentá-lo para a comunidade, discutir seus problemas e anseios também a partir de suas produções comunicacionais com mídias, com todas as possibilidades que as novas tecnologias nos apresentam. Temos aberto hoje um cenário que nos permite experimentações, novas criações e que podemos explorar enquanto educadores, enquanto pessoas que fazem parte de processos de criação de cultura, de construção de sentidos. Enquanto pessoas que dialogam umas com as outras, em sociedade, buscando novos caminhos para uma convivência mais justa, solidária e fraterna. Para que os professores possam exercer essas mediações necessitamos de cursos de formação que os preparem para essas realidades, além de escolas que contem também com uma estrutura que permita o trabalho dos docentes. Mesmo que possamos considerar difícil estas novas formas de mediação, ao pensarmos em nossas sociedades midiáticas, evidencia-se a urgência de repensarmos a formação inicial de professores.

Retomando a análise das questões, vejamos o que foi perguntado na de número doze. Para pensarmos sobre como os professores se sentem em relação ao trabalho com mídias, a questão dizia: "Você se sente preparado para o trabalho com mídias, tais como TV e computador? Explique sua resposta."

Dos 113 professores, 49 afirmam se sentir preparados, 42 não se sentem, 21 professores respondem “às vezes” ou “depende' e 1 professor não responde. Para melhor visualização, apresentamos o gráfico a seguir:

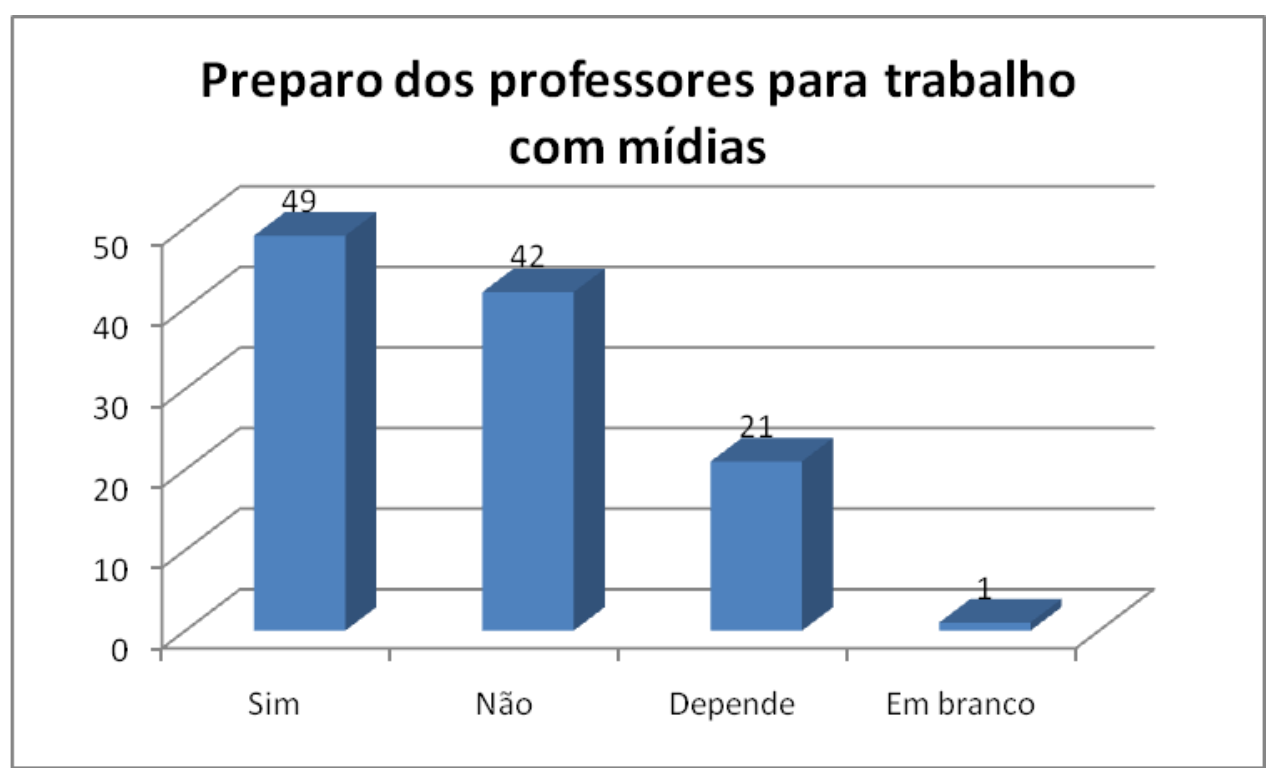

Gráfico 14. Preparo dos professores para trabalho com mídias 
Ao responderem que se sentem preparados para o trabalho com mídias, os professores usam alguns argumentos. Entre eles, a questão da atualização dos métodos, como nos diz o professor O3: "Sim, pois são emergência dos tempos e para que se possa atingir o aluno de hoje há necessidade de atualizar-se o método."

O professor $\mathrm{O} 4$ completa essa idéia, ao dizer que computador e TV são os dois maiores meios de comunicação na atualidade: "Sim, pois hoje são os dois maiores meios de comunicação sendo impossível deixá-los de fora da sala de aula."

Vários professores afirmam já utilizar as mídias diariamente em sua vida: "Sim, já tenho o hábito de usar esses meios." (O8) "Sim, também utilizo." (O10) "Sim, utilizo bastante estes recursos para preparar as aulas e me atualizar." (P1) "Sim, uso computador frequentemente e acredito na força da mídia favorecendo a educação".

Embora estes professores digam usar computador diariamente e considerem as novas mídias como canal importante de comunicação na atualidade, na questão de número oito, ao serem questionados sobre quais materiais usavam em suas aulas, a maioria deles afirmou usar lousa e livro em todas as aulas e raramente ou nunca, programas de TV e computador. Esse aparente paradoxo permeia as respostas dadas pelos professores às questões apresentadas na pesquisa. Embora reconheçam a importância das mídias para a sociedade atual, reconheçam que é preciso que a escola dialogue com a TV, com o computador, embora reconheçam e afirmem em suas respostas que é preciso motivar os alunos, discutir a realidade, este reconhecimento está mais no nível do discurso do que no nível prático. Sabem a importância, mas eles mesmos dizem não usar o recurso em suas aulas, sabem a importância, mas dizem não discutir os programas com os alunos. Este paradoxo pode ser analisado a partir de diferentes aspectos, mas um deles que é importante ponderar é o peso da cultura profissional, ou seja, o peso que tem aquilo que construímos, em nossas representações e ideias sobre a profissão, sobre quais são as formas corretas de agir, quais as melhores maneiras para enfrentar os desafios de nossa profissão. Sem dúvida, um dos locais onde construímos nossas ideias sobre a profissão docente são os próprios cursos de formação inicial de professores. Nestes cursos conhecemos e entramos em contato não só com os conteúdos conceituais, mas também entramos em contato com o que se constituiu, ao longo dos tempos, como a cultura da profissão docente. 
Como já destacamos no capítulo anterior, há, ainda, fortemente presente em nossos cursos de formação, a ideia do trabalho como transmissão de conteúdos, conteúdos que estão organizados em livros, de forma linear e sequencial. Há uma insistência com aprendizagens focadas em linguagem verbal e matemática. Há uma insistência em questões mais teóricas do que práticas, onde a palavra escola pouco aparece nas ementas das diversas disciplinas de cursos de formação espalhados por todo o país. Sendo assim, podemos pensar que professores formados em cursos que não valorizam em suas atividades cotidianas o trabalho com novas mídias, com possibilidades de experimentação e criação em novas linguagens, não se apresentarão nas escolas e trabalharão de formas inovadoras, porque não foram preparados para isso, embora utilizem as mídias todos os dias em suas vidas cotidianas. Nas palavras de Franco, "há que se desenvolver nos processos formativos uma prática crítica do saber instituído" (FRANCO, 2008: 115). Em nossos cursos de formação inicial podemos criar tempos e espaços que favoreçam o debruçar-se sobre as práticas que já existem, sobre as situações concretas vivenciadas nas escolas, para que, a partir das reflexões contextualizadas, possam surgir alternativas, novos saberes e práticas. Cursos de formação que proporcionem o exercício do pensar e do falar, formando professores que se posicionem, que assumam ideias e aprendam a trabalhar com essas ideias de forma coletiva. Nas palavras de Franco:

Para mudar a lógica das práticas, será preciso que os educadores assumam o projeto de autonomia da escola, na busca de que os 'eus' dos professores falem, que esses 'eus' reivindiquem uma nova escola, fruto das necessidades históricas e dos anseios de todos os educadores de nosso tempo. (FRANCO, 2008: 118)

Continuando nossa análise de como os docentes percebem suas práticas, os 42 professores que responderam não estar preparados para o trabalho com mídias e os 21 que dizem que depende da situação, trazem como aspecto recorrente o fato de não serem capacitados para o trabalho e, portanto, não dominarem as formas de uso. Vejamos algumas respostas: "Sim e não. Sim porque são rotineiros em minha vida, e não porque precisaria de cursos voltados a tais metodologias educativas." (O6) "Não completamente, por minha própria limitação. Não fez parte de minha formação.” (ME6) "Para trabalhar com computador, para trabalhar melhor, eu deveria ser capacitada (curso oferecido pela SEDUC)" (C8) 
Vários professores apontam que não se sentem preparados para o trabalho com mídias e destacam a questão de cursos de capacitação. "Não muito preparada, pois sinto falta de cursos de capacitação sobre o tema. Além disso, não é sempre que esses recursos estão disponíveis na escola." (C7) “Às vezes, gostaria de ter formação a respeito do assunto e sugestões." (L6) "Não completamente porque não temos cursos de especialização na área e fazemos o que pensamos ser melhor." (O17) "Estou ansioso pelo uso desses recursos, mais tecnicamente falando, não me sinto preparado não, preciso de capacitação." (A2) "Não. Faltam políticas neste sentido (formação e acesso do educador)" (O5)

As falas dos professores são bastante claras quanto à falta de formação para trabalho com mídias. Parece existir uma vontade de utilizar, mas sem preparo sentem-se inseguros. Como afirma Esteve (1995), há uma mudança de cenário, mas não se preparam os atores! Os professores reconhecem as mídias e sabem que é necessário atualizar-se. Falta que o preparo dos professores efetivamente ocorra, em cursos de formação inicial e formação contínua. Que as políticas públicas sejam efetivamente colocadas em ação!

Belloni apresenta duras críticas a um sistema de ensino que resiste à inovação e reafirma a importância da formação de professores:

Evidentemente, as variáveis do contexto (condições de trabalho, salário, mobilidade dos professores) explicam em grande parte esta inércia pedagógica que assola nossas escolas públicas. Acreditamos, todavia, que, em que pese seu valor heurístico, estas variáveis não são suficientes. Para compreender e explicar esta situação será necessário buscar subsídios na análise mais aprofundada das variáveis intrínsecas do processo educacional: a formação dos professores e, relacionada com ela, a produção do conhecimento pela pesquisa educacional e a influência ideológica das grandes teorias sociais no campo teórico e prático da educação. (BELLONI, 2009: 89)

Não basta desejar que os professores usem novas metodologias, que os projetos pedagógicos das escolas estejam articulados com as mudanças sociais e culturais que vivenciamos nas sociedades contemporâneas. Os professores precisam estar formados para dialogarem com essa nova constituição do tecido social, perpassada por tecnologias eletrônicas e digitais.

As tentativas de inovação metodológica (...) tem se chocado com a resistência dos professores que, apesar do discurso inovador ou construtivista, não transformaram em quase nada sua pratica pedagógica efetiva e continuam a ser formados para 
repetirem velhas pedagogias, quase sempre sem novas tecnologias. (BELLONI, 2009: 92)

Formar os professores considerando o desafio da mediação, da necessidade de problematização e aproveitamento de aprendizagens extraescolares por parte da escola, no que OROZCO (2009) chama de processo de reconversão educativa, como já citamos no capítulo anterior. A formação de professores pode preparar os educadores para o trabalho com produtos da TV e do computador, discutindo valores, discutindo modelos de ser humano que nos são apresentados nos diversos programas e sites. A reconversão educativa, o trabalho com a produção cultural existente na sociedade, pode colaborar para o desenvolvimento de novas formas de trabalho nos processos de ensinoaprendizagem. Podemos pensar em como formar professores que se percebem e se assumem como investigadores, em pesquisas cotidianas, sobre e na sua própria prática docente, trazendo perspectivas diferenciadas para os processos educacionais e escolares. Educadores que compreendem a investigação como forma de aprendizagem, tanto dos docentes como dos alunos.

Gostaria de citar uma fala que aparece nos questionários, que mostra que a atividade de pesquisa colabora para um deslocamento do professor:

“Computador, sim! TV... esse questionário está mexendo comigo... Respondi na tabela que nunca trabalho com telenovelas, mas, na questão 11 , vi que já conversei sobre... Aiii!" (L7)

A professora assume que o simples fato de responder um questionário para uma pesquisa está mexendo com ela, com seu pensamento, com a forma como vê seu próprio trabalho! Nossos cursos de formação podem assumir esta dimensão, de espaço para reflexão, de questionamento, de perceber os próprios paradoxos, um espaço que nos conduza a construção de práticas docentes mais articuladas com a sociedade contemporânea e suas múltiplas linguagens.

Voltando aos dados do questionário, na questão 13, perguntamos aos professores: "Como você entende a relação entre mídias - TV e computador - e o trabalho com educação?", para uma compreensão maior de como os docentes percebem esta relação. Algumas respostas foram recorrentes, nos trazendo indicadores para a análise. Uma das ideias mais apresentadas pelos professores foi a de que os alunos já usam estas mídias, já fazem parte de um mundo com estas tecnologias e que, portanto, a escola não deveria se ausentar de trabalhar com elas. 
O professor A2 nos diz: “É um recurso muito válido na educação, pois hoje em dia as crianças (quase todas) têm acesso à informática." Outro professor corrobora esta ideia: "Entendo como interessante, pois os mesmos estão inseridos no mundo digital." (A7) O professor C6 aponta a questão da atualização da escola: “A escola deveria ser mais próxima nessa relação, pois a escola 'demora' para se atualizar e os alunos já estão em outra fase, mais moderna e atualizada".

Diversas pesquisas confirmam a relação entre os jovens e a cultura digital. Dados de uma pesquisa da Fundação Telefônica, de $2009^{19}$, com abrangência em toda América Latina, demonstram que os jovens buscam caminhos de expressão e comunicação, utilizando, dentre outros meios, a Internet, através de blogs e sites. Entretanto, os dados do Brasil apontam que os professores não trabalham com a Internet nas escolas:

Entre os resultados apontados, fica explícita, por exemplo, a ausência de preocupação da escola com a cultura digital: um em cada dois estudantes brasileiros - ou seja, $50 \%$ da amostragem - diz que nenhum professor utiliza a Internet para explicar matéria ou estimula o uso da rede. Um total de $60 \%$ dos estudantes brasileiros afirma que acessa a Internet em lan houses, e não na escola ou em casa; enquanto $46 \%$ deles encontram-se absolutamente sozinhos diante do computador, sem qualquer assistência dos adultos." (SOARES, 2011:26)

Estes dados, de ausência de mediação dos adultos em relação ao que é visto pelas crianças e jovens nas telas da TV já aparece em nossa pesquisa de mestrado (BATISTA, 2005), onde $75 \%$ dos professores nada conversam sobre TV e sua programação com seus alunos. O papel do professor está sendo redimensionado com as novas tecnologias. A tarefa de passar informações pode ficar com os bancos de dados, com os livros, vídeos, mas ainda é o professor que pode aprender a produzir comunicação com seus alunos como telespectadores, aguçando-lhes a curiosidade, levando-os a pesquisar, a querer conhecer e elaborar sua participação no mundo contemporâneo, também por meio das novas linguagens, das novas formas de expressão que nos são permitidas pelas mídias presentes em nossa sociedade.

Outra ideia que transparece nas respostas dos professores a questão 13 é relativa a uma educação que deve estar integrada com a realidade e por isso deve trabalhar também com mídias. O professor O18 fala: "Necessários, pois fazem parte da vida atual

\footnotetext{
${ }^{19}$ Estudo com abrangência latino-americana, em parceria com a Universidade de Navarra (Espanha), lançado pela Fundação Telefônica, em março de 2009, intitulado: "Geração Interativa na Ibero-América: crianças e adolescentes diante das telas”.
} 
e a escola não pode deixar de se integrar ou ver tais processos como nocivos à educação." Essa também é a idéia de C1: "Entendo que a mídia está totalmente presente na vida das crianças e não podemos deixar de aliá-la à educação até para garantir que ela seja positiva para os alunos".

Estas falas vão à mesma direção das anteriores, ou seja, os professores sabem que os alunos fazem parte de uma cultura perpassada pela questão midiática e que a escola deve estar integrada às práticas comunicacionais com mídias. Embora saibam, não utilizam estas mesmas mídias em suas aulas, conforme apontamos na análise de questões anteriores.

Sem dúvida, a escola pode ajudar seus alunos a se tornarem sujeitos reflexivos e responsáveis pela construção de seu próprio processo de conhecimento, o que inclui serem também atuantes no processo de recepção diante da programação da TV e das telas do computador. Certamente, não é passando todos ou muitos momentos escolares fazendo cópias ou somente lendo material impresso, que os alunos poderão aprender criticidade e a emitir opiniões com argumentos lógicos e ponderados. É preciso superar traumas e mitos - que consideram por vezes que as mídias só manipulam as pessoas - e aprender a trabalhar com as linguagens midiáticas, incorporando-as ao cotidiano escolar, resgatando-as e aproveitando as inúmeras possibilidades que oferecem a professores e alunos de estabelecer diálogos, de posicionar-se quanto às questões sociais, culturais, quanto às formas de convivência na sociedade.

A ideia que as mídias são recursos e ferramentas, que podem ampliar a motivação para as aulas, também aparece em algumas respostas dos professores. P3 nos diz: "Nos dias de hoje é imprescindível utilizar essas ferramentas como suporte ou extensão do tema que está sendo trabalhado em sala de aula."

Também o professor C7 usa este conceito: "São ferramentas para tornar a educação/o ensino mais significativo para os alunos." Citamos mais duas falas de professores: "Esses recursos devem servir para incentivar as crianças e melhorar a educação.” (M8) "Uma relação interessante, que desperta muito o interesse dos alunos, enriquecendo o conteúdo e a assimilação do mesmo.” (M3)

Percebe-se, nas falas dos professores, que há uma compreensão das mídias, TV e computador, como ferramentas/recursos, com condições para motivar os alunos e melhorar as aulas. Conforme já discutimos, ao analisar outras falas, é importante que consigamos ir além da compreensão de mídias como recursos. No entanto, esta é sem 
dúvida, uma primeira compreensão, de onde podemos partir para trabalhar na perspectiva aqui proposta, das mídias na dimensão de novas instâncias de socialização, de novas formas de linguagem, que estão nos trazendo formas diferentes de relacionamento social, novas formas de aprendizagem e, portanto, nos exigindo novas formas de pensarmos as questões do ensino, das mediações docentes. Pensarmos em novas formas quanto aos processos de ensino aprendizagem, pensarmos em novas formações docentes, que nos permitam ser professores que dialoguem com os ecossistemas comunicativos, articulando-os às dimensões de nosso trabalho pedagógico e à produção contemporânea, essencialmente simbólica.

Quanto à questão 13, ainda gostaria de trazer o aspecto da falta de material nas escolas. O professor L10 diz: "Acredito na relação de uma forma bastante interessante. Mas, infelizmente as escolas não estão equipadas com recursos tecnológicos suficientes e acessíveis para as aulas." No mesmo sentido, a fala do professor L1: “As escolas deveriam ser mais equipadas. Fica difícil contar com o que os alunos assistem ou usam. Muitos não se interessam por alguns programas, só pelo videogame”.

Para que se possa efetivar um trabalho nas escolas na interface entre mídias e educação, sem dúvida as escolas precisam estar equipadas. Não é possível esperar ações dos professores, se não temos as condições mínimas para que estas ações e trabalhos aconteçam. Faz parte da implantação de políticas públicas voltadas para as questões da educomunicação, equipar as escolas com materiais que permitam um trabalho mais inovador e criativo por parte dos docentes.

Um aspecto que já analisamos em questões anteriores, mas que merece destaque, é um aparente paradoxo entre as falas dos professores quanto à relação entre mídias e educação e como eles mesmos dizem que são suas ações, quanto ao uso dessas mídias, no cotidiano escolar. Vejamos as falas dos professores e quais materiais utilizam em suas aulas e com qual periodicidade.

Tabela 3. Relação Mídias e educação, periodicidade e utilização de materiais pelos professores

\begin{tabular}{|l|l|l|l|}
\hline Professores & $\begin{array}{l}\text { Fala dos professores quanto à relação entre } \\
\text { mídias e educação }\end{array}$ & $\begin{array}{l}\text { Materiais que } \\
\text { utilizam nas aulas }\end{array}$ & $\begin{array}{l}\text { Periodicidade de } \\
\text { uso dos materiais }\end{array}$ \\
\hline L7 & $\begin{array}{l}\text { Entendo que é uma relação interdependente, } \\
\text { pois o processo educativo acontece não só } \\
\text { dentro da escola, como também nas }\end{array}$ & Livro & Tunca \\
&
\end{tabular}




\begin{tabular}{|c|c|c|c|}
\hline & mídias. Será que faço isso? & Lousa & Todas as aulas \\
\hline ME 7 & $\begin{array}{l}\text { A TV, o computador mantém os conteúdos } \\
\text { atualizados. Nos dias de hoje é necessário } \\
\text { este auxílio para acompanhar o ritmo das } \\
\text { mudanças e as novas informações. }\end{array}$ & $\begin{array}{l}\text { Computador } \\
\text { Lousa }\end{array}$ & $\begin{array}{l}\text { Nunca } \\
\text { Toda aula }\end{array}$ \\
\hline $\mathrm{O} 4$ & $\begin{array}{l}\text { A TV e o computador são ferramentas } \\
\text { importantes com informações variadas que } \\
\text { acrescentam diariamente, e de maneira } \\
\text { rápida, uma diversidade de conteúdos que } \\
\text { podem ser trabalhados em sala de aula. }\end{array}$ & $\begin{array}{l}\text { Lousa } \\
\text { Livro } \\
\text { TV } \\
\text { Computador }\end{array}$ & $\begin{array}{l}\text { Toda aula } \\
\text { Toda aula } \\
\text { Nunca } \\
\text { Deixa em branco }\end{array}$ \\
\hline
\end{tabular}

Fonte: questionários respondidos pelos professores participantes da pesquisa

Esta incongruência entre as falas dos professores quanto à importância das mídias em sua relação com educação e a forma como utilizam estas mesmas mídias em suas aulas é um ponto de destaque para pensarmos em nossos cursos de formação de docentes. Será que não temos essa mesma incongruência em nossos cursos? Até mesmo em nossos documentos oficiais sobre formação de professores? Falamos, teoricamente, das propostas para educação, temos estudos e pesquisas avançados e, no cotidiano de nossas escolas, nos mantemos com as mesmas práticas e metodologias... Como avançar e conseguir, efetivamente, uma articulação entre teoria e prática, onde nossa construção de conhecimento na área pedagógica possa transformar nossos hábitos enquanto professores?

Esta pesquisa apresenta alguns fios desta rede que estamos tecendo juntos. Podemos entrelaçá-los, criar novas tramas, construir tecidos diferentes, com o jeito do coletivo, com as contribuições de outras áreas, tecer junto com os comunicadores, junto com os antropólogos. Tecer junto com as crianças e adolescentes, com sua forma - por vezes muito diferente da nossa - de estar no mundo, de comunicar-se, de nos dizer quais são seus anseios e sonhos, mesmo que às vezes de uma forma meio desconexa ou conectada de múltiplas maneiras, numa velocidade que nos espanta...

Podemos tecer juntos, enquanto professores-comunicadores.

Os dados apresentados neste capítulo trazem indicativos importantes - partindo de como os professores percebem sua prática docente - para os cursos de formação inicial. 
Professores formados há mais de dez anos, maioria mulheres, não tiveram disciplinas que tratassem de questões referentes à comunicação midiática. Em seu cotidiano, mesmo percebendo a importância da relação entre mídia e educação, estão muitas vezes em escolas sem equipamentos, com poucos momentos de formação contínua que abordem a produção midiática em nossas sociedades e como fazer a mediação dessa produção nas aulas. Não se sentem preparados para o trabalho que é exigido deles. Diante deste cenário é que propomos a premência de repensarmos nossos cursos de Pedagogia, onde formamos nossos professores para os anos iniciais de escolarização de nossas crianças. Enfatizamos também a importância de que essas preocupações se façam presentes nas políticas e ações de formação continuada de professores, que embora não seja o foco das análises aqui desenvolvidas, tem papel essencial para se assegurar a qualidade da escolarização das crianças e jovens em nosso país.

$\mathrm{Na}$ parte final desta tese, apresento algumas considerações com o propósito de contribuir com o esforço de formação de mediadores que atuarão nos novos cenários que se constroem todos os dias nas sociedades midiáticas contemporâneas. 


\section{CONSIDERAÇÕES FINAIS:}

Nessa última década do século XX são ainda insuficientes os
conhecimentos prático-teóricos de que dispomos sobre
comunicação e meios de comunicação, com vistas ao objetivo
de uma educação escolar que participe da formação de
cidadãos. Ações e reflexões que contribuam para a produção
desses conhecimentos são necessárias e urgentes, por parte de
professores e pesquisadores, tendo em vista as mudanças que
queremos fazer nas relações comunicacionais das quais somos
resultado e as quais, simultaneamente, produzimos na escola
inserida no mundo da contemporaneidade. (REZENDE E
FUSARI)

Neste trabalho apresentei algumas reflexões sobre a sociedade midiática na qual estamos inseridos, com relações comunicacionais perpassadas por transformações tecnológicas e culturais, que nos apresentam novas demandas em diversas áreas das relações humanas, inclusive quanto às formas de pensarmos os processos educacionais e escolares. Como nos aponta REZENDE E FUSARI (1992), se queremos uma educação escolar que colabore efetivamente na formação de cidadãos, não podemos nos furtar a pensar essa cidadania nas sociedades contemporâneas, com seus cotidianos perpassados por diversas mídias, com as quais todos nós interagimos em nossas ações diárias, nas diversas relações que estabelecemos. Como uma das instituições centrais na sociedade, quanto à produção de cultura e conhecimento e construção de formas de socialização, a escola também vive momentos atravessados pelas transformações tecnológicas e comunicacionais midiáticas, que interpelam os professores em suas atividades docentes.

As transformações tecnológicas e culturais vivenciadas trouxeram novas formas de relações entre as pessoas, novas formas de apreender e aprender o real, impactando a todos nós, mas de forma especial, impactando as novas gerações. Nascidas e criadas em sociedades videotecnológicas (PRENSKY, 2006; CITELLI, 2011; OROZCO, 2009), temos hoje a chamada geração de nativos digitais (PRENSKY, 2006), que aprende de novas maneiras, com raciocínios e sinapses mais rápidas, sem a linearização de pensamento com a qual tradicionalmente lidavam nossos processos de ensino aprendizagem. As novas tecnologias e suas diferentes e convergentes linguagens também propiciaram cenários de experimentação, com novas lógicas de produção, exigindo uma educação que possa dialogar com essas novas demandas culturais, numa polissemia contemporânea das sociedades midiáticas. 
Diante deste quadro, temos colocado o desafio de outras formas de educação, que não abandone as funções usuais das escolas e de seus professores, quanto aos processos de socialização e construção do conhecimento, junto às novas gerações, mas que também perceba a necessidade da construção de um diálogo e de aproximações com outras instâncias socializadoras e produtoras de cultura nas sociedades atuais, tais como as mídias comunicacionais eletrônicas e digitais, constituidoras dos processos de comunicação e construtoras de sentidos diante da vida e das relações humanas.

Ao assumirmos a tecnicidade midiática como dimensão estratégica da cultura (MARTÍN-BARBERO e REY, 2004), pensamos uma escola que necessita assumir-se como produtora de cultura, como produtora social de comunicação, com professores que sejam mediadores dos processos comunicacionais em suas interfaces com as questões educacionais e escolares.

Este cenário atual, com novas demandas e com novas interfaces entre as áreas de educação e comunicação, traz uma necessidade de repensar os processos de formação inicial de docentes, que são lócus de preparação dos professores para seu trabalho nas escolas. Conforme apontado por GATTI e BARRETO (2009) ainda temos, de forma geral, no Brasil, cursos de formação pautados em uma formação teórica desvinculada das questões cotidianas e concretas das escolas. BELLONI (2009) também nos aponta a necessidade de políticas públicas que pensem as relações entre mídias e educação, articulando a formação de professores às demandas sociais e culturais atuais.

Os estudos que realizamos nos cursos de formação inicial de professores na cidade de Santos, quanto aos processos formativos nas disciplinas estudadas pelos futuros professores, na interface entre educação e comunicação midiática, trazem a fragilidade do preparo dos mesmos. Nos quadros curriculares dos cursos constam poucas disciplinas que discutam temas relativos à educomunicação, oferecendo praticamente nenhum espaço para reflexões necessárias diante das transformações tecnológicas e culturais pelas quais vem passando nossas sociedades, exigindo habilidades e conhecimentos diferentes dos professores. Estas lacunas nos cursos de formação inicial nos levaram a refletir e a debruçar o olhar sobre as práticas pedagógicas dos docentes, trabalhando questões com 113 professores da rede municipal de Santos, para saber como eles percebiam seu trabalho com mídias e como entendiam a relação entre comunicação e educação. A análise dos questionários trabalhados com os professores evidencia um interessante paradoxo. Mesmo apontando que é necessário e 
fundamental trabalhar com as novas tecnologias, tais como TV e computador, e suas linguagens nas aulas, em função delas já serem utilizadas pelos alunos e servirem como forma de motivação e atualização, os professores trazem dados que mostram uma atividade docente pautada, cotidianamente, na utilização da lousa e de livros, com pouca diversificação de metodologia e de trabalho com diferentes linguagens. Os professores ainda apontam que se sentem despreparados para o trabalho com novas mídias, destacando a necessidade de momentos de formação que possam ajudá-los em suas tarefas nas escolas.

Para que os professores, além de darem conta das questões de ensino tradicionalmente estabelecidas para o âmbito da escola e das práticas docentes, efetivamente possam ser mediadores diante da produção simbólica midiática das sociedades atuais, é preciso que sejam preparados para isso, vivenciando em seus processos formativos, experiências e construção de conhecimentos que colaborem no exercício destas mediações. Neste sentido, os cursos de formação inicial de docentes, ao lado dos processos de formação usuais, devem ocupar-se da estruturação de currículos que promovam uma dialogicidade entre as questões pedagógicas e didáticas e os apelos e desafios apresentados pelos ecossistemas comunicativos das sociedades contemporâneas. A dimensão cultural que se apresenta hoje, perpassada pelas mídias e suas diferentes linguagens e possibilidades, é fundamental como um dos eixos a estruturar os processos de formação inicial de professores. Para além da formação que temos hoje, mais pautada em códigos verbais, os futuros professores precisam de espaços e tempos em seus cursos que colaborem para a reflexão, elaboração e apropriação de novos códigos e linguagens. Não há possibilidade de transformação no trabalho docente nas escolas, se os processos de formação inicial não estiverem articulados com as problemáticas atuais das escolas e dos alunos. Logicamente, não se desconsideram aqui todos os outros aspectos necessários a uma educação escolar compromissada com a igualdade social e a excelência, tais como condições estruturais das escolas, remuneração dos professores, políticas públicas bem definidas, mas se enfatiza a necessidade urgente da escola assumir seu papel enquanto construtora de cultura e produtora social de comunicação, numa sociedade midiática como é a nossa, perpassada por novas formas de construção de conhecimento.

Num mundo midiático como o nosso, com uma presença constante e a cada dia maior, de novas tecnologias de comunicação e informação, não há como entender a 
cidadania fora das nossas interações com essas tecnologias e suas linguagens. Todas essas tecnologias têm, em suas produções culturais, intencionalidades, que alguns estudiosos vêm chamando de pedagogias culturais (COSTA, 2009; MOMO, 2007). Ao assumirmos que estas pedagogias culturais nos interpelam, nos constituem enquanto sujeitos, nos apresentam formas de ver e entender o mundo em que vivemos e as relações que estabelecemos, torna-se urgente uma escola e professores que dialoguem com formas de currículo apresentadas por estes artefatos culturais, sendo mediadores diante das produções culturais simbólicas da nossa sociedade, contribuindo para que os alunos também possam ser mediadores e produtores de cultura, participantes ativos e críticos, capazes de buscar caminhos alternativos na construção de uma sociedade mais democrática e igualitária, com qualidade de vida para todos.

O cenário atual da sociedade e das transformações velozes a que assistimos, nos pede um misto de criatividade e ousadia. Podemos usar as novas linguagens, com todas as possibilidades que nos trazem, percebendo a complexidade do mundo em que vivemos, constituído em redes, com inúmeros saberes e fazeres, com os quais podemos criar e recriar nossos tempos e espaços, nossas relações sociais. Formarmos professores mediadores e produtores sociais de comunicação, que busquem alternativas e possam criar, vislumbrando o novo, na construção de mudanças e de alternativas para nosso mundo. Podemos pensar novas formas de educação, assumindo a pluralidade e a diversidade de sentidos, de linguagens, que nos possibilitem trabalhar nos contextos das sociedades midiáticas atuais, em que somos construídos todos os dias como cidadãos, como educadores, como seres humanos.

Neste sentido, os cursos de formação inicial de professores precisam estar pautados em fundamentos que evidenciem a importância de desenvolver a autonomia e a consciência crítica dos docentes, inclusive quanto às mudanças que estão ocorrendo nas sociedades, em função das transformações tecnológicas comunicacionais, que trazem impactos e demandas para os processos educacionais e escolares. Ao assumirmos que os professores tem como lócus inicial de sua formação e da construção da sua profissionalidade docentes, os cursos de Pedagogia, torna-se evidente que as experiências, saberes e fazeres trabalhados nesses cursos comporão uma estruturação do ser docente dos futuros professores. Se os fundamentos dos cursos de formação permanecerem pautados em códigos verbais, centrados em exposição de conteúdos, com processos de comunicação verticalizados, onde pouco se trabalha na perspectiva 
dialógica da construção dos conhecimentos, onde pouco se ajuda a perceber que as relações estão pautadas na interação com os outros - relações de alteridade perpassadas por sentidos e significados construídos também pelas mídias e suas inúmeras linguagens, não conseguiremos efetivamente avançar nas propostas para uma formação inicial de professores que responda as demandas das sociedades contemporâneas e dos alunos que chegam as nossas escolas nestes tempos.

Este trabalho, assumindo seus limites e possibilidades, assumindo que o diálogo entre comunicação e educação é um trabalho necessário, mas com um longo caminho a ser ainda percorrido, busca indicar alguns pontos para reflexão, que permitam a construção de novas perspectivas para os processos de formação inicial de professores.

Um ponto a ser destacado é pensar os cursos de formação docentes assumindo a dimensão estratégica que os processos comunicacionais midiáticos têm nas sociedades contemporâneas. Conforme destacamos ao longo desta pesquisa, vivemos em sociedades atravessadas pela presença das mais diversas mídias, com linguagens específicas e que trazem novas formas de produção cultural bem como outros processos de socialização. Nossos cotidianos são perpassados por inúmeras telas, que nos trazem informações, nos apresentam sentidos e significados diante do mundo em que vivemos. Conformam nossa identidade, nossas formas de nos relacionarmos uns com os outros, as formas de compreendermos as relações humanas e sociais. Os significados apresentados nas diversas mídias, em especial na TV e na Internet, apresentados as nossas sociedades cotidianamente, ao longo de todos os dias, colaboram para que tomemos posicionamentos, diante de questões essenciais a vida das sociedades. Ao pensarmos que são grandes conglomerados econômico-financeiros que controlam a produção e circulação de informações nas mídias, torna-se evidente a questão estratégica. Os cursos de formação de professores precisam colocar nas pautas de seus cursos e disciplinas a discussão sobre a produção de comunicação social. Não se trata somente de preparar os professores para uma utilização da tecnologia e das linguagens. Esta seria uma perspectiva muito instrumental, técnica, que poderia nos levar a contribuir para uma ainda maior concentração de poder nas mãos dos donos dos grandes conglomerados comunicacionais. Os futuros professores precisam compreender a dinâmica dos processos de produção e circulação das informações, a dinâmica da produção de sentidos e significados via diferentes mídias e suas linguagens, que impactam o cotidiano das pessoas, suas formas de ver e estar no mundo. 
Mas, como poderão os professores estar preparados para essa análise das sociedades midiáticas contemporâneas, se essa for uma discussão ausente dos seus processos de formação? Portanto, esse é um fundamento a ser destacado nos cursos de Pedagogia, um dos eixos do curso: compreender a dimensão estratégica da comunicação midiática e de suas produções simbólicas.

Outro ponto a ser destacado é a importância do desenvolvimento da capacidade crítica de análise e leitura de diferentes repertórios e linguagens, nos mais variados suportes. Essa capacidade de análise crítica também precisa ser desenvolvida. Como aprendemos a ler uma matéria de jornal e interpretá-la? Se manuseamos o jornal, nos familiarizamos com seu formato e vivenciamos processos de mediação, onde uma outra pessoa nos ajuda a ver além do que já estamos vendo. Nos ajuda a entender a construção da mensagem, a forma de utilização da linguagem. Como já nos apontava Vygotsky (1984), há uma construção social da mente, onde, por meio de processos de mediação e interação, vamos construindo nossos pensamento e nossas formas de linguagem, ou seja, nossa forma de interpretar o mundo. Os cursos de formação inicial de professores, em suas atividades e fazeres cotidianos, podem estar focados em desenvolver a capacidade crítica dos alunos em relação a todas as formas possíveis de comunicação e construção de significados existentes atualmente. Em diversos momentos, em minha trajetória como formadora de professores, percebi a distância entre os alunos - futuros docentes - e a produção cultural que circula em nossas sociedades, inclusive aquela a que tem acesso nossas crianças e adolescentes. Destaco aqui, entre outros exemplos possíveis, os games. São uma produção cultural contemporânea, de fácil acesso às crianças, e oferecem possibilidades de leitura de mundo. Apresentam formas de conduta: em inúmeros desses jogos, para ganhar pontos e mudar de fase, o jogador deve bater nos personagens adversários, deve roubar, deve desrespeitar as outras pessoas. Como podemos desenvolver criticidade diante dessa mídia? Para qualquer processo de mediação, é necessário que eu conheça o que vou mediar, para que possa me posicionar, pensar sobre, ter uma opinião formada. Portanto, se nossas crianças jogam games, é preciso que nós, professores mediadores, conheçamos os games, para que possamos ajudá-las a desenvolver criticidade diante do artefato cultural com o qual estão interagindo. Em qual tempo e espaço podem os futuros professores ter contato mediado com games, programas de TV, sites, redes sociais? Em cursos de formação inicial de professores. Portanto, um segundo ponto que destaco é a necessidade de incorporar em 
nossos cursos tempos e espaços que permitam a análise e reflexão sobre os produtos culturais da atualidade, em especial aqueles com os quais nossos alunos, que freqüientam nossas escolas, tem contato diariamente, colaborando na construção de seus processos identitários e de formas de ler o mundo em que vivem. Cursos que possam contribuir enquanto espaço de significação para as práticas docentes. (Franco, 2010)

Além de desenvolver a capacidade crítica, é necessário que a escola e os professores também se assumam como produtores culturais. Sem dúvida, a postura de, diante de uma produção, ser capaz de interpretá-la, é essencial, mas já não é suficiente. Falamos hoje de novos lugares do saber, de descentralização dos processos escolares em relação à produção e circulação de informações e saberes. Há uma diversidade de linguagens e suportes, que permitam experimentações e novas construções culturais. Há toda uma produção simbólica de cultura nas sociedades contemporâneas, que precisamos trazer definitivamente para um diálogo com os processos educacionais e escolares. Relembrando nossa pesquisa com os professores nas escolas municipais: a maioria deles afirma perceber a importância das mídias, que TV e computador colaboram na motivação e aprendizagem dos alunos, que colaboram para trazer o mundo para a sala de aula. Embora percebam a importância, ela não se traduz em ações: ou seja, os professores não dialogam, em suas práticas docentes, com os meios de comunicação. Não estamos nos assumindo, enquanto professores, como construtores de cultura e é isto que somos! Trabalhamos com saberes construídos historicamente, com experiências da humanidade, mediamos esses saberes. Se esses saberes são hoje atravessados pelas questões midiáticas, se as linguagens das mídias são também saberes, temos que trabalhar nessa dimensão. Cursos de formação inicial de professores que assumam a produção social da comunicação, com vistas à qualidade de vida para todos, em sociedades inclusivas.

Ao destacarmos a centralidade dos processos comunicativos em nossas sociedades, vimos, ao longo deste trabalho, trabalhando com o conceito de educomunicação, das interfaces possíveis entre processos comunicacionais e processos educacionais e escolares. Como nos coloca Machado (2009), não queremos evidenciar uma discussão na interface comunicação/educação que nos conduza a uma visão técnica, instrumental dos meios e processos de comunicação. Assumimos a educomunicação como um espaço para o diálogo, para a construção de relações de alteridade. 
As práticas educomunicativas são espaços do estar junto, espaços de efetivação do diálogo de maneira criativa. Se isto é utópico, então assim somos. A capacidade criadora e criativa do ser humano é o que nós, educomunicadores, temos que primeiramente reconhecer em nós mesmos e assim cultivar. (MACHADO, 2009: 68)

Essa perspectiva da educomunicação enquanto espaço para o diálogo é a que trazemos para a interface dos cursos de formação inicial de professores. Que os nossos cursos estejam pensados e estruturados enquanto espaços para o diálogo, que é hoje um diálogo perpassado também pelas inúmeras mídias e suas linguagens. Que possamos usar todas as potencialidades dessas mídias em nossas atividades docentes, reinterpretando-as e ressignificando-as em função de nossos objetivos enquanto formadores de futuros formadores, não esquecendo da imensa capacidade criadora do ser humano. Ao trabalharmos com a subjetividade de nossos alunos, com as possibilidades de experimentação e criação- também proporcionadas pelas mídias -, ampliamos as perspectivas atuais, permanecendo abertos a novos caminhos $\mathrm{e}$ alternativas.

Ainda é importante trazer para reflexão as discussões sobre políticas docentes no Brasil (GATTI, BARRETTO e ANDRÉ, 2001), que apontam o desencontro entre o que dizem as políticas educacionais e, em especial, as políticas de formação de professores e aquilo que efetivamente acontece nos currículos dos cursos, nas práticas das escolas. Como apontamos em nossa pesquisa, ao analisarmos as matrizes curriculares dos cursos de Pedagogia da cidade de Santos, há uma fragilidade no preparo dos professores para o seu trabalho em sociedades comunicacionais midiáticas. Embora os documentos oficiais sobre formação de professores insistam no sentido de incorporar aos cursos o domínio das tecnologias e suas linguagens, enfatizando aspectos da comunicação contemporânea nos eixos dos cursos de Pedagogia, essa dimensão fica praticamente ausente dos quadros curriculares. Conforme pesquisa realizada por GATTI e BARRETTO (2009) e LIBÂNEO (2010), há um desequíbrio entre teoria e prática nos currículos e nas ementas das disciplinas, onde se trata genericamente sobre educação e seus fundamentos, sendo a escola, enquanto instituição social de ensino, um elemento quase ausente nas propostas das ementas. Estamos formando professores de formas abstratas, que não trazem para os processos formativos, para a discussão, as situações concretas que serão vivenciadas pelos professores nas escolas. Portanto, há um repensar dos cursos de formação inicial de professores que está na interface entre as propostas das instituições 
formadoras e as políticas docentes do país, sendo necessário ainda trazer para esse repensar as secretarias de educação, que no cotidiano, estão normatizando e orientando as atividades docentes nas escolas. Há um diálogo a ser construído também nesta dimensão, entre educadores, sejam eles os que estão no dia a dia das escolas, os que estão pensando e elaborando as normas e legislações, sejam eles os que estão nas universidades, pensando e vivenciando a formação dos formadores. A formação continuada precisa se ocupar, no caso dos professores já formados e em exercício, com os aspectos que não foram trabalhados ao longo da formação inicial, bem como com as novas questões e desafios que cotidianamente se colocam nas salas de aula.

Ao assumirmos o ensino enquanto uma prática social complexa, assumimos também que a construção dos processos de diálogo será igualmente complexa, abarcando múltiplos fatores, que exigem nossa reflexão acurada, nossa percepção diante das sociedades atuais, com clareza de onde queremos chegar, qual projeto de sociedade temos em mente.

Repensar os fundamentos dos cursos de formação inicial de professores é uma tarefa urgente. Como coloca Almeida (2011), precisamos de uma formação densa para fundamentar uma prática que é complexa. Ao apresentar como preocupação deste trabalho a dinâmica dos processos de formação docente em sociedades midiáticas, onde os alunos aprendem de formas diferenciadas, apontando novas demandas para os professores e consequentemente, para seus processos de formação, trazemos uma problemática densa, perpassada por inúmeros aspectos, que estão articulados entre si. Não pretendemos dar conta de todos os aspectos, nem propor soluções definitivas. Tivemos somente a pretensão de trazer para a discussão elementos que nos ajudem a pensar novas possibilidades para os cursos de formação docente, que tragam uma perspectiva de diálogo entre as áreas de comunicação e educação, onde podemos juntar saberes e fazeres, construindo novas redes de significados, novos sentidos para as nossas vidas cotidianas, que não esqueçam da dimensão da beleza dos diálogos, dos encontros entre seres humanos. Que não esqueçam que a plenitude da vida é para todos, que nossos conhecimentos devem produzir sociedades melhores, com pessoas mais felizes e realizadas. Que nossas escolas sejam lugares onde a criação de novos caminhos seja constante, permitindo experimentações, ousadia, alegria, sonhos e utopias diversas, num encontro de todos, na força e na beleza do coletivo! 


\section{REFERÊNCIAS BIBLIOGRÁFICAS:}

AGUIAR, Márcia Ângela da Silva. A reforma da educação básica e as condições materiais das escolas. Em: SILVA, Ainda Maria Monteiro e AGUIAR, Márcia Ângela da Silva. (orgs.) Retrato da escola no Brasil. Brasília: s.d., 2004.

ALMEIDA, Maria Isabel. O trabalho dos educadores. Em: SILVA, Aída Maria Monteiro e AGUIAR, Márcia Ângela da Silva. (orgs.) Retrato da escola no Brasil. Brasília: s.d., 2004.

ALMEIDA, Maria Isabel. Pedagogia universitária e projetos institucionais de formação e profissionalização de professores universitários. Tese de LivreDocência. Departamento de Metodologia do Ensino e Educação Comparada. Faculdade de Educação. São Paulo: USP, 2011.

ALVES, Nilda (org.). Criar currículo no cotidiano. São Paulo: Cortez, 2004. Serie Cultura, memória e currículo, v.1.

ANDRÉ, M. E. D. O projeto pedagógico como suporte para novas formas de avaliação. IN. Amélia Domingues de Castro e Anna Maria Pessoa de Carvalho (Orgs.). Ensinar a Ensinar. São Paulo, 2001.

ANDRÉ, Marli e LUDKE, Menga. Pesquisa em educação: abordagens qualitativas. São Paulo: EPU, 1986.

ANDRÉ, Marli. A produção acadêmica sobre formação docente: um estudo comparativo das dissertações e teses dos anos 1990 e 2000. Revista Brasileira de Pesquisa sobre Formação de Professores. Autêntica, v.1, n.1, p.41-56, ago./dez. 2009.

ARDOINO, J. A formação do educador e a perspectiva multirreferencial. Minicurso ministrado na Universidade Federal de São Carlos, Departamento de Educação, Programa de Pós-Graduação em Educação, de 15 a 16 de Outubro, 1998. (Mimeo). 
ARDOINO, Jacques. Abordagem multirreferencial (plural) das situações educativas e formativas. Em: BARBOSA, Joaquim Gonçalves (coord.). Multirreferencialidade nas ciências e na educação. São Carlos: EdUFSCar, 1998.

AUGE, Marc. Apud MARTÍN-BARBERO, Jesús e GREY, Germán. Os exercícios do ver: hegemonia audiovisual e ficção televisiva. São Paulo: Editora SENAC, 2004.

BARBER, Benjamin R. Consumido: como o mercado corrompe crianças, infantiliza adultos e engole cidadãos. Rio de Janeiro: Record, 2009.

BARBOSA da Silva, Márcia. Criança e televisão: que contribuições ao trabalho docente na pré-escola? São Paulo, 1997. Tese (mestrado em educação). Faculdade de Educação, Universidade de São Paulo - USP.

BATISTA, Anália Soria e CODO, Wanderley. Crise de identidade e sofrimento. Em: CODO, Wanderley (coord.). Educação: carinho e trabalho. Petrópolis, RJ: Vozes, Brasília: Confederação Nacional dos trabalhadores em educação: Universidade de Brasília. Laboratório de Psicologia do trabalho, 2006.

BATISTA, Simone Rodrigues. Televisão e formação de professores: construindo mediações docentes. São Paulo: LCTE Editora, 2005.

BAUMAN, Zygmunt. Vida líquida. Rio de Janeiro: Jorge Zahar editora, 2007.

BELLONI, Maria Luiza. O que é mídia-educação. $3^{\text {a }}$. ed. rev. Campinas, SP: Autores associados, 2009. (Coleção Polêmicas do Nosso tempo; 78)

BERTI, Orlando Mauricio de Carvalho. YouTube e o fim da televisão no Brasil. Comunicação Científica apresentada no Grupo Temático de Produção e Recepção do XIV CELACOM - Colóquio Internacional da Escola Latino-Americana de Comunicação. Memorial da América Latina, São Paulo (SP), Brasil. 2010. 
BOFF, Leonardo. A águia e a galinha: uma metáfora da condição humana. Petrópolis, RJ: Vozes, 1997.

BOGDAN, R. e BIKLEN, S.K. Qualitative research for education. Boston, Allyn and bacon, 1982.

BRASIL. Lei no. 10172, de 9 de janeiro de 2001. Aprova o Plano Nacional de Educação e da outras providencias. Leis ordinárias. Brasília: Casa Civil da Presidência da Republica Federativa do Brasil/ Subsecretaria para Assuntos Jurídicos, 2001.

BRASIL. Conselho Nacional de educação. Parecer CNE no. 009/2001. Diretrizes Curriculares Nacionais para a formação de professores da educação básica, em nível superior, curso de licenciatura de graduação plena.

BRASIL. Lei no. 9394, de 20 de Dezembro de 1996. Estabelece as diretrizes e bases da educação nacional. Leis Ordinárias. Brasília: Casa Civil da Presidência da Republica Federativa do Brasil/ Subsecretaria para Assuntos Jurídicos, 1996.

BRASIL. Ministério da educação. Conselho Nacional de Educação. Resolução CNE/CP no. 01, de 15 de Maio de 2006. Institui diretrizes Curriculares Nacionais Para o Curso de Graduação em Pedagogia, licenciatura. Brasília: MEC/CNE, 2006.

BRASIL. Ministério da Educação. Fundo Nacional de Desenvolvimento para a Educação. Plano de Metas Compromisso Todos pela Educação. Brasília, junho de 2007.

BRASIL. Secretaria de Educação fundamental. Parâmetros Curriculares Nacionais. Brasília: MEC/SEF, 1997.

BUCKINGHAM, David. Crescer na era das mídias eletrônicas. São Paulo: Edições Loyola, 2007. 
BUMHAM, Teresinha Fróes. Complexidade, multirreferencialidade, subjetividade: três referencias polêmicas para a compreensão do currículo escolar. Em: Revista Em Aberto. Brasília, ano 12, no. 58, abr/jun 1993.

CANCLINI, Nestor Garcia. Consumidores e cidadãos, conflitos multiculturais da globalização. Rio de Janeiro: UERJ, 1995.

CHAMON, Magda. Trajetória de feminização do Magistério e a (con)formação das identidades profissionais. Em: VI Seminário da Redestrado - Regulação Educacional e Trabalho docente. UERJ- Rio de Janeiro, 2006.

CITELLI, Adilson (org.). Aprender e ensinar com textos não-escolares. São Paulo: Cortez, 1997.

CITELLI, Adilson. Comunicação e educação. A linguagem em movimento. São Paulo: Editora SENAC, 2004.

CITELLI, Adilson. Linguagens da comunicação e desafios educacionais: o problema da formação dos jovens docentes. Em: Comunicação e Educação, São Paulo: CCA-ECAUSP/Paulinas, n.1. jan/abr 2010.

CITELLI, Adilson. Comunicação e Educação: implicações contemporâneas. Em: CITELLI, Adilson e COSTA, Maria Cristina. (orgs.) Educomunicação: construindo uma nova área de conhecimento. São Paulo: Paulinas, 2011. (Coleção Educomunicação)

CODO, Wanderley (coord.). Educação: carinho e trabalho. Petrópolis, RJ: Vozes, Brasília: Confederação Nacional dos trabalhadores em educação: Universidade de Brasília. Laboratório de Psicologia do trabalho, 2006.

CODO, Wanderley e VASQUES-MENEZES, Ione. O que é burnout? Em: CODO, Wanderley (coord.). Educação: carinho e trabalho. Petrópolis, RJ: Vozes, Brasília: 
Confederação Nacional dos trabalhadores em educação: Universidade de Brasília. Laboratório de Psicologia do trabalho, 2006.

CONTRERAS, José. A autonomia dos professores. São Paulo: Cortez, 2002.

COSTA, Marisa Vorraber. A escola mantem-se como uma instituição central na vida das sociedades e das pessoas. Em: COSTA, Marisa Vorraber (org.) A educação na cultura da mídia e do consumo. Rio de janeiro: Lamparina, 2009.

COSTA, Marisa Vorraber. Quem são, que querem, que fazer com eles? Eis que chegam às nossas escolas as crianças e jovens do século XXI. Em: Moreira, Antonio Flavio; GARCIA, Regina Leite; ALVES, Maria Palmira (orgs.). Currículo: pensar, sentir e diferir. (v.II). Rio de Janeiro: DP\&A, 2005.

CURY, Carlos Roberto Jamil. Notas acerca do saber e do saber fazer da escola. Cadernos de Pesquisa. São Paulo, 40: 58-60, fev 1982.

DEBORD, Guy. A sociedade do espetáculo. Paris: Champ Libre, 1967.

DEMO, Pedro. Pesquisa: princípio científico e princípio educativo. São Paulo: Cortez, 1990.

DINIZ, Julio Emilio. Formação de professores - pesquisa, representações e poder. Belo Horizonte: Autêntica, 2006.

DOMINGUES, Isaneide. O coordenador pedagógico e o desafio da formação contínua do docente na escola. 2009. Tese (doutorado). Faculdade de Educação da Universidade de São Paulo, São Paulo.

ESTEVE, José M. Mudanças sociais e mudanças na educação: da educação de elite à educação de massas. Em: NÓVOA, Antonio. Profissão Professor. Porto, Portugal: Porto Editora, 1995. (Colecção Ciências da Educação) 
FAURE, E. Aprender a ser. Madrid: Alianza, 1973.

FISCHER, Rosa Maria Bueno. Televisão e educação: fruir e pensar a TV. $3^{\text {a }}$. ed. Belo Horizonte: Autêntica, 2006.

FISHER, Rosa Maria Bueno. Identidade, cultura e mídia: a complexidade de novas questões educacionais na contemporaneidade. Em: SILVA, L.H. (org.) Século XXI. Qual conhecimento? Qual currículo? Petrópolis: Vozes, 2001.

FISHER, Rosa Maria Bueno. O mito na sala de jantar: leitura interpretativa do discurso infanto-juvenil sobre televisão. Rio de Janeiro, 1982. Tese (Mestrado em educação) - Instituto de estudos avançados em educação - Fundação Getulio Vargas.

FRANCO, Maria Amélia Santoro. A metodologia de pesquisa educacional como construtora da práxis investigativa. Em: Nuances, estudos sobre educação. Ano 9, v.9, nos. 9 e 10, jan/jun/jul/dez, São Paulo: UNESP - Presidente Prudente, 2003.

FRANCO, Maria Amélia. Saberes pedagógicos e prática docente. Livro de anais do XIII ENDIPE: Educação formal e não formal, processos formativos e saberes pedagógicos. Vol.1, p.27-50. Recife: Edições Bargaço, 2006.

FRANCO, Maria Amélia. Entre a lógica da formação e a lógica das práticas; a mediação dos saberes pedagógicos. Em: Revista Educação e Pesquisa, São Paulo, v.34, n.1, p. 109-126, jan./abr. 2008.

FRANCO, Maria Amélia. Didática e Pedagogia: da teoria de ensino à teoria da formação. Em: FRANCO, Maria Amélia e PIMENTA, Selma Garrido. Didática: embates contemporâneos. São Paulo: Edições Loyola, 2010.

FREIRE, Paulo. Educação como prática da liberdade. Rio de Janeiro: Paz e Terra, 1971. 
FREIRE, Paulo. Pedagogia da esperança: um reencontro com a pedagogia do oprimido. Rio de Janeiro. Paz e Terra, 1994.

GATTI, Bernardete Angelina e BARRETO, Elba Siqueira de Sá. Professores do Brasil: impasses e desafios. Brasília: UNESCO, 2009.

GATTI, Bernadete Angelina, BARRETO, Elba Siqueira de Sá e ANDRÉ, Marli. Políticas docentes no Brasil: um estado da arte. Brasília: UNESCO, 2011.

GHEDIN, Evandro; LEITE, Yoshie e ALMEIDA, Maria Isabel. Formação de professores: caminhos e descaminhos da prática. Brasília: Liber Livro Editora, 2008.

GONÇALVES, Marluce Torquato Lima e NUNES, João Batista Carvalho. Tecnologias de informação e comunicação: limites na formação e prática dos professores. Anais da 29. Reunião Anual da ANPED - Caxambu, Minas Gerais, 2006.

GUIMARÃES, Valter Soares. Formação de professores: saberes, identidade e profissão. Campinas, SP: Papirus, 2004. (Coleção Entre Nós Professores)

IGNACIO, Patrícia. Crianças, consumo e identidade. Em Costa, Marisa Vorraber. (org.) A educação na cultura da mídia e do consumo. Rio de Janeiro: Lamparina, 2009.

IMBERNÓN, F. La profesión docente desde El punto de vista internacional: que dicen los informes? Revista de Educación, n.340, p. 41-49, 2006.

JULIA, D. A cultura escolar como objeto histórico. Revista Brasileira de História da Educação, Campinas, v.1, n.1, 2001.

LIBÂNEO, José Carlos. Adeus professor, adeus professora: novas exigências educacionais e profissão docente. São Paulo: Cortez, 1998. (Coleção Questões da Nossa época; v. 67) 
LIBÂNEO, José Carlos. Democratização da escola pública: a pedagogia crítico-social dos conteúdos. São Paulo: Loyola, 1984.

LIBÂNEO, José Carlos. Didática. São Paulo: Cortez, 1991.

LIBÂNEO, José Carlos. Prefacio. Em: GUIMARÃES, Valter Soares. Formação de professores: saberes, identidade e profissão. Campinas, SP: Papirus, 2004. (Coleção Entre Nós Professores)

LIBÂNEO. José Carlos. A escola brasileira em face de um dualismo perverso: escola do conhecimento para os ricos, escola do acolhimento social para os pobres. X Encontro de Pesquisa em Educação da Anped- Centro Oeste, julho 2010.

LISITA, Verbena. Didática e formação de professores: um estudo sobre a possibilidade da reflexão crítica. Tese de doutoramento. São Paulo, USP, 2006.

LOPES, Maria Imacollata. Pesquisa em comunicação. São Paulo: Loyola, 2001.

MACHADO, Eliany Salvatierra. Pelos caminhos de Alice: vivências na educomunicação e a dialogicidade do Educom.TV. 2009. Tese (Doutorado em Ciência da comunicação). Escola de Comunicações e artes, Universidade de São Paulo, São Paulo.

MAGALHÃES, Claudio Marcio. Os programas infantis da TV: teoria e prática para entender a televisão feita para crianças. Belo Horizonte: Autêntica, 2007. (Cultura, mídia e escola, 1)

MARTÍN-BARBERO, Jesús. Desafios culturais da comunicação à educação. Comunicação e Educação. São Paulo, no. 18, maio/agosto, 2000.

MARTÍN-BARBERO, Jesús. Heredando El futuro: pensar La educacion desde La comunicacion. Em Nomadas. Bogotá. Fundacion Universidad Central, 1996, p. 19. 
MARTÍN-BARBERO, Jesús. America Latina e os anos recentes: o estudo da recepção em comunicação social. Em SOUSA, Mauro Wilton de (org.) Sujeito, o lado oculto do receptor. São Paulo: Brasiliense, 1995: 39-68.

MARTÍN- BARBERO, Jesús e REY, Germán. Os exercícios do ver: hegemonia audiovisual e ficção televisiva. São Paulo: Editora SENAC, 2004.

MARTÍN-BARBERO, Jesús. Uma aventura epistemológica. Em Matrizes. São Paulo, ano 2, no. 02, p. 143-162, 2009.

MARTINS, João Batista. Contribuições epistemológicas da abordagem multirreferencial para a compreensão dos fenômenos educacionais. Em: Revista Brasileira de Educação. São Paulo, maio/jun/jul/ago 2004, no. 26.

MOMO, Mariângela. Mídia e consumo na produção de uma infância pós-moderna que vai à escola. 2007. Tese (Doutorado em Educação) - Programa de Pós-Graduação em Educação, Universidade Federal do Rio Grande do Sul, Porto Alegre.

MORAN, José Manuel. Interferências dos meios de comunicação no nosso conhecimento. Em: Revista Brasileira de Comunicação. São Paulo: INTERCOM, vol. XVII, no. 02, 1994.

NÓVOA, Antonio. (org.) Profissão Professor. Porto, Portugal: Porto Editora, 1995. (Colecção Ciências da Educação)

NÓVOA, Antonio. Evidentemente: histórias da educação. 2a ${ }^{\text {a }}$ Ed. O Porto: Asa Editores, 2005.

OLIVEIRA-FORMOSINHO, J. Um capítulo metodológico: os estudos de caso. Em: KISHIMOTO, T. (org.). Formação e contexto: uma estratégia de intervenção. São Paulo: Pioneira Thomson Learning, 2002, p.89 a 108. 
OROZCO, Guillermo Gómez. Entre pantallas. Nuevos roles comunicativos de las audiências. Universidad de Guadalajara. Congresso da INTERCOM. Curitiba, Brasil, 2009.

OROZCO, Guillermo Gomez. Professores e meios de comunicação: desafios e estereótipos. Em: Revista Comunicação e Educação. No. 10. São Paulo, 1997.

OROZCO, Guillermo. Comunicação, educação e novas tecnologias: tríade do século XXI. Em: Educomunicação: construindo uma nova área do conhecimento. CITELli, Adilson e COSTA, M. C. Castilho. (orgs.). São Paulo: Paulinas, 2011. (Coleção Educomunicação)

PACHECO, J. A. B. Formação de professores: teoria e práxis. Minho: Instituto de Educação e Psicologia/Universidade de Minho, 1995.

PÉREZ GÓMEZ, Angél. A favor de la escuela educativa em la soiedad de la información y de la perplejidad. Em: SACRISTÁN, José Gimeno (compl.) La reforma necesaria: entre la política educativa y la práctica escolar.Madrid: Ediciones Morata, 2006.

PIMENTA, Selma Garrido. A análise crítica das contradições presentes na escola pode nos ajudar a transformá-la num espaço de formação ampliada. Em: COSTA, Marisa Vorraber (org.). A escola tem futuro? Rio de Janeiro: DP\&A, 2003.

PIMENTA, Selma Garrido. De professores, pesquisa e didática. Campinas, SP: Papirus, 2002. (Coleção Entre Nós Professores)

POPKEWITZ, Thomas S. Modelos de poder y regulación social em Pedagogia. Barcelona: Ediciones Pomares-Corredor, S.A., 1996.

POSTMAN, Neil. O desaparecimento da infância. Rio de Janeiro: Graphia, 1999. 
PRENSKY, Marc. Don't bother me, mom. I'm learning! [Não me aborreça, mãe. Estou estudando!]. St. Paul, Minnesota: Paragon House, 2006.

REZENDE E FUSARI, Maria Felisminda. Brincadeiras e brinquedos na TV para crianças: mobilizando opiniões de professores em formação inicial. Em: KISCHIMOTO, Tizuko. (org.) Jogo, brinquedo, brincadeira. São Paulo: Cortez, 1996.

REZENDE E FUSARI, Maria Felisminda. Meios de comunicação na formação de professores: televisão e vídeo em questão. São Paulo, 1990. Tese (Doutorado em Psicologia Escolar) Instituto de Psicologia, Universidade de São Paulo - USP.

REZENDE E FUSARI, Maria Felisminda. Multimídias e formação de professores e alunos: por uma produção social da comunicação escolar de cultura. São Paulo, FEUSP/ VII ENDIPE. Goiânia, 1994. (mimeo)

REZENDE E FUSARI. Mídias e formação de professores: em busca de caminhos de pesquisa vinculada à docência. Em: FAZENDA, Ivani. (org.). Novos enfoques da pesquisa educacional. São Paulo: Cortez, 1992.

ROCCO, Maria Thereza Fraga. Que pode a escola diante do fascínio da TV. Em: Multimeios aplicados à educação: Uma leitura critica. Revista Ideias. São Paulo: FDE, 1990, p. 53-62.

SACRISTÁN, José Gimeno. Consciência e acção sobre a prática como libertação profissional dos professores. Em: NÓVOA, Antonio. Profissão Professor. Porto, Portugal: Porto Editora, 1995. (Colecção Ciências da Educação)

SCHEIBE, Leda. O professor com futuro. Em: Perspectiva, no. 24: 169-171. Florianópolis, SC, 1995.

SILVA, Tomaz Tadeu da. Documentos de identidade: uma introdução às teorias do currículo. $3^{\text {a }}$. Edição. Belo Horizonte: Autêntica, 2011. 
SOARES, Ismar de Oliveira. Educomunicação: o conceito, o profissional, a aplicação: contribuições para a reforma do ensino médio. São Paulo: Paulinas, 2011.

SOARES, Ismar de Oliveira. Sociedade da informação ou da comunicação? São Paulo: Cidade Nova Editora, 1996.

SOUSA, Mauro Wilton de (org.). Sujeito, o lado oculto do receptor. São Paulo: Brasiliense, 1995.

SOUZA, Claudio Reynaldo Barbosa de. Complexidade e multirreferencialidade: opções educacionais ou caminhos inevitáveis? Em: IV Congresso de Pesquisa e Inovação da Rede Norte e Nordeste de Educação Tecnológica. Belém, 2009.

TEDESCO, J.C. Presentación. Em: OLIVEIRA, D.A. et al. Políticas educativas y territórios: modelos de articulación entre niveles de gobierno. Buenos Aires: UNESCO- IIPE, 2010.

TORRES, Rosa Maria. Tendências da formação docente nos anos 90. Em: WARDE, M.J. (org.). Novas Políticas educacionais: críticas e perspectivas. São Paulo: PUC, 1998.

TOSCHI, Mirza Seabra. Educação escolar e comunicação: presenças e ausências do jornal na sala de aula. Goiânia, 1993. Tese (mestrado em educação escolar brasileira). Faculdade de educação, Universidade federal de Goiás.

TOSCHI, Mirza Seabra. O professor e a comunicação: que professor é este? Em: PORTO, Tânia Maria Esperon (org.). Redes em construção: meios de comunicação e práticas educativas. Araraquara: JM Editora, 2003.

VEIGA NETO, Alfredo. Currículo, cultura e sociedade. Em: Educação Unisinos, vol. 5. No. 09, jul/dez, 2004, p.157-171. 
VEIGA, Cynthia Greive. História da educação. São Paulo: Ática, 2007.

VEIGA, I. P. A. Escola: espaço do projeto político-pedagógico. 4. ed. Campinas: Papirus, 1998.

VEIGA, I. P. A. Inovações e projeto-pedagógico: uma relação regulatória ou emancipatória? Caderno Cedes, v. 23, nº 61, Campinas, Dez, 2003.

VIANNA, Cláudia Pereira. O sexo e o gênero na docência. Cadernos Pagu (17/18), Campinas-SP, Núcleo de Estudos de Gênero-Pagu/Unicamp, 2001/02, pp.81-103.

VIRILIO, Paul. A velocidade de libertação. Lisboa. Relógio D’água, 2000.

VYGOTSKY, Lev Seminovich. A formação social da mente. São Paulo: Martins Fontes, 1984.

ZANCHETTA, Juvenal. Texto midiático e professores da escola básica. Anais da 31 ${ }^{\mathbf{a}}$. Reunião Anual da ANPED - Caxambu, Minas Gerais, 2008.

WOLF, Mauro. Teorias da comunicação. Lisboa: Presença, 1987. 


\section{BIBLIOGRAFIA CONSULTADA:}

BACCEGA, Maria Aparecida. A constituição do campo comunicação/educação. Revista Comunicação e Educação. São Paulo, [14]: 7-16, jan./abr. 1998.

BAUMAN, Zygmunt. Vida para consumo: a transformação das pessoas em mercadorias. Rio de Janeiro: Jorge Zahar Editora, 2008.

BELLONI, Maria Luíza e GOMES, Nilza Godoy. Infância, mídias e aprendizagem: autodidaxia e colaboração. Revista Educação e Sociedade. V.29, n. 104, out. 2008, p. 717-746.

BELLONI, Maria Luíza. Televisão como ferramenta pedagógica na formação de professores. Revista Educação e Pesquisa. Faculdade de Educação/USP. V.29, n.02, 2003. p. 287-301.

CITELLI, Adilson. Comunicação e educação: passagens e deslocamentos. Revista Comunicação e Educação. São Paulo: ECA-USP/Paulinas, n.01, jan./abr. 2010.

CITELLI, Adilson. Escola, linguagem e diversidade cultural nos contextos midiáticos. Revista Comunicação e Educação. São Paulo: ECA-USP/Paulinas, n.03, set./dez. 2007.

CORDEIRO, Sandro da Silva. Televisão em solo educativo: educando o olhar. Dissertação (mestrado). Universidade Federal do Rio Grande do Norte. Natal/RN, 2007.

FIGUEIREDO, Milene. Professor... As crianças já ligaram a TV. E você? Dissertação (mestrado). Universidade Federal de Santa Maria. Santa Maria/RS, 2007.

FISHER, Rosa Maria Bueno. O dispositivo pedagógico da mídia: modos de educar na (e pela) TV. Revista Educação e Pesquisa. Faculdade de Educação/USP. V. 28, n.01, 2002. 
FRANCO, Maria Amélia Santoro e PIMENTA, Selma Garrido. (orgs.). Didática: embates contemporâneos. São Paulo: Loyola, 2010.

GOMES, Lisandra. O cotidiano, as crianças, suas infâncias e a mídia. Revista Proposições. Campinas, V.19, n.03 (57), set./dez. 2008. p. 175-193.

GUIMARÃES, Glaucia. TV e Escola: discursos em confronto. São Paulo: Cortez, 2000.

KELLNER, Douglas e SHARE, Jeff. Educação para a leitura crítica da mídia, democracia radical e a reconstituição da educação. Revista Educação e Sociedade. Campinas, V.29, n. 104, out.2008. P. 687-715.

KENSKI, Vani Moreira. Educação e comunicação: interconexões e convergências. Revista Educação e Sociedade. Campinas, V. 29, n. 104, out.2008. p. 647-665.

LOURENÇO, Roberta Bezerra de Menezes Reiff. Aprendizagens da docência possibilitadas pela mediação de um processo de coordenação pedagógica construtivo-colaborativo, tendo a TV comercial como suporte para a formação de cidadãos críticos. Tese (doutorado). Universidade Federal de São Carlos. São Carlos/SP, 2004.

MAGALHÃES, Claudio. A inter-relação entre criança e TV. Revista Comunicação e Educação. São Paulo, (27): 38 a 45, maio/ago.2003.

MARTÍN-BARBERO, Jesús. Comunicação Plural: alteridade e sociabilidade. Revista Comunicação e Educação. São Paulo, [9]: 39-48, maio/ago. 1997.

MARTÍN-BARBERO, Jesús. Desafios culturais da comunicação à educação. Revista Comunicação e Educação. São Paulo, [18]: 51 a 61, maio/ago. 2000.

MOREIRA, Alberto da Silva. Cultura midiática e educação infantil. Revista Educação e Sociedade. Campinas, V.24, n.85, dez. 2003. p.1203-1235. 
OROZCO, Guillermo. Comunicação, educação e novas tecnologias: tríade do século XXI. Revista Comunicação e Educação. São Paulo, (23): 57 a 70, jan./abr. 2002.

OROZCO, Guillermo. Desafios da pesquisa em comunicação para o novo milênio. Revista Comunicação e Sociedade. Universidade Metodista de São Paulo. Edição 33, ano XVIII, 2000.

OROZCO, Guillermo. Professor e meios de comunicação: desafios, estereótipos. Revista Comunicação e Educação. São Paulo, [10]: 57-68, set./dez. 1997.

OROZCO, Guillermo. Teleaudiência: premissas para uma pedagogia. Revista Comunicação e Educação. São Paulo, [18]: 62 a 67, maio/ago. 2000.

PIMENTA, Selma Garrido (org.). Didática e formação de professores: percursos e perspectivas no Brasil e em Portugal. São Paulo: Cortez, 2000.

PORTO, Tânia Maria Esperon. Televisão e escola: escolas paralelas? Revista Comunicação e Educação. São Paulo, [4]: 25-30, set./dez. 1995.

QUINTÃO, Vânia Lúcia. Integração da TV na formação e prática do educador. Anais da 26a . Reunião Anual da ANPED. Caxambu, Minas Gerais, 2003.

SALGADO, Raquel; PEREIRA, Rita e SOUZA, Solange. Pela tela, pela janela: questões teóricas e práticas sobre infância e televisão. Caderno CEDES. Campinas, V.25, n.65, jan-abr, 2005.

SIQUEIRA, Juliana Maria de. Quem educará os educadores? A educomunicação e a formação de docentes em serviço. Dissertação (mestrado). Escola de Comunicações e Artes/USP. São Paulo, 2009.

SOARES, Ismar de Oliveira. Educomunicação/ educação: um campo de mediações. Revista Comunicação e Educação. São Paulo, [19]:12-24, set./dez. 2000. 
ZANCHETTA, Juvenal. Apontamentos para uma política educacional sobre mídia na escola brasileira. Revista Pro-posições. Campinas, V.19, n.01 (55), jan./abr. 2008. p. 141-158.

ZANCHETTA, Juvenal. Estudos sobre recepção midiática e educação no Brasil. Revista Educação e Sociedade. Campinas, v.28, n.101, set./dez. 2007. p. 1455-1475.

ZANCHETTA, Juvenal. Estudos sobre recepção midiática e educação no Brasil: percursos e considerações propositivas. Anais da 29a. Reunião Anual da ANPED Caxambu, Minas Gerais, 2006. 
ANEXOS 
ANEXO A - Matriz Curricular da Instituição UNILUS

\begin{tabular}{|c|c|c|}
\hline Disciplinas & $\begin{array}{c}\text { Carga } \\
\text { Horária } \\
\text { semanal }\end{array}$ & $\begin{array}{c}\text { Total da Carga } \\
\text { Horária }\end{array}$ \\
\hline Didática & 03 & 120 \\
\hline Psicologia da educacão & 02 & 80 \\
\hline Sociologia da Educação & 03 & 120 \\
\hline Políticas e organização da educação básica & 03 & 120 \\
\hline Comunicação, educação e tecnologias & 02 & 80 \\
\hline Filosofia da educação & 03 & 120 \\
\hline História da educação & 03 & 120 \\
\hline Leitura e produção de texto & 02 & 80 \\
\hline Currículo: teoria e prática & 02 & 80 \\
\hline Estudos estatísticos educacionais & 02 & 80 \\
\hline Fundamentos teóricos e aprendizagem & 02 & 80 \\
\hline Didática e pratica & 03 & 120 \\
\hline Políticas educacionais e educação de jovens e adultos & 02 & 80 \\
\hline Linguagem brasileira de sinais - LIBRAS & 02 & 80 \\
\hline Metodologia da pesquisa cientifica & 02 & 80 \\
\hline $\begin{array}{l}\text { Fundamentos teóricos e metodológicos da alfabetização e } \\
\text { práticas }\end{array}$ & 03 & 120 \\
\hline O lúdico e a brincadeira na educação infantil e práticas & 03 & 120 \\
\hline Linguagens e literatura infantil e práticas & 02 & 80 \\
\hline $\begin{array}{l}\text { Fundamentos históricos, políticos e legais da educação } \\
\text { infantil }\end{array}$ & 03 & 120 \\
\hline A arte na educação infantil e práticas & 02 & 80 \\
\hline $\begin{array}{l}\text { Fundamentos teóricos e metodológicos da Língua } \\
\text { portuguesa e práticas }\end{array}$ & 02 & 80 \\
\hline $\begin{array}{l}\text { Fundamentos teóricos e metodológicos de Ciências e } \\
\text { práticas }\end{array}$ & 02 & 80 \\
\hline $\begin{array}{l}\text { Fundamentos teóricos e metodológicos da Matemática e } \\
\text { práticas }\end{array}$ & 02 & 80 \\
\hline $\begin{array}{l}\text { Fundamentos teóricos e metodológicos da Historia e da } \\
\text { Geografia e práticas }\end{array}$ & 02 & 80 \\
\hline Fundamentos teóricos e metodológicos das Artes e práticas & 02 & 80 \\
\hline $\begin{array}{l}\text { Propostas metodológicas na alfabetização de jovens e } \\
\text { adultos e práticas }\end{array}$ & 03 & 120 \\
\hline Coordenação do trabalho pedagógico e práticas & 03 & 120 \\
\hline Gestão dos espaços educativos e práticas & 03 & 120 \\
\hline Planejamento educacional e práticas & 02 & 80 \\
\hline Avaliação institucional & 02 & 80 \\
\hline Trabalho de conclusão de curso & 02 & 80 \\
\hline
\end{tabular}




\section{ANEXO B - Matriz Curricular da Instituição UNIMES}

\begin{tabular}{|c|c|c|c|c|}
\hline Disciplinas & $\begin{array}{l}\text { C.H. } \\
\text { Teórica }\end{array}$ & $\begin{array}{c}\text { C.H.Práti } \\
\text { ca }\end{array}$ & $\begin{array}{l}\text { C.H. } \\
\text { Total }\end{array}$ & No. Aulas \\
\hline Comunicação & 40 & 0 & 40 & 2 \\
\hline Matemática & 64 & 16 & 80 & 4 \\
\hline Fundamentos da educação & 80 & 0 & 80 & 4 \\
\hline Tecnologias aplicadas à educação & 64 & 16 & 80 & 4 \\
\hline Linguagens e expressão da arte & 80 & 0 & 80 & 4 \\
\hline Leitura e produção de textos & 32 & 8 & 40 & 2 \\
\hline Filosofia da educação & 80 & 0 & 80 & 4 \\
\hline $\begin{array}{c}\text { Desenvolvimento da criança e do } \\
\text { adolescente }\end{array}$ & 80 & 0 & 80 & 4 \\
\hline História da educação & 40 & 0 & 40 & 2 \\
\hline Fundamentos da educação infantil & 80 & 0 & 80 & 4 \\
\hline Conhecimento lingüístico & 80 & 0 & 80 & 4 \\
\hline Psicologia da aprendizagem & 80 & 0 & 80 & 4 \\
\hline Pensamento pedagógico brasileiro & 80 & 0 & 80 & 4 \\
\hline $\begin{array}{c}\text { Políticas, legislação e organização da } \\
\text { educação básica }\end{array}$ & 80 & 0 & 80 & 4 \\
\hline Fundamentos e metodologia da Arte & 64 & 16 & 80 & 4 \\
\hline Didática e metodologias ativas & 64 & 16 & 80 & 4 \\
\hline Fundamentos da alfabetização & 32 & 8 & 40 & 2 \\
\hline $\begin{array}{l}\text { Fundamentos e metodologia de Língua } \\
\text { portuguesa }\end{array}$ & 64 & 16 & 80 & 4 \\
\hline $\begin{array}{l}\text { Fundamentos e metodologia de História e } \\
\text { geografia }\end{array}$ & 64 & 16 & 80 & 4 \\
\hline Conhecimento lógico-matemático & 32 & 8 & 40 & 2 \\
\hline $\begin{array}{c}\text { Fundamentos e metodologia de Ciências } \\
\text { naturais }\end{array}$ & 64 & 16 & 80 & 4 \\
\hline Natureza e sociedade & 40 & 0 & 40 & 2 \\
\hline
\end{tabular}




\section{ANEXO C - Matriz Curricular da Instituição UNIMONTE}

\begin{tabular}{|c|c|c|}
\hline & \multicolumn{2}{|l|}{ GRADE HORARIA } \\
\hline $\begin{array}{l}\text { Ciclo } \\
\text { modular }\end{array}$ & Módulo Disciplinas / Conteúdos & $\begin{array}{c}\text { CH } \\
\text { Total }\end{array}$ \\
\hline $1^{\mathrm{o}}$ & $1^{\circ}$ MóduloFilosofia e Educação & 80 \\
\hline $1^{\mathrm{o}}$ & 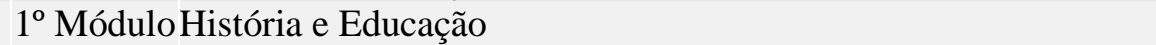 & 80 \\
\hline $1^{\mathrm{o}}$ & $1^{\circ}$ MóduloLeitura e Produção de Textos & 80 \\
\hline $1^{\circ}$ & $1^{\circ}$ MóduloMetodologia Científica & 80 \\
\hline $1^{\circ}$ & $1^{\circ}$ MóduloTrabalho Interdisciplinar Dirigido I & 80 \\
\hline \multicolumn{2}{|c|}{ Total de Horas / Aula no $1^{\circ}$ ciclo modular, $1^{\circ}$ módulo } & 400 \\
\hline $1^{\mathrm{o}}$ & $2^{\circ}$ MóduloEstatística Aplicada à Educação & 80 \\
\hline $1^{\circ}$ & $2^{\circ}$ MóduloEstudos da Ciência Política e Educação & 80 \\
\hline $1^{\circ}$ & $2^{\circ}$ MóduloPsicologia e Educação & 80 \\
\hline $1^{\circ}$ & $2^{\circ}$ Módulo Sociologia e Educação & 80 \\
\hline $1^{\mathrm{o}}$ & $2^{\circ}$ MóduloTrabalho Interdisciplinar Dirigido II & 80 \\
\hline \multicolumn{2}{|c|}{ Total de Horas / Aula no $1^{\circ}$ ciclo modular, $2^{\circ}$ módulo } & 400 \\
\hline $2^{\circ}$ & $3^{\circ}$ Módulo Antropologia e Educação & 80 \\
\hline $2^{\circ}$ & $3^{\circ}$ MóduloEstudo do Pensamento Educacional Brasileiro & 40 \\
\hline $2^{\circ}$ & 3º́nduloFilosofia da Diferença e Educação & 40 \\
\hline $2^{\circ}$ & $3^{\circ}$ MóduloPsicologia da Aprendizagem e do Desenvolvimento & 40 \\
\hline $2^{\circ}$ & $3^{\circ}$ MóduloTeoria e Prática Educativa Interdisciplinar & 80 \\
\hline $2^{\circ}$ & $3^{\circ}$ MóduloTrabalho Interdisciplinar Dirigido III & 80 \\
\hline \multicolumn{2}{|c|}{ Total de Horas / Aula no $2^{\circ}$ ciclo modular, $3^{\circ}$ módulo } & 360 \\
\hline $2^{\circ}$ & $4^{\circ}$ Módulo Avaliação e Planejamento Educacional & 40 \\
\hline $2^{\circ}$ & $4^{\circ}$ MóduloDidática e Prática de Ensino & 80 \\
\hline $2^{\circ}$ & $4^{\circ}$ MóduloOrganização do Sistema Educativo & 40 \\
\hline $2^{\circ}$ & $4^{\circ}$ Módulo Orientação de Estágio Curricular Superv: Gestão em Espaços & 112 \\
\hline $2^{\circ}$ & $4^{\circ}$ MóduloPolítica e Gestão Educacional & 80 \\
\hline $2^{\circ}$ & $4^{\circ}$ Módulo Trabalho Interdisciplinar Dirigido IV & 80 \\
\hline \multicolumn{2}{|c|}{ Total de Horas / Aula no $2^{\circ}$ ciclo modular, $4^{\circ}$ módulo } & 432 \\
\hline $2^{\circ}$ & $5^{\circ}$ MóduloCurrículo, Cultura e Sociedade & 80 \\
\hline $2^{\circ}$ & $5^{\circ}$ MóduloNecessidades Educativas Especiais & 60 \\
\hline $2^{\circ}$ & $5^{\circ}$ MóduloOrganização dos Tempos e dos Espaços Escolares & 40 \\
\hline $2^{\circ}$ & $\begin{array}{l}5^{\circ} \text { Módulo Orientação de Estágio Curricular Super.: Org. Tempos e Esp. } \\
\text { Escolares }\end{array}$ & 112 \\
\hline $2^{\circ}$ & $5^{\circ}$ MóduloProjeto de Extensão Comunitária & 160 \\
\hline $2^{\circ}$ & $5^{\circ}$ MóduloTrabalho e Educação & 80 \\
\hline \multicolumn{2}{|c|}{ Total de Horas / Aula no $2^{\circ}$ ciclo modular, $5^{\circ}$ módulo } & 532 \\
\hline $2^{\circ}$ & $6^{\circ}$ MóduloDiversidade Étnico-Cultural, Sexual e de Gênero & 40 \\
\hline $2^{\circ}$ & $6^{\circ}$ MóduloEducação de Jovens e Adultos - EJA & 80 \\
\hline $2^{\circ}$ & $6^{\circ}$ MóduloEducação e Sustentabilidade & 80 \\
\hline $2^{\circ}$ & $6^{\circ}$ MóduloFundamentos da Educação Infantil & 80 \\
\hline $2^{\circ}$ & $\begin{array}{l}6^{\circ} \text { Módulo Orientação de Estágio Curricular Super:Ciclos de Vida em Esp. } \\
\text { Escol }\end{array}$ & 112 \\
\hline \multicolumn{2}{|c|}{ Total de Horas / Aula no $2^{\circ}$ ciclo modular, $6^{\circ}$ módulo } & 392 \\
\hline $3^{\circ}$ & $7^{\circ}$ Módulo Alfabetização e Letramento & 80 \\
\hline $3^{\circ}$ & $7^{\circ}$ Módulo Arte, Música, Corpo e Movimento & 80 \\
\hline $3^{\circ}$ & $7^{\circ}$ MóduloMetodologia do Ensino de Ciências & 40 \\
\hline
\end{tabular}


\begin{tabular}{ll|l}
$3^{\circ}$ & $7^{\circ}$ MóduloMetodologia do Ensino de Educação Física & 40
\end{tabular}

\begin{tabular}{ll|l}
$3^{\circ}$ & $7^{\circ}$ MóduloMetodologia do Ensino de Matemática & 40
\end{tabular}

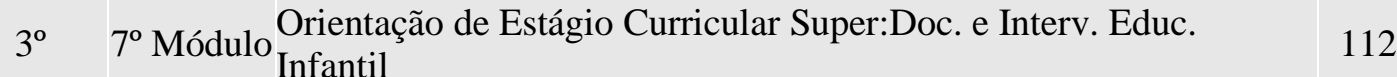

$3^{\circ} \quad 7^{\circ}$ Módulo TCC: Aprovação Projeto de Monografia ou de Artigo Acadêmico 112

Total de Horas / Aula no $3^{\circ}$ ciclo modular, $7^{\circ}$ módulo $\quad 512$

\begin{tabular}{ll|l}
$3^{\circ}$ & $8^{\circ}$ MóduloEducação e Tecnologias & 80
\end{tabular}

$\begin{array}{lll}3^{\circ} \quad 8^{\circ} \text { MóduloLíngua Brasileira de Sinais - LIBRAS } & 80\end{array}$

$\begin{array}{lll}3^{\circ} & 8^{\circ} \text { Módulo Metodologia de Ensino da Língua Portuguesa } & 80\end{array}$

$\begin{array}{lll}3^{\circ} & 8^{\circ} \text { MóduloMetodologia do Ensino de Geografia } & 40\end{array}$

\begin{tabular}{ll|l}
$3^{\circ}$ & $8^{\circ}$ MóduloMetodologia do Ensino de História & 40
\end{tabular}

$3^{\circ} \quad 8^{\circ}$ Módulo Orientação de Estág Cur Superv:Doc. e Interv.no Ens. Fund. (REG 112

\begin{tabular}{ll|l}
$3^{\circ} \quad 8^{\circ}$ Módulo \\
Acadêmico
\end{tabular}

Total de Horas / Aula no $3^{\circ}$ ciclo modular, $8^{\circ}$ módulo $\quad \mathbf{5 6 0}$ 


\section{ANEXO D - Matriz Curricular da Instituição UNIP}

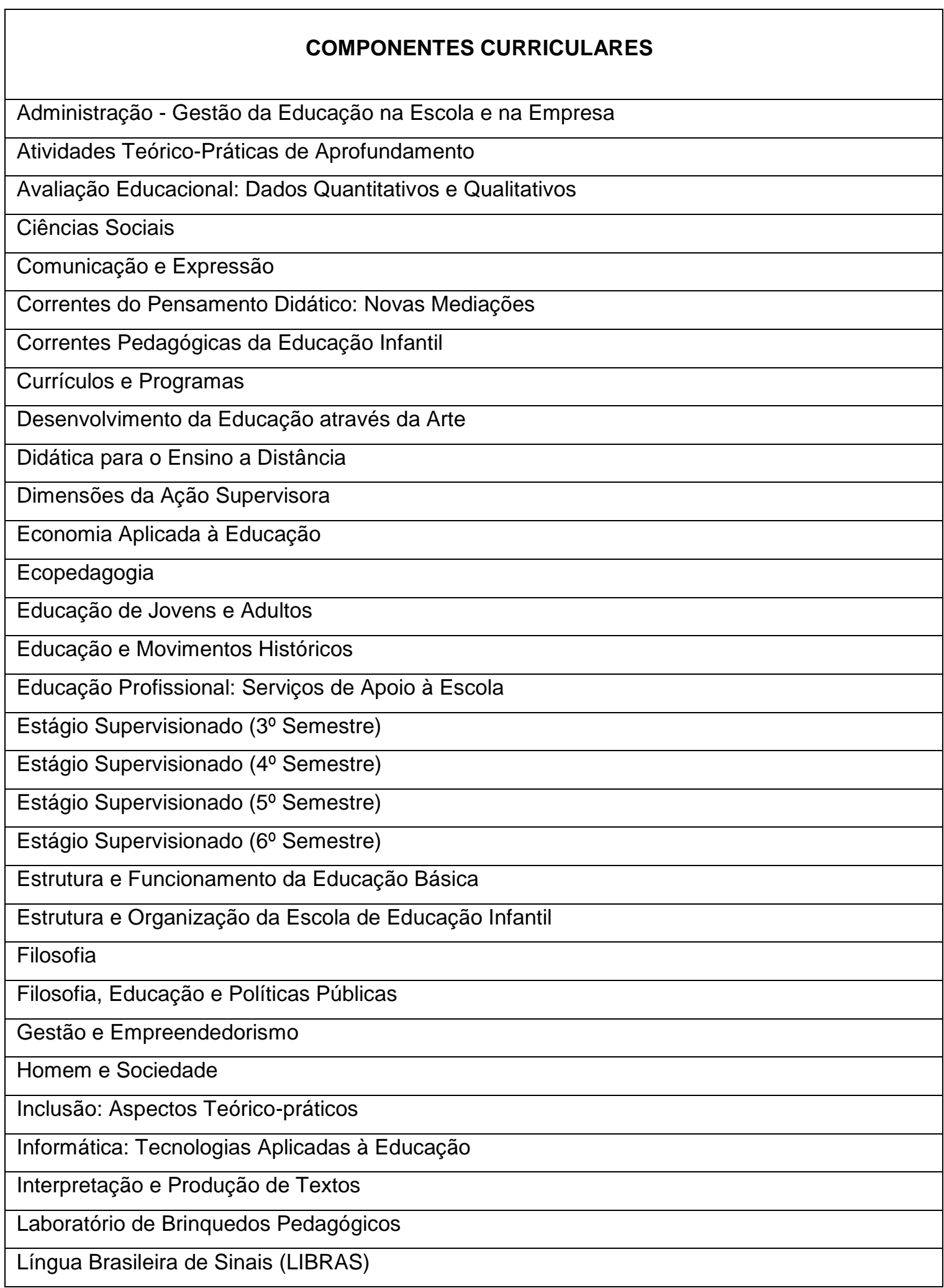




\begin{tabular}{|l|}
\hline Metodologia da Alfabetização e da Língua Portuguesa \\
\hline Metodologia de Ensino na Educação Básica \\
\hline Metodologia do Ensino de História, Geografia, Artes e Educação Física \\
\hline Metodologia do Ensino de Matemática e de Ciências \\
\hline Metodologia do Trabalho Acadêmico \\
\hline Métodos de Pesquisa \\
\hline O Jogo na Construção do Conhecimento \\
\hline Orientação Educacional: mediação Escola, Família e Saúde \\
\hline Orientação Educacional: mediação Escola, Trabalho e Lazer \\
\hline Política Social em Saúde \\
\hline Práticas de Gestão e Resultados \\
\hline Prática de Gestão em Escolas e Empresas \\
\hline Práticas e Projetos de Orientação Educacional \\
\hline Prática e Projetos do Ensino Fundamental \\
\hline Prática e Projetos em Supervisão Escolar \\
\hline Prática na 1ã Infância (0 a 3 anos) \\
\hline Práticas e projetos na Educação Infantil \\
\hline Projetos De Ação Pedagógica e Planejamento Educacional \\
\hline Problemas Sociais e Educação \\
\hline Psicologia do Desenvolvimento: ciclo vital \\
\hline Psicologia Construtivista e Sócio-Interacionista \\
\hline Psicologia do Desenvolvimento e Teorias de Aprendizagem \\
\hline Reflexões Filosóficas: Ética, Comunicação e Marketing \\
\hline
\end{tabular}




\section{ANEXO E - Matriz Curricular da Instituição UNISANTA}

\section{Matriz Curricular}

\section{0 semestre}

Filosofia da Educação I

História da Educação I

Leitura e Produção de Textos I

Educação e Tecnologias I

Metodologia da Pesquisa em Educação

Educação Infantil I

Projeto Multidisciplinar Pedagógico I

Sociologia e Antropologia da Educação I

Organização dos Sistemas de Ensino I

Atividades Complementares

\section{2ำ semestre}

Filosofia da Educação II

História da Educação II

Leitura e Produção de Textos II

Educação e Tecnologias II

Psicologia da Educação I

Educação Infantil II

Projeto Multidisciplinar Pedagógico II

Sociologia e Antropologia da Educação II

Organização dos Sistemas de Ensino II

Atividades Complementares

\section{3ำ semestre}

Psicologia da Educação II

Didática I

Avaliação da Aprendizagem

Prática Docente na Educação Infantil

Legislação e Políticas Públicas

Eletiva I

Projeto Multidisciplinar Pedagógico III

Alfabetização e Letramento I

Organização do Trabalho na Educação Infantil

Atividades Complementares

\section{$4^{\circ}$ semestre}

Didática I

Projetos na Educação Infantil

Oficina de /recreação e Jogos

Metodologia do Ensino de Arte

Legislação e Políticas Públicas II

Eletiva II

Projeto Multidisciplinar Pedagógico II

Alfabetização e Letramento II

Educação Especial e Inclusiva I

Atividades Complementares

Estágio Supervisionado em /educação Infantil

\section{5 semestre}

Metodologia do Ensino da Víngua Portuguesa I

Metodologia do /ensino da Matemática I

Metodologia do Ensino da História I

Metodologia do Ensino da Geografia I 
Metodologia do Ensino da Ciência I

Eletiva III

Projeto Multidisciplinar Pedagógico V

Educação de Jovens e Adultos I

Educação Especial e Inclusiva II

Atividades Complementares

Estágio Supervisionado nos Anos Iniciais do Ensino Fundamental

\section{6을 semestre}

Metodologia do Ensino da Língua Portuguesa II

Metodologia do /ensino da Matemática II

Metodologia do Ensino da História II

Metodologia do Ensino da Geografia II

Metodologia do Ensino da Ciência II

Educação das Relações Étnico Raciais

Projeto Multidisciplinar Pedagógico VI

Educação de Jovens e Adultos II

Pesqu7isa e Prática nos AIEF

Atividades Complementares

Estágio Supervisionado nos Anos Inicia do Ensino Fundamental

।

\section{$7^{\circ}$ semestre}

Gestão e Planejamento da /educação Básica

Gestão Educacional I

Planejamento, /execução e Avaliação do Projeto Pedagógico

Supervisão e Coordenação Pedagógico

Escola e Currículo

Trabalho de Conclusão de Curso I

Projeto Multidisciplinar Pedagógico VII

Educação e Ética Profissional

Eletiva IV

Atividades Complementares

Estágio Supervisionado nos Anos Iniciais do Ensino Fundamental

\section{$8^{\circ}$ semestre}

Pedagogia em Ambientes não Escolares

Gestão e Planejamento de Espaços Educativos

Práticas de Ensino em Matérias Pedagógicas (M-EM)

Educação não Escolar: Práticas Sociais e Diversidade Cultural

Trabalho de Conclusão de Curso II

LIBRAS

Temas Atuais em Educação

Eletiva $\mathrm{V}$

Estágio Supervisionado nos Anos Iniciais do Ensino Fundamental

Disciplinas Eletivas:

Oficina de Materiais Pedagógicos

Laboratório Lúdico

Projetos para Espaços Educativos

Psicopedagogia

Gestão de Pessoas

Estatística Aplicada à Educação

Educação, Responsabilidade Social em Espaços Educativos

História da Infância e Direitos Educativos

Avaliação Institucional

História da Idéias Pedagógicas

Educação, Ética e Cidadania 


\section{ANEXO F - Matriz Curricular da Instituição UNISANTOS}

\section{1올 semestre}

Filosofia da Educação I

História da Educação I

Leitura e Produção de Textos I

Educação e Tecnologias I

Metodologia da Pesquisa em Educação

Educação Infantil I

Projeto Multidisciplinar Pedagógico I

Sociologia e Antropologia da Educação I

Organização dos Sistemas de Ensino I

Atividades Complementares

\section{2 o semestre}

Filosofia da Educação II

História da Educação II

Leitura e Produção de Textos II

Educação e Tecnologias II

Psicologia da Educação I

Educação Infantil II

Projeto Multidisciplinar Pedagógico II

Sociologia e Antropologia da Educação II

Organização dos Sistemas de Ensino II

Atividades Complementares

\section{3 o semestre}

Psicologia da Educação II

Didática I

Avaliação da Aprendizagem

Prática Docente na Educação Infantil

Legislação e Políticas Públicas

Eletiva I

Projeto Multidisciplinar Pedagógico III

Alfabetização e Letramento I

Organização do Trabalho na Educação Infantil

Atividades Complementares

\section{$4^{\circ}$ semestre}

Didática I

Projetos na Educação Infantil

Oficina de /recreação e Jogos

Metodologia do Ensino de Arte

Legislação e |Políticas Públicas ||

Eletiva II

Projeto Multidisciplinar Pedagógico II

Alfabetização e Letramento II

Educação Especial e Inclusiva I

Atividades Complementares

Estágio Supervisionado em /educação Infantil

\section{5 semestre}

Metodologia do Ensino da língua Portuguesa I

Metodologia do /ensino da Matemática I

Metodologia do Ensino da História I

Metodologia do Ensino da Geografia I

Metodologia do Ensino da Ciência I

Eletiva III

Projeto Multidisciplinar Pedagógico V 
Educação de Jovens e Adultos I

Educação Especial e Inclusiva II

Atividades Complementares

Estágio Supervisionado nos Anos Iniciais do Ensino Fundamental

\section{6ㅇ semestre}

Metodologia do Ensino da Língua Portuguesa II

Metodologia do /ensino da Matemática II

Metodologia do Ensino da História II

Metodologia do Ensino da Geografia II

Metodologia do Ensino da Ciência II

Educação das Relações Étnico Raciais

Projeto Multidisciplinar Pedagógico VI

Educação de Jovens e Adultos II

Pesqu7isa e Prática nos AIEF

Atividades Complementares

Estágio Supervisionado nos Anos Inicia do Ensino Fundamental

।

\section{$7^{\circ}$ semestre}

Gestão e Planejamento da educação Básica

Gestão Educacional I

Planejamento, /execução e Avaliação do Projeto Pedagógico

Supervisão e Coordenação Pedagógico

Escola e Currículo

Trabalho de Conclusão de Curso I

Projeto Multidisciplinar Pedagógico VII

Educação e Ética Profissional

Eletiva IV

Atividades Complementares

Estágio Supervisionado nos Anos Iniciais do Ensino Fundamental

\section{8 o semestre}

Pedagogia em Ambientes não Escolares

Gestão e Planejamento de Espaços Educativos

Práticas de Ensino em Matérias Pedagógicas (M-EM)

Educação não Escolar: Práticas Sociais e Diversidade Cultural

Trabalho de Conclusão de Curso II

LIBRAS

Temas Atuais em Educação

Eletiva V

Estágio Supervisionado nos Anos Iniciais do Ensino Fundamental

Disciplinas Eletivas:

Oficina de Materiais Pedagógicos

Laboratório Lúdico

Projetos para Espaços Educativos

Psicopedagogia

Gestão de Pessoas

Estatística Aplicada à Educação

Educação, Responsabilidade Social em Espaços Educativos

História da Infância e Direitos Educativos

Avaliação Institucional

História da Idéias Pedagógicas

Educação, Ética e Cidadania 
APÊNDICE - Questionário aplicado aos docentes da Rede Municipal de Ensino de Santos
1. Qual sua faixa etária?
( ) entre 20 e 25 anos
( ) entre 26 e 30 anos
( ) entre 31 e 40 anos
( ) mais de 40 anos

\section{Qual seu sexo?}

( ) feminino

( ) masculino

3. Onde você se formou?
( ) Unisantos
( ) Unisanta
( ) Unimes
( ) Unip
( ) Unimonte
( ) Unilus
( ) Outra instituição. Qual?
4. Em qual curso?
( ) Pedagogia
( ) Letras
( ) Matemática
( ) Historia
( ) Ciências
( ) Outro. Qual?

5. Há quanto tempo você esta formada (o)?
( ) menos de um ano
( ) entre um e três anos
( ) de três a cinco anos 
( ) de cinco a dez anos

( ) há mais de dez anos

6. Em seu curso você estudou quais dessas disciplinas?

( ) Didática

( ) Metodologia de Ensino

( ) Tecnologia e Educação

( ) Sociologia

( ) Historia da Educação

( ) Informática

( ) Diversidade Cultural

( ) Alfabetização e Letramento

7. Você leciona para qual ano?
( ) 1ㅇ Ano
( ) 2ㅇ Ano
( ) 3으 Ano
( ) 4 읏 Ano
( ) 5o Ano

8. Em suas aulas você costuma usar quais dos seguintes recursos e/ou materiais:

\begin{tabular}{|l|l|l|l|l|l|l|}
\hline Nunca & $\begin{array}{c}\text { Toda } \\
\text { aula }\end{array}$ & $\begin{array}{c}\text { Duas a três vezes por } \\
\text { semana }\end{array}$ & $\begin{array}{c}\text { Uma vez } \\
\text { por } \\
\text { semana }\end{array}$ & $\begin{array}{c}\text { Uma vez } \\
\text { por mês }\end{array}$ & $\begin{array}{c}\text { Outra } \\
\text { periodicidade } \\
\text { Qual? }\end{array}$ \\
\hline $\begin{array}{l}\text { Gibis/histórias } \\
\text { em } \\
\text { quadrinhos }\end{array}$ & & & & & & \\
\hline Músicas & & & & & & \\
\hline $\begin{array}{l}\text { Lousa } \\
\text { TV: } \\
\text { telenovelas, } \\
\text { desenhos, } \\
\text { comerciais }\end{array}$ & & & & & & \\
\hline
\end{tabular}




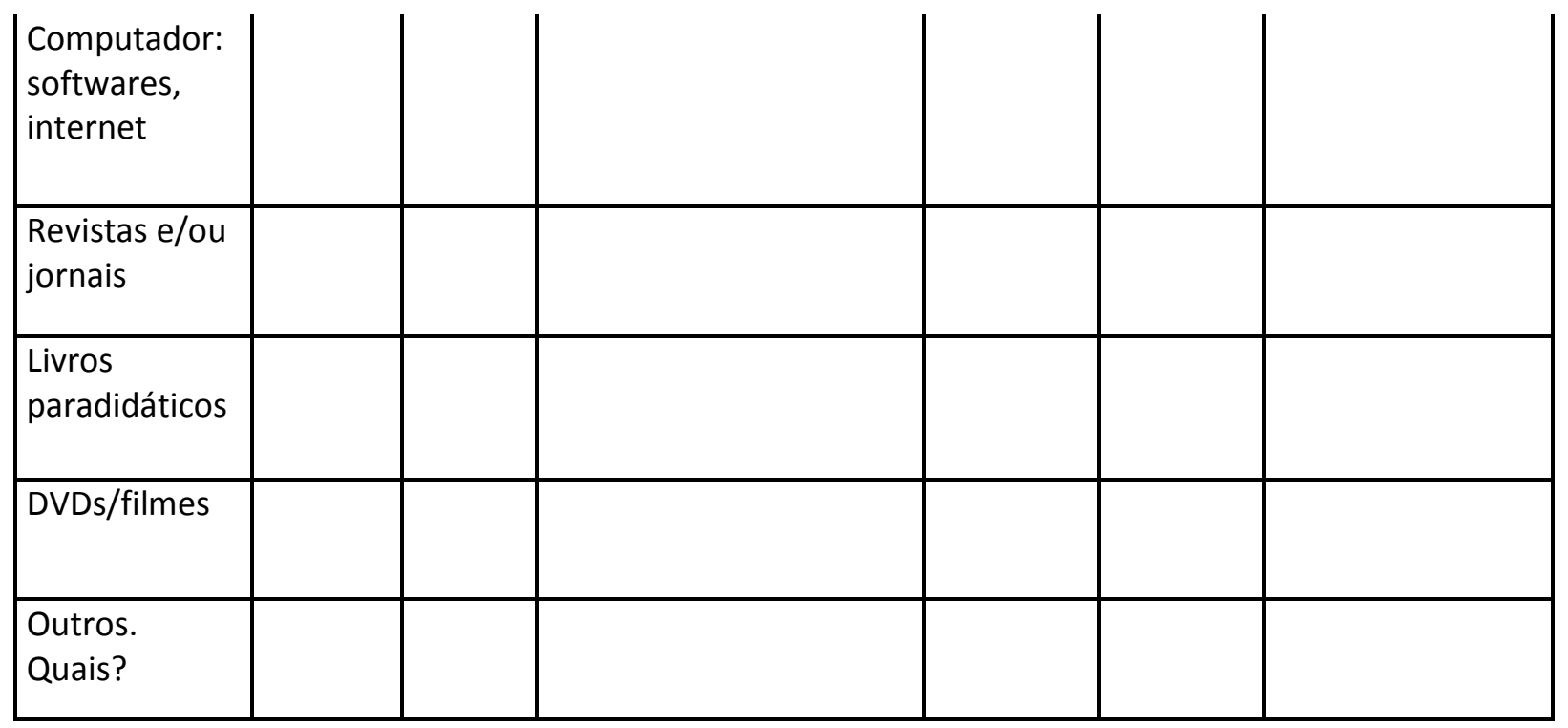

9. Por que você utiliza esses materiais e/ou recursos em aula?

10. Você acredita que a utilização de programas de TV pode colaborar com suas aulas?

11. Nas suas aulas você tem por hábito sondar quais programas televisivos seus alunos assistem?
( ) sim
( ) não
( ) às vezes

Se a resposta for sim ou às vezes, você discute com eles a programação assistida?

12. Você se sente preparado para o trabalho com mídias, tais como TV e computador? Explique sua resposta. 
13. Como você entende a relação entre mídias - TV e computador - e o trabalho com educação? 